\title{
Release of Dried Radioactive Waste Materials Technical Basis Document
}

\section{S. D. Kozlowski}

CH2MHILL Hanford Group, Inc.

Richland, WA 99352

U.S. Department of Energy Contract DE-AC27-99RL14047

$\begin{array}{lll}\text { EDT/ECN: } & 723091 \mathrm{R} 1 & \text { UC: N/A } \\ \text { Cost Center: } & 7 \mathrm{G} 500 & \text { Charge Code: } 501027 \\ \text { B\&R Code: } & \text { N/A } & \text { Total Pages: / lele }\end{array}$

Key Words: Demonstration Bulk Vitrification System, DBVS, Dried Waste Release, Dried Waste

Abstract: This Technical Basis Report supports the accident analysis associated with the release of dried waste from the Demonstration Bulk Vitrification System and reflects the design basis of July, 2006.

TRADEMARK DISCLAIMER. Reference herein to any specific commercial product, process, or service by trade name, trademark, manufacturer, or otherwise, does not necessarily constitute or imply its endorsement, recommendation, or favoring by the United States Government or any agency thereof or its contractors or subcontractors.

Printed in the United States of America. To obtain copies of this document, contact: Document Control Services, P.O. Box 950, Mailstop H6-08, Richland WA 99352, Phone (509) 372-2420; Fax (509) 376-4989.
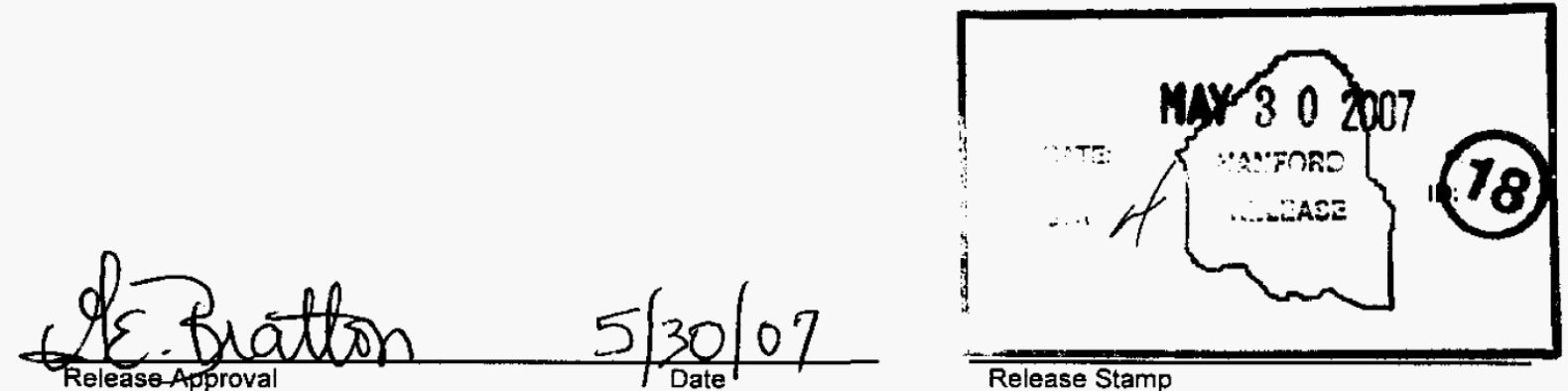

\section{Approved For Public Release}




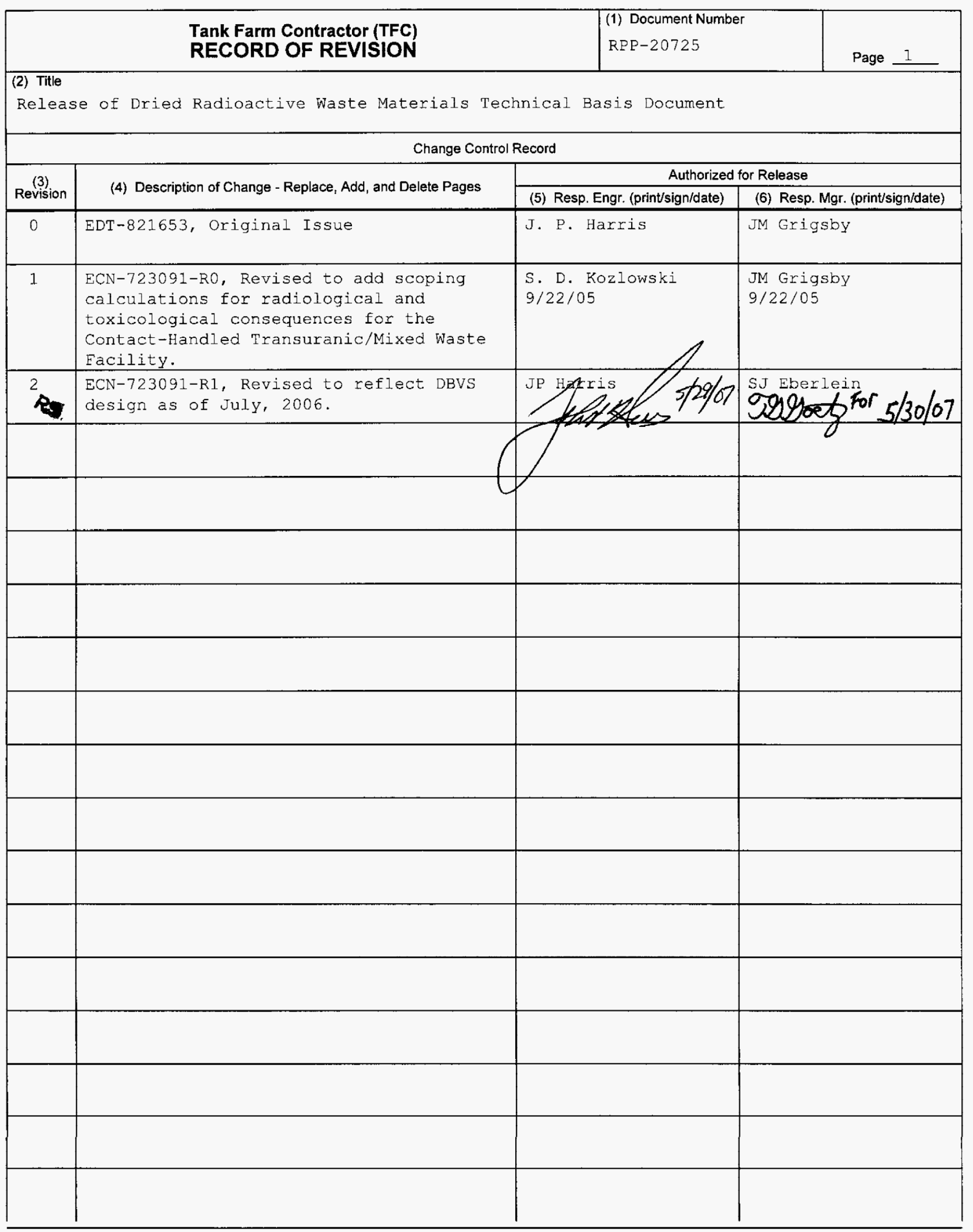

A-6003-835 (05/04) 


\section{CONTENTS}

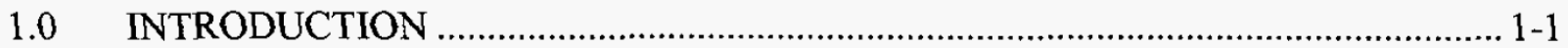

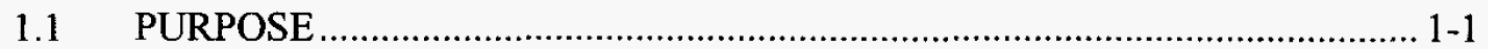

1.2 BACKGROUND INFORMATION …....................................................... 1-1

1.2.1 Representative Accidents .............................................................. 1-1

1.2.2 Bounding Offsite Accident .............................................................. 1-5

1.2.3 Associated Hazardous Conditions .................................................. 1-6

1.3 RISK BINNING METHODOLOGY …...................................................... 1-6

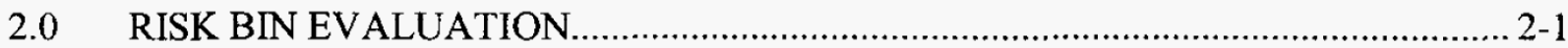

$2.1 \quad$ RELEASE OF DRIED WASTE

2.1.1 Representative Accident 1: Release of Dried Waste During Pneumatic Transfer ...................................................................... 2-2

2.1.2 Release of Dried Waste (Height Greater than $3 \mathrm{~m}$ ) Due to Small Fire-Induced Dryer Superstructure Failure and Subsequent Waste Dryer Collapse ..................................................................................... 2-8

2.1.3 Representative Accident 2: Spills and Falls of Dried Waste from Beneath the Waste Dryer Outlet (Greater Than 3 m Spill).................... 2-9

2.1.4 Lid Fails to Seal to the In-Container Vitrification Container Due to Misalignment or Sealing Lip Damage ................................................ 2-16

2.1.5 Drop and Spill of Dried Waste From ICV Container Due to Interrupted Melt (Less Than $3 \mathrm{~m}$ High) ................................................ 2-16

2.2 FILTRATION FAILURE SCENARIOS .................................................. 2-22

2.2.1 Representative Accident 3: Filter Failure Due to High Temperature ................................................................................... 2-22

2.2.2 Filter Failure Due to High Pressure …........................................... 2-29

2.2.3 Eight-hour Unfiltered Release .................................................... 2-30

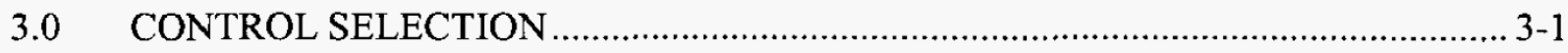

3.1 SELECTED CONTROLS FOR THE RELEASE OF DRIED

RADIOACTIVE WASTE ACCIDENTS .................................................... 3-1

3.1.1 Control Selection ...................................................................... 3-1

3.1.2 Selected Control Strategies ......................................................... 3-2

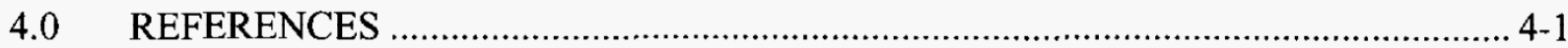


RPP-20725 REV 2

\section{APPENDICES}

A RISK BINNING/CONTROL ALLOCATION MEETING ATTENDEES................... A-i

B SUPPORTING CALCULATIONS ..................................................................... B-i

C PEER REVIEW CHECKLISTS FOR THE DEMONSTRATION BULK VITRIFICATION SYSTEM .............................................................................. C-i

D CONTACT-HANDLED TRANSURANIC MIXED WASTE PACKAGING UNIT FACILITY ANALYSIS ....................................................................... D-i

E CONTACT-HANDLED TRANSURANIC MIXED WASTE RISK BINNING/CONTROL ALLOCATION MEETING ATTENDEES ..................................

F SUPPORTING CALCULATIONS FOR THE DRIED WASTE RELEASE ACCIDENT AT THE CONTACT-HANDLED TRANSURANIC MIXED WASTE PACKAGING UNIT. F-i

G HUMAN FACTORS EVALUATION AND PEER REVIEW CHECKLISTS FOR THE CONTACT-HANDLED TRANSURANIC MIXED WASTE PACKAGING UNIT G-i

\section{LIST OF FIGURES}

Figure 1-1. Demonstration Bulk Vitrification System Process Summary ............................ 1-2

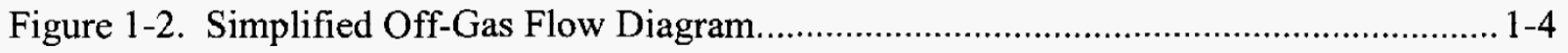

\section{LIST OF TABLES}

Table 1-1. Offsite (Toxicological Only) Risk Bins. ...................................................... 1-7

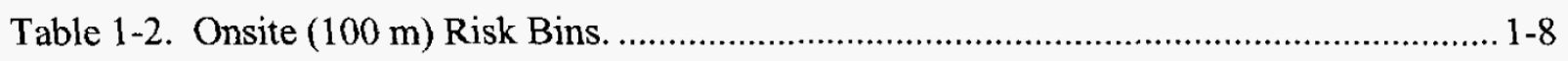

Table 1-3. Environmental Consequence Categories....................................................... 1-8

Table 2-1. Risk Binning Results for Dried Waste Releases ................................................. 2-1

Table 2-2. Qualitative Evaluation of Analysis Assumptions for a Release of Dried Waste During Pneumatic Transfer 


\section{RPP-20725 REV 2}

Table 2-3. Summary of Onsite Radiological Consequences Without Controls for the Release of Dried Radioactive Waste During Pneumatic Transport.

Table 2-4. Summary of Toxicological Consequences Without Controls for the Release of Dried Radioactive Waste during Pneumatic Transport.

Table 2-5. Qualitative Evaluation of Analysis Assumptions for a Release of Dried Waste from beneath the Waste Dryer Outlet (Greater Than $3 \mathrm{~m}$ High).

Table 2-6. Summary of Onsite Radiological Consequences Without Controls for the Spill of Dried Waste from Beneath the Waste Dryer Outlet (Greater Than $3 \mathrm{~m} \mathrm{High}$ ).

Table 2-7. Summary of Toxicological Consequences Without Controls for the Spill of Dried Waste from Beneath the Waste Dryer Outlet (Greater Than $3 \mathrm{~m}$ High)...... 2-15

Table 2-8. Qualitative Evaluation of Analysis Assumptions for a Release of Dried Waste Spills and Falls from In-Container Vitrification Container after Interrupted Melt (Less Than $3 \mathrm{~m}$ High)

Table 2-9. Summary of Onsite Radiological Consequences Without Controls for the Spill of Dried Waste from In-Container Vitrification Container (Less Than $3 \mathrm{~m}$ High).

Table 2-10. Summary of Toxicological Consequences Without Controls for the Spill of Dried Waste from In-Container Vitrification Container (Less Than $3 \mathrm{~m}$ High).

Table 2-11. Risk Binning Results for Dried Waste Releases Due to Filtration Failures.

Table 2-12. Qualitative Evaluation of Analysis Assumptions for a Release of Dried Waste Due to Filtration Failures

Table 2-13. Summary of Onsite Radiological Consequences Without Controls for the Filtration Failure Representative Accident.

Table 2-14. Summary of Toxicological Consequences Without Controls for the Filtration Failure Representative Accident. 


\section{LIST OF TERMS}

AA

AWTE

BBI

CH-TRUM

CWC

DBVS

DST

DWTS

ETF

ERPG

HEGA

HEPA

ICV

IDF

ISO

LERF

MAR

OGTS

PDSA

RF

SCR

SOF

SSC

SST

TEDF

TEEL

TSR

ULD

WPU analysis assumption

Ancillary Waste Transfer Enclosure

Best-Basis Inventory

Contact-Handled Transuranic Mixed (Waste)

Central Waste Complex

Demonstration Bulk Vitrification System

double-shell tank

Dried Waste Transfer System

Effluent Treatment Facility

Emergency Response Planning Guideline

high-efficiency gas absorber

high-efficiency particulate air (filter)

In-Container Vitrification

Integrated Disposal Facility

International Organization for Standardization

Liquid Effluent Treatment Facility

material at risk

Off-Gas Treatment System

preliminary documented safety analysis (RPP-23429, Preliminary

Documented Safety Analysis for the Demonstration Bulk

Vitrification System)

respirable fraction

selective catalytic reduction (unit)

sum of fractions

structures, systems, and components

single-shell tank

Treated Effluent Disposal Facility

Temporary Emergency Exposure Limit

technical safety requirement

unit-liter dose

Waste Packaging Unit 


\subsection{INTRODUCTION}

\subsection{PURPOSE}

This technical basis document was developed to support RPP-23429, Preliminary Documented Safety Analysis for the Demonstration Bulk Vitrification System (PDSA) and RPP-23479, Preliminary Documented Safety Analysis for the Contact-Handled Transuranic Mixed (CH-TRUM) Waste Facility. The main document describes the risk binning process and the technical basis for assigning risk bins to the representative accidents involving the release of dried radioactive waste materials from the Demonstration Bulk Vitrification System (DBVS) and to the associated represented hazardous conditions. Appendices $\mathrm{D}$ through $\mathrm{F}$ provide the technical basis for assigning risk bins to the representative dried waste release accident and associated represented hazardous conditions for the Contact-Handled Transuranic Mixed (CH-TRUM) Waste Packaging Unit (WPU).

The risk binning process uses an evaluation of the frequency and consequence of a given representative accident or represented hazardous condition to determine the need for safety structures, systems, and components (SSC) and technical safety requirement (TSR)-level controls. A representative accident or a represented hazardous condition is assigned to a risk bin based on the potential radiological and toxicological consequences to the public and the collocated worker. Note that the risk binning process is not applied to facility workers because credible hazardous conditions with the potential for significant facility worker consequences are considered for safety-significant SSCs and/or TSR-level controls regardless of their estimated frequency. The controls for protection of the facility workers are described in RPP-23429 and RPP-23479.

Determination of the need for safety-class SSCs was performed in accordance with DOE-STD-3009-94, Preparation Guide for U.S. Department of Energy Nonreactor Nuclear Facility Documented Safety Analyses, as described below.

\subsection{BACKGROUND INFORMATION}

\subsubsection{Representative Accidents}

The DBVS will receive, process and package waste retrieved from single-shell tank (SST) 241-S-109, located in the 200 West Area. The Waste Retrieval System will retrieve saltcake waste from the tank, pretreat the waste through selective dissolution and solid/liquid separation, and deliver the waste salt solution to the DBVS. The DBVS will combine the waste salt solution with glass formers and clean soil, vitrify the salt/glass former mixture and produce a vitrified waste package suitable for disposal in an onsite licensed disposal facility. Figure 1-1 summarizes the demonstration bulk vitrification process. 
Figure 1-1. Demonstration Bulk Vitrification System Process Summary.

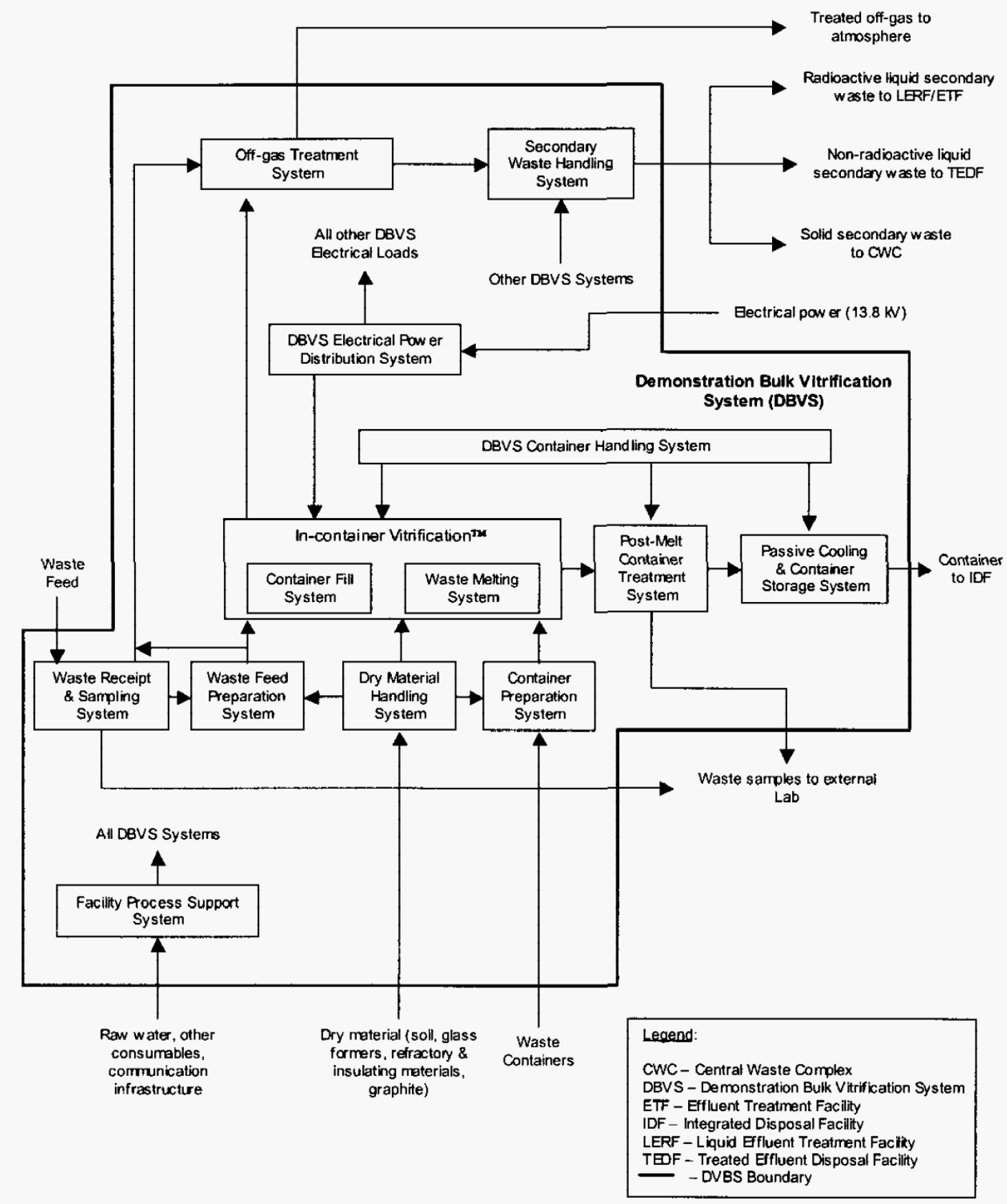

The salt waste solution will be transferred to a waste dryer where it will be mixed with soil and small amounts of zirconium dioxide $\left(\mathrm{ZrO}_{2}\right)$ and boric oxide $\left(\mathrm{B}_{2} \mathrm{O}_{3}\right)$ and dried by evaporation to approximately $1 \mathrm{wt} \%$ moisture. The dryer product is pneumatically conveyed to one of two dried waste receivers located directly above the melt station. The water vapor, gases, and dust generated by the mixing and drying processes will be routed to the Off-Gas Treatment System (OGTS). 
An In-Container Vitrification (ICV) ${ }^{1}$ container will be prepared on site by lining it with insulating boards, silica sand, and refractory panels; placing a starter path layer at the bottom of the container; and installing the container lid and two electrodes. The container will then be moved into place in the melt station and connected to the power supply, feed chutes, instrumentation and the OGTS.

The dried mixture will be fed from the dried waste receivers into the ICV container by means of rotary valves. Joule heating will melt the mixture to produce borosilicate glass. The air space in the ICV container will be exhausted to the OGTS.

The OGTS shown in Figure 1-2 will treat the overhead gases from both the waste dryer and the ICV container. Components of the OGTS will condense the water vapor in the gases, and will remove particulates, acid gases, radionuclides, and toxic chemicals so that the effluent gases will meet environmental emission standards.

The DBVS off-gas treatment filtration system consists of a condenser, a mist eliminator, a heater (to lower the relative humidity of the air stream), and two parallel filter trains, each containing a prefilter and two $2 \mathrm{ft}$ by $2 \mathrm{ft}$ by $1 \mathrm{ft}$ thick high-efficiency particulate air (HEPA) filters in series. The HEPA filters are intended to trap any particulate material coming out of the DBVS OGTS. After passing through the HEPA filter system, the off-gas passes through an activated carbon filter. The purpose of the carbon filter is to trap any chemically active gaseous material, primarily ${ }^{129} \mathrm{I}$, coming out of the OGTS. Downstream of the carbon filter is a final off-gas polishing filter.

The entire filtration system is designed to handle the OGTS effluent from the entire vitrification campaign, i.e., the loading and vitrification of approximately 50 containers of waste.

\footnotetext{
${ }^{1}$ ICV TM (In Container Vitrification) is a trademark of AMEC Inc., London, England.
} 
RPP-20725 REV 2

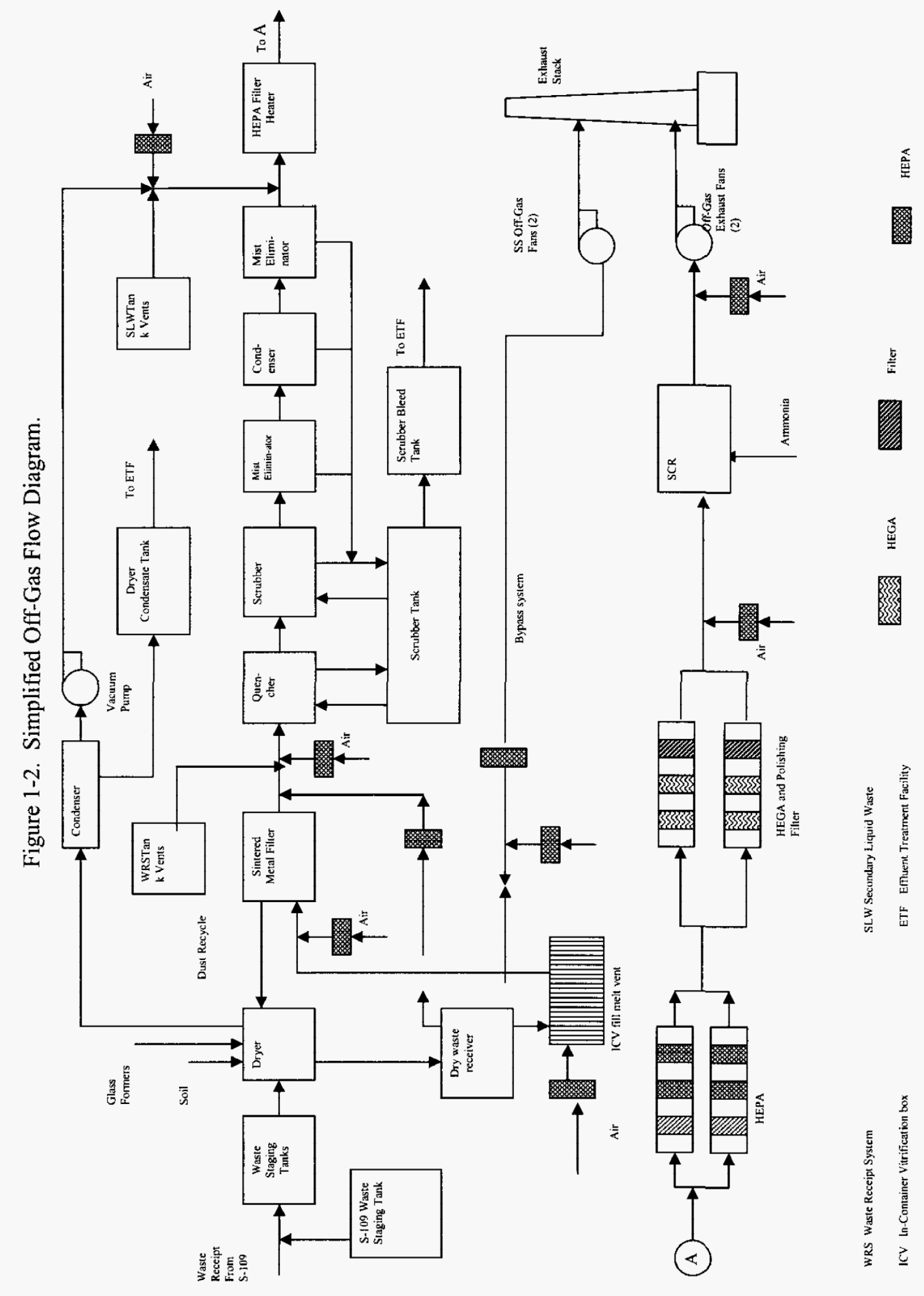

솔

网

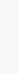

3्य

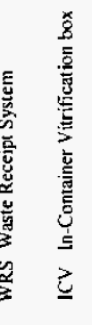


Hazard analysis of the DBVS, described in RPP-23429, identified some hazardous conditions that required further analysis. Some of these hazardous conditions were related to postulated dried waste releases from various areas of the DBVS. This document discusses the technical basis underlying the assignment of risk category and controls for representative accidents involving the release of dried radioactive waste.

The following three hazardous conditions were selected as representing dried radioactive waste release events. Each requires a different set of controls for mitigating the consequences.

- The first representative accident is a structural failure (e.g., breach) of the pneumatic transport system resulting in the release of dried radioactive powder to the atmosphere. This condition was selected because the energy imparted to the released dried waste by the action of the vacuum pump could potentially cause all of the released material to become airborne.

- The second representative accident is a breach in the discharge chute beneath the waste dryer resulting in a spill of dried waste from a height of approximately $11 \mathrm{ft}(3.4 \mathrm{~m})$. This accident could be the result of one of several possible causes, including vehicle impacts, a seismic or other NPH event, manufacturing defects, or installation errors.

- The third representative accident is release of dried waste caused by a filter that fails because of high temperature. This condition bounds the other filtration failures because the high temperature potentially releases the ${ }^{129} \mathrm{I}$ on the carbon filter as well as a fraction of the material on the HEPA filters.

\subsubsection{Bounding Offsite Accident}

Low-energy ground surface solids release events associated with the dried waste release accident have been quantitatively analyzed for comparison to the DOE-STD-3009-94, Appendix A, "Evaluation Guideline" of 25 rem to the public. The bounding quantitative analysis for the release of dried waste accident is documented in RPP-23429, and shows that offsite radiological consequences do not challenge the 25 rem evaluation guideline. Therefore, no safety-class SSCs or TSR-level controls for protection of the public need to be considered for offsite radiological exposures for any of the low-energy ground surface solid/sludge release events.

It is important to note that DOE-STD-3009-94 does not provide any other evaluation guidelines (i.e., evaluation guidelines are not provided for offsite toxicological, or onsite radiological and toxicological exposures). These exposures were evaluated for the representative accidents and associated hazardous conditions in accordance with the risk binning methodology described in Section 1.3. The results of evaluating the risk to the facility worker are documented in RPP-23429. 


\section{RPP-20725 REV 2}

\subsubsection{Associated Hazardous Conditions}

In addition to the hazardous conditions that define the representative accidents, the hazard evaluation database lists other hazardous conditions that are characterized by the representative accidents.

For the release of pneumatically transported dried waste from the Dried Waste Transfer System (DWTS) representative accident (due to vehicle impacts, seismic structural failure, manufacturing defects, or installation errors), the represented conditions are:

- Small hydraulic fire in hydraulic system skid located in International Organization for Standardization (ISO) freight container below the waste dryer causes weakening and collapse of ISO freight container support structure resulting in release of dried waste. Causes include hydraulic system hose leaks or equipment failures creates a spray of fluid that is ignited causing a small fire (blowtorch) under Waste Dryer ISO freight container that fails structural components; too high a hydraulic fluid pressure to waste dryer motor and damage to hydraulic hoses or motor casing or seals.

For the spill from beneath the dryer outlet representative accident, the represented conditions are:

- Free-fall spill from the ICV container resulting in the release of dried radioactive material to the atmosphere (various causes). This event involves an ICV box that is being moved from beneath the dryer due to receipt of a non-compliant dryer batch. The container is subsequently dropped or impacted by a vehicle, resulting in the release of dried radioactive material to the atmosphere.

- Failure of the seal between the ICV container and the lid due to misalignment or sealing lip damage.

For the filtration failure representative accident, the represented hazardous conditions are:

- Failure of the off-gas HEPA filters due to high pressure, causing a partial release of the waste loading on the filters.

- Unfiltered release due to error during filter maintenance, leakage around a misaligned filter or damage to the ductwork.

\subsection{RISK BINNING METHODOLOGY}

Direction on risk binning was provided by the U.S. Department of Energy Office of River Protection (Klein and Schepens 2003, "Replacement of Previous Guidance Provided by RL and ORP"). Risk binning begins with a qualitative evaluation of the frequency and consequence of the representative accident. Frequency is qualitatively estimated as "anticipated," "unlikely," "extremely unlikely," or "beyond extremely unlikely." Consequences are evaluated for the following receptors and exposures: offsite toxicological, onsite radiological, and onsite toxicological. These consequences are assigned to one of three levels: high, moderate, or low. 


\section{RPP-20725 REV 2}

Based on the frequency and consequence, risk bins (ranging from I to IV) are assigned. Tables 1-1 and 1-2 show the criteria for assigning the frequency and consequence levels, and the risk bins, which are assigned to the various combinations of frequency and consequence. After the risk binning process is completed for the representative accident, the process is then repeated for the represented hazardous conditions associated with the representative accident.

In accordance with the control selection guidelines in Klein and Schepens (2003), Risk Bin I events require safety-significant SSCs or TSRs, and Risk Bin II events must consider safety-significant SSCs and TSRs. Risk Bin III events are generally protected by the safety management programs, and Risk Bin IV events do not require additional measures.

Table 1-1. Offsite (Toxicological Only) Risk Bins.

\begin{tabular}{|c|c|c|c|c|}
\hline \multirow[b]{2}{*}{$\begin{array}{l}\text { Consequence category } \\
\text { (toxicological only*) }\end{array}$} & \multicolumn{4}{|c|}{ Event frequency } \\
\hline & $\begin{array}{c}\leq 10^{-6} / \text { yrBeyond } \\
\text { extremely unlikely }\end{array}$ & $\begin{array}{c}>10^{-6} \text { to } \\
\leq 10^{-4} / \mathrm{yrEx} \text { tremely } \\
\text { unlikely }\end{array}$ & $\begin{array}{c}>10^{-4} \text { to } \\
\leq 10^{-2} / \text { yrUnlikely }\end{array}$ & $\begin{array}{c}>10^{-2} \text { to } \leq 10^{-} \\
4 / \text { yrAnticipated }\end{array}$ \\
\hline $\begin{array}{l}\geq \text { ERPG-2 / TEEL-2 } \\
\text { (High) }\end{array}$ & III & II & I & I \\
\hline $\begin{array}{l}\text { >ERPG-1 / TEEL-1 to } \\
<\text { ERPG-2 / TEEL-2 } \\
\text { (Moderate) }\end{array}$ & IV & III & II & I \\
\hline $\begin{array}{l}<\text { ERPG-1 / TEEL-1 } \\
\text { (Low) }\end{array}$ & IV & IV & III & III \\
\hline
\end{tabular}

Safety SSCs and/or TSR-level controls considered/required.

No further consideration for safety SSCs and/or TSR-level controls.

* Radiological consequences for the offsite receptor are evaluated in accordance with DOE-STD-3009-94, 2002, Preparation Guide for U.S. Department of Energy Nonreactor Nuclear Facility Documented Safety Analyses, Change Notice No. 2, Appendix A, U.S. Department of Energy, Washington D.C.

ERPG = emergency response planning guideline. TEEL = Temporary Emergency Exposure Limit.

SSC = structures, systems, and components. $\quad$ TSR $=$ technical safety requirement. 
Table 1-2. Onsite (100 m) Risk Bins.

\begin{tabular}{|c|c|c|c|c|}
\hline \multirow{2}{*}{$\begin{array}{c}\text { Consequence category } \\
\text { (radiological/ } \\
\text { toxicological) }\end{array}$} & \multicolumn{4}{|c|}{ Event frequency } \\
\hline & $\begin{array}{c}\leq 10^{-6} / \text { yrBeyond } \\
\text { extremely unlikely }\end{array}$ & $\begin{array}{c}>10^{-6} \text { to } \\
\leq 10^{-4} / \text { yrExtremely } \\
\text { unlikely }\end{array}$ & $\begin{array}{c}>10^{-4} \text { to } \\
\leq 10^{-2} / \text { yrUnlikely }\end{array}$ & $\begin{array}{c}>10^{-2} \text { to } \leq 10^{-} \\
4 / y r \text { Anticipated }\end{array}$ \\
\hline $\begin{array}{l}\geq 100 \text { rem } \\
\geq \text { ERPG-3 / TEEL-3 } \\
\text { (High) }\end{array}$ & III & II & I & I \\
\hline $\begin{array}{l}\geq 25 \text { to } 100 \text { rem } \\
\geq \text { ERPG-2 / TEEL-2 to } \\
<\text { ERPG-3 / TEEL-3 } \\
\text { (Moderate) }\end{array}$ & IV & III & II & I \\
\hline $\begin{array}{l}<25 \text { rem } \\
<\text { ERPG-2 / TEEL-2 } \\
\text { (Low) }\end{array}$ & IV & IV & III & III \\
\hline
\end{tabular}

Safety SSCs and/or TSR-level controls considered/required.

No further consideration for safety SSCs and/or TSR-level controls.

ERPG = emergency response planning guideline.

SSC = structures, systems, and components.
TEEL = Temporary Emergency Exposure Limit.

TSR = technical safety requirement.

Environmental consequences are also assigned during the risk binning process. There are four categories of environmental consequences (E0, E1, E2, and E3, in order of increasing severity) and these categories are defined in Table 1-3.

Table 1-3. Environmental Consequence Categories.

\begin{tabular}{|c|l|}
\hline Category & \multicolumn{1}{c|}{ Definition } \\
\hline E3 & Offsite discharge or discharge to groundwater \\
\hline E2 & Significant discharge onsite \\
\hline E1 & Localized discharge \\
\hline E0 & No significant environmental consequence \\
\hline
\end{tabular}




\subsection{RISK BIN EVALUATION}

\subsection{RELEASE OF DRIED WASTE}

During several Process and Hazard/Operability Analysis and control decision meetings, consensus was obtained on the assignment of frequencies, consequences, and controls. The meeting attendees represented a wide range of expertise in the areas of engineering, licensing, and operations. Appendix A lists the meeting attendees. The risk binning results for scenarios considered in this document are shown in Table 2-1.

Scoping calculations were performed to support the assignment of consequence bins. These calculations are presented in Appendix B. The risk binning results are shown in Table 2-1.

Table 2-1. Risk Binning Results for Dried Waste Releases. (2 sheets)

\begin{tabular}{|c|c|c|c|c|c|c|c|c|}
\hline \multirow[b]{2}{*}{ Postulated accident } & \multirow[b]{2}{*}{ Frequency } & \multicolumn{4}{|c|}{ Consequences } & \multicolumn{3}{|c|}{ Risk bin } \\
\hline & & 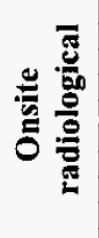 & 总 & 莺 & 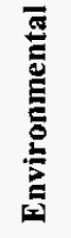 & 苞 & 竎 & 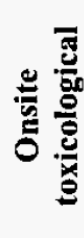 \\
\hline $\begin{array}{l}\text { Release of pneumatically transported dried } \\
\text { radioactive waste due to vehicle impacts, } \\
\text { seismic structural failure, manufacturing } \\
\text { defects, or installation errors (representative } \\
\text { accident 1) }\end{array}$ & $\mathrm{U}$ & $\mathrm{L}$ & $\mathrm{L}$ & $\mathrm{H}$ & E2 & III & III & I \\
\hline $\begin{array}{l}\text { Spills and falls of dried radioactive waste } \\
\text { from the bottom of the dryer outlet, a height } \\
\text { of approximately } 11 \mathrm{ft} \text { (representative } \\
\text { accident } 2 \text {; various causes) }\end{array}$ & $\mathrm{U}$ & $\mathrm{L}$ & $\mathrm{L}$ & $\mathrm{H}$ & E2 & III & III & I \\
\hline $\begin{array}{l}\text { Small fire (e.g., resulting from vehicle } \\
\text { impact, or hydraulic system leak) that } \\
\text { causes weakening and failure of the waste } \\
\text { dryer steel superstructure resulting in a fall } \\
\text { of dried waste from greater than } 3 \mathrm{~m} \\
\text { (represented accident). }\end{array}$ & $\mathrm{U}$ & $L$ & $\mathrm{~L}$ & $\mathrm{H}$ & E1 & III & III & I \\
\hline $\begin{array}{l}\text { Release of dried radioactive waste from the } \\
\text { ICV container after relocation from melt } \\
\text { area due to interrupted melt (represented } \\
\text { accident) }\end{array}$ & $\mathrm{U}$ & $\mathrm{L}$ & $\mathrm{L}$ & $\mathrm{H}$ & $\mathrm{E} 2$ & III & III & I \\
\hline $\begin{array}{l}\text { Lid fails to seal to the ICV container due to } \\
\text { misalignment or sealing lip damage } \\
\text { (represented accident) }\end{array}$ & A & $\mathrm{L}$ & $\mathrm{L}$ & M & E2 & III & III & 1 \\
\hline $\begin{array}{l}\text { Off-gas system filtration failures } \\
\text { (representative accident } 3 \text { ) }\end{array}$ & A & L & $\mathrm{L}$ & M & E1 & III & III & I \\
\hline
\end{tabular}


Table 2-1. Risk Binning Results for Dried Waste Releases. (2 sheets)

\begin{tabular}{|c|c|c|c|c|c|c|c|c|}
\hline \multirow[b]{2}{*}{ Postulated accident } & \multirow[b]{2}{*}{ Frequency } & \multicolumn{4}{|c|}{ Consequences } & \multicolumn{3}{|c|}{ Risk bin } \\
\hline & & 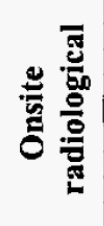 & 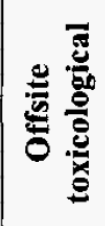 & 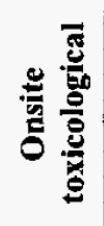 & 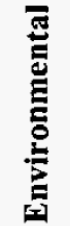 & 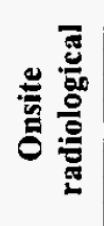 & 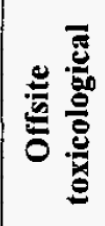 & 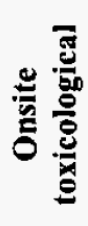 \\
\hline
\end{tabular}

Notes:

$\mathrm{A}=$ anticipated.

E2 = significant discharge onsite

$\mathrm{H}=$ high.

ICV $=$ In-Container Vitrification.

$\mathrm{L}=$ low.

$\mathrm{M}=$ moderate.

$\mathrm{U}=$ unlikely.

\subsubsection{Representative Accident 1: Release of Dried Waste During Pneumatic Transfer}

\subsubsection{Accident Scenario}

As part of the DBVS waste processing system, waste will be mixed with clean soil and glass formers and dried before being pneumatically conveyed to the dried waste receiver for eventual delivery to the ICV container for vitrification. In this accident scenario, there is a failure of the pneumatic transfer line downstream of the vacuum pump during transport of the waste. The result is release of the dried material to the atmosphere. It is conservatively assumed that there is no confinement and the solids move as a free-flowing powder.

\subsubsection{Frequency Determination}

Failure of the pneumatic transfer line could be the result of one of several possible causes, including vehicle impacts, a seismic event, manufacturing defects, or installation errors. The design basis earthquake has a return period that puts it in the "unlikely" frequency range. Failures due to manufacturing defects or installation errors are judged to be "unlikely" because the equipment will be new, and the facility has a limited operating life. Additionally, all systems will be tested during startup with non-hazardous materials prior to operating with the tank waste. Even though vehicle accidents are considered anticipated events, the portion of the transfer line downstream of the vacuum pump is in a location that is relatively inaccessible by vehicle traffic. Therefore, the event was assigned a frequency bin of "unlikely."

\subsubsection{Consequence Determination}

To provide an estimate of the radiological and toxicological consequences, scoping calculations were performed and are documented in Appendix B. The accident scenario, without controls, 


\section{RPP-20725 REV 2}

assumes that during transport of the dried waste mixture the pneumatic transfer line fails. The waste is released to the atmosphere.

The release is assumed to contain a complete waste dryer batch $(7,040 \mathrm{~kg})$ of dried waste mixture. A batch of waste mixture will consist of SST 241-S-109 salt solution mixed with soil and subsequently dried. It is assumed that the liquid waste entrains as much as $0.25 \mathrm{wt} \%$ of sludge. Undiluted waste is assumed as feed to the waste dryer even though an overall fresh water dilution factor of $3.37: 1$ is expected.

The radiological unit-liter doses (ULD) and toxicological sum of fraction (SOF) multipliers for SST 241-S-109 waste were taken from RPP-CALC-30596, Demonstration Bulk Vitrification System Accident Analysis Source Terms. The atmospheric dispersion factors are from RPP-13482, Atmospheric Dispersion Coefficients and Radiological and Toxicological Exposure Methodology for Use in Tank Farms, and the airborne release fraction, respirable fraction, and airborne release rate are from DOE-HDBK-3010-94, Airborne Release Fractions/Rates and Respirable Fractions for Nonreactor Nuclear Facilities.

A complete list of the analysis assumptions is presented in Table 2-2. The table includes, for each assumption, information on the potential effect of changes in the assumption, and the need to evaluate or protect the assumption.

\subsection{Assignment of Consequence Bins}

Although the evaluation of consequences was intended to be qualitative, there were no previous analyses of releases of dried radioactive waste powder to provide a frame of reference for the qualitative judgment. Therefore the consequences were estimated by scoping calculations as shown in Appendix B.

Tables 2-3 and 2-4 compare the calculated consequences of the representative accident to the radiological and toxicological risk evaluation guidelines. The onsite radiological consequences for the release from the DWTS were below the $25 \mathrm{rem}$ "moderate" consequence guideline; therefore, they were assigned to a consequence bin of "low." The SOF for the offsite toxicological consequences was 0.56 , below the "moderate" consequence guideline. Therefore, they were assigned to the "low" consequence bin. The onsite toxicological consequences exceeded both the moderate and high consequence guidelines, thus they were assigned to a "high" consequence bin. 


\section{RPP-20725 REV 2}

\begin{tabular}{|c|c|c|c|c|c|c|}
\hline & 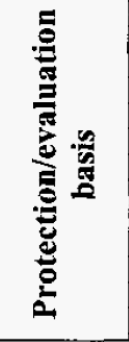 & 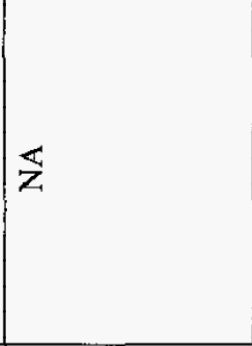 & $\mathbb{z}$ & $\mathbb{z}$ & $\widetilde{z}$ & 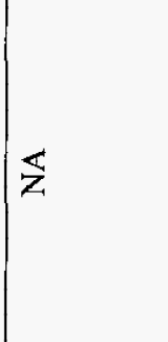 \\
\hline & 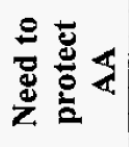 & z & z & Z & $\dot{z}$ & $\stackrel{0}{z}$ \\
\hline & 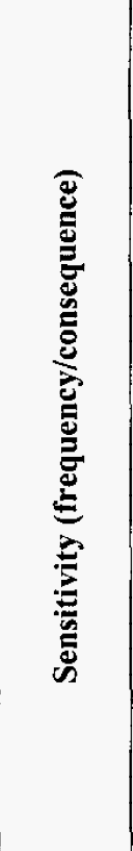 & 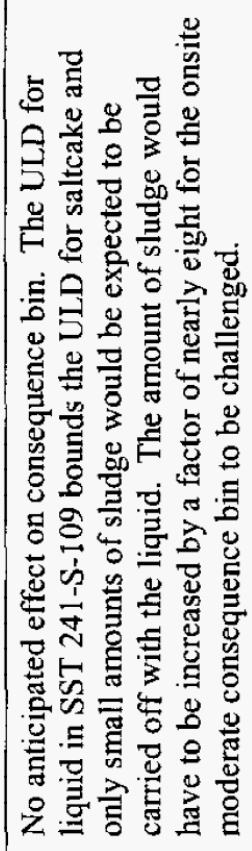 & 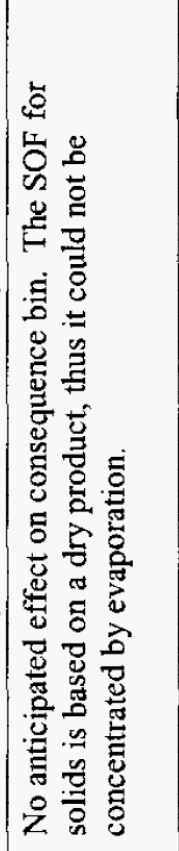 & 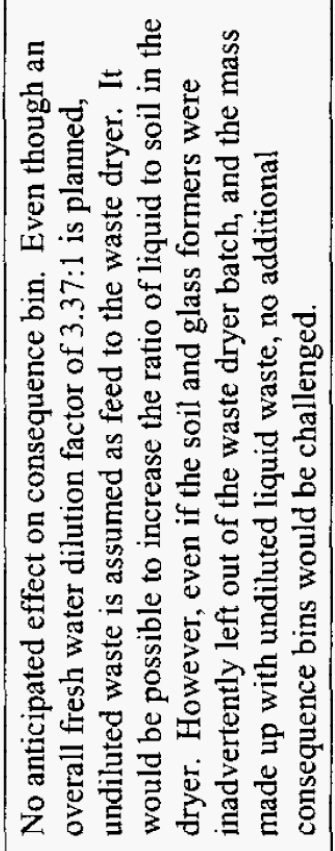 & 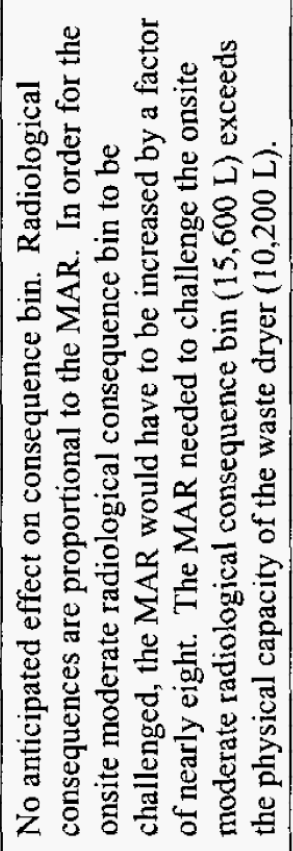 & 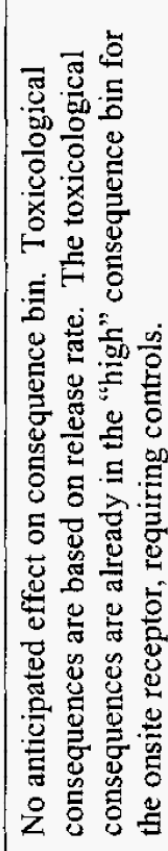 \\
\hline & 产 & 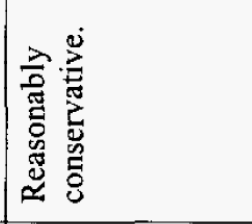 & 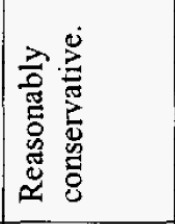 & 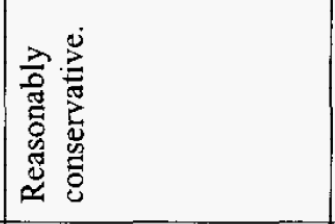 & 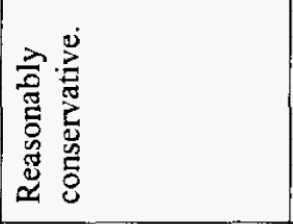 & 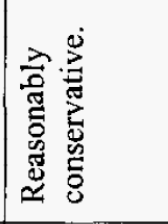 \\
\hline & 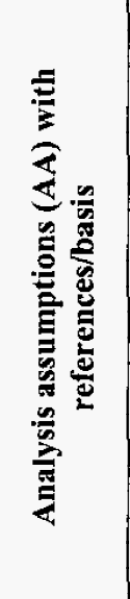 & 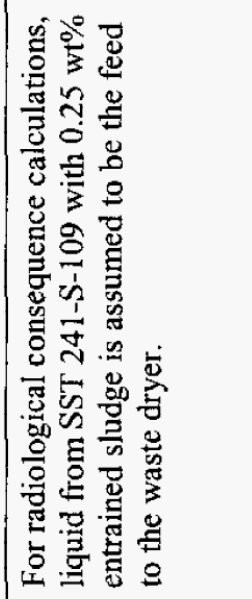 & 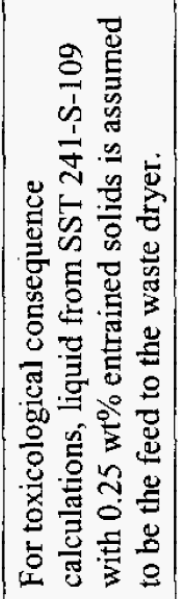 & 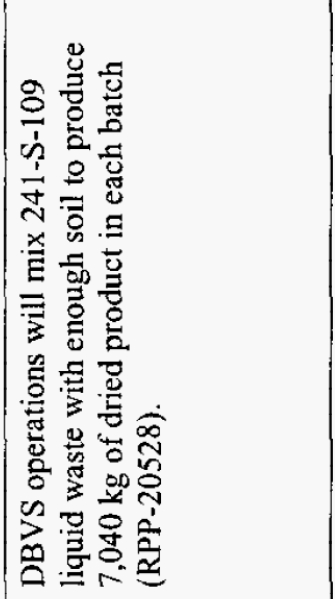 & 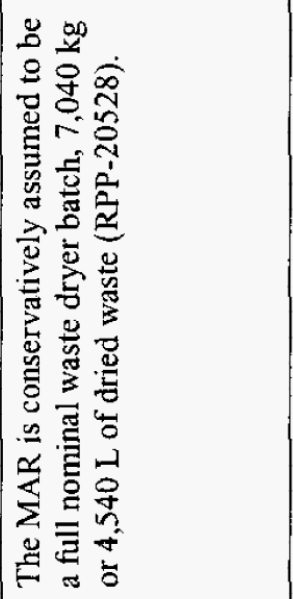 & 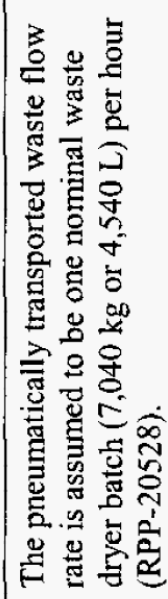 \\
\hline
\end{tabular}




\section{RPP-20725 REV 2}

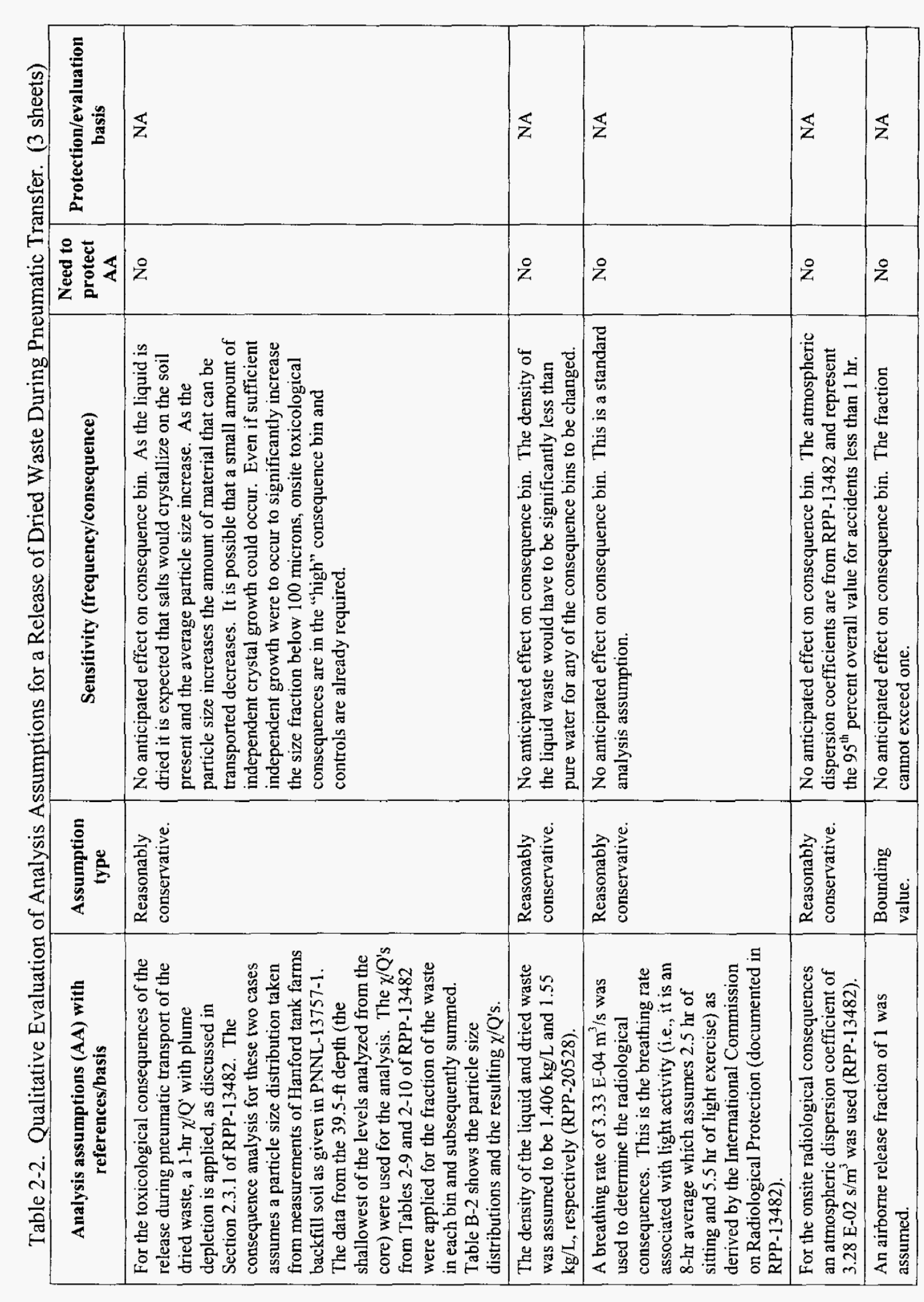

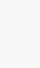


RPP-20725 REV 2

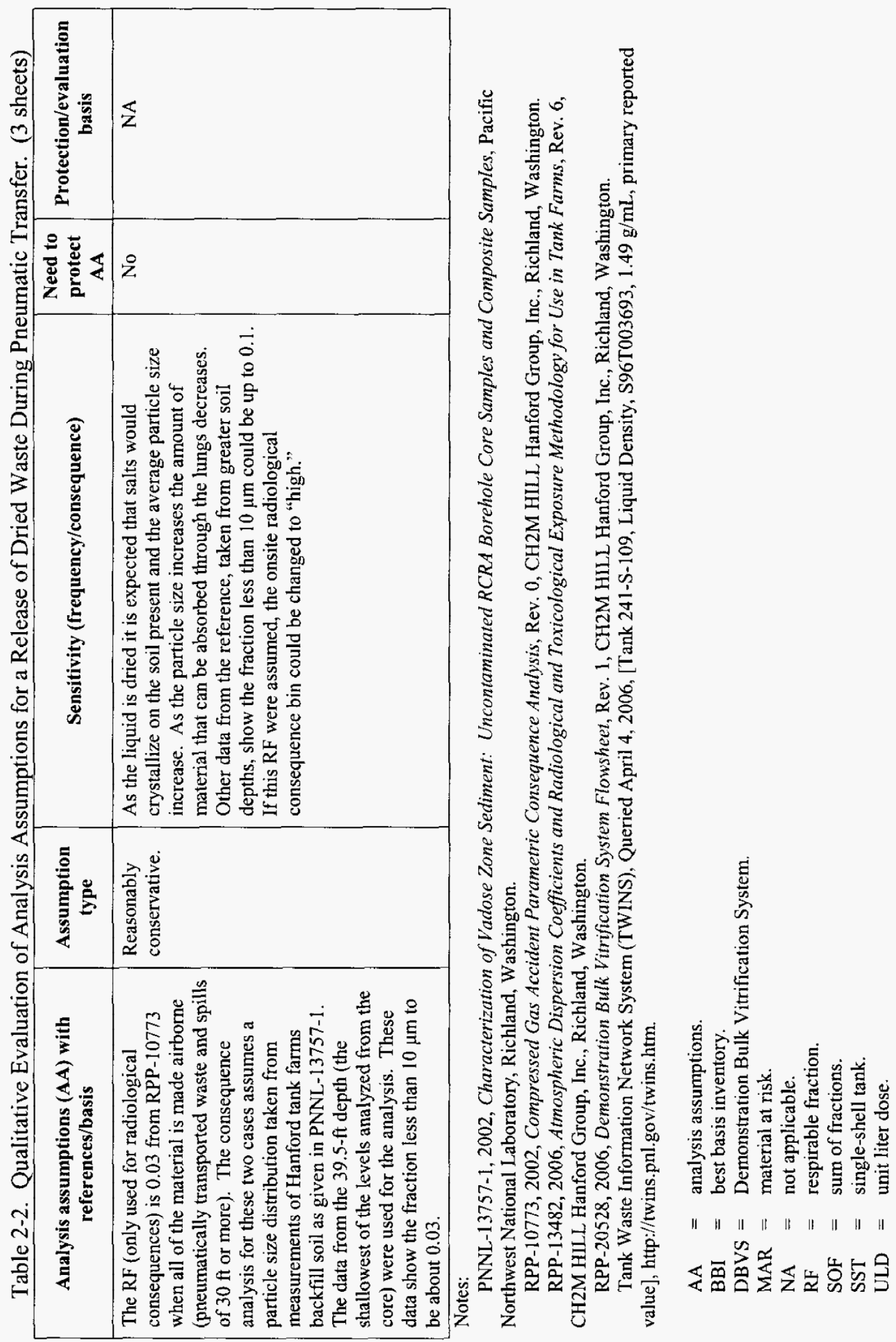


Table 2-3. Summary of Onsite Radiological Consequences Without Controls for the Release of Dried Radioactive Waste During Pneumatic Transport.

\begin{tabular}{|c|c|c|c|}
\hline \multirow{2}{*}{ Case } & \multicolumn{3}{|c|}{ Onsite radiological consequences } \\
\cline { 2 - 4 } & $\begin{array}{c}\text { Calculated dose } \\
\text { (rem) }\end{array}$ & $\begin{array}{c}\text { Moderate } \\
\text { consequence } \\
\text { guideline } \\
\text { (rem) }\end{array}$ & $\begin{array}{c}\text { High consequence } \\
\text { guideline } \\
\text { (rem) }\end{array}$ \\
\hline $\begin{array}{l}\text { Release of pneumatically } \\
\text { transported dried radjoactive waste }\end{array}$ & 3.4 & 25 & 100 \\
\hline
\end{tabular}

Table 2-4. Summary of Toxicological Consequences Without Controls for the Release of Dried Radioactive Waste during Pneumatic Transport.

\begin{tabular}{|c|c|c|c|c|c|c|c|c|}
\hline \multirow{4}{*}{ Case } & \multicolumn{8}{|c|}{ Toxicological Consequences } \\
\hline & \multicolumn{4}{|c|}{ Onsite } & \multicolumn{4}{|c|}{ Offsite } \\
\hline & \multicolumn{2}{|c|}{$\begin{array}{c}\text { Moderate } \\
\text { consequence }\end{array}$} & \multicolumn{2}{|c|}{$\begin{array}{c}\text { High } \\
\text { consequence }\end{array}$} & \multicolumn{2}{|c|}{$\begin{array}{c}\text { Moderate } \\
\text { consequence }\end{array}$} & \multicolumn{2}{|c|}{$\begin{array}{c}\text { High } \\
\text { consequence }\end{array}$} \\
\hline & SOF & Guideline & SOF & Guideline & SOF & Guideline & SOF & Guideline \\
\hline $\begin{array}{l}\text { Release of } \\
\text { pneumatically } \\
\text { transported } \\
\text { dried } \\
\text { radioactive } \\
\text { waste }\end{array}$ & 284 & 1 & 18.1 & 1 & 0.56 & 1 & 0.083 & 1 \\
\hline
\end{tabular}

\subsection{Assignment of Environmental Consequences}

An environmental consequence of E2 was assigned because a discharge of approximately $7,040 \mathrm{~kg}$ of powder was judged to be a significant onsite discharge.

\subsection{Assignment of Risk Bins}

Table 2-1 summarizes the frequency, consequence, and risk bin assignments for the release of dried waste during pneumatic transfer representative accident. The assignment of risk bins is derived from the consequences and estimated frequency of the accident. The risk bin for the offsite toxicological receptor is III because the consequence is "low" and the estimated frequency is "unlikely." The risk bin for the onsite toxicological receptor is I because the consequence is "high" and the estimated frequency is "unlikely." The onsite radiological risk bin is III due to the "low" consequences and "unlikely" frequency. 


\subsubsection{Associated Hazardous Conditions}

The results of the risk binning process for the hazardous conditions covered by the representative accidents in this document are contained within the hazard evaluation database. The hazard evaluation database includes the basis for each consequence and frequency. Consensus was reached by the risk binning team that all the represented hazardous conditions were bounded by the representative accidents.

The risk binning team considered the process design as well as the conservatisms in the analysis when assigning consequence and frequency bins to the other represented hazardous conditions. The results are presented with the representative accidents in Table 2-1, and are discussed below.

\subsubsection{Release of Dried Waste (Height Greater than $3 \mathrm{~m}$ ) Due to Small Fire-Induced Dryer Superstructure Failure and Subsequent Waste Dryer Collapse}

\subsubsection{Accident Scenario}

In this scenario, a small fire (e.g., resulting from a vehicle impact or a hydraulic system leak) causes weakening and failure of the steel superstructure supporting the waste dryer resulting in a collapse of the waste dryer and a subsequent fall of dried waste from greater than $3 \mathrm{~m}$.

\subsubsection{Frequency Determination}

The frequency was judged to be "unlikely" based on RPP-30361, Technical Basis for DBVS Fires and Explosions, which qualitatively determined that the frequency of a leak or crack developing in the hydraulic system, and the leak making contact with a source of ignition, is "unlikely."

\subsubsection{Consequence Determination}

The consequences for this scenario were conservatively estimated to be the same as for the release during pneumatic transfer accident. The onsite radiological and offsite toxicological consequences were estimated to be "low." The onsite toxicological consequences were estimated to be "high."

\subsubsection{Risk Bin Results Without Controls}

Table 2-1 summarizes the frequency, consequences, and risk bin without controls for this postulated dried waste release accident. An "unlikely" frequency and "high" consequence results in this scenario being categorized as Risk Bin I for onsite toxicological consequences. 


\subsubsection{Representative Accident 2: Spills and Falls of Dried Waste from Beneath the Waste Dryer Outlet (Greater Than $3 \mathrm{~m}$ Spill)}

\subsubsection{Accident Scenario}

Dried waste mixture is discharged from the dryer through a remotely controlled valve (33-YV-013) to the Dried Waste Handling System. Initiation of the transfer of dry waste feed to the ICV System is performed when the dried waste is at the right target moisture. Valve 33-YV-013 is opened and material is released into the discharge chute below the dryer. This condition can occur when there is a breach of confinement that allows the waste to be spilled from the discharge chute beneath the dryer outlet. For the release from beneath the waste dryer, because of the fall height (approximately $11 \mathrm{ft}$ or $3.4 \mathrm{~m}$ ), it is assumed, that the entire material at risk becomes airborne.

\subsubsection{Frequency Determination}

This failure could be the result of one of several possible causes, including vehicle impacts, a seismic event, manufacturing defects, or installation errors. The design basis earthquake has a return period that puts it in the "unlikely" frequency range. Failures due to manufacturing defects or installation errors are judged to be "unlikely" because the equipment will be new, and all systems will be tested during startup with non-hazardous materials prior to operating with the tank waste. Therefore, the event was assigned a frequency bin of "unlikely."

\subsubsection{Consequence Determination}

To provide an estimate of the radiological and toxicological consequences, scoping calculations were performed and are documented in Appendix B. The accident scenario, without controls, assumes that during transport of the dried waste mixture from the waste dryer to the ICV container, there is a breach in the discharge chute beneath the waste dryer. The dried waste is spilled on the ground or other hard surface from a height greater than $3 \mathrm{~m}$.

The release is assumed to contain a complete waste dryer batch $(7,040 \mathrm{~kg})$ of dried waste mixture. A batch of waste mixture will consist of SST 241-S-109 salt solution mixed with soil and subsequently dried. It is assumed that the liquid waste entrains as much as $0.25 \mathrm{wt} \%$ of sludge. Undiluted waste is assumed as feed to the waste dryer even though an overall fresh water dilution factor of $3.37: 1$ is expected.

The radiological ULDs and toxicological SOF multipliers for the dried and processed SST 241-S-109 waste were taken from RPP-CALC-30596. The atmospheric dispersion factors are from RPP-13482, and the airborne release fraction, respirable fraction, and airborne release rate are from DOE-HDBK-3010-94.

A complete list of the analysis assumptions is presented in Table 2-5. The table includes, for each assumption, information on the potential effect of changes in the assumption, and the need to evaluate or protect the assumption. 


\subsection{Assignment of Consequence Bins}

Although the evaluation of consequences was intended to be qualitative, scoping calculations were used to provide a frame of reference for the qualitative judgment. Results of the scoping calculations are shown in Appendix B.

Tables 2-6 and 2-7 compare the calculated consequences of the represented accident to the radiological and toxicological risk evaluation guidelines. The onsite radiological consequences for the fall or drop of dried waste from beneath the waste dryer outlet (greater than $3 \mathrm{~m}$ high) were below the 25 rem "moderate" consequence guideline; therefore, they were assigned to a consequence bin of "low." The onsite toxicological consequences were above the "high" consequence guideline. Therefore, they were assigned to the "high" consequence bin. The offsite toxicological consequences are below the moderate consequence guidelines, thus they were assigned to a "low" consequence bin. 
RPP-20725 REV 2

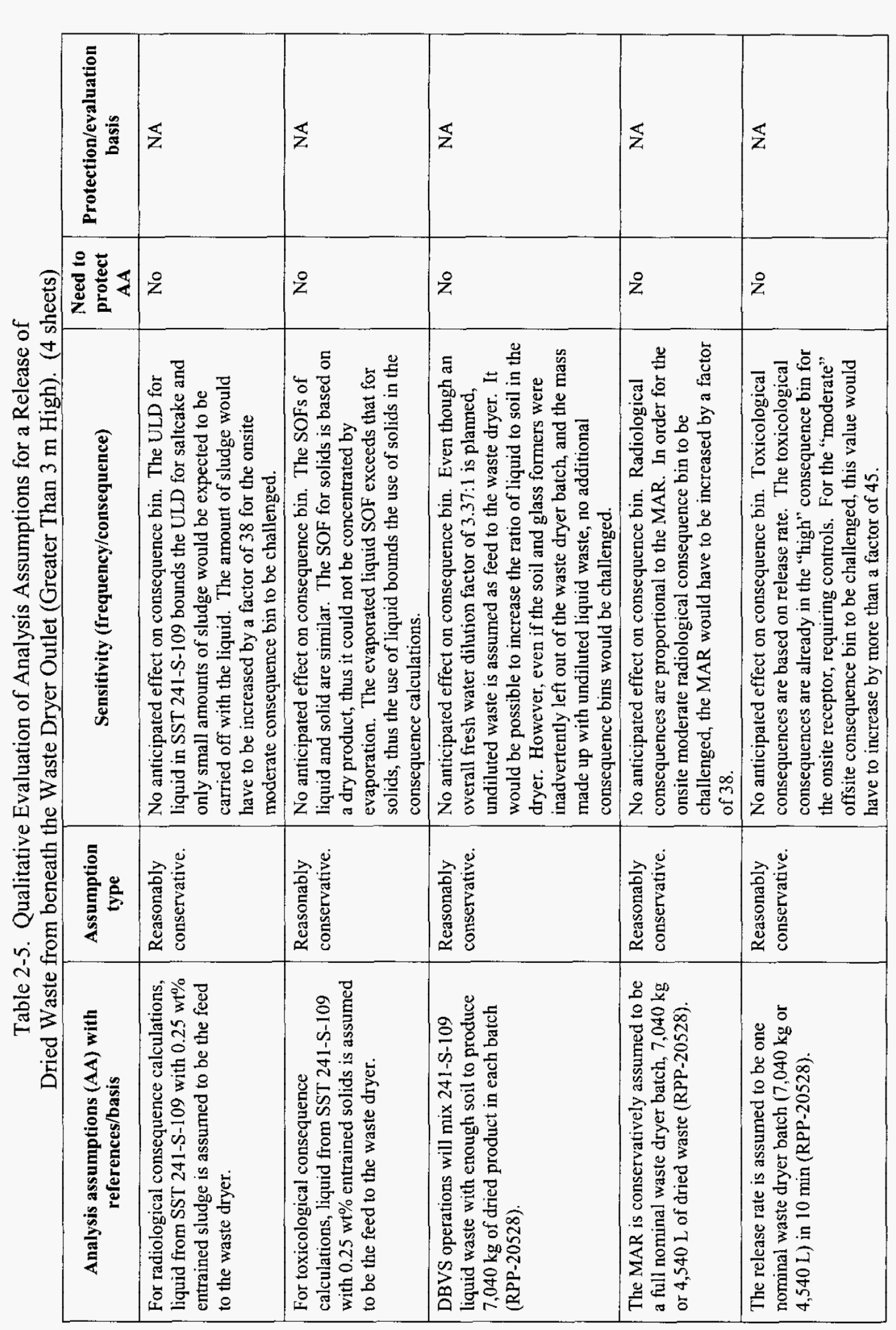

RPP-20725 REV 2

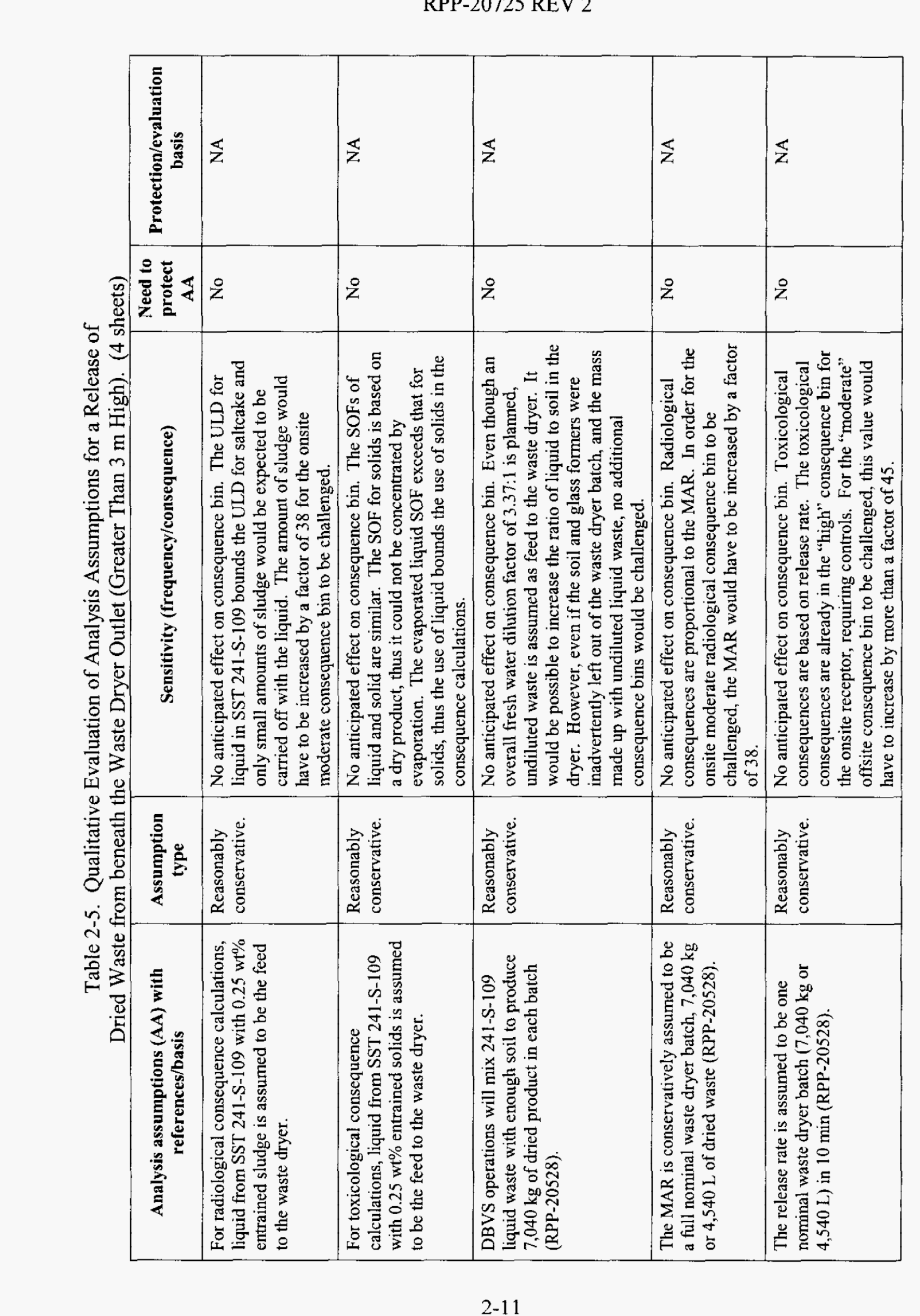

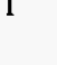



西

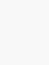
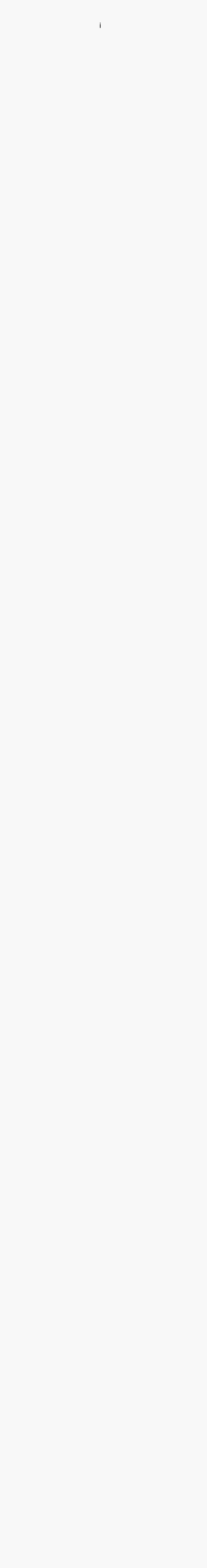
RPP-20725 REV 2

\begin{tabular}{|c|c|c|c|c|c|}
\hline & 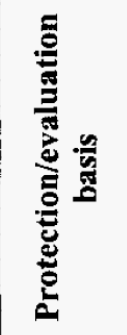 & $\mathbb{z}$ & $\widetilde{z}$ & 艺 & $\overleftarrow{z}$ \\
\hline 昰 & 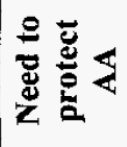 & z & $\stackrel{\circ}{z}$ & z & $z$ \\
\hline 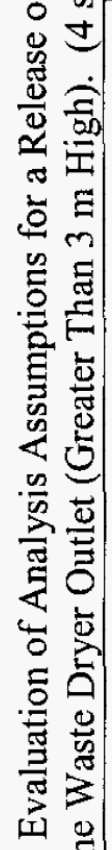 & 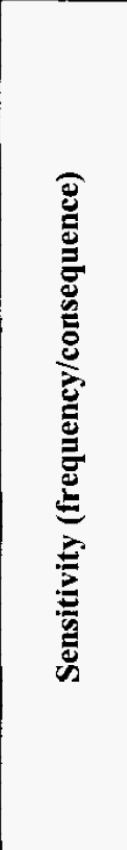 & 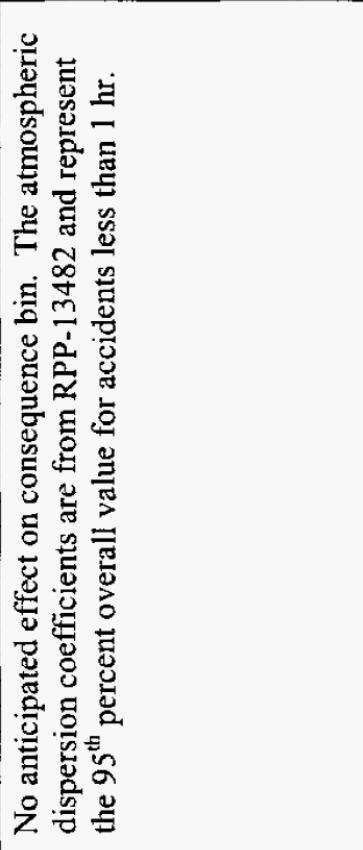 & 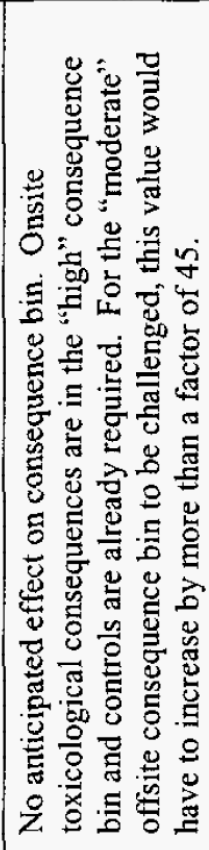 & 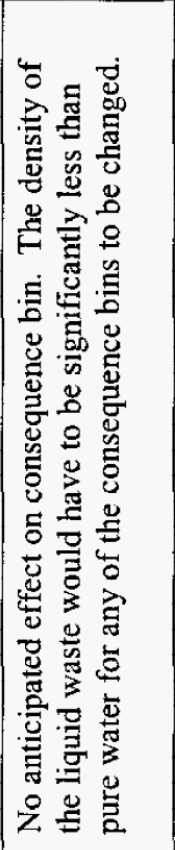 & 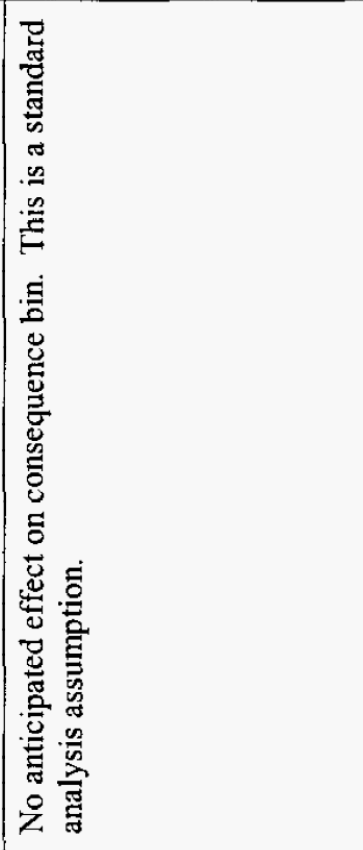 \\
\hline 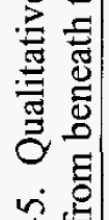 & 高 & 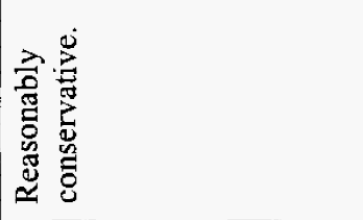 & 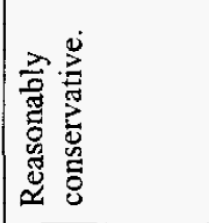 & 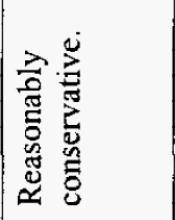 & 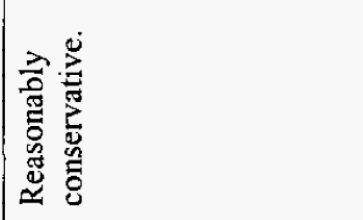 \\
\hline 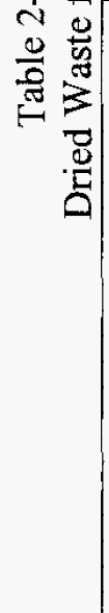 & 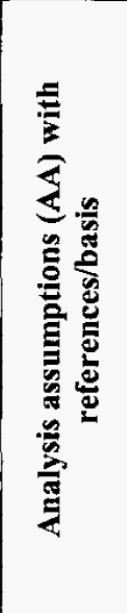 & 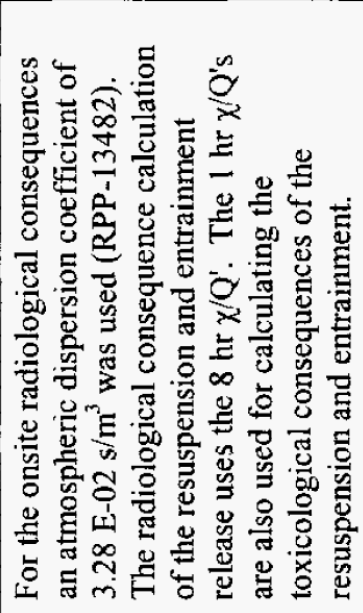 & 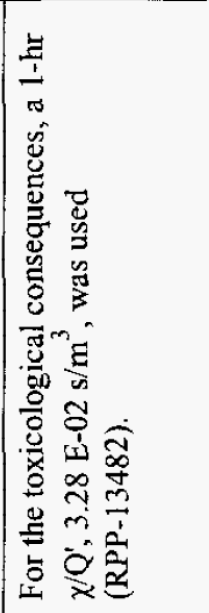 & 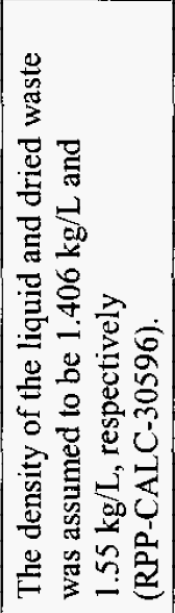 & 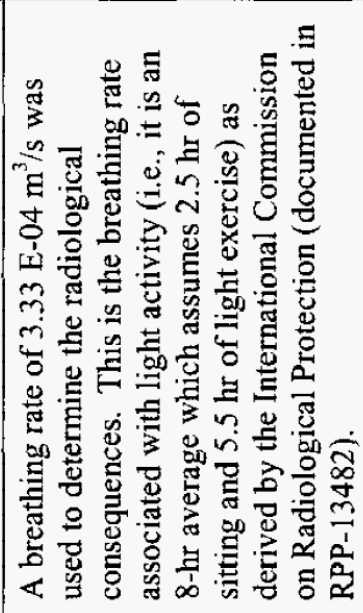 \\
\hline
\end{tabular}

REV 2

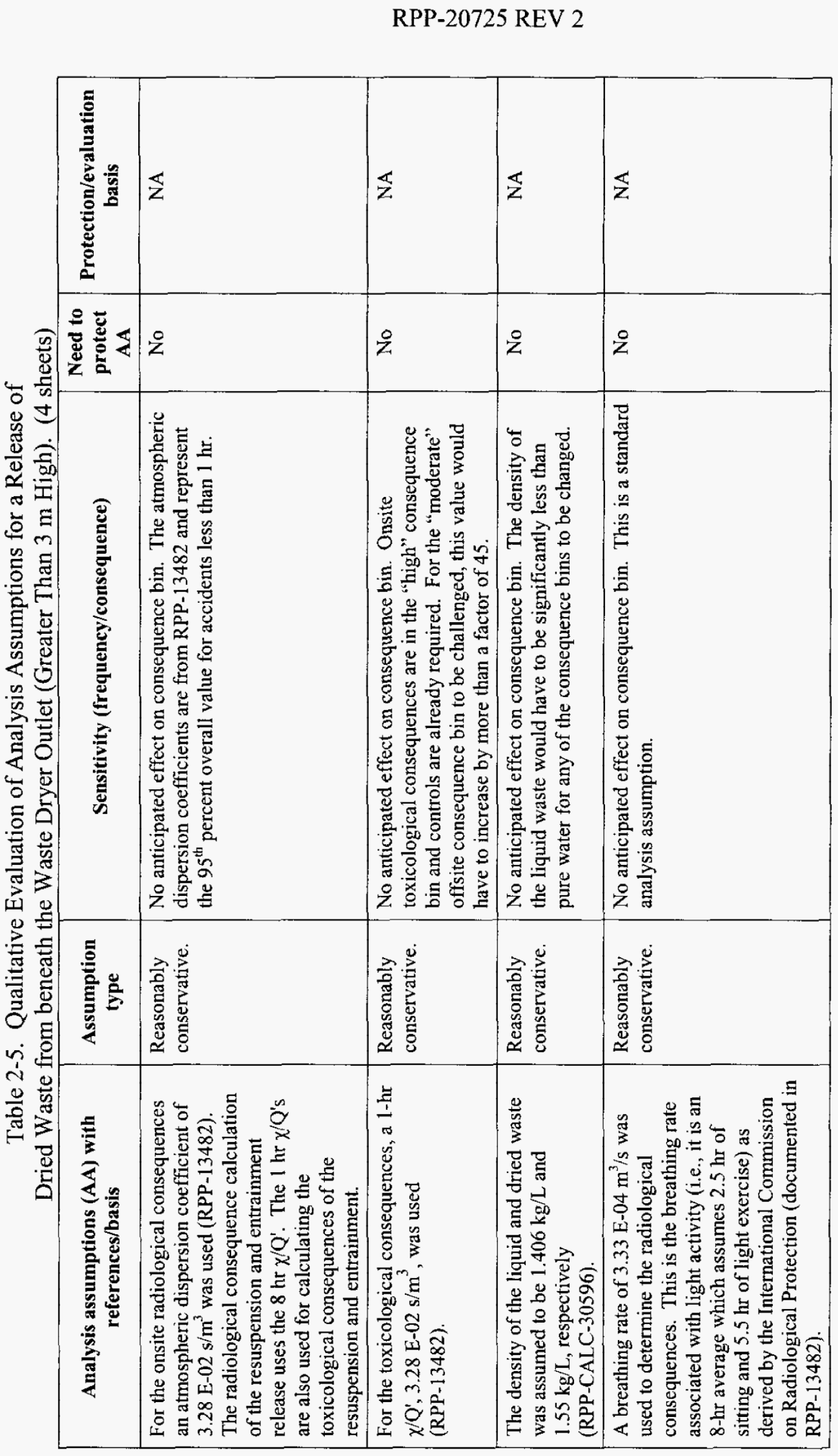

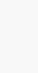

.


RPP-20725 REV 2

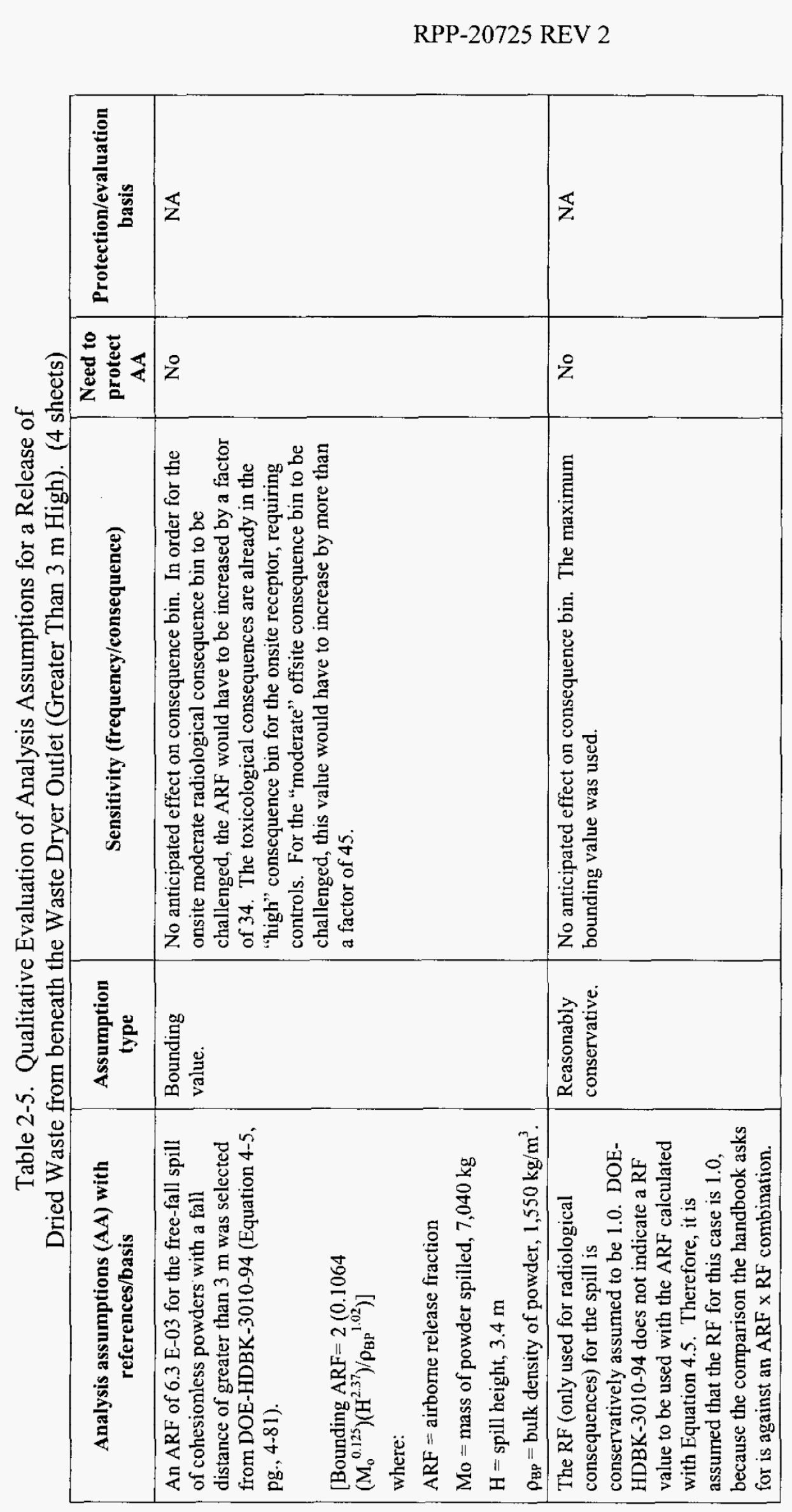


RPP-20725 REV 2

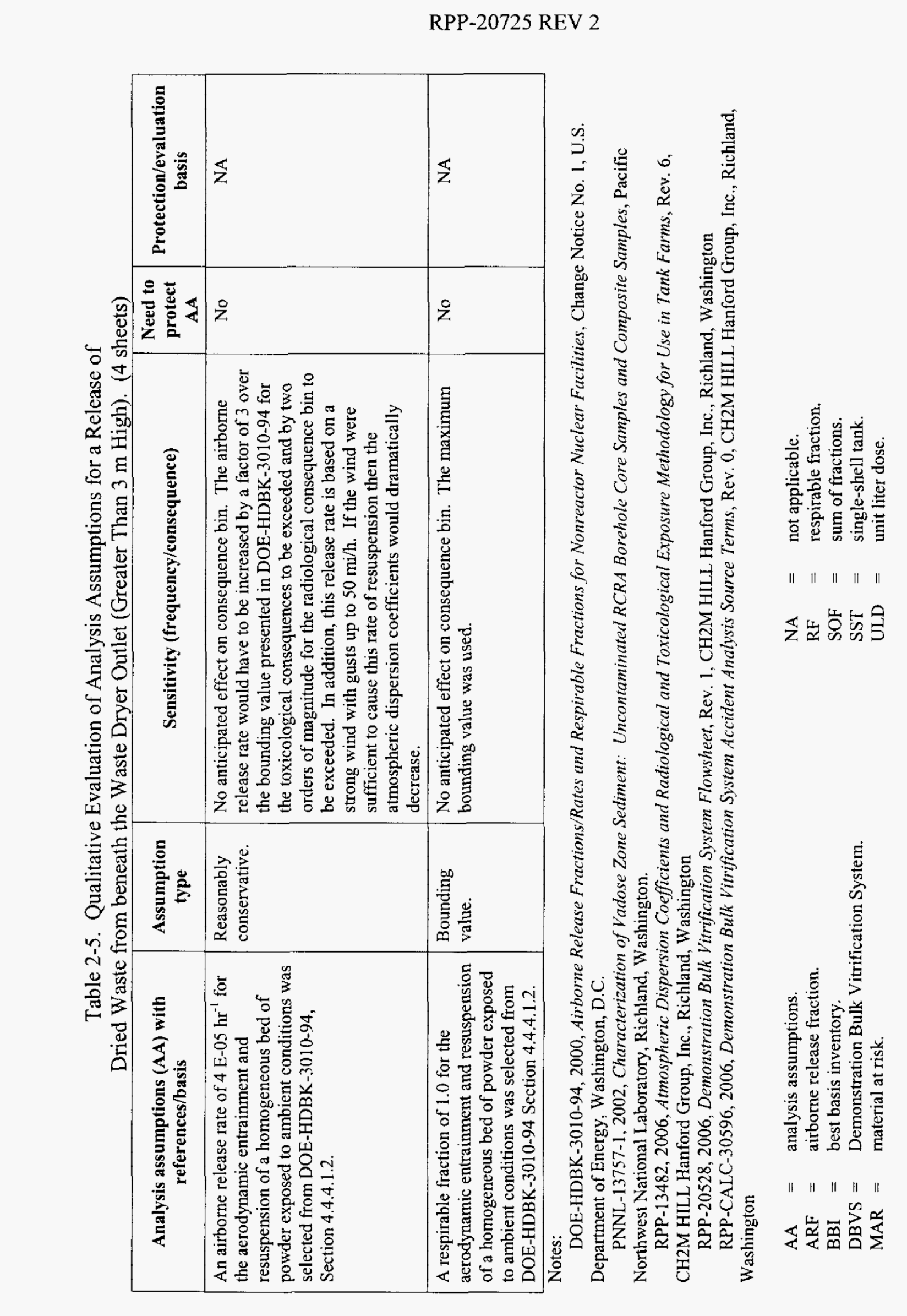

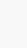
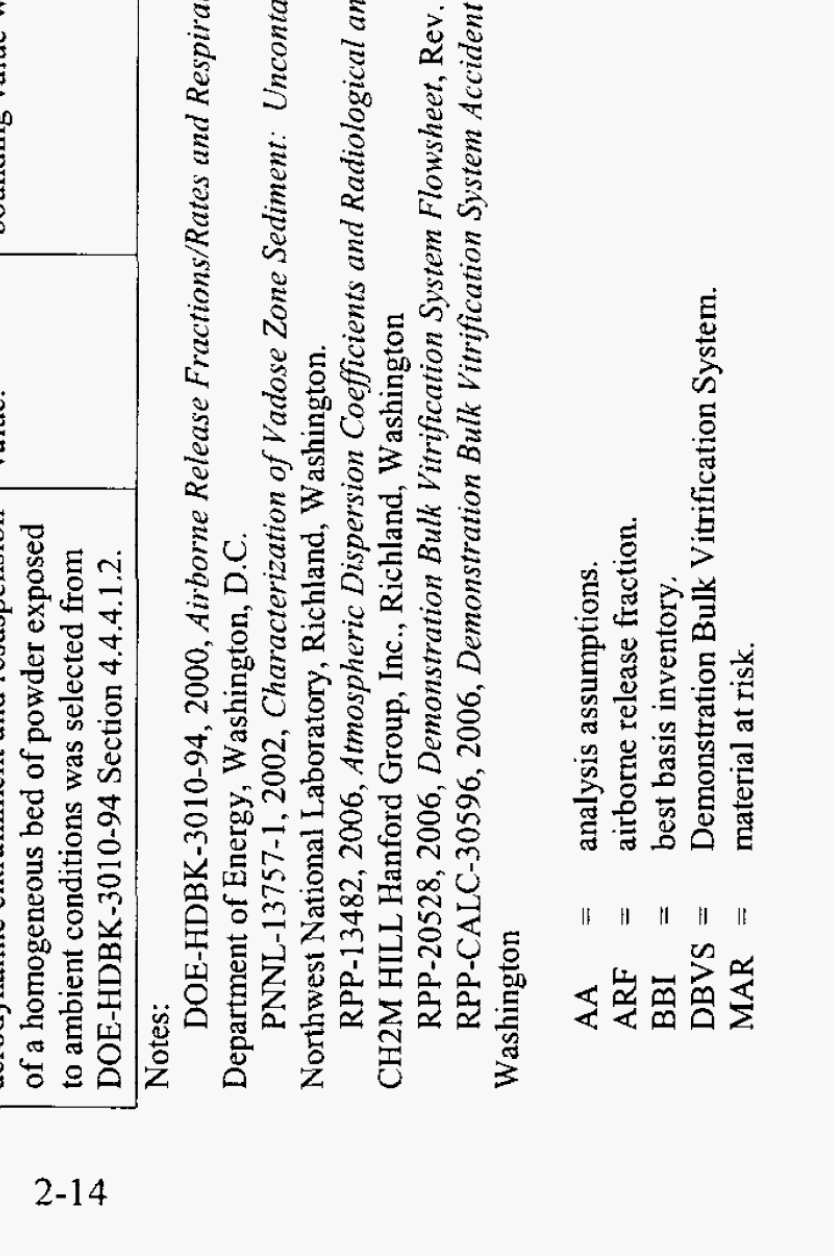
Table 2-6. Summary of Onsite Radiological Consequences Without Controls for the Spill of Dried Waste from Beneath the Waste Dryer Outlet (Greater Than $3 \mathrm{~m}$ High).

\begin{tabular}{|l|c|c|c|}
\hline \multirow{2}{*}{ Case } & \multicolumn{2}{|c|}{ Onsite radiological consequences } \\
\cline { 2 - 4 } & $\begin{array}{c}\text { Calculated dose } \\
\text { (rem) }\end{array}$ & $\begin{array}{c}\text { Moderate } \\
\text { consequence } \\
\text { guideline } \\
\text { (rem) }\end{array}$ & $\begin{array}{c}\text { High consequence } \\
\text { guideline } \\
\text { (rem) }\end{array}$ \\
\hline $\begin{array}{l}\text { Spill and drop of dried waste from } \\
\text { beneath the waste dryer outlet } \\
\text { (greater than 3 m) }\end{array}$ & 0.73 & 25 & 100 \\
\hline
\end{tabular}

Table 2-7. Summary of Toxicological Consequences Without Controls for the Spill of Dried Waste from Beneath the Waste Dryer Outlet (Greater Than $3 \mathrm{~m}$ High).

\begin{tabular}{|c|c|c|c|c|c|c|c|c|}
\hline \multirow{4}{*}{ Case } & \multicolumn{8}{|c|}{ Toxicological Consequences } \\
\hline & \multicolumn{4}{|c|}{ Onsite } & \multicolumn{4}{|c|}{ Offsite } \\
\hline & \multicolumn{2}{|c|}{$\begin{array}{c}\text { Moderate } \\
\text { consequence }\end{array}$} & \multicolumn{2}{|c|}{$\begin{array}{c}\text { High } \\
\text { consequence }\end{array}$} & \multicolumn{2}{|c|}{$\begin{array}{c}\text { Moderate } \\
\text { consequence }\end{array}$} & \multicolumn{2}{|c|}{$\begin{array}{c}\text { High } \\
\text { consequence }\end{array}$} \\
\hline & SOF & Guideline & SOF & Guideline & SOF & Guideline & SOF & Guideline \\
\hline $\begin{array}{l}\text { Spill and drop } \\
\text { of dried waste } \\
\text { from beneath } \\
\text { the waste dryer } \\
\text { outlet (greater } \\
\text { than } 3 \mathrm{~m} \text { ) }\end{array}$ & 152 & 1 & 9.7 & 1 & $2.2 \mathrm{E}-02$ & 1 & -- & 1 \\
\hline
\end{tabular}

Note:

SOF $=$ sum of fractions.

\subsection{Assignment of Environmental Consequences}

An environmental consequence of E2 was assigned because a discharge of approximately $7,040 \mathrm{~kg}$ of powder was judged to be a significant onsite discharge.

\subsection{Assignment of Risk Bins}

Table 2-1 summarizes the frequency, consequence, and risk bin assignments for the release of dried radioactive waste representative accidents. The assignment of risk bins is derived from the consequences and estimated frequency of the accident. The onsite radiological risk bin is III due to the "low" consequences and "unlikely" frequency. The risk bin for the onsite toxicological receptor is I because the consequence is "high" and the estimated frequency is "unlikely." The risk bin for the offsite toxicological receptor is III because the consequence is "low" and the estimated frequency is "unlikely." 


\subsubsection{Associated Hazardous Conditions}

The results of the risk binning process for the hazardous conditions covered by the representative accidents in this document are contained within the hazard evaluation database. The hazard evaluation database includes the basis for each consequence and frequency. Consensus was reached by the risk binning team that all the represented hazardous conditions were bounded by the representative accidents.

The risk binning team considered the process design as well as the conservatisms in the analysis when assigning consequence and frequency bins to the other represented hazardous conditions. The results are presented with the representative accidents in Table 2-1, and are discussed below.

\subsubsection{Lid Fails to Seal to the In-Container Vitrification Container Due to Misalignment or Sealing Lip Damage}

\subsubsection{Scenario}

This scenario postulates that dried material could leak from the ICV container during processing if the seal between the container and the Ancillary Waste Transfer Enclosure (AWTE) were compromised.

\subsubsection{Frequency Determination}

This condition would likely be due to human error. Therefore, a frequency bin of "anticipated" was assigned.

\subsubsection{Consequence Determination}

No quantification of consequences of this scenario was made. Leakage, if any, from the gap between the container and the AWTE is expected to be bounded by the scenarios previously discussed. Therefore, the consequence bins assigned were assigned based on the spills and falls of dried waste from beneath the dryer outlet representative accident. The onsite radiological and the offsite toxicological bins are "low." The onsite toxicological consequence bin is qualitatively assigned to be "moderate" because it is not expected that the release rate of material from the leak between the ICV and the AWTE would be as high as for the dryer outlet release accident.

\subsubsection{Drop and Spill of Dried Waste From ICV Container Due to Interrupted Melt (Less Than 3 m High)}

\subsubsection{Accident Scenario}

This condition can occur when a non-compliant batch is received from the waste dryer causing the melt to stop and the ICV container must be moved from the melt area. The top of the ICV container is at a height of approximately $11 \mathrm{ft}$. This spill is assumed to occur when the container 


\section{RPP-20725 REV 2}

tips over or is dropped during movement of the ICV to the container storage area. The release is therefore assumed to occur at a height within $3 \mathrm{~m}$ of the ground. Conservative assumptions include, three dryer batches involved in the spill, and none of the waste being vitrified. The waste drop would result in the generation of dust as well as a small amount of material suspension due to air movement.

\subsubsection{Frequency Determination}

This event could be the result of one of several possible causes, including vehicle impacts, a seismic event, manufacturing defects, or installation errors. The design basis earthquake has a return period that puts it in the "unlikely" frequency range. Failures due to manufacturing defects or installation errors are judged to be "unlikely" because the equipment will be new, and all systems will be tested during startup with non-hazardous materials prior to operating with the tank waste. Therefore, the event was assigned a frequency bin of "unlikely."

\subsubsection{Consequence Determination}

To provide an estimate of the radiological and toxicological consequences, scoping calculations were performed and are documented in Appendix B. The accident scenario, without controls, assumes that during transport of the ICV container to the storage area, there is a breach in the container due to events identified above. The dried waste is spilled on the ground or other hard surface.

The release is assumed to contain three complete waste dryer batches $(7,040 \mathrm{~kg})$ of dried waste mixture. The dried waste is assumed to contain no liquids.

The radiological ULDs and toxicological SOFs for the dried waste (stream 8) waste were taken from RPP-CALC-30596. The atmospheric dispersion factors are from RPP-13482, and the airborne release fraction, respirable fraction, and airborne release rate are from DOE-HDBK-3010-94.

A complete list of the analysis assumptions is presented in Table 2-8. The table includes, for each assumption, information on the potential effect of changes in the assumption, and the need to evaluate or protect the assumption.

\subsubsection{Assignment of Consequence Bins}

Although the evaluation of consequences was intended to be qualitative, consequences were estimated by scoping calculations as shown in Appendix B.

Tables 2-9 and 2-10 compare the calculated consequences of the representative accident to the radiological and toxicological risk evaluation guidelines. The onsite radiological consequences for the fall or drop of dried waste from an ICV container (less than $3 \mathrm{~m}$ high) were below the $25 \mathrm{rem}$ "moderate" consequence guideline; therefore, they were assigned to a consequence bin of "low." The onsite toxicological consequences were above the "high" consequence guideline. Therefore, they were assigned to the "high" consequence bin. The offsite toxicological consequences are below the moderate consequence guidelines, thus they were assigned to a "low" consequence bin. 
RPP-20725 REV 2

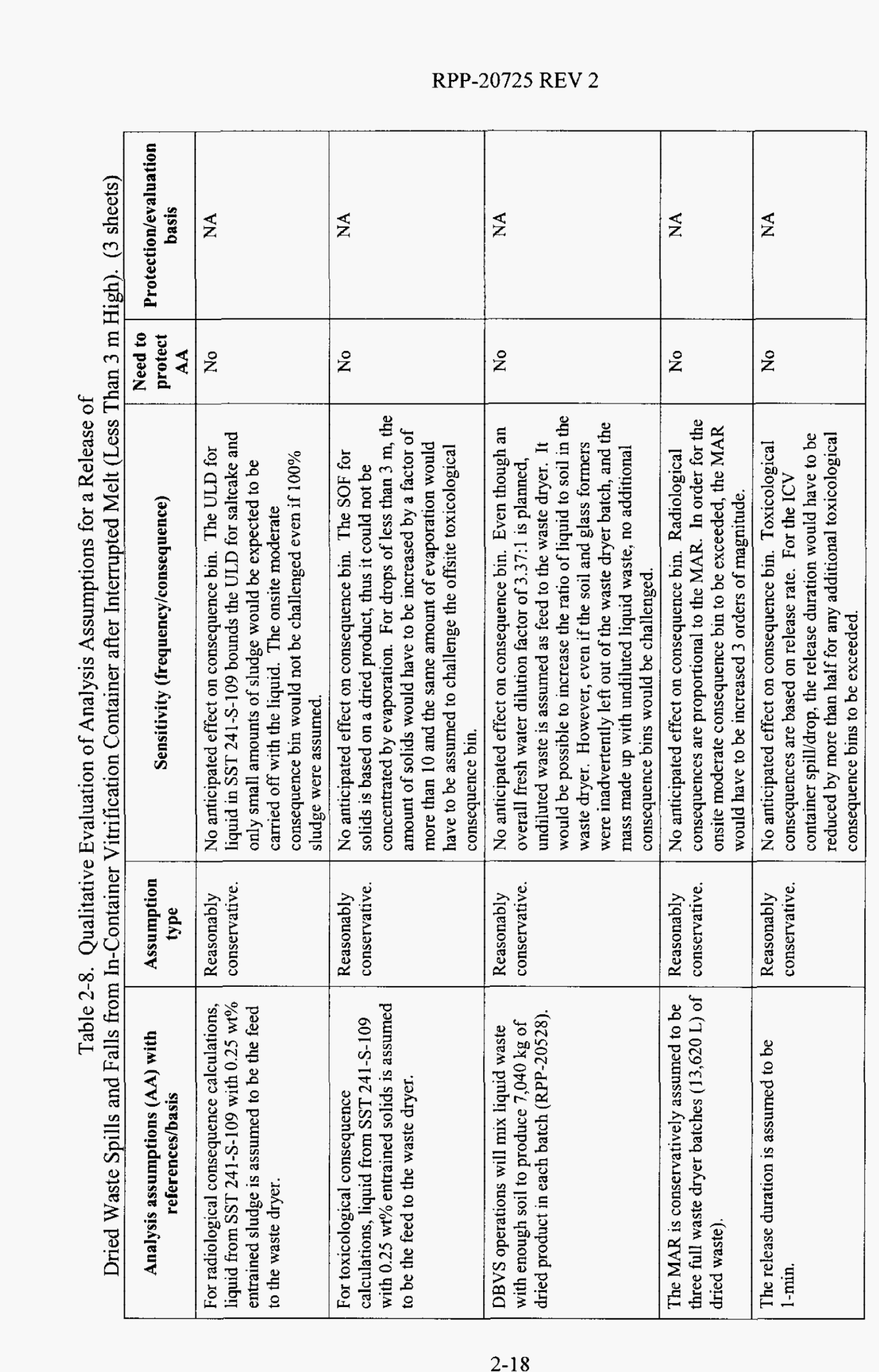

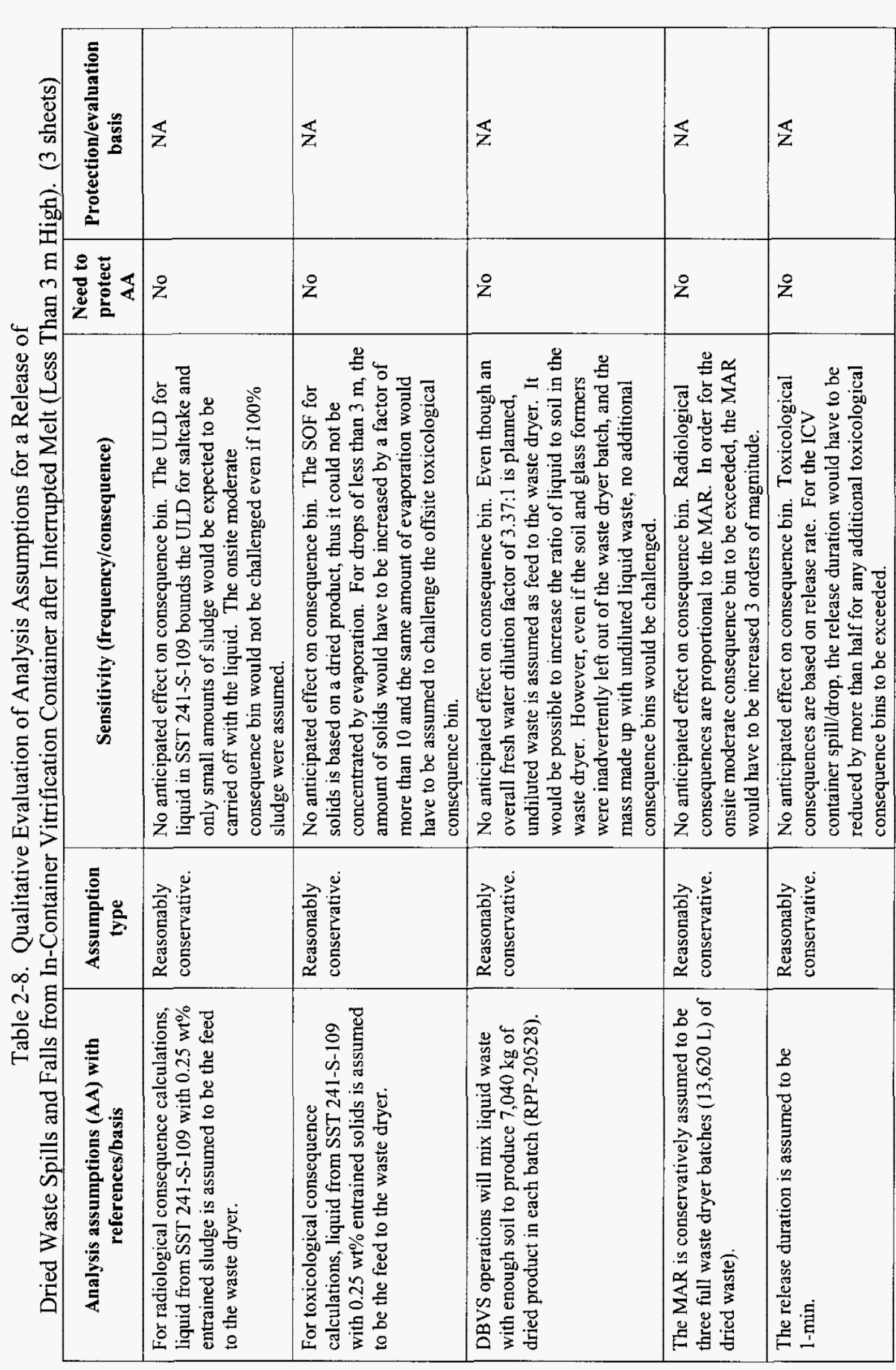

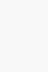

\section{RPP-20725 REV 2}
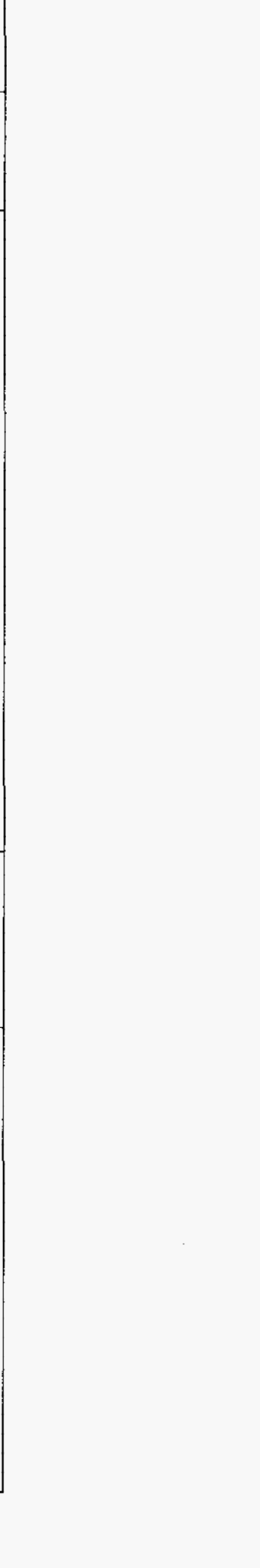


\begin{tabular}{|c|c|c|c|c|c|c|}
\hline 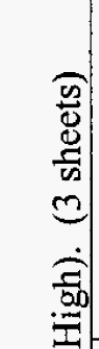 & 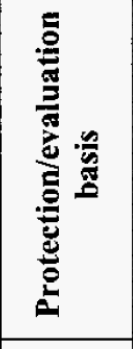 & $\overleftrightarrow{z}$ & $\mathbb{Z}$ & $\overleftarrow{z}$ & $\mathbb{z}$ & 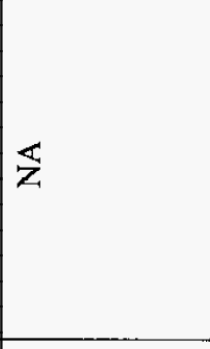 \\
\hline 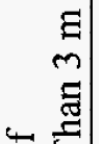 & 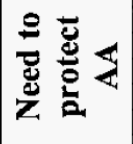 & 之 & $\stackrel{0}{z}$ & z & z & 2 \\
\hline 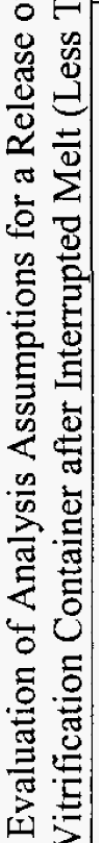 & 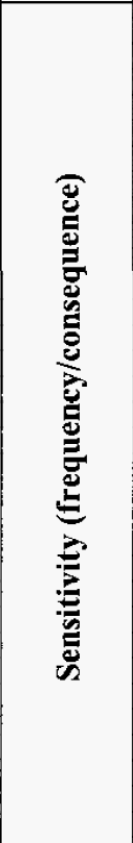 & 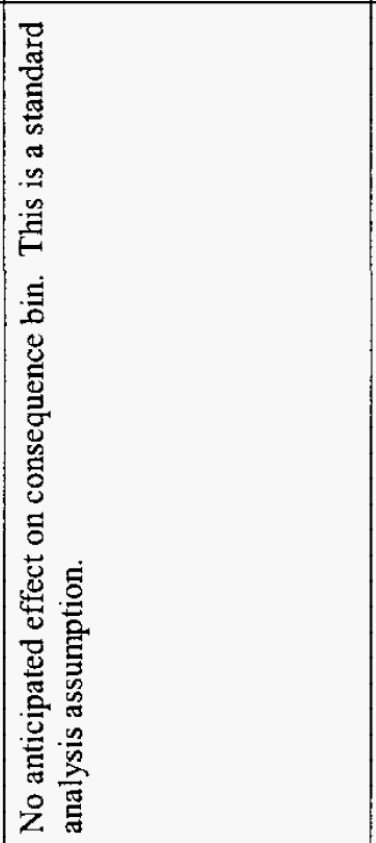 & 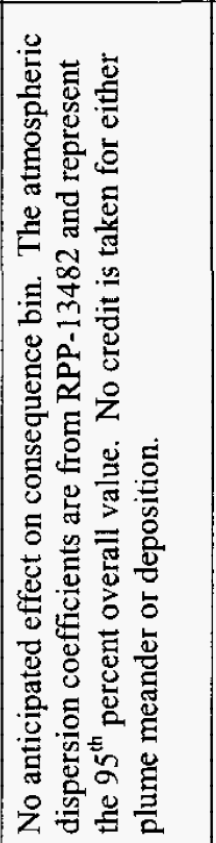 & 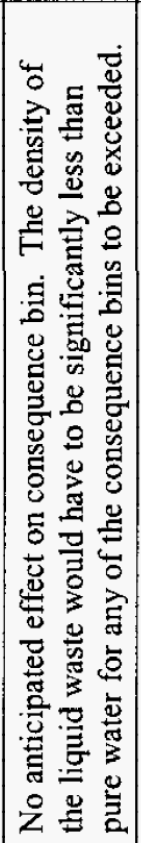 & 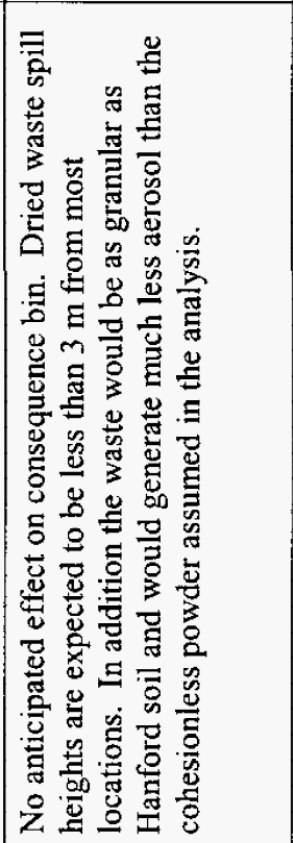 & 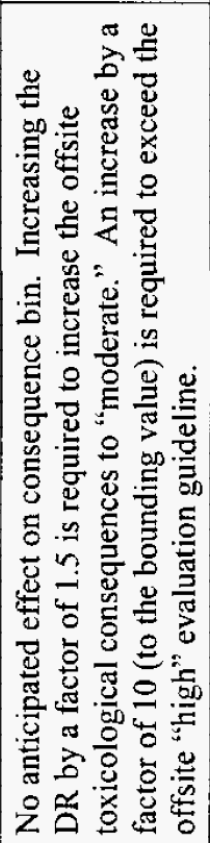 \\
\hline 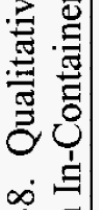 & 高 & 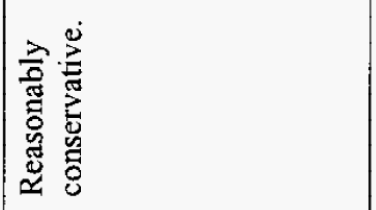 & 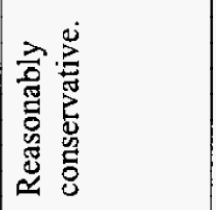 & 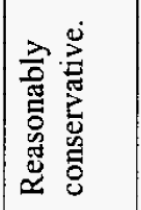 & 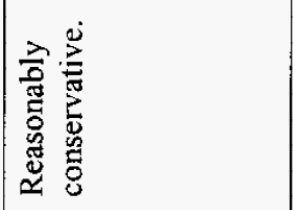 & 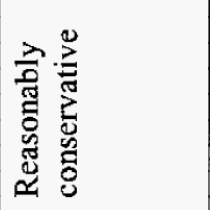 \\
\hline 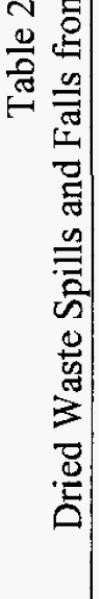 & 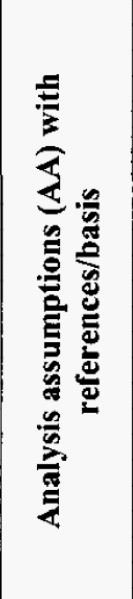 & 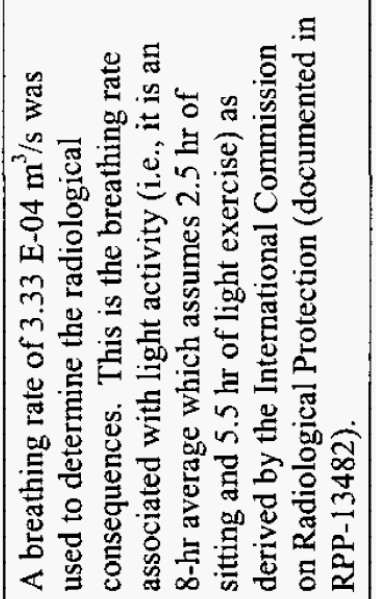 & 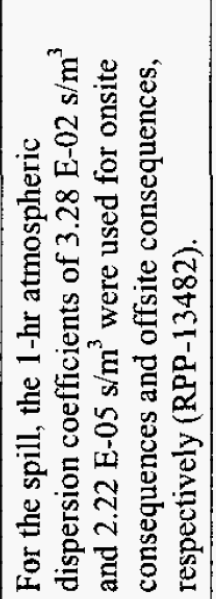 & 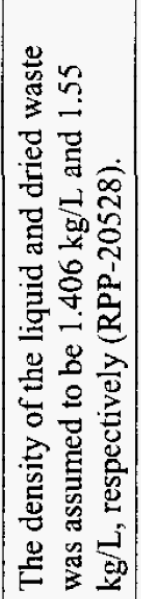 & 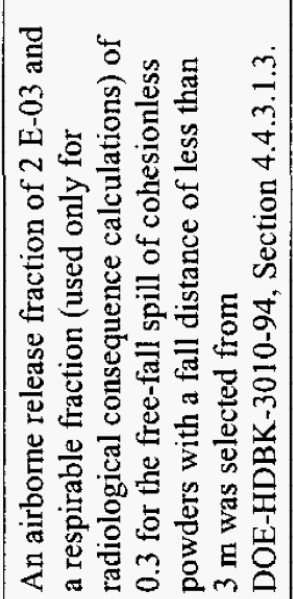 & 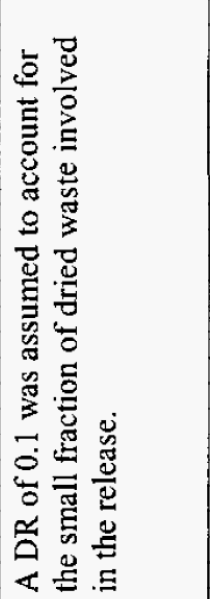 \\
\hline
\end{tabular}

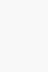

\section{RPP-20725 REV 2}

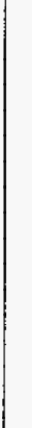

.

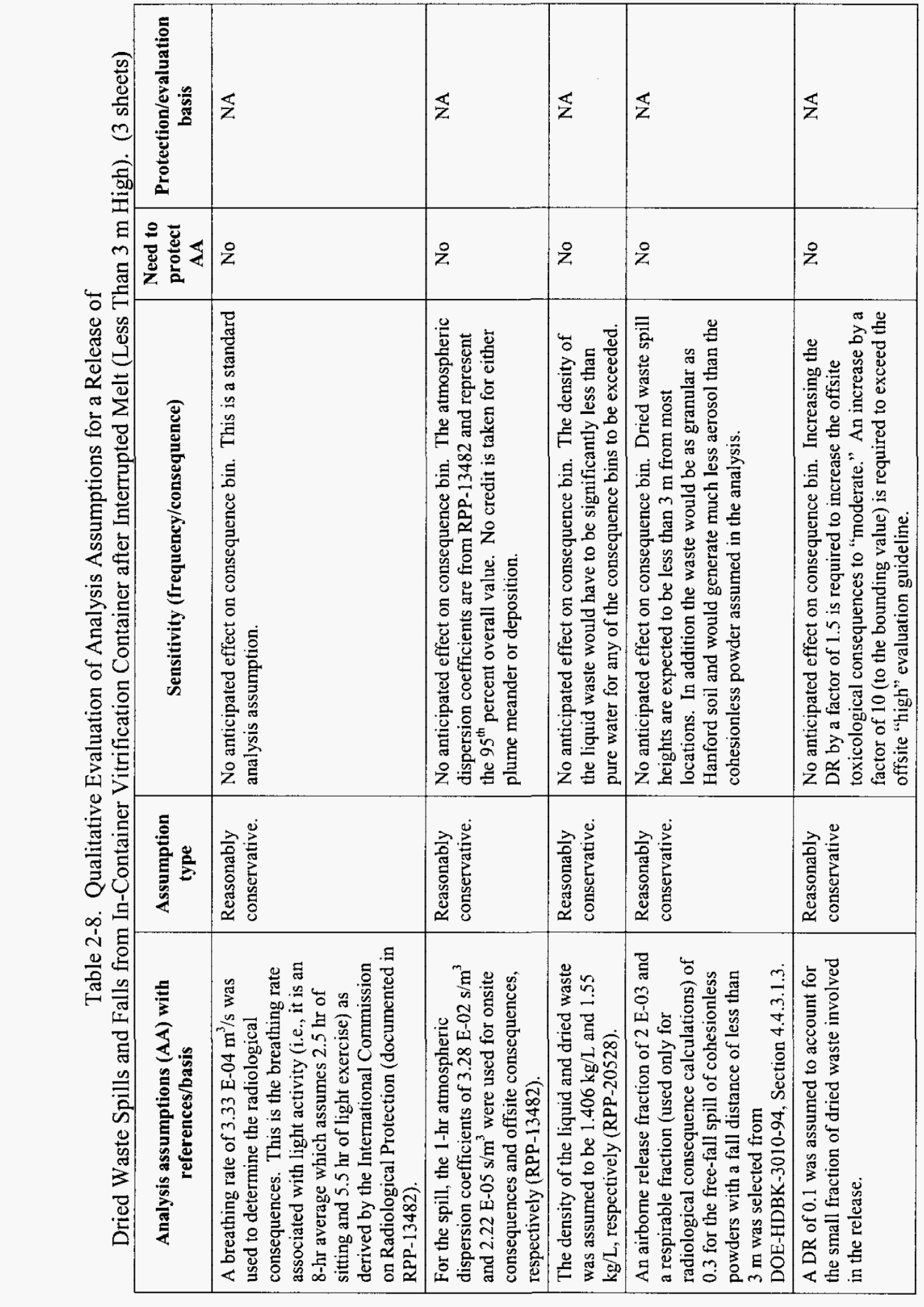

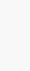


RPP-20725 REV 2

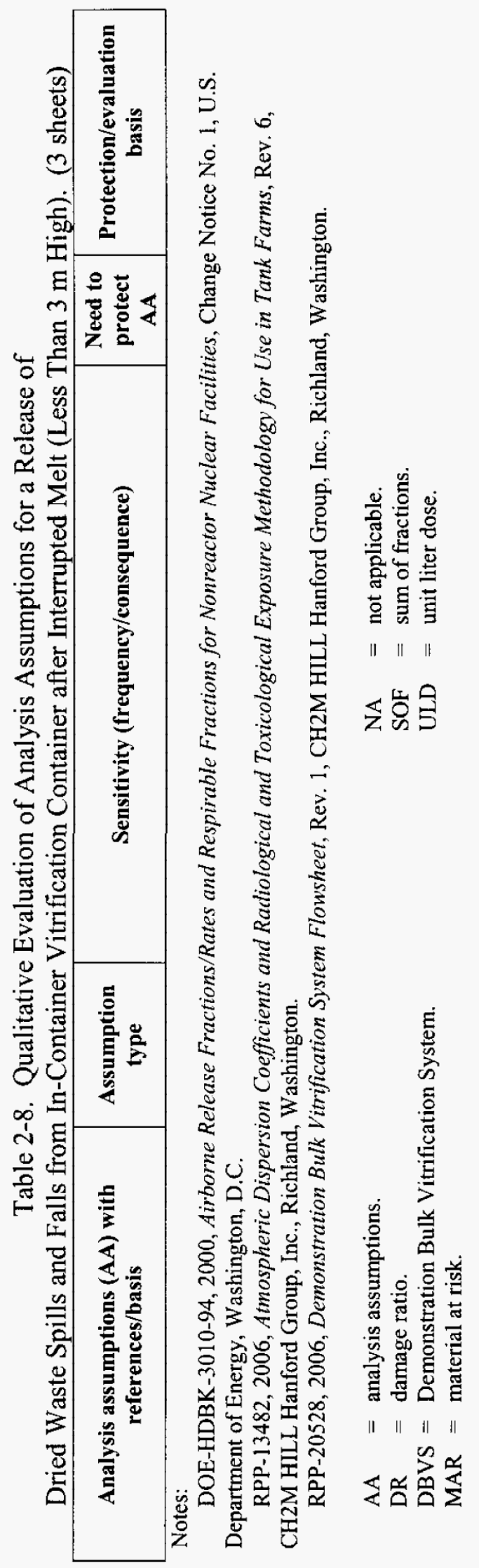


Table 2-9. Summary of Onsite Radiological Consequences Without Controls for the Spill of Dried Waste from In-Container Vitrification Container (Less Than $3 \mathrm{~m}$ High).

\begin{tabular}{|c|c|c|c|}
\hline \multirow{2}{*}{ Case } & \multicolumn{2}{|c|}{ Onsite radiological consequences } \\
\cline { 2 - 4 } & $\begin{array}{c}\text { Calculated dose } \\
\text { (rem) }\end{array}$ & $\begin{array}{c}\text { Moderate } \\
\text { consequence } \\
\text { guideline } \\
\text { (rem) }\end{array}$ & $\begin{array}{c}\text { High consequence } \\
\text { guideline } \\
\text { (rem) }\end{array}$ \\
\hline $\begin{array}{l}\text { Spill and drop of dried waste from } \\
\text { ICV container (less than } 3 \mathrm{~m} \text { high) }\end{array}$ & $2.1 \mathrm{E}-02$ & 25 & 100 \\
\hline
\end{tabular}

Note:

$\mathrm{ICV}=$ In-Container Vitrification.

Table 2-10. Summary of Toxicological Consequences Without Controls for the Spill of Dried Waste from In-Container Vitrification Container

(Less Than $3 \mathrm{~m}$ High).

\begin{tabular}{|c|c|c|c|c|c|c|c|c|}
\hline \multirow{4}{*}{ Case } & \multicolumn{8}{|c|}{ Toxicological Consequences } \\
\hline & \multicolumn{4}{|c|}{ Onsite } & \multicolumn{4}{|c|}{ Offsite } \\
\hline & \multicolumn{2}{|c|}{$\begin{array}{c}\text { Moderate } \\
\text { consequence }\end{array}$} & \multicolumn{2}{|c|}{$\begin{array}{c}\text { High } \\
\text { consequence }\end{array}$} & \multicolumn{2}{|c|}{$\begin{array}{c}\text { Moderate } \\
\text { consequence }\end{array}$} & \multicolumn{2}{|c|}{$\begin{array}{c}\text { High } \\
\text { consequence }\end{array}$} \\
\hline & SOF & Guideline & SOF & Guideline & SOF & Guideline & SOF & Guideline \\
\hline $\begin{array}{l}\text { Spill and drop } \\
\text { of dried waste } \\
\text { from ICV } \\
\text { container (less } \\
\text { than } 3 \mathrm{~m} \text { high) }\end{array}$ & 144.4 & 1 & 9.2 & 1 & 0.65 & 1 & -- & 1 \\
\hline
\end{tabular}

Note:

$\mathrm{ICV}=$ In-Container Vitrification.

$\mathrm{SOF}=$ sum of fractions.

\subsubsection{Assignment of Environmental Consequences}

An environmental consequence of $\mathrm{E} 2$ was assigned because a discharge of approximately $7,040 \mathrm{~kg}$ of powder was judged to be a significant onsite discharge.

\subsubsection{Assignment of Risk Bins}

Table 2-1 summarizes the frequency, consequence, and risk bin assignments for the release of dried radioactive waste representative accidents. The assignment of risk bins is derived from the consequences and estimated frequency of the accident. The onsite radiological risk bin is III due to the "low" consequences and "unlikely" frequency. The risk bin for the onsite toxicological receptor is I because the consequence is "high" and the estimated frequency is "unlikely." The risk bin for the offsite toxicological receptor is III because the consequence is "low" and the estimated frequency is "unlikely." 


\subsection{FILTRATION FAILURE SCENARIOS}

During several Process and Hazard/Operability Analysis and control decision meetings, consensus was obtained on the assignment of frequencies, consequences, and controls. Scoping calculations were performed to support the assignment of consequence bins. These calculations are presented in Appendix B. The risk binning results for the filtration failure scenarios are shown in Table 2-11.

Table 2-11. Risk Binning Results for Dried Waste Releases Due to Filtration Failures.

\begin{tabular}{|c|c|c|c|c|c|c|c|c|}
\hline \multirow[b]{2}{*}{ Postulated accident } & \multirow[b]{2}{*}{ Frequency } & \multicolumn{4}{|c|}{ Consequences } & \multicolumn{3}{|c|}{ Risk bin } \\
\hline & & 宸 & 胥 & 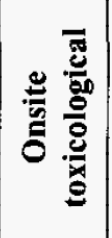 & 昰 & 焉 & 总 & 冚 \\
\hline $\begin{array}{l}\text { Release of radioactive and hazardous } \\
\text { material from DBVS OGTS filters due to } \\
\text { over temperature event. Includes } 8 \text {-hr } \\
\text { unfiltered release through failed filters } \\
\text { (representative accident } 3 \text { ). }\end{array}$ & A & $\mathrm{L}$ & $\mathrm{L}$ & M & E1 & III & III & I \\
\hline $\begin{array}{l}\text { Release of radioactive and hazardous } \\
\text { material from DBVS OGTS filters due to } \\
\text { over pressure event. Includes } 8 \text {-hr } \\
\text { unfiltered release through failed filters } \\
\text { (associated accident). }\end{array}$ & A & $\mathrm{L}$ & $\mathrm{L}$ & M & E1 & III & III & I \\
\hline $\begin{array}{l}\text { Unfiltered release of radioactive and } \\
\text { hazardous material from DBVS OGTS due } \\
\text { to failure of filters or seals. The onsite and } \\
\text { offsite receptors are assumed to be exposed } \\
\text { for } 8 \mathrm{hr} \text { (associated accident). }\end{array}$ & A & $\mathrm{L}$ & $\mathrm{L}$ & M & E1 & III & III & I \\
\hline $\begin{array}{l}\text { Notes: } \\
\text { A = anticipated. } \\
\text { DBVS }=\text { Demonstration Bulk Vitrificati } \\
\text { E1= localized discharges of hazardous }\end{array}$ & $\begin{array}{l}\text { System. } \\
\text { terial. }\end{array}$ & $\begin{array}{l}\text { M } \\
\text { DGTS }\end{array}$ & $\begin{array}{l}=\text { low } \\
=\text { moder } \\
=\text { Off-Ga }\end{array}$ & $\begin{array}{l}\text { ate. } \\
\text { as Treatr }\end{array}$ & ent $s$ & stem. & & \\
\hline
\end{tabular}

\subsubsection{Representative Accident 3: Filter Failure Due to High Temperature}

\subsubsection{Accident Scenario}

In this scenario the OGTS HEPA filters (and prefilters) fail due to high temperature causing a partial release of the maximum waste loading on the filters. This is followed by an $8-\mathrm{hr}$ unfiltered release from the DBVS at the maximum exhauster flow rate. 


\section{RPP-20725 REV 2}

\subsubsection{Frequency Determination}

The HEPA over temperature accident may occur as a result of a ventilation system heater failure or an external fire. These potential accident initiators are assigned an "anticipated" frequency.

\subsubsection{Consequence Determination}

To provide an estimate of the radiological and toxicological consequences, scoping calculations were performed and are documented in Appendix B. The accident scenario, without controls, assumes that during operation of the DBVS the HEPA filters fail due to a high temperature event. The waste is released to the atmosphere.

For purposes of this analysis, a bounding case was assumed that takes no credit for the OGTS and assumes maximum continuous releases from the ICV. The highest particulate release rates from the ICV occur during the loading process where dried waste is being added to the vitrification container from a dry waste receiver. During this operation, a fraction of the dried feed is expected to enter the off-gas system as a fine dust. During normal operation, this dust will be caught by sintered metal filters, recycled back to the waste dryer, and then back to the vitrification container feed. For the bounding filtration failure analysis, it is assumed that the dust effluent from the vitrification container feed operation proceeds directly to the final HEPA filters for the duration of the accident. The HEPA filters are assumed to be plugged with dust from the vitrification container feed operation.

The maximum loading on each HEPA filter is assumed to be $1 \mathrm{~L}$ of solids based on filter plugging (i.e. high $\triangle \mathrm{P}$ and low flow rate). The load on each of the two prefilters is assumed to be $10 \%$ of the load on a HEPA filter and one HEPA load of waste is assumed to be plated out or trapped within the ductwork, heater, etc. upstream of the filters. The total load of waste within the particulate filter system (two prefilters, four HEPA filters, and one duct) subject to release is therefore assumed to be 5.2 HEPA loads or $5.2 \mathrm{~L}$ of dried solids.

Any ${ }^{129}$ I associated with the dust coming out of the vitrification container loading operation will be trapped by the HEPA filters. The gaseous ${ }^{129}$ I loading on the activated carbon filter will originate primarily in the melting process. No credit is taken for removal of ${ }^{129} \mathrm{I}$ by the off-gas scrubber system when estimating the loading on the carbon filter. Although the ${ }^{129} \mathrm{I}$ emissions from the vitrification operation are minor compared to the other components, the ${ }^{129} \mathrm{I}$ loading on the carbon filter is treated separately in the calculation of filter release due to high temperature. In the release due to high temperature case the carbon filter is assumed to release $100 \%$ of its load of ${ }^{129} \mathrm{I}$ (as opposed to $0.01 \%$ for the particulates on the HEPA filters) and so the ${ }^{129} \mathrm{I}$ has some importance. The total ${ }^{129} \mathrm{I}$ release per container processed with no credit for the off-gas scrubber system is $2.15 \mathrm{E}-03 \mathrm{Ci}$ (stream 21 in Appendix H of RPP-20528, Demonstration Bulk Vitrification System Flowsheet). The carbon filter is assumed to be loaded with a total ${ }^{129} \mathrm{I}$ inventory equivalent to the releases from the vitrification of 100 containers of waste (approximately twice the number expected to be processed), or $2.15 \mathrm{E}-01 \mathrm{Ci}$. [2.15 E-3/ ICV x 100 ICVs]

The radiological ULDs and toxicological SOF multipliers for the dried waste (stream 8) were taken from RPP-CALC-30596. The atmospheric dispersion factors are from RPP-13482, and the 


\section{RPP-20725 REV 2}

airborne release fraction, respirable fraction, and airborne release rate are from DOE-HDBK-3010-94.

A complete list of the analysis assumptions is presented in Table 2-12. The table includes, for each assumption, information on the potential effect of changes in the assumption, and the need to evaluate or protect the assumption. 
RPP-20725 REV 2

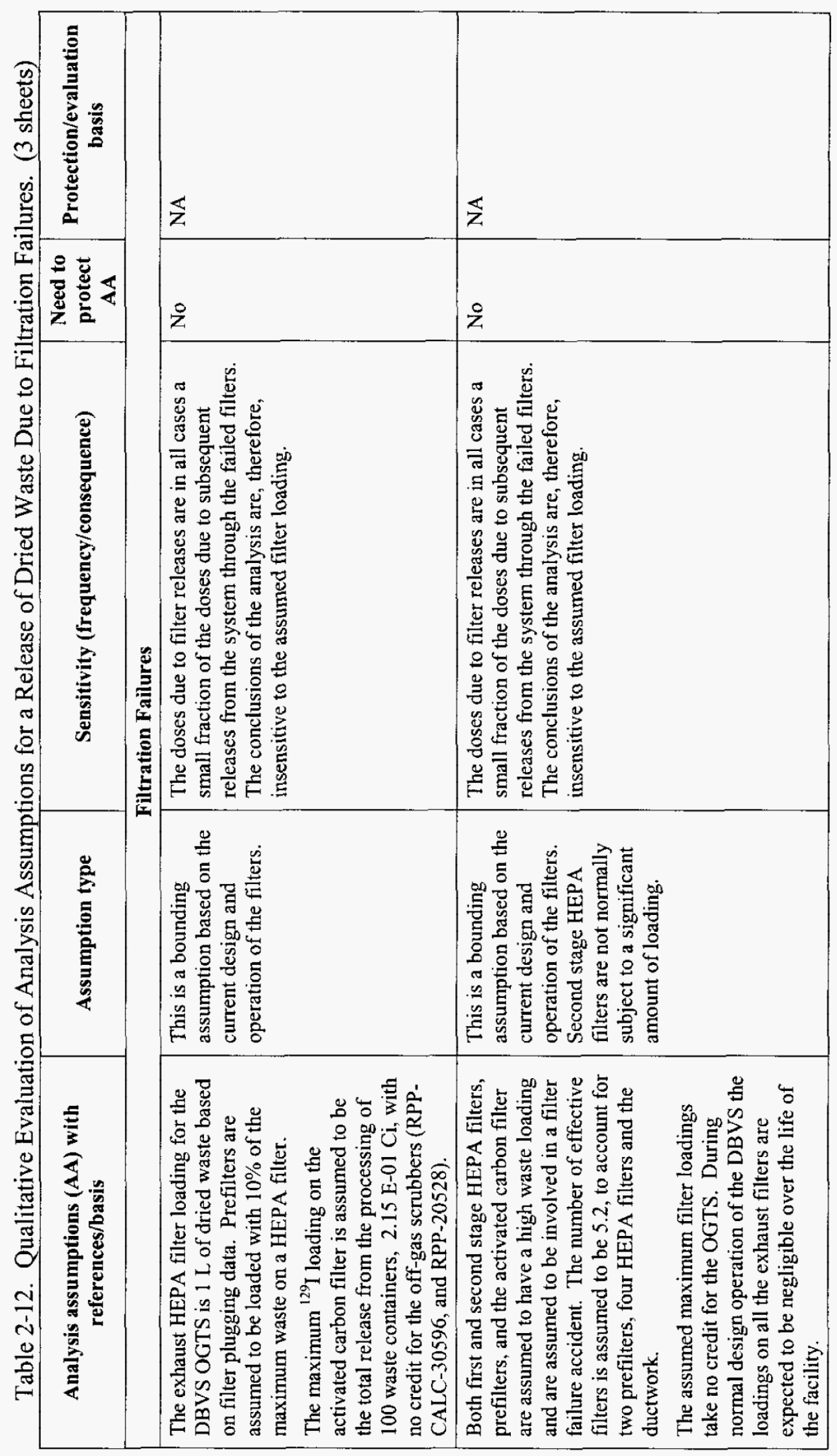


RPP-20725 REV 2

\begin{tabular}{|c|c|c|c|c|c|c|}
\hline & 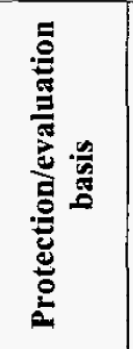 & \multicolumn{2}{|l|}{$\mathbb{z}$} & 飞 & $\mathbb{z}$ & $\overleftarrow{z}$ \\
\hline & 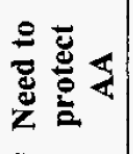 & \multicolumn{2}{|l|}{ z } & $z$ & Z & z \\
\hline 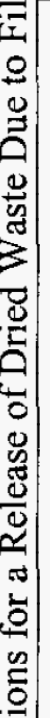 & 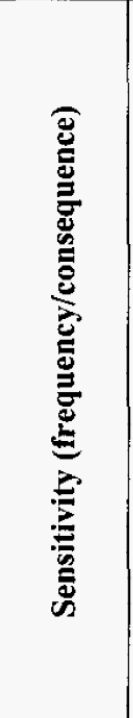 & \multicolumn{2}{|l|}{ 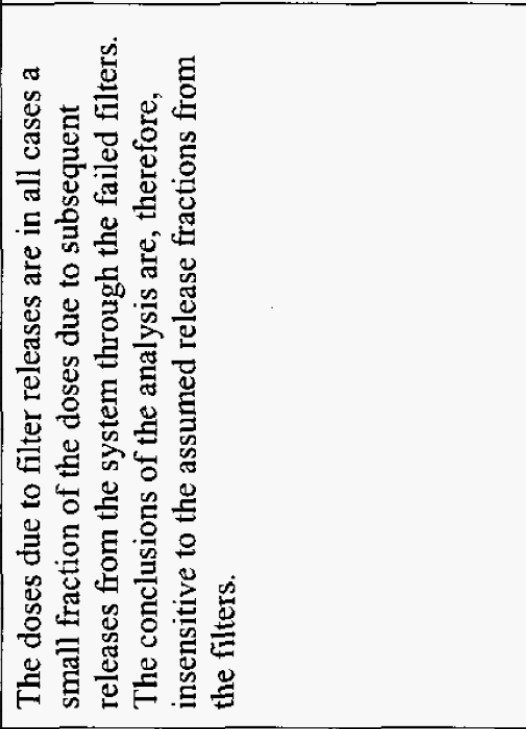 } & 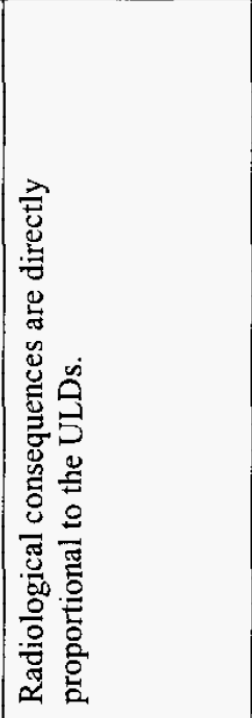 & 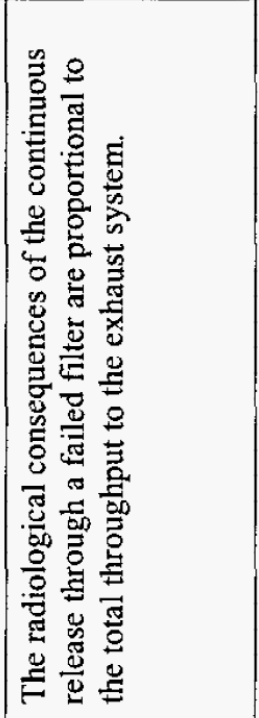 & 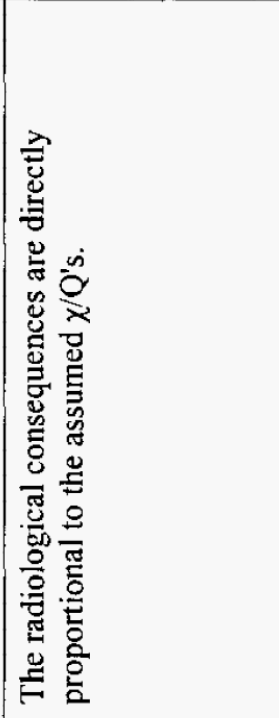 \\
\hline 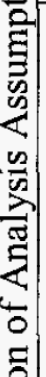 & 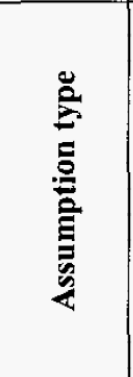 & \multicolumn{2}{|l|}{ 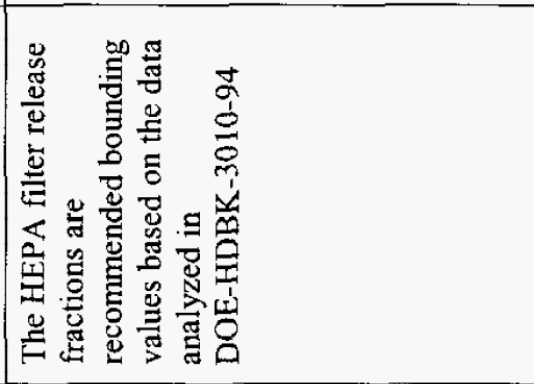 } & 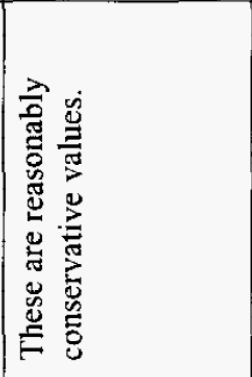 & 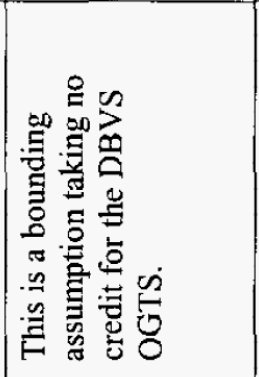 & 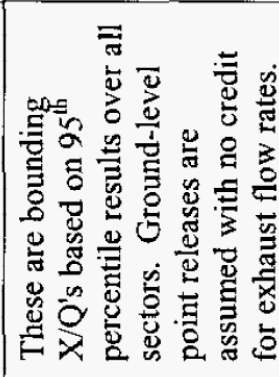 \\
\hline 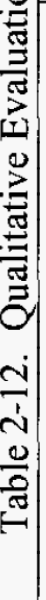 & 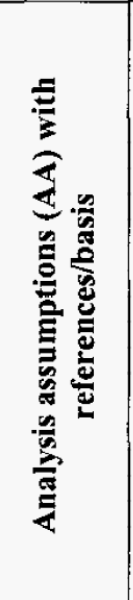 & 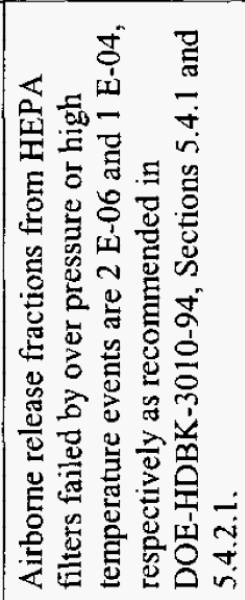 & 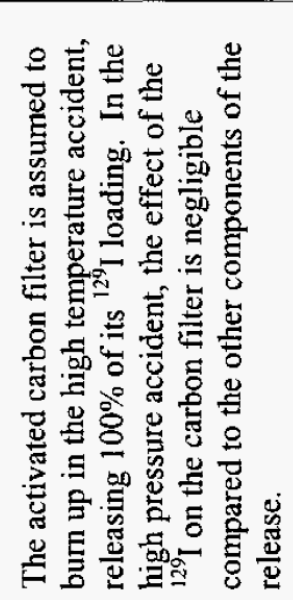 & 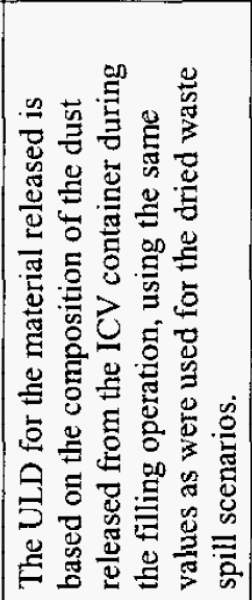 & 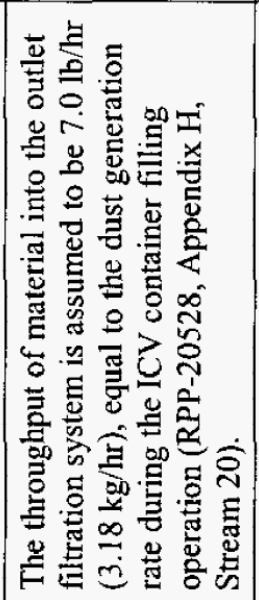 & 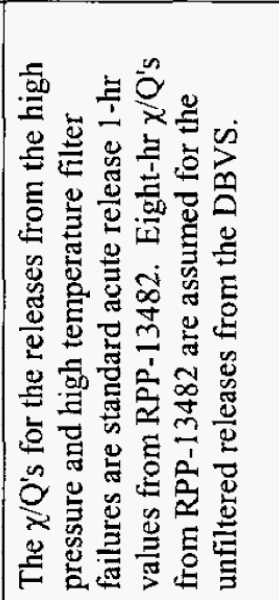 \\
\hline
\end{tabular}

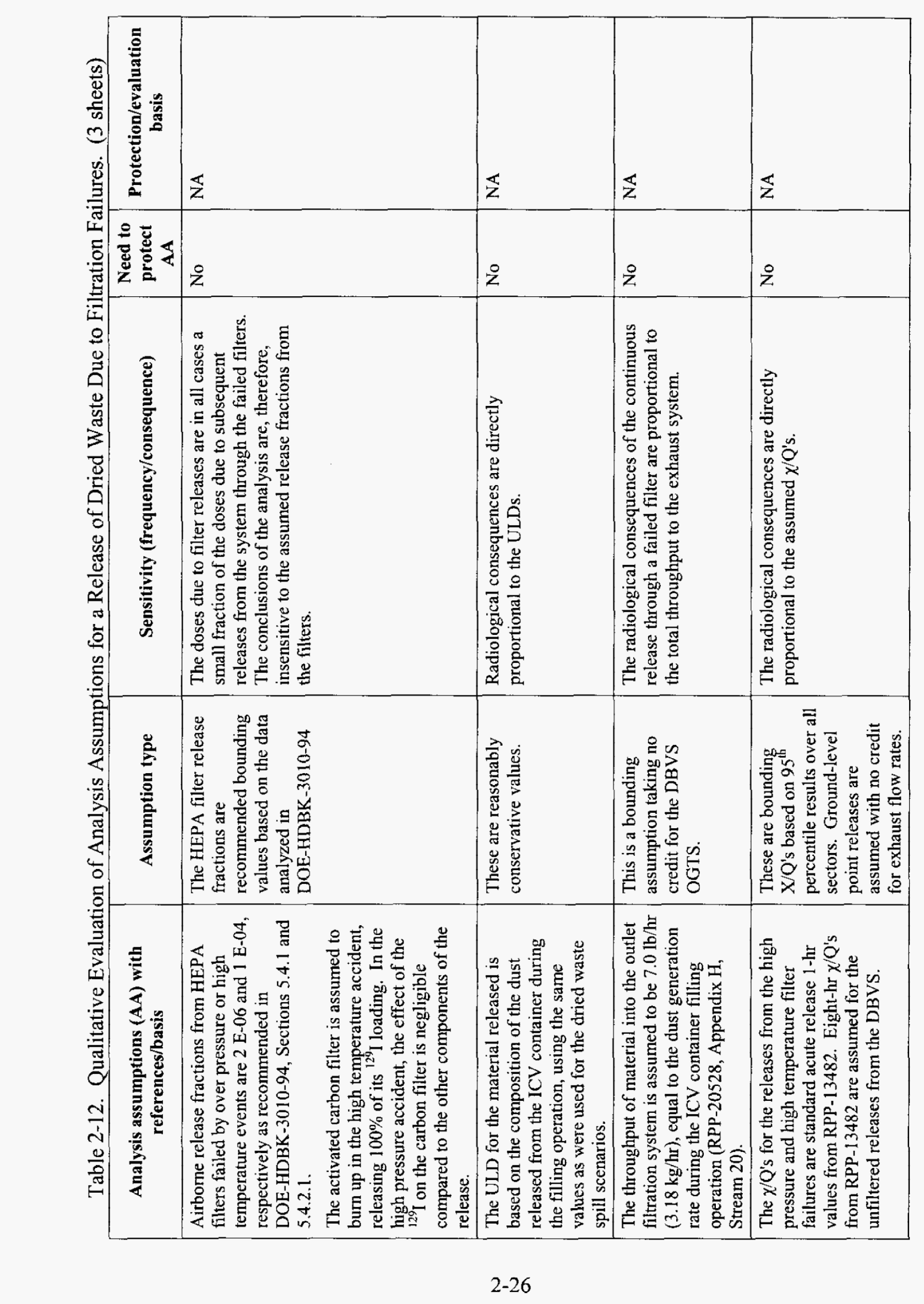

(1)

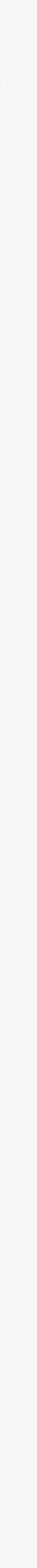

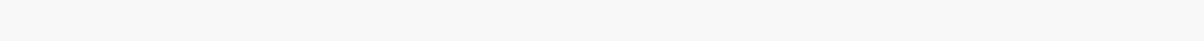

$$
\text { . }
$$

\section{RPP-20725 REV 2}
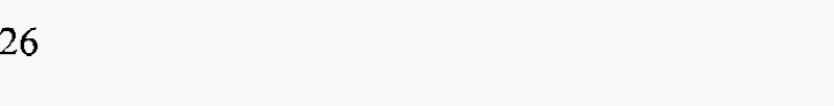


\section{RPP-20725 REV 2}

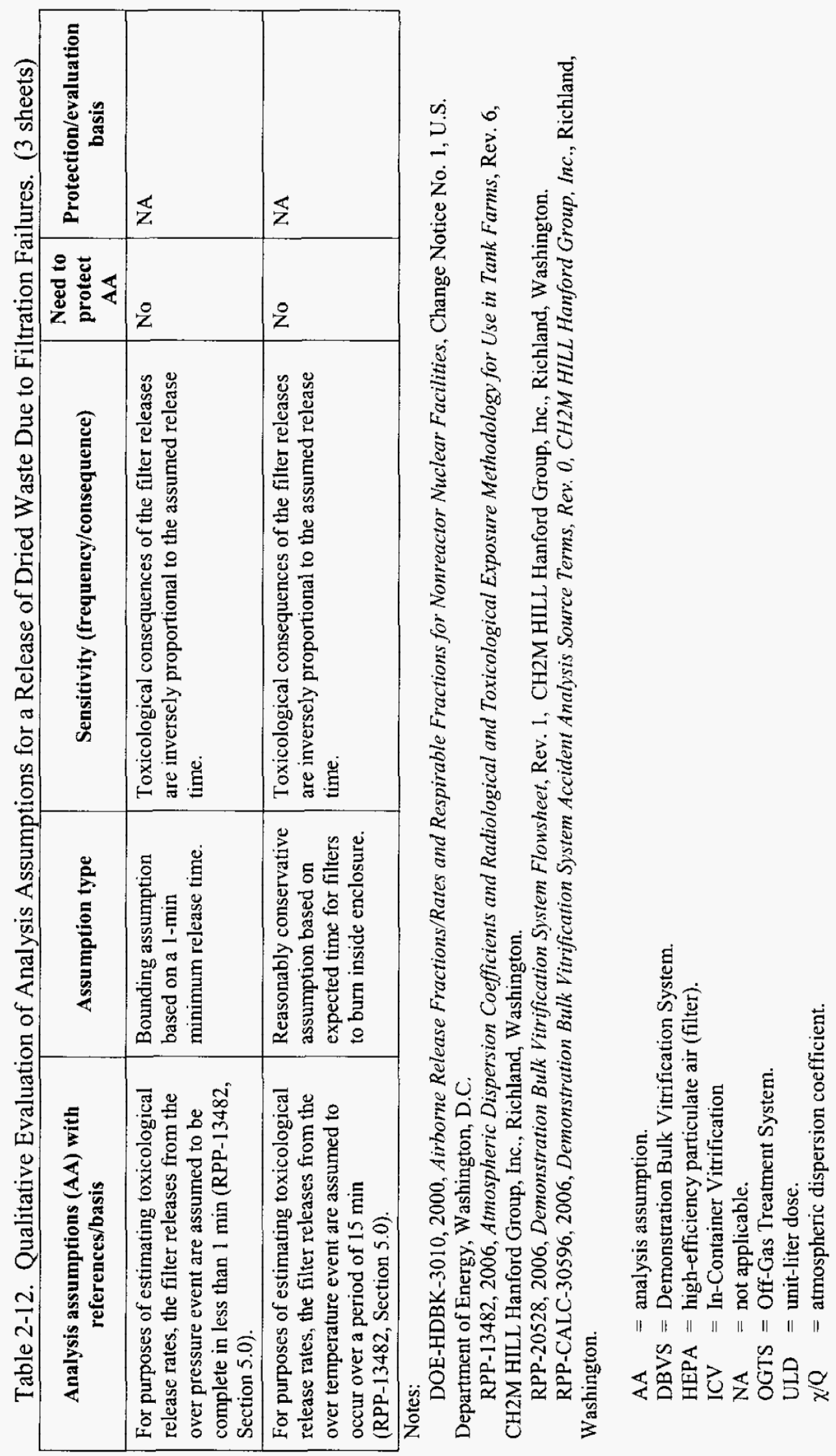




\section{RPP-20725 REV 2}

\subsection{Assignment of Consequence Bins}

Although the evaluation of consequences was intended to be qualitative, the consequences were estimated with scoping calculations as shown in Appendix B.

Tables 2-16 and 2-17 compare the calculated consequences of the representative accident to the radiological and toxicological risk evaluation guidelines. The onsite radiological consequences for the release from the OGTS filtration failure were below the $25 \mathrm{rem}$ "moderate" consequence guideline; therefore, they were assigned to a consequence bin of "low." The offsite toxicological consequences were below the "moderate" consequence guideline and were assigned to a consequence bin of "low." The onsite toxicological consequences were above the "moderate" consequence guideline but below the "high" consequence guideline, thus they were assigned to a "moderate" consequence bin.

Table 2-13. Summary of Onsite Radiological Consequences Without Controls for the Filtration Failure Representative Accident.

\begin{tabular}{|l|c|c|c|}
\hline \multirow{2}{*}{ Case } & \multicolumn{2}{|c|}{ Onsite radiological consequences } \\
\cline { 2 - 4 } & $\begin{array}{c}\text { Calculated dose } \\
\text { (rem) }\end{array}$ & $\begin{array}{c}\text { Moderate } \\
\text { consequence } \\
\text { guideline } \\
\text { (rem) }\end{array}$ & $\begin{array}{c}\text { High consequence } \\
\text { guideline } \\
\text { (rem) }\end{array}$ \\
\hline $\begin{array}{l}\text { Filter Failure Due to High } \\
\text { Temperature }\end{array}$ & $5.0 \mathrm{E}-01$ & 25 & 100 \\
\hline
\end{tabular}

Table 2-14. Summary of Toxicological Consequences Without Controls for the Filtration Failure Representative Accident.

\begin{tabular}{|c|c|c|c|c|c|c|c|c|}
\hline \multirow{4}{*}{ Case } & \multicolumn{8}{|c|}{ Toxicological Consequences } \\
\hline & \multicolumn{4}{|c|}{ Onsite } & \multicolumn{4}{|c|}{ Offsite } \\
\hline & \multicolumn{2}{|c|}{$\begin{array}{l}\text { Moderate } \\
\text { consequence }\end{array}$} & \multicolumn{2}{|c|}{$\begin{array}{c}\text { High } \\
\text { consequence }\end{array}$} & \multicolumn{2}{|c|}{$\begin{array}{c}\text { Moderate } \\
\text { consequence }\end{array}$} & \multicolumn{2}{|c|}{$\begin{array}{c}\text { High } \\
\text { consequence }\end{array}$} \\
\hline & SOF & Guideline & SOF & Guideline & SOF & Guideline & SOF & Guideline \\
\hline $\begin{array}{l}\text { Filter Failure } \\
\text { Due to High } \\
\text { Temperature }\end{array}$ & 1.6 & 1 & 0.10 & 1 & $7.2 \mathrm{E}-03$ & 1 & $1.1 \mathrm{E}-03$ & 1 \\
\hline
\end{tabular}

Note:

SOF $=$ sum of fractions.

\subsection{Assignment of Environmental Consequences}

An environmental consequence of E1 was assigned because it is expected that the filtration failure releases will be localized. 


\section{RPP-20725 REV 2}

\subsection{Assignment of Risk Bins}

Table 2-11 summarizes the frequency, consequence, and risk bin assignments for the filtration failure representative accident. The assignment of risk bins is derived from the consequences and estimated frequency of the accident. The risk bin for the onsite radiological and offsite toxicological receptors is III because the consequences are "low" and the estimated frequency is "anticipated." The risk bin for the onsite toxicological receptor is I because the consequence is "moderate" and the estimated frequency is "anticipated."

\subsubsection{Associated Hazardous Conditions}

The results of the risk binning process for the hazardous conditions covered by the representative accidents in this document are contained within the hazard evaluation database. The hazard evaluation database includes the basis for each consequence and frequency. Consensus was reached by the risk binning team that all the represented hazardous conditions were bounded by the representative accidents.

The risk binning team considered the process design as well as the conservatisms in the analysis when assigning consequence and frequency bins to the other represented hazardous conditions. The results are presented with the representative accident in Table 2-11, and are discussed below.

\subsubsection{Filter Failure Due to High Pressure}

\subsubsection{Accident Scenario}

The HEPA filters fail due to an overpressure event causing a partial release of the maximum waste loading on the filters. This is followed by an 8-hr unfiltered release from the DBVS at the maximum exhauster flow rate.

\subsubsection{Frequency Determination}

The HEPA over pressure accident is similar to an event believed to have occurred in the past when a filter became saturated with moisture and was subsequently damaged when the ventilation fans were turned on. The unfiltered release path could occur from several causes, including human error during filter maintenance. Therefore, the event is assigned a frequency of "anticipated."

\subsubsection{Consequence Determination}

The consequences of the filter failure due to overpressure are the same as the consequences of filter failure due to high temperature. The 8-hr release following filter failure dominates the consequences. Therefore, the onsite radiological consequences and the offsite toxicological consequences were assigned to the "low" consequence bin. The offsite toxicological consequences were assigned to the "moderate" consequence bin. 


\subsubsection{Eight-hour Unfiltered Release}

\subsubsection{Scenario}

An 8-hr unfiltered release occurs at the maximum exhauster flow rate due to an error during filter maintenance, gross leakage around a misaligned filter, or damage to the ductwork. This release is also included in the first two scenarios, but in this third scenario there is no release from the filters themselves.

\subsubsection{Frequency Determination}

The unfiltered release path could occur from several causes, including human error during filter maintenance. Therefore, the event was assigned to the "anticipated" frequency bin.

\subsubsection{Consequence Determination}

The consequences of the two previously discussed filter failure scenarios were dominated by the portion of the consequences that came from the 8-hr unfiltered release following the filter failure event. Therefore, the consequences of $8 \mathrm{hr}$ of leakage around the filter are essentially the same as the consequences of the filter failure scenarios. The onsite radiological and the offsite toxicological consequences are in the "low" consequence bin. The onsite toxicological consequences are in the "moderate" consequence bin. 


\subsection{CONTROL SELECTION}

During several Process and Hazard/Operability Analysis and control decision meetings, consensus was obtained on the assignment of frequencies, consequences, and controls for each of the release of dried waste accidents. The meeting attendees represented a wide range of expertise in the areas of engineering, licensing, and operations. The control decision results for scenarios considered in this document are shown in this section. Selected controls for the representative and represented release of dried waste accidents are discussed in detail below.

\subsection{SELECTED CONTROLS FOR THE RELEASE OF DRIED RADIOACTIVE WASTE ACCIDENTS}

\subsubsection{Control Selection}

The proposed controls were discussed and evaluated by the group. Control decision criteria are established in the following documents:

- Title 10, Code of Federal Regulations, Part 830, Subpart B, "Nuclear Safety Management" (10 CFR 830)

- DOE-STD-3009-94

- DOE G 421.1-2, Implementation Guide for Use in Developing Documented Safety Analyses to Meet Subpart B of 10 CFR 830

- DOE G 423.1-1, Implementation Guide for Use in Developing Safety Requirements

- Klein and Schepens (2003).

The control decision preference can be summarized as follows:

1. Preventive controls over mitigative

2. Passive controls over active control

3. Engineering controls over administrative controls

4. Controls with the highest reliability

5. Controls closest to the hazard

6. Controls with the lowest implementation and maintenance costs.

A consensus was reached based on the judgment of the participants to use a passive confinement strategy based on the preferences listed above. The passive confinement strategy maximizes the use of passive and engineered controls over active and administrative controls. 
RPP-20725 REV 2

\subsubsection{Selected Control Strategies}

\subsubsection{Representative Accident 1: Failure of Pneumatic Transfer Line During Transfer of Dried Waste}

For the release of dried waste from the DWTS during pneumatic transport scenario, the estimated offsite toxicological consequences are "low" (Risk Bin III). The estimated onsite (100-m facility worker) radiological consequence is "low" (Risk Bin III). The estimated worstcase onsite toxicological consequence is "high" $>$ temporary emergency exposure limit (TEEL)-3, (Risk Bin I). Controls (i.e., safety SSCs, TSRs) are required because the potential onsite toxicological risk of a release of dry material from this accident was assigned to Risk Bin I.

The overall control strategy for the pneumatic transfer accident is to confine the dried waste material and filter any effluent (e.g., sintered metal filters high-efficiency gas absorbers (HEGA), HEPA filters) prior to release. Negative pressure confinement is normally provided for the dryer, the DWTS, the ICV container, and OGTS. The safety control strategy, which does not credit this negative pressure confinement or filtration, is to passively confine the dried waste, and release any actively confined dried waste effluent from a tall exhaust stack to increase atmospheric dispersion. Specific controls assigned to each hazardous condition requiring controls are described in Appendix A of RPP-23429, Preliminary Documented Safety Analysis for the Demonstration Bulk Vitrification System.

The safety-significant SSCs and TSRs that have been designated for this accident, including their safety functions are described in Table 3.3.2.3.5-2 and Table 3.3.2.3.5-3 of RPP-23429. Several safety-significant SSCs work together with TSRs to address dried waste release accidents.

\subsubsection{Small Fire-Initiated Fall of Dried Waste from Greater than $3 \mathbf{~ m}$.}

Application of controls for dried waste release accident scenarios initiated by fires are addressed in RPP-30361.

\subsubsection{Representative Accident 2: Spills and Falls from Beneath the Dryer Outlet $(>3 \mathrm{~m})$.}

For the greater than $3 \mathrm{~m}$ release from beneath the dryer outlet, the estimated offsite toxicological consequences are "low" (Risk Bin III). The estimated onsite (100-m facility worker) radiological consequence is "low" (Risk Bin III). The estimated worst-case onsite toxicological consequence is "high" > TEEL-2, (Risk Bin I). Controls (i.e., safety SSCs, TSRs) are required because the potential onsite toxicological risk of a release of dry material from this accident was assigned to Risk Bin I.

The overall control strategy for the release from beneath the dryer outlet accident is to prevent the dried waste material release. Safety-significant passive confinement is provided by the dryer, DWTS, ICV containers, OGTS confinement structures, and Off-gas exhaust stack. To reduce the frequency of breaches in these confinement boundaries these confinement structures are designated safety-significant. To ensure the dryer is able to provide confinement, a TSR is specified to ensure waste dryer openings are closed and seals are inspected/tested. Specific 


\section{RPP-20725 REV 2}

controls assigned to each hazardous condition requiring controls are described in Appendix A of RPP-23429.

The safety-significant SSCs and TSRs that have been designated for this accident, including their safety functions are described in Table 3.3.2.3.5-2 and Table 3.3.2.3.5-3 of RPP-23429. Several safety-significant SSCs work together with TSRs to address dried waste release accidents.

\subsubsection{Representative Accident 3: Filtration Failures}

For the high-temperature caused filter failure leading to release of dried waste from the OGTS during vitrification operations, the estimated offsite toxicological consequences are "low" (Risk Bin III). The estimated onsite (100-m facility worker) radiological consequence is "low" (Risk Bin III). The estimated worst-case onsite toxicological consequence is "moderate" > TEEL-2 (Risk Bin I). Controls (i.e., safety SSCs, TSRs) are required because the potential onsite toxicological risk of a release of dry material from the OGTS due to filtration failure was assigned to Risk Bin I.

This accident is mitigated by ensuring that the OGTS outlet is sufficiently elevated that atmospheric dispersion will have diluted the release before it reaches the ground. Specific controls assigned to each hazardous condition requiring controls are described in Appendix A of RPP-23429.

The safety-significant SSCs and TSRs that have been designated for this accident, including their safety functions are described in Table 3.3.2.3.5-2 and Table 3.3.2.3.5-3 of RPP-23429. Several safety-significant SSCs work together with TSRs to address dried waste release accidents.

Other hazardous conditions represented by the filter failure due to high temperature representative accident include filter failure due to high pressure and unfiltered releases due to improper filter installation or damaged ductwork. The control strategy for the representative accident is also applicable to the represented accidents. No additional controls were identified.

\section{Facility Worker Hazards and Controls}

The above hazard evaluation also determined the potential consequences to facility workers from dried material release accidents. The postulated risk bin I and II release of dried material scenarios addressed previously have the potential to cause significant facility worker consequences, but are acceptably prevented or mitigated by the selected controls. However, one additional hazardous condition with "low" consequences to the onsite worker and offsite public was identified as having potentially significant facility worker hazards. This hazardous condition concerned a release of dried radioactive and other hazardous materials from the waste dryer or DWTS due to hydraulic fire in waste dryer ISO freight container. Since the initiator is a fire, application of controls for this hazardous condition are addressed in RPP-30361. 
RPP-20725 REV 2

This page intentionally left blank.

\author{
This page intentionally left blank.
}


RPP-20725 REV 2

\subsection{REFERENCES}

10 CFR 830, "Nuclear Safety Management," Code of Federal Regulations, as amended.

DOE G 421.1-2, 2001, Implementation Guide For Use in Developing Documented Safety Analyses To Meet Subpart B of 10 CFR 830, U.S. Department of Energy, Washington, D.C.

DOE G 423.1-1, 2001, Implementation Guide For Use In Developing Technical Safety Requirements, U.S. Department of Energy, Washington, D.C.

DOE-HDBK-3010-94, 2000, Airborne Release Fractions/Rates and Respirable Fractions for Nonreactor Nuclear Facilities, Change Notice No. 1, U.S. Department of Energy, Washington, D.C.

DOE-STD-3009-94, 2006, Preparation Guide for U.S. Department of Energy Nonreactor Nuclear Facility Documented Safety Analyses, Change Notice No. 3, U.S. Department of Energy, Washington, D.C.

Klein, K. A., and R. J. Schepens, 2003, "Replacement of Previous Guidance Provided by RL and ORP," (letter 03-ABD-0047/0300462 to E. K. Thomson, Fluor Hanford Inc., and E. S. Aromi, CH2M HILL Hanford Group, Inc., February 4), U.S. Department of Energy, Richland Operations Office, Richland, Washington.

PNNL-13757-1, 2002, Characterization of Vadose Zone Sediment: Uncontaminated RCRA Borehole Core Samples and Composite Samples, Pacific Northwest National Laboratory, Richland, Washington.

RPP-10773, 2002, Compressed Gas Accident Parametric Consequence Analysis, Rev. 0, CH2M HILL Hanford Group, Inc., Richland, Washington.

RPP-13482, 2006, Atmospheric Dispersion Coefficients and Radiological and Toxicological Exposure Methodology for Use in Tank Farms, Rev. 6, CH2M HILL Hanford Group, Inc., Richland, Washington.

RPP-20528, 2006, Demonstration Bulk Vitrification System Flowsheet, Rev. 1, CH2M HILL Hanford Group, Inc., Richland, Washington.

RPP-23429, 2006, Preliminary Documented Safety Analysis for the Demonstration Bulk Vitrification System, Rev. 1, CH2M HILL Hanford Group, Inc., Richland, Washington.

RPP-23479, Preliminary Documented Safety Analysis for the Contact-Handled Transuranic Mixed (CH-TRUM) Waste Facility, Rev. 0, CH2M HILL Hanford Group, Inc., Richland, Washington. 
RPP-20725 REV 2

RPP-30361, 2007, Technical Basis for DBVS Fires and Explosions, Rev. 1, CH2M HILL Hanford Group, Inc., Richland, Washington.

RPP-CALC-30596, 2006, Demonstration Bulk Vitrification System Accident Analysis Source

Terms, Rev. 0, CH2M HILL Hanford Group, Inc., Richland, Washington. 
RPP-20725 REV 2

APPENDIX A

RISK BINNING/CONTROL ALLOCATION MEETING ATTENDEES 


\section{RPP-20725 REV 2}

This page intentionally left blank.

A-ii 
RPP-20725 REV 2

\section{APPENDIX A}

\section{RISK BINNING/CONTROL ALLOCATION MEETING ATTENDEES}

\section{CONTROL DECISION MEETING ATTENDANCE}

Meeting Subject: Release of Dried Waste during DBVS Operations

Meeting Date: 9/28/04

\begin{tabular}{|l|l|l|l|}
\hline Name & Organization & Telephone & Mail Stop \\
\hline Kevin Sandgren & CH2M HILL NS\&L & $372-0374$ & S7-90 \\
\hline Mark Hasty & $\begin{array}{l}\text { CH2M HILL Closure } \\
\text { Project }\end{array}$ & $373-9378$ & \\
\hline David Shuford & CH2M HILL DBVS & $372-0703$ & T4-67 \\
\hline K. J. McCracken & DMJM & $375-7875$ & \\
\hline Dick Whitehurst & DMJM & $375-7883$ & \\
\hline Richard DeBusk & CH2M HILL - Safety & $372-1155$ & \\
\hline J. W. Ficklin & CH2M HILL Fac Ops & $373-3527$ & S7-90 \\
\hline John Harris & CH2M HILL NS\&L & $372-1237$ & \\
\hline Mark Lucas & AMEC & $942-1114$ & \\
\hline Lloyd McClure & AMEC & $942-1292$ & S7-12 \\
\hline Lawrence J. Kripps & CH2M HILL & $376-1061$ & \\
\hline George Janicek & CH2M HILL - DA & $376-2225$ & \\
\hline D. W. Hamilton & CH2M HILL & $376-2425$ & \\
\hline J. Stephens & AMEC & $368-7578$ & \\
\hline S. D. Kozlowski & CH2M HILL & $373-1360$ & \\
\hline Felix Miera & CH2M HILL & $376-2034$ & \\
\hline & & & \\
\hline & & & \\
\hline & & & \\
\hline
\end{tabular}


RPP-20725 REV 2

\section{CONTROL DECISION MEETING ATTENDANCE}

Meeting Subject: Release of Dried Waste during DBVS Operations

Meeting Date: 10/18/04

\begin{tabular}{|l|l|l|}
\hline Name & Organization & Telephone \\
\hline Kevin Sandgren & CH2M HILL NS\&L & $372-0374$ \\
\hline Mark Hasty & CH2M HILL Closure Project & $373-9378$ \\
\hline David Shuford & CH2M HILL DBVS & $372-0703$ \\
\hline K. J. McCracken & DMJM & $375-7875$ \\
\hline Dick Whitehurst & DMJM & $375-7883$ \\
\hline Glyn Jones & AMEC & $250-368-2507$ \\
\hline Tom May & CH2M HILL & $372-2493$ \\
\hline John Harris & CH2M HILL NS\&L & $372-1237$ \\
\hline Mark Lucas & AMEC & $942-1114$ Ext 206 \\
\hline Stephen Primo & CH2M HILL & $373-2031$ \\
\hline Lawrence J. Kripps & CH2M HILL & $376-1061$ \\
\hline George Janicek & CH2M HILL - DA & $376-2225$ \\
\hline D. W. Hamilton & CH2M HILL & $376-2425$ \\
\hline Felix Miera & CH2M HILL & $376-2034$ \\
\hline Mike Grigsby & CH2M HILL & $372-1907$ \\
\hline
\end{tabular}

\section{Meeting Date: $10 / 18 / 04$}


RPP-20725 REV 2

APPENDIX B

SUPPORTING CALCULATIONS 
RPP-20725 REV 2

RPP-20725 REV 2
This page intentionally left blank.

This page intentione

RPP-20725

(n)

$(2$

RPP.202025EV 2

g

-

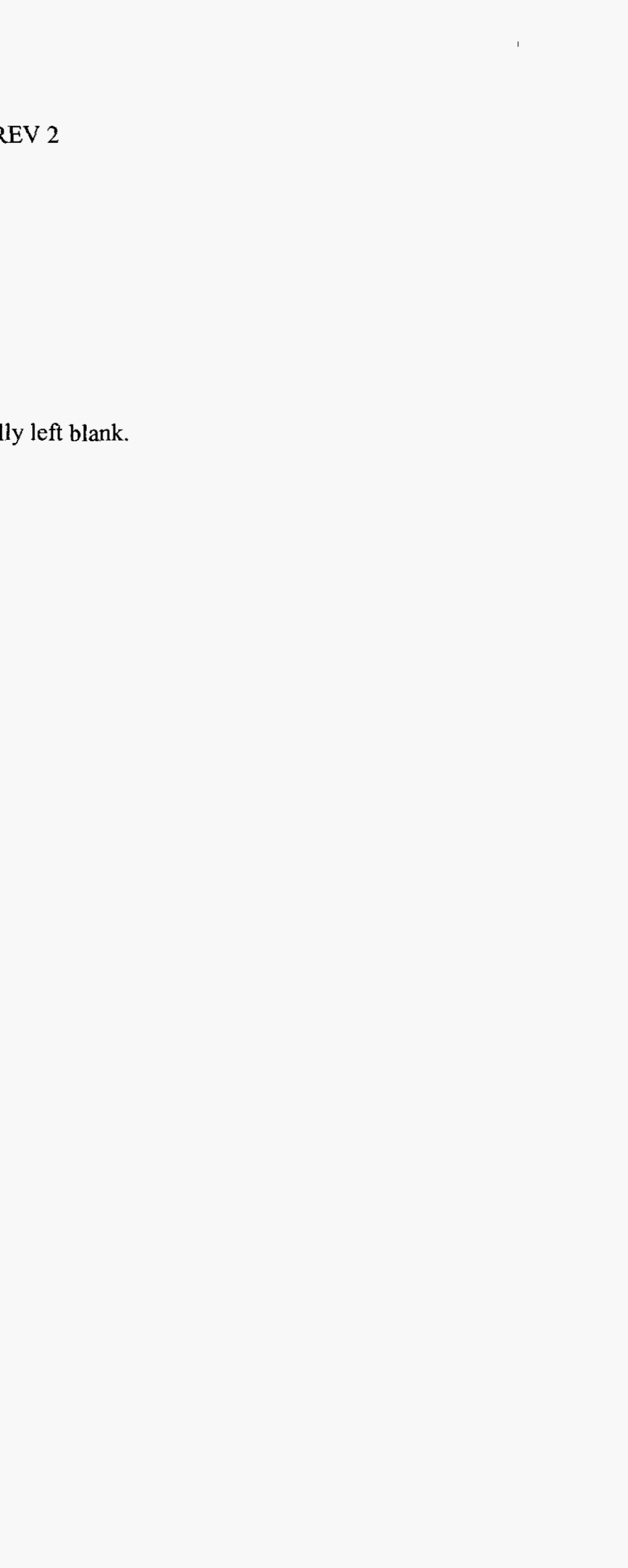


RPP-20725 REV 2

\section{APPENDIX B}

\section{RELEASE OF DRIED WASTE SUPPORTING CALCULATIONS}

\section{B1.0 INTRODUCTION}

The purpose of this appendix is to provide a basis for the qualitative assessment of consequences assigned during the risk binning meeting. Consequences are calculated for the radiological and toxicological exposures resulting from a release of dried radioactive waste during Demonstration Bulk Vitrification System (DBVS) operations. The hazardous conditions include events involving mechanical failures of DBVS components, including the Dried Waste Transfer System (DWTS), In-Container Vitrification (ICV) ${ }^{2}$ Container, Ancillary Waste Transfer Enclosure (AWTE), and Off-Gas Treatment System (OGTS) (e.g., filtration failures).

\section{B2.0 METHODOLOGY}

Radiological dose exposure consequences are calculated consistent with the methodology documented in RPP-13482, Atmospheric Dispersion Coefficients and Radiological/Toxicological Exposure Methodology for Use in Tank Farms. The onsite dose (Equation B-1) is given by:

$$
\text { Dose }=(Q, \text { released })\left(\chi / Q^{\prime}\right)(B R)(U L D, \text { onsite })
$$

where:

$$
\begin{array}{ll}
\text { Dose } & =\text { inhalation dose to receptor, } \mathrm{Sv} \\
Q, \text { released } & =\text { liters of respirable material released to the environment, } \mathrm{L} \\
\chi / Q^{\prime} & =\text { atmospheric dispersion coefficient, } \mathrm{s} / \mathrm{m}^{3} \\
B R & =\text { breathing rate, } \mathrm{m}^{3} / \mathrm{s} \\
U L D & =\text { dose per unit liter of material inhaled as aerosols, } \mathrm{Sv} / \mathrm{L} .
\end{array}
$$

The toxicological consequences were calculated per the methodology established in RPP-13482 for toxicological releases. Toxicological consequences are calculated either with a puff release model or a continuous release model depending on the duration of the release. The puff release model is used for onsite releases with durations $<3.7 \mathrm{~s}$, and for offsite releases with durations $<439 \mathrm{~s}$ (RPP-13482). The events considered in this appendix are modeled as continuous releases.

\footnotetext{
${ }^{2}$ ICV (In-Container Vitrification) is a trademark of AMEC, Inc., London, England.
} 
For a continuous release, the toxicological consequence (Equation B-2) is given by:

$$
\text { Consequence }=(Q / t)\left(\chi / Q^{\prime}\right)(\text { SOF Multiplier })
$$

where:

$$
\begin{array}{ll}
\text { Consequence } & =\text { final sum of fractions value, unitless } \\
Q & =\text { release to the environment, } \mathrm{m}^{3} \\
t & =\text { release time, } \mathrm{s} \\
\chi / Q^{\prime} & =\text { atmospheric dispersion coefficient, } \mathrm{s} / \mathrm{m}^{3} \\
\text { SOF Multiplier } & =\text { sum of fractions multiplier, unitless. }
\end{array}
$$

Determining the quantity of airborne respirable material released to the environment requires knowledge of the volume that is affected and is provided in Equation B-3:

$$
\text { Source Term }(Q)=(M A R)(D R)(A R F)(R F)
$$

where:

$$
\begin{array}{ll}
Q & =\text { source term, } \mathrm{L} \\
M A R & =\text { material at risk, } \mathrm{L} \\
D R & =\text { damage ratio }=1^{*} \\
A R F & =\text { airborne release fraction } \\
R F & =\text { respirable fraction (not applicable to toxicological consequences). }
\end{array}
$$

*Note: A damage ratio of 1.0 is applied for the scenarios in this appendix that do not use a damage ratio.

\section{B3.0 CALCULATIONS}

\section{B3.1 DBVS UNIT LITER DOSE AND SUMS OF FRACTIONS MULTIPLIERS}

Unit liter doses (ULD) and sum of fractions (SOF) multipliers for each Temporary Emergency Exposure Limit (TEEL) are shown in Table B-1. 


\section{RPP-20725 REV 2}

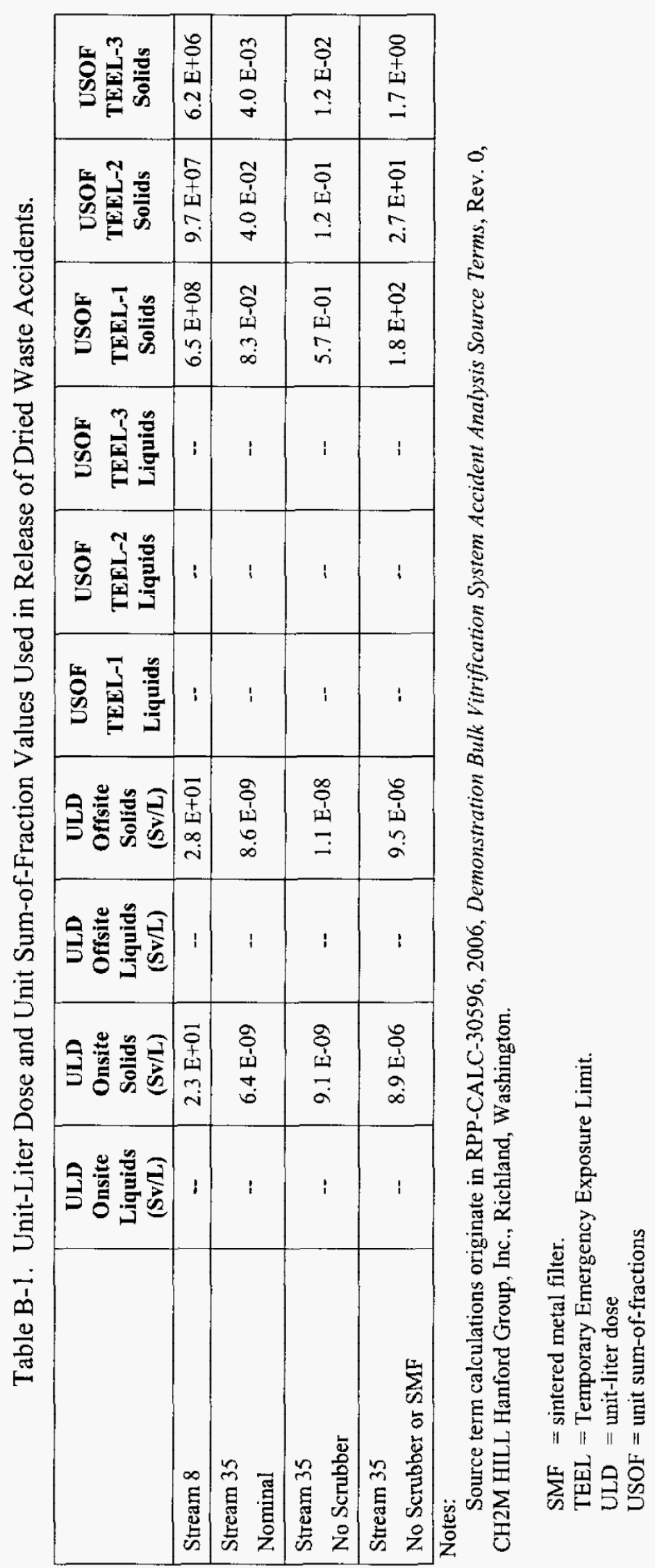


RPP-20725 REV 2

\section{B3.2 CONSEQUENCE CALCULATIONS}

\section{B3.2.1 RELEASE OF PNEUMATICALLY TRANSPORTED DRIED WASTE}

The following assumptions are considered for the failure of the transport system during pneumatic transport of the waste:

- The material acted upon is conservatively assumed to be a full waste dryer batch (4,540 L). [RPP-20528, Demonstration Bulk Vitrification System Flowsheet, App H, Stream 8 (single ICV), $(9.60 \mathrm{E}+03 \mathrm{gal} / \mathrm{ICV} \times 3.785 \mathrm{~L} / \mathrm{gal}) / 8$ batches per ICV)]

- The waste transfer rate is assumed to empty a waste dryer batch $7,040 \mathrm{~kg}$ or $4,540 \mathrm{~L}$ in $1 \mathrm{hr}$ (RPP-20528, Appendix H).

- For the radiological consequence calculation, the relevant $\chi / Q$ 's for ground-level releases are taken from Tables 2-4 and 2-5 of RPP-13482 and are shown in Table B-2. The 1-hr $\chi / Q$ 's (i.e. without plume meander) are used for short duration radiological releases $(<1 \mathrm{hr})$. These $\chi / \mathrm{Q}$ 's are for ground-level, point-source releases. The $\chi / \mathrm{Q}$ 's are $95^{\text {th }}$ percentile worst-case values.

- For the toxicological consequences of the release during pneumatic transport of the dried waste, a 1-hr $\chi / \mathrm{Q}^{\prime}$ with plume depletion is applied, as discussed in Section 2.3.1 of RPP-13482. The consequence analysis for these two cases assumes a particle size distribution taken from measurements of Hanford tank farms backfill soil as given in PNNL-13757-1, Characterization of Vadose Zone Sediment: Uncontaminated RCRA Borehole Core Samples and Composite Samples. The data from the 39.5-ft depth (the shallowest of the levels analyzed from the core) were used for the analysis. The $\chi / \mathrm{Q}$ 's from Tables 2-9 and 2-10 of RPP-13482 were applied for the fraction of the waste in each bin and subsequently summed. Table B-3 shows the particle size distributions and the resulting $\chi / \mathrm{Q}^{\prime} \mathrm{s}$.

- Based on the same tank farm soil characterization data from PNNL-13757-1, about $3 \%$ of the soil's volume has a diameter of $10 \mu \mathrm{m}$ or less (RPP-10773, Compressed Gas Accident Parametric Consequence Analysis). Therefore, the respirable fraction, used for the radiological consequences of the release of pneumatically transported waste is assumed to be 0.03 . 


\section{RPP-20725 REV 2}

Table B-2. Ground-Level Atmospheric Dispersion Coefficients Over All Sectors.

\begin{tabular}{|c|c|c|}
\hline \multirow{2}{*}{ Receptor } & \multicolumn{2}{|c|}{$\chi / \mathbf{Q}^{\prime}\left(\mathbf{s} / \mathbf{m}^{\mathbf{3}}\right)$} \\
\cline { 2 - 3 } & $\mathbf{1 - h r}$ acute & 8-hr acute \\
\hline Onsite & $3.28 \mathrm{E}-02$ & $5.58 \mathrm{E}-03$ \\
\hline Offsite & $2.22 \mathrm{E}-05$ & $7.90 \mathrm{E}-06$ \\
\hline
\end{tabular}

Table B-3. Atmospheric Dispersion Coefficients for Plume Depletion.

\begin{tabular}{|c|c|c|c|c|c|}
\hline \multirow[b]{2}{*}{ Particle size bin } & \multirow[b]{2}{*}{$\begin{array}{l}\text { Fraction of } \\
\text { particles in } \\
\text { the bin }\end{array}$} & \multicolumn{2}{|c|}{ Onsite } & \multicolumn{2}{|c|}{ Offsite } \\
\hline & & $\begin{array}{c}\chi / Q^{\prime} \text { for the } \\
\text { bin } \\
s / \mathbf{m}^{3}\end{array}$ & $\begin{array}{c}\text { Bin } \\
\text { Fraction } \times \text { bin } \\
\chi / Q^{\prime} \\
s / \mathbf{m}^{3}\end{array}$ & $\begin{array}{c}\chi / Q^{\prime} \text { for the } \\
\text { bin } \\
s / m^{3}\end{array}$ & $\begin{array}{c}\text { Bin } \\
\text { Fraction } x \text { bin } \\
\chi / Q^{\prime} \\
s / \mathbf{m}^{3}\end{array}$ \\
\hline Less than 2 & 0.02 & $3.28 \mathrm{E}-02$ & $6.56 \mathrm{E}-04$ & $2.22 \mathrm{E}-05$ & 4.44 E-07 \\
\hline $2-10$ & 0.01 & $2.71 \mathrm{E}-02$ & 2.71 E-04 & $8.86 \mathrm{E}-06$ & $8.86 \mathrm{E}-08$ \\
\hline $10-20$ & 0.01 & $2.11 \mathrm{E}-02$ & $2.11 \mathrm{E}-04$ & $3.62 \mathrm{E}-06$ & $3.62 \mathrm{E}-08$ \\
\hline $20-50$ & 0.06 & $1.38 \mathrm{E}-02$ & $8.28 \mathrm{E}-04$ & $1.61 \mathrm{E}-06$ & $9.66 \mathrm{E}-08$ \\
\hline $50-100$ & 0.25 & $1.43 \mathrm{E}-03$ & $3.58 \mathrm{E}-04$ & $6.28 \mathrm{E}-08$ & $1.57 \mathrm{E}-08$ \\
\hline Greater than 100 & 0.65 & 0.00 & 0.00 & 0.00 & 0.00 \\
\hline Total $\chi / \mathrm{Q}^{\prime}$ & -- & -- & $2.32 \mathrm{E}-03$ & -- & $6.81 \mathrm{E}-07$ \\
\hline
\end{tabular}

\section{B3.2.1.1 Onsite Radiological Consequences}

The onsite dose is found using the methodology in RPP-13482. The dose is given by Equation B-1:

$$
D_{\text {onsite }}=(Q, \text { released })\left(\chi / Q_{\text {onsite }}^{\prime}\right)(B R)\left(U L D_{\text {onsite }}\right)
$$

where:

$$
\begin{aligned}
Q, \text { released } & =\text { liters of respirable material released to the environment (L) } \\
& =M A R \times D R \times A R F \times R F \\
& =(4,540 \mathrm{~L})(1)(1)(0.03) \\
& =136.3 \mathrm{~L} \\
& =\text { onsite atmospheric dispersion coefficient } \\
& =3.28 \mathrm{E}-02 \mathrm{~s}^{3} \\
\chi / Q^{\prime} \text { onsite } & \\
B R & =\text { breathing rate } \\
& =3.33 \mathrm{E}-04 \mathrm{~m}^{3} / \mathrm{s}
\end{aligned}
$$




$$
\begin{aligned}
U L D_{\text {onsite }} & =\text { onsite ULD (Table B-1) } \\
& =23 \mathrm{~Sv} / \mathrm{L} .
\end{aligned}
$$

The onsite dose for pneumatically transported waste is:

$$
\begin{aligned}
D_{\text {onsite }}=(136 \mathrm{~L})\left(3.28 \mathrm{E}-02 \mathrm{~s} / \mathrm{m}^{3}\right)\left(3.33 \mathrm{E}-04 \mathrm{~m}^{3} / \mathrm{s}\right)(23 \mathrm{~Sv} / \mathrm{L}) & =0.034 \mathrm{~Sv} \\
\times 100 \mathrm{rem} / \mathrm{Sv} & =3.4 \mathrm{rem}
\end{aligned}
$$

\section{B3.2.1.2 Onsite Toxicological Consequences}

The toxicological consequences are calculated per the methodology established in RPP-13482. The onsite toxicological consequences are determined by Equation B-2:

$$
\text { Onsite Consequence }=(Q / t)\left(\chi / Q_{\text {onsite }}^{\prime}\right)(S O F \text { Multiplier })
$$

where:

$$
\begin{aligned}
& \text { Consequence } \\
& \begin{aligned}
Q / t & \text { final sum of fractions value, unitless } \\
& =\text { rate of release to the environment, } 1.26 \mathrm{E}-03 \mathrm{~m}^{3} / \mathrm{s} \\
\chi^{\prime} Q^{\prime} & =\text { onsite atmospheric dispersion coefficient with plume depletion } \\
\text { SOF Multiplier } & =2.32 \mathrm{E}-03 \mathrm{~s} / \mathrm{m}^{3}
\end{aligned} \\
& \text { sum-of-fractions multiplier, unitless }
\end{aligned}
$$

The rate of release to the environment can be calculated based on the mass flow rate of pneumatically transported waste assuming a guillotine type break in the exhaust line from the vacuum pump using the transportability factor from above:

$$
\frac{4540 L}{h r} \times \frac{h r}{3600 s} \times \frac{m^{3}}{1000 L}=1.26 E-03 \frac{m^{3}}{s}
$$

The onsite moderate toxicological consequence, based on the TEEL-2 SOF multiplier listed in Table B-1, is:

$$
\begin{aligned}
& \text { Onsite Consequence }(\text { moderate })=\left(1.26 \mathrm{E}-03 \mathrm{~m}^{3} / \mathrm{s}\right)\left(2.32 \mathrm{E}-03 \mathrm{~s} / \mathrm{m}^{3}\right)(9.7 \mathrm{E}+07)=284 \\
& \text { where: }
\end{aligned}
$$$$
\text { 9.7 E+07= TEEL-2 SOF multiplier }
$$

The onsite high toxicological consequence, based on the TEEL-3 SOF multiplier listed in Table B-1, is:

$$
\text { Onsite Consequence }(\text { high })=\left(1.26 \mathrm{E}-03 \mathrm{~m}^{3} / \mathrm{s}\right)\left(2.32 \mathrm{E}-03 \mathrm{~s} / \mathrm{m}^{3}\right)(6.2 \mathrm{E}+06)=18.1
$$


where:

$$
6.2 \mathrm{E}+06=\text { TEEL-3 SOF multiplier. }
$$

\section{B3.2.1.3 Offsite Toxicological Consequences}

The offsite toxicological consequences are determined similarly:

$$
\text { Consequence }=\left(Q^{\prime} t\right)\left(\chi^{\prime} Q^{\prime}\right)(S O F \text { Multiplier })
$$

where:

$$
\begin{array}{ll}
\text { Consequence } & =\text { final sum of fractions value, unitless } \\
Q / t & =\text { rate of release to the environment, } 1.26 \mathrm{E}-03 \mathrm{~m}^{3} / \mathrm{s} \\
& =\text { offsite atmospheric dispersion coefficient with plume depletion } \\
\chi^{\prime} Q^{\prime} & =6.81 \mathrm{E}-07 \mathrm{~s} / \mathrm{m}^{3} \\
\text { SOF Multiplier } & =\text { sum-of-fractions multiplier, unitless. }
\end{array}
$$

The offsite moderate toxicological consequence, based on the TEEL-1 SOF multiplier listed in Table B-1, is:

Offsite Consequence $($ moderate $)=\left(1.26 \mathrm{E}-03 \mathrm{~m}^{3} / \mathrm{s}\right)\left(6.81 \mathrm{E}-07 \mathrm{~s} / \mathrm{m}^{3}\right)(6.5 \mathrm{E}+08)=0.56$

where:

$$
6.5 \mathrm{E}+08=\text { TEEL-1 SOF multiplier }
$$

\section{B3.2.2 SPILLS AND FALLS OF DRIED WASTE FROM BENEATH THE WASTE DRYER OUTLET (GREATER THAN 3 M)}

This case is based on a free-fall spill of the dried waste from the bottom of the waste dryer outlet, a height of approximately $11 \mathrm{ft}(3.4 \mathrm{~m})$. The consequences consist of two components: the aerosol generated by the spill and the subsequent entrainment from the resultant heap of waste, because not all of the material is made airborne.

The assumptions and input data relevant to this scenario are:

- The material at risk (MAR) is a full waste dryer batch of dried waste, or 4,540 L. It is assumed that a breach of the waste dryer outlet would empty the full contents of the waste dryer in $10 \mathrm{~min}$.

- An airborne release fraction (ARF) of $6.3 \mathrm{E}-03$ for the free-fall spill of cohesionless powders with a fall distance of greater than $3 \mathrm{~m}$ was selected from (Equation 4-5, pg. 4-81) DOE-HDBK-3010-94, Airborne Release Fractions/Rates and Respirable Fractions for Nonreactor Nuclear Facilities. Bounding ARF $=2(0.1064$ $\left.\left(\mathrm{M}_{\mathrm{o}}{ }^{0.125}\right)\left(\mathrm{H}^{2.37}\right) / \rho_{\mathrm{BP}}{ }^{1.02}\right)$ 


\section{RPP-20725 REV 2}

where:

$$
\begin{aligned}
& \mathrm{ARF}=\text { airborne release fraction } \\
& \mathrm{Mo}=\text { mass of powder spilled, } 7,040 \mathrm{~kg} \\
& \mathrm{H}=\text { spill height, } 3.4 \mathrm{~m} \\
& \rho_{\mathrm{BP}}=\text { bulk density of powder, } 1,550 \mathrm{~kg} / \mathrm{m}^{3} .
\end{aligned}
$$

- The airborne release rate (ARR) for aerodynamic entrainment and resuspension of a homogeneous bed of powder exposed to ambient conditions is $4 \mathrm{E}-05 \mathrm{hr}^{-1}$ (DOE-HDBK-3010-94, Sections 4.0 and 4.4.3).

- The respirable fraction (RF) (only used for radiological consequences) for the spill is conservatively assumed to be 1.0. DOE-HDBK-3010-94 does not indicate a RF value to be used with the ARF calculated above. Therefore, it is assumed that the RF for this case is 1.0 , because the comparison the handbook asks for is against an ARF $x$ RF combination.

- The RF (only used for radiological consequences) is 1.0 for aerodynamic entrainment and resuspension of a homogeneous bed of powder exposed to ambient conditions (DOE-HDBK-3010-94, Sections 4.0 and 4.4.3).

- The $\chi / \mathrm{Q}^{\prime}$ for the calculation of the radiological consequence of the release from the initial spill is the 1-hr $\chi / \mathrm{Q}^{\prime}$ given in Table B-2. The radiological consequence calculation of the resuspension and entrainment release uses the 8 -hr $\chi / \mathrm{Q}^{\prime}$.

- The 1-hr $\chi / \mathrm{Q}^{\prime} \mathrm{s}$ are also used for calculating the toxicological consequences of the resuspension and entrainment.

- For the toxicological consequences of the release during the spill from greater than $3 \mathrm{~m}$ high, a 1-hr $\chi / \mathrm{Q}^{\prime}$ is used (RPP-13482). The $\chi / \mathrm{Q}^{\prime} \mathrm{s}$ are shown in Table B-2.

\section{B3.2.2.1 Onsite Radiological Consequences}

The onsite dose for a free-fall spill of cohesionless powder from greater than $3 \mathrm{~m}$ high is found using the methodology in RPP-13482. The onsite dose from the impact of the spilled material on a surface is given by Equation B-1:

$$
D=(Q, \text { released })\left(\chi / Q^{\prime}\right)(B R)(U L D)
$$

where:

$$
\begin{aligned}
Q, \text { released } & =\text { liters of respirable material released to the environment }(\mathrm{L}) \\
& =M A R \times D R \times A R F \times R F \\
& =(4540 \mathrm{~L})(1)(6.3 \mathrm{E}-03)(1) \\
& =28.7 \mathrm{~L} \\
& =\text { onsite atmospheric dispersion coefficient }
\end{aligned}
$$




$$
\begin{aligned}
& =3.28 \mathrm{E}-02 \mathrm{~s} / \mathrm{m}^{3} \\
B R & =\text { breathing rate } \\
& =3.33 \mathrm{E}-04 \mathrm{~m}^{3} / \mathrm{s} \\
U L D \quad & =\text { onsite ULD, from Table B-1 } \\
& =23.0 \mathrm{~Sv} / \mathrm{L} .
\end{aligned}
$$

The onsite dose for the impact of the spilled material on a surface is:

$$
\begin{aligned}
D_{\text {spill }}=(28.7 \mathrm{~L})\left(3.28 \mathrm{E}-02 \mathrm{~s} / \mathrm{m}^{3}\right)\left(3.33 \mathrm{E}-04 \mathrm{~m}^{3} / \mathrm{s}\right)(23.0 \mathrm{~Sv} / \mathrm{L}) & =7.2 \mathrm{E}-03 \mathrm{~Sv} \\
& =7.2 \mathrm{E}-01 \mathrm{rem}
\end{aligned}
$$

The onsite dose for entrainment and resuspension can be found similarly using the ARR:

$$
D_{\text {entrainment }}=(Q, \text { released })\left(\chi / Q^{\prime}\right)(B R)(U L D)
$$

where:

$$
\begin{aligned}
Q, \text { released } & =\text { liters of respirable material released to the environment }(\mathrm{L}) \\
& =\text { MAR } \times \text { DR } \times A R R \times R F \times \text { release time } \\
& =(4,540 \mathrm{~L})(1)\left(4 \mathrm{E}-05 \mathrm{~h}^{-1}\right)(1.0)(8 \mathrm{~h}) \\
& =1.45 \mathrm{~L} \\
& =\text { onsite } 8-\mathrm{hr} \text { atmospheric dispersion coefficient } \\
& =5.58 \mathrm{E}-03 \mathrm{~s} / \mathrm{m}^{3} \\
& =\text { breathing rate } \\
B R \quad & =3.33 \mathrm{E}-04 \mathrm{~m}^{3} / \mathrm{s} \\
& =\text { onsite } \mathrm{ULD}, \text { from Table } \mathrm{B}-1 \\
& =23.0 \mathrm{~Sv} / \mathrm{L} .
\end{aligned}
$$

The onsite dose due to entrainment is:

$$
\begin{aligned}
D_{\text {entrainment }}=(1.45 \mathrm{~L})\left(5.58 \mathrm{E}-03 \mathrm{~s} / \mathrm{m}^{3}\right)\left(3.33 \mathrm{E}-04 \mathrm{~m}^{3} / \mathrm{s}\right)(23.0) & =6.2 \mathrm{E}-05 \mathrm{~Sv} \\
\times 100 \mathrm{rem} / \mathrm{Sv} & =6.2 \mathrm{E}-03 \mathrm{rem}
\end{aligned}
$$

The total onsite dose is the sum of the dose due to the free-fall spill and the entrainment from the unconfined powder:

$$
\begin{gathered}
\text { Dose }=D_{\text {spill }}+D_{\text {entrainment }} \\
\text { Dose }=7.2 \mathrm{E}-01 \mathrm{rem}+6.2 \mathrm{E}-03 \mathrm{rem}=7.3 \mathrm{E}-01 \mathrm{rem}
\end{gathered}
$$

Note: The entrainment contribution is a very smail contributor to the total radiological conseqeuences and a small fraction of the guideline. Therefore, entrainment calculations are ignored for the remaining radiological calculations. 


\section{RPP-20725 REV 2}

\section{B3.2.2.2 Onsite Toxicological Consequences}

The onsite toxicological consequences are determined by:

$$
\text { Consequence }_{\text {spill }}=\left(Q^{\prime} /\right)\left(\chi^{\prime} Q^{\prime}\right)(S O F \text { Multiplier })
$$

where:

$$
\begin{aligned}
\text { Consequence } & =\text { final sum of fractions value, unitless } \\
Q / t & =\text { rate of release to the environment }\left(\mathrm{m}^{3} / \mathrm{s}\right) \\
& =M A R / t \times D R \times A R F x \text { conversion factor } \\
& =(4,540 \mathrm{~L} / 600 \mathrm{~s})(1)(6.3 \mathrm{E}-03) / 1,000 \mathrm{~L} / \mathrm{m}^{3} \\
& =4.8 \mathrm{E}-05 \mathrm{~m}^{3} / \mathrm{s} \\
& =\text { onsite } 1-\mathrm{hr} \text { atmospheric dispersion coefficient } \\
& =3.28 \mathrm{E}-02 \mathrm{~s} / \mathrm{m}^{3}
\end{aligned}
$$

SOF Multiplier $=$ sum-of-fractions multiplier, unitless.

The onsite moderate toxicological consequence for a spill, based on the TEEL-2 SOF multiplier from Table B-1 is:

$$
\text { Consequence }_{\text {spill }}=\left(4.8 \mathrm{E}-05 \mathrm{~m}^{3} / \mathrm{s}\right)\left(3.28 \mathrm{E}-02 \mathrm{~s} / \mathrm{m}^{3}\right)(9.7 \mathrm{E}+07)=152
$$

where:

$$
\text { 9.7 } \mathrm{E}+07=\text { TEEL-2 SOF multiplier. }
$$

The onsite high toxicological consequence for a spill, based on the TEEL-3 SOF multiplier from Table B-1, is:

$$
\text { Consequence }_{\text {spill }}=\left(4.8 \mathrm{E}-05 \mathrm{~m}^{3} / \mathrm{s}\right)\left(3.28 \mathrm{E}-02 \mathrm{~s} / \mathrm{m}^{3}\right)(6.2 \mathrm{E}+06)=9.7
$$

where:

$$
6.2 \mathrm{E}+06=\text { TEEL-3 SOF multiplier. }
$$

The onsite consequence for entrainment and resuspension can be found similarly using the ARR:

$$
\text { Consequence }_{\text {entrainment }}=(Q / t)\left(\chi^{\prime} Q^{\prime}\right)(\text { SOF Multiplier })
$$


where:

$$
\begin{aligned}
& \text { Consequence } \\
& \begin{aligned}
Q / t & \text { final sum of fractions value, unitless } \\
& =\text { rate of release to the environment }\left(\mathrm{m}^{3} / \mathrm{s}\right) \\
& =M A R / t \times D R \times A R R \times \text { conversion factor } \\
& =(4,540 \mathrm{~L})(1)\left(4 \mathrm{E}-05 \mathrm{hr}^{-1}\right)(1)\left(1 / 1,000 \mathrm{~L} / \mathrm{m}^{3}\right) /(3,600 \mathrm{~s} / \mathrm{hr}) \\
& =5.04 \mathrm{E}-08 \mathrm{~m}^{3} / \mathrm{s} \\
& =\text { onsite atmospheric dispersion coefficient } \\
& =3.28 \mathrm{E}-02 \mathrm{~s}^{3} \mathrm{~m}^{3} \\
\chi / Q^{\prime} & \\
\text { SOF Multiplier } & =\text { sum-of-fractions multiplier, unitless. }
\end{aligned}
\end{aligned}
$$

The onsite moderate toxicological consequence for entrainment, based on the TEEL-2 SOF multiplier from Table B-1, is:

$$
\text { Consequence }_{\text {entrainment }}=\left(5.04 \mathrm{E}-08 \mathrm{~m}^{3} / \mathrm{s}\right)\left(3.28 \mathrm{E}-02 \mathrm{~s} / \mathrm{m}^{3}\right)(9.7 \mathrm{E}+07)=0.16
$$

where:

$$
\text { 9.7 E+07 = TEEL-2 SOF multiplier. }
$$

The onsite high toxicological consequence for entrainment (based on the TEEL-3 SOF multiplier) is:

$$
\text { Consequence }_{\text {entrainment }}=\left(5.04 \mathrm{E}-08 \mathrm{~m}^{3} / \mathrm{s}\right)\left(3.28 \mathrm{E}-02 \mathrm{~s} / \mathrm{m}^{3}\right)(6.2 \mathrm{E}+06)=0.01
$$

where:

$$
6.2 \mathrm{E}+06=\text { TEEL-3 SOF multiplier }
$$

The overall onsite toxicological consequences can be found by summing the contribution of the free-fall spill with the subsequent entrainment and resuspension.

The total onsite moderate toxicological consequence (based on TEEL-2) is:

$$
\text { Consequence }=152+0.16=152
$$

The total onsite high toxicological consequence (based on TEEL-3) is:

$$
\text { Consequence }=9.7+0.01=9.7
$$

Note: The entrainment contribution is a very small contributor to the total toxicological conseqeuences and a small fraction of the guideline. Entrainment calculations are ignored for the remaining toxicological calculations.

\section{B3.2.2.3 Offsite Toxicological Consequences}

The offsite toxicological consequences are determined similarly:

$$
\text { Consequence }=(Q / t)\left(\chi / Q^{\prime}\right)(S O F \text { Multiplier })
$$




\section{RPP-20725 REV 2}

where:

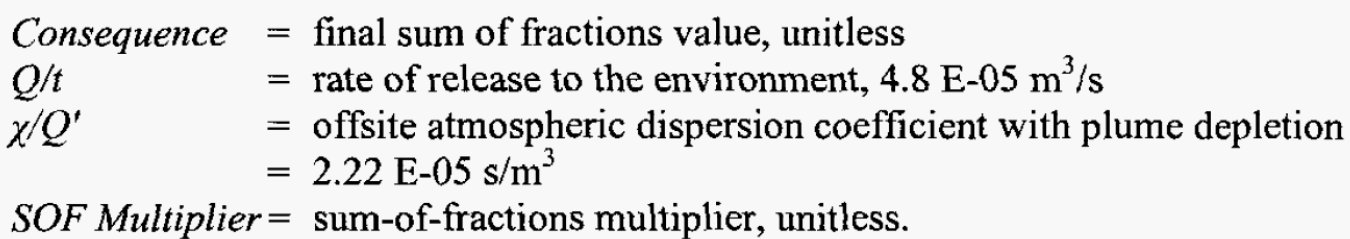

The offsite moderate toxicological consequence, based on the TEEL-1 SOF multiplier listed in Table B-1, is:

$$
\text { Offsite Consequence }(\text { moderate })=\left(4.8 \mathrm{E}-05 \mathrm{~m}^{3} / \mathrm{s}\right)\left(2.22 \mathrm{E}-05 \mathrm{~s} / \mathrm{m}^{3}\right)(6.5 \mathrm{E}+08)=0.69
$$

where:

$$
6.5 \mathrm{E}+08=\text { TEEL-1 SOF multiplier }
$$

\section{B3.2.3 SPILLS AND FALLS OF DRIED WASTE FROM AN IN-CONTAINER VITRIFICATION CONTAINER AFTER AN INTERRUPTED MELT (LESS THAN 3 M)}

This case is based on a free-fall spill of the dried waste from a partially filled ICV container that has to be moved from the melt area due to receipt of the non-compliant dryer batch. Conservatively, the melt is assumed to not have begun. The consequences consist of two components: the aerosol generated by the spill and the subsequent entrainment from the resultant heap of waste, because not all of the material is made airborne.

The assumptions and input data relevant to this scenario are:

- The MAR is three full waste dryer batches of dried waste, or 13,620 L. It is assumed that the release duration is $1 \mathrm{~min}$.

- The ARF is 2 E-03 for free-fall spill of cohesionless powders with a fall distance of less than $3 \mathrm{~m}$ (DOE-HDBK-3010-94, Sections 4.0 and 4.4.3).

- The entrainment contribution was shown to be a very small contributor to the total radiological and toxicological consequences and a small fraction of their respective guidelines. Therefore, entrainment calculations are ignored.

- The RF (used only for calculating radiological consequences) is 0.3 for a free-fall spill of a cohesionless powder with a fall distance of less than $3 \mathrm{~m}$ (DOE-HDBK-3010-94).

- The $\chi / \mathrm{Q}^{\prime}$ for the calculation of the radiological consequence of the release from the initial spill is the 1-hr $\chi / Q^{\prime}$ given in Table B-2. The radiological consequence calculation of the resuspension and entrainment release also uses the $1-\mathrm{hr} \chi / \mathrm{Q}^{\prime}$ 


\section{RPP-20725 REV 2}

- Due to the large size and mass of the ICV container, only a small fraction of its contents are expected to be ejected from the container in the release resulting from a spill, drop, or tipping accident. A damage ratio of 0.1 was assumed to account for the small fraction of dried waste involved in the release.

\section{B3.2.3.1 Onsite Radiological Consequences}

The onsite dose for a free-fall spill of cohesionless powder from less than $3 \mathrm{~m}$ high is found using the methodology in RPP-13482. The onsite dose from the impact of the spilled material on a surface is given by Equation B-1:

$$
D=(Q, \text { released })\left(\chi / Q^{\prime}\right)(B R)(U L D)
$$

where:

$$
\begin{aligned}
Q, \text { released } & =\text { liters of respirable material released to the environment }(\mathrm{L}) \\
& =M A R \times D R \times A R F \times R F \\
& =(13,620 \mathrm{~L})(0.1)(2 \mathrm{E}-03)(0.3) \\
& =0.82 \mathrm{~L} \\
& =\text { onsite atmospheric dispersion coefficient } \\
& =3.28 \mathrm{E}-02 \mathrm{~s}^{3} \\
& =\text { breathing rate } \\
& =3.33 \mathrm{E}-04 \mathrm{~m}^{3} / \mathrm{s} \\
B R \quad & =\text { onsite } \mathrm{ULD}, \text { from Table B-1 } \\
U L D \quad & 23.0 \mathrm{~Sv} / \mathrm{L} .
\end{aligned}
$$

The onsite dose for the impact of the spilled material on a surface is:

$$
\begin{aligned}
D_{\text {spill }}=(0.82 \mathrm{~L})\left(3.28 \mathrm{E}-02 \mathrm{~s} / \mathrm{m}^{3}\right)\left(3.33 \mathrm{E}-04 \mathrm{~m}^{3} / \mathrm{s}\right)(23.0 \mathrm{~Sv} / \mathrm{L}) & =2.1 \mathrm{E}-04 \mathrm{~Sv} \\
& =2.1 \mathrm{E}-02 \mathrm{rem}
\end{aligned}
$$

\section{B3.2.3.2 Onsite Toxicological Consequences}

The onsite toxicological consequences are determined by:

$$
\text { Consequence }_{\text {spill }}=\left(Q^{\prime} /\right)\left(\chi / Q^{\prime}\right)(S O F \text { Multiplier })
$$

where:

$$
\begin{aligned}
\text { Consequence } & =\text { final sum of fractions value, unitless } \\
Q / t & =\text { rate of release to the environment }\left(\mathrm{m}^{3} / \mathrm{s}\right) \\
& =M A R / t \times D R \times A R F x \text { conversion factor } \\
& =(13,620 \mathrm{~L} / 1 \mathrm{~min})(0.1)(2.0 \mathrm{E}-03) /\left[\left(1,000 \mathrm{~L} / \mathrm{m}^{3}\right)(60 \mathrm{~s} / \mathrm{min})\right] \\
& =4.5 \mathrm{E}-05 \mathrm{~m}^{3} / \mathrm{s} \\
& =\text { onsite atmospheric dispersion coefficient } \\
& =3.28 \mathrm{E}-02 \mathrm{~s} / \mathrm{m}^{3}
\end{aligned}
$$




\section{RPP-20725 REV 2}

SOF Multiplier $=$ sum-of-fractions multiplier, unitless.

The onsite moderate toxicological consequence for a spill, based on the TEEL-2 SOF multiplier calculated in Section B6.1 is:

$$
\text { Consequence }_{\text {spill }}=\left(4.5 \mathrm{E}-05 \mathrm{~m}^{3} / \mathrm{s}\right)\left(3.28 \mathrm{E}-02 \mathrm{~s} / \mathrm{m}^{3}\right)(9.7 \mathrm{E}+07)=144
$$

where:

$$
\text { 9.7 E+07 = TEEL-2 SOF multiplier. }
$$

The onsite high toxicological consequence for a spill, based on the TEEL-3 SOF multiplier from Table B-1, is:

$$
\text { Consequence }_{\text {spill }}=\left(4.5 \mathrm{E}-05 \mathrm{~m}^{3} / \mathrm{s}\right)\left(3.28 \mathrm{E}-02 \mathrm{~s} / \mathrm{m}^{3}\right)(6.2 \mathrm{E}+06)=9.2
$$

where:

$$
6.2 \mathrm{E}+06=\text { TEEL-3 SOF multiplier. }
$$

\section{B3.2.3.3 Offsite Toxicological Consequences}

The offsite toxicological consequences are determined similarly:

$$
\text { Consequence }=\left(Q^{\prime} t\right)\left(\chi / Q^{\prime}\right)(\text { SOF Multiplier })
$$

where:

$$
\begin{aligned}
& \text { Consequence }=\text { final sum of fractions value, unitless } \\
& Q / t \quad=\text { rate of release to the environment }\left(\mathrm{m}^{3} / \mathrm{s}\right) \\
& =M A R / t \times D R \times A R F \times R F \\
& =(13,620 \mathrm{~L} / 1 \mathrm{~min})(0.1)(2.0 \mathrm{E}-03)(1) /\left[\left(1,000 \mathrm{~L} / \mathrm{m}^{3}\right)(60 \mathrm{~s} / \mathrm{min})\right] \\
& =4.5 \mathrm{E}-05 \mathrm{~m}^{3} / \mathrm{s} \\
& \chi / Q^{\prime} \quad=\text { offsite atmospheric dispersion coefficient } \\
& =2.22 \mathrm{E}-05 \mathrm{~s} / \mathrm{m}^{3} \\
& \text { SOF Multiplier = sum-of-fractions multiplier, unitless. }
\end{aligned}
$$

The offsite moderate toxicological consequence for a spill (based on the TEEL-1 SOF multiplier) is:

$$
\text { Consequence }_{\text {spill }}=\left(4.5 \mathrm{E}-05 \mathrm{~m}^{3} / \mathrm{s}\right)\left(2.22 \mathrm{E}-05 \mathrm{~s} / \mathrm{m}^{3}\right)(6.5 \mathrm{E}+08)=6.5 \mathrm{E}-01
$$

where:

$$
\text { 6.5 E+08 = TEEL-1 SOF multiplier. }
$$




\section{B3.2.4 FILTRATION FAILURES}

Filtration failure scenario is considered:

- High-efficiency particulate air (HEPA) filter failure due to high temperature

- $\quad$ HEPA filter failure due to high pressure

- Unfiltered release from leakage around HEPA filters due to maintenance failure, misaligned filter, or damage to ductwork.

The following assumptions and input data apply to the filter failure scenarios:

- The maximum loading on each HEPA filter is assumed to be $1 \mathrm{~L}$ of solids based on filter plugging (i.e. high $\triangle \mathrm{P}$ and low flow rate). The load on each of the two prefilters is assumed to be $10 \%$ of the load on a HEPA filter and one HEPA load of waste is assumed to be plated out or trapped within the ductwork, heater, etc. upstream of the filters. The total load of waste within the particulate filter system (two prefilters, four HEPA filters, and one duct) subject to release is therefore assumed to be $5.2 \mathrm{HEPA}$ loads or $5.2 \mathrm{~L}$ of dried solids.

- The maximum ${ }^{129} \mathrm{I}$ loading on the activated carbon filter is assumed to be the total release from the processing of 100 waste containers with no credit for the off-gas scrubbers.

- Both first and second stage HEPA filters, prefilters, and the activated carbon filter are assumed to have a high waste loading and are assumed to be involved in a filter failure accident.

- The assumed maximum filter loadings take no credit for the OGTS. During normal design operation of the DBVS the loadings on all the exhaust filters would be negligible over the life of the facility.

- The activated carbon filter is assumed to burn up in the high temperature accident, releasing $100 \%$ of its ${ }^{129} \mathrm{I}$ loading. In the high pressure accident, the effect of the ${ }^{129} \mathrm{I}$ on the carbon filter is negligible compared to the other components of the release.

- The throughput of material into the OGTS is assumed to be equal to the dust generation rate during the ICV container filling operation.

- For purposes of estimating toxicological release rates, the filter releases from the over pressure event are assumed to be complete in less than $1 \mathrm{~min}$.

- For purposes of estimating toxicological release rates, the filter releases from the over temperature event are assumed to occur over a period of $15 \mathrm{~min}$.

- Release fractions from HEPA filters failed by over pressure or high temperature events are 2 E-06 and 1 E-04, respectively as recommended in DOE-HDBK-3010-94. 


\section{B3.2.4.1 EIGHT-HOUR UNFILTERED RELEASE}

The dust effluent from the container loading operation is assumed to be characterized by stream 20 (dust recycle) (RPP-20528, Appendix H). The dust generated by the process is assumed to be equal to the recycle rate given as $7.04 \mathrm{lb} / \mathrm{hr}$ [from RPP-20528, Appendix H (stream 20), $169 \mathrm{lb} /$ day $/ 24 \mathrm{hr} /$ day $=7.04 \mathrm{lb} / \mathrm{hr}](3.19 \mathrm{~kg} / \mathrm{hr}$ ) of dried waste with a bulk density of $1.55 \mathrm{~kg} / \mathrm{L}$. On a volumetric basis the dust flow rate is then $1.80 \mathrm{~L} / \mathrm{hr}$ or $5.0 \mathrm{E}-07 \mathrm{~m}^{3} / \mathrm{s}$. The 8-hr release would then be $14.4 \mathrm{~L}$.

\section{B3.2.4.1.1 Onsite Radiological Consequences}

The resulting radiological dose due to the 8 -hr continuous releases from the vitrification container fill operation with no filtration is shown below. Note that these doses assume a continuous, nonstop fill operation. In reality, the fill operation would alternate with vitrification of batches of material in the container.

The onsite dose is found using the methodology in RPP-13482. The dose is given by Equation B-1:

$$
D_{\text {onsite }}=(Q, \text { released })\left(\chi / Q_{\text {onsite }}^{\prime}\right)(B R)\left(U L D_{\text {onsite }}\right)
$$

where:

$$
\begin{aligned}
Q, \text { released } & =\text { liters of respirable material released to the environment }(\mathrm{L}) \\
& =14.4 \mathrm{~L} \\
\chi / Q_{\text {onsite }}^{\prime} & =\text { onsite eight hour atmospheric dispersion coefficient } \\
& =5.58 \mathrm{E}-03 \mathrm{~s} / \mathrm{m}^{3} \\
& =\text { breathing rate } \\
& =3.33 \mathrm{E}-04 \mathrm{~m}^{3} / \mathrm{s} \\
U L D_{\text {onsite }} & =\text { onsite ULD }(\text { Table B-1) } \\
& =23.0 \mathrm{~Sv} / \mathrm{L} .
\end{aligned}
$$

The dose is calculated as follows:

14.4 L $\times 5.58 \mathrm{E}-03 \mathrm{~s} / \mathrm{m}^{3} \times 3.33 \mathrm{E}-04 \mathrm{~m}^{3} / \mathrm{s} \times 23.0 \mathrm{~Sv} / \mathrm{L} \times 100 \mathrm{rem} / \mathrm{Sv}=6.2 \mathrm{E}-02 \mathrm{rem}$

Table B-4. Radiological Doses Due to 8-Hr Continuous Unfiltered Release.

\begin{tabular}{|c|c|c|c|}
\hline \multirow{3}{*}{ Receptor } & \multicolumn{3}{|c|}{ 8-Hr Release } \\
\cline { 2 - 4 } & Release & \multicolumn{2}{c|}{ Dose } \\
\cline { 2 - 4 } & $(\mathbf{L})$ & (Sv) & (rem) \\
\hline Onsite & 14.4 & $6.2 \mathrm{E}-04$ & $6.2 \mathrm{E}-02$ \\
\hline
\end{tabular}




\section{RPP-20725 REV 2}

\section{B3.2.4.1.2 Toxicological Consequences}

The toxicological consequences are calculated per the methodology established in RPP-13482. The onsite toxicological consequences are determined by Equation B-2:

Onsite Consequence $=\left(Q^{\prime} t\right)\left(\chi / Q^{\prime}{ }_{\text {onsite }}\right)(S O F$ Multiplier $)$

where:

$$
\begin{array}{ll}
\text { Consequence } & =\text { final sum of fractions value, unitless } \\
Q / t & =\text { rate of release to the environment, } 5.0 \mathrm{E}-07 \mathrm{~m}^{3} / \mathrm{s} \\
\chi / Q^{\prime} & =\text { onsite } 1-\mathrm{hr} \text { atmospheric dispersion coefficient } \\
& =3.28 \mathrm{E}-02 \mathrm{~s} / \mathrm{m}^{3} \\
\text { SOF Multiplier } & =\text { sum-of-fractions multiplier, unitless. }
\end{array}
$$

The onsite moderate toxicological consequence, based on the TEEL-2 SOF multiplier from Table B-1, is:

$$
\text { Onsite Consequence }(\text { moderate })=\left(5.0 \mathrm{E}-07 \mathrm{~m}^{3} / \mathrm{s}\right)\left(3.28 \mathrm{E}-02 \mathrm{~s} / \mathrm{m}^{3}\right)(9.7 \mathrm{E}+07)=1.6
$$

where:

$$
\text { 9.7 E+07 = TEEL-2 SOF multiplier }
$$

The onsite high toxicological consequence, based on the TEEL-3 SOF multiplier from Table B-1, is:

$$
\text { Onsite Consequence }(\text { high })=\left(5.0 \mathrm{E}-07 \mathrm{~m}^{3} / \mathrm{s}\right)\left(3.28 \mathrm{E}-02 \mathrm{~s} / \mathrm{m}^{3}\right)(6.2 \mathrm{E}+06)=0.10
$$

where:

$$
6.2 \mathrm{E}+06=\text { TEEL-3 SOF multiplier }
$$

The offsite toxicological consequences are determined similarly:

$$
\text { Consequence }=(Q / t)\left(\chi / Q^{\prime}\right)(\text { SOF Multiplier })
$$

where:

$$
\begin{array}{ll}
\text { Consequence } & =\text { final sum of fractions value, unitless } \\
Q^{\prime / t} & =\text { rate of release to the environment, } 5.0 \mathrm{E}-07 \mathrm{~m}^{3} / \mathrm{s} \\
\chi^{\prime} Q^{\prime} & =\text { offsite } 1-\mathrm{hr} \text { atmospheric dispersion coefficient } \\
& =2.22 \mathrm{E}-05 \mathrm{~s} / \mathrm{m}^{3} \\
\text { SOF Multiplier } & =\text { sum-of-fractions multiplier, unitless. }
\end{array}
$$




\section{RPP-20725 REV 2}

The offsite moderate toxicological consequence, based on the TEEL-1 SOF multiplier from Table B-1, is:

Offsite Consequence $($ moderate $)=\left(5.0 \mathrm{E}-07 \mathrm{~m}^{3} / \mathrm{s}\right)\left(2.22 \mathrm{E}-05 \mathrm{~s} / \mathrm{m}^{3}\right)(6.5 \mathrm{E}+08)=7.2 \mathrm{E}-03$

where:

$$
6.5 \mathrm{E}+08=\text { TEEL-1 SOF multiplier }
$$

The resulting SOFs for the continuous unfiltered release are shown in Table B-5.

Table B-5. Toxicological Sum of Fractions Relative to the Consequence Class Thresholds for a Continuous Unfiltered Release.

\begin{tabular}{|c|c|c|}
\hline Receptor & Release Rate (L/s) & Sum of Fractions \\
\hline \multirow{2}{*}{ Onsite } & \multirow{3}{*}{$5.0 \mathrm{E}-04$} & 1.6 (moderate) \\
\hline \multirow{2}{*}{ Offsite } & & 0.10 (high) \\
\cline { 3 - 3 } & & $7.2 \mathrm{E}-03$ (moderate) \\
\hline
\end{tabular}

\section{B3.2.4.2 HEPA FILTER FAILURE DUE TO HIGH TEMPERATURE}

The HEPA filter release fraction for the high temperature filter failure scenario is assumed to be $1 \mathrm{E}-04$ based on recommendations in Section 5.4.1 of DOE-HDBK-3010-94. This release fraction is assumed to also apply to the prefilter and the material in the upstream OGTS.

\section{B3.2.4.2.1 Onsite Radiological Consequences}

In the high temperature release scenario, the activated carbon filter is assumed to release $100 \%$ of its loading of ${ }^{129} \mathrm{I}$. The dose conversion factor (DCF) for ${ }^{129} \mathrm{I}$ is $5.1 \mathrm{E}-08 \mathrm{~Sv} / \mathrm{Bq}$ or $1.89 \mathrm{E}+05 \mathrm{rem} / \mathrm{Ci}$ for the onsite (collocated worker) receptor (from ICRP-68, Dose Coefficients for Intakes of Radionuclides by Workers - Replacement of ICRP Publication 61).

The onsite dose for the release from the filter due to high temperature is found using the methodology in RPP-13482 and is given by Equation B-1:

$$
D=(Q, \text { released })\left(\chi^{\prime} Q^{\prime}\right)(B R)(U L D)
$$

where:

$$
\begin{aligned}
Q, \text { released } & =\text { liters of respirable material released to the environment }(\mathrm{L}) \\
& =M A R \times D R \times A R F \times R F \\
& =(5.2 \mathrm{~L})(1)(1 \mathrm{E}-04)(1) \\
& =5.2 \mathrm{E}-04 \mathrm{~L} \\
& =\text { onsite } 1-\mathrm{hr} \text { atmospheric dispersion coefficient } \\
& =3.28 \mathrm{E}-02 \mathrm{~s} / \mathrm{m}^{3}
\end{aligned}
$$




\section{RPP-20725 REV 2}

$$
\begin{aligned}
B R & =\text { breathing rate } \\
& =3.33 \mathrm{E}-04 \mathrm{~m}^{3} / \mathrm{s} \\
U L D & =\text { onsite } \mathrm{ULD}, \text { from Table B-1 } \\
& =23.0 \mathrm{~Sv} / \mathrm{L} .
\end{aligned}
$$

\subsection{E-04 L x $3.28 \mathrm{E}-02 \mathrm{~s} / \mathrm{m}^{3} \times 3.33 \mathrm{E}-04 \mathrm{~m}^{3} / \mathrm{s} \times 23.0 \mathrm{~Sv} / \mathrm{L} \times 100 \mathrm{rem} / \mathrm{Sv}=1.3 \mathrm{E}-05 \mathrm{rem}$}

The contribution to the dose from the ${ }^{129} \mathrm{I}$ is calculated by multiplying the ${ }^{129} \mathrm{I}$ loading for 100 ICV containers (twice the expected mission), 2.15 E-01 Ci (RPP-20528, Appendix H, Stream 21) [2.15 E-03 Ci/ICV x $100 \mathrm{ICVs}$ ] by the dose conversion factor, $1.89 \mathrm{E}+05 \mathrm{rem} / \mathrm{Ci}$. The dose from ${ }^{129} \mathrm{I}$ is

2.15 E-01 Ci x $1.89 \mathrm{E}+05 \mathrm{rem} / \mathrm{Ci} \times 3.28 \mathrm{E}-02 \mathrm{~s} / \mathrm{m}^{3} \times 3.33 \mathrm{E}-04 \mathrm{~m}^{3} / \mathrm{s}=4.4 \mathrm{E}-01 \mathrm{rem}$

The total onsite radiological consequence is

$$
\text { Consequence }=1.3 \mathrm{E}-05 \mathrm{rem}+4.4 \mathrm{E}-01=4.4 \mathrm{E}-01 \mathrm{rem}
$$

\begin{tabular}{|c|c|c|c|c|c|c|}
\hline \multirow{3}{*}{ Receptor } & \multicolumn{3}{|c|}{ Initial Releases from Particulate Filters } & \multicolumn{3}{|c|}{${ }^{129}$ I Release from Carbon Filter } \\
\hline & \multirow{2}{*}{$\begin{array}{c}\text { Release } \\
\text { (L) }\end{array}$} & \multicolumn{2}{|c|}{ Dose } & \multirow{2}{*}{$\begin{array}{c}\text { Release } \\
\text { (Ci) }\end{array}$} & \multicolumn{2}{|c|}{ Dose } \\
\hline & & (Sv) & (rem) & & (Sv) & (rem) \\
\hline Onsite & $5.2 \mathrm{E}-04$ & $1.3 \mathrm{E}-07$ & $1.3 \mathrm{E}-05$ & $2.15 \mathrm{E}-01$ & $4.4 \mathrm{E}-03$ & $4.4 \mathrm{E}-01$ \\
\hline
\end{tabular}

The onsite radiological dose due to high temperature filter failure are shown in Table B-6 for both the dried waste releases from the particulate filters and the ${ }^{129} \mathrm{I}$ release from the carbon filter.

Table B-6. Radiological Doses from Filter Releases Due to High Temperature.

The scenario includes $8 \mathrm{hr}$ unfiltered release through the failed filters. Table B-4 shows the radiological doses due to the $8 \mathrm{hr}$ continuous release from the vitrification container fill operation with no filtration. Note that these doses assume a continuous, nonstop fill operation. In reality, the fill operation would alternate with vitrification of batches of material in the container.

The combined cases are shown in Table B-7. Total doses (particulates $+{ }^{129} \mathrm{I}$ ) are shown for the initial filter failure and then for the combined case that includes the $8 \mathrm{hr}$ of unfiltered release (14.4 L of dried waste) from the system through the failed filters. 


\section{RPP-20725 REV 2}

Table B-7. Total Radiological Doses from to Filtration Failure Due to High Temperature.

\begin{tabular}{|c|c|c|c|c|c|c|}
\hline \multirow{3}{*}{ Receptor } & \multicolumn{3}{|c|}{ Initial Release from Filters } & \multicolumn{3}{|c|}{ With 8-hr Unfiltered Release } \\
\hline & \multirow{2}{*}{ Release } & \multicolumn{2}{|c|}{ Dose } & \multirow{2}{*}{ Release } & \multicolumn{2}{|c|}{ Dose } \\
\hline & & (Sv) & (rem) & & (Sv) & (rem) \\
\hline Onsite & $\begin{array}{l}\text { Particulates } \\
\text { plus }{ }^{129} \mathrm{I}\end{array}$ & $4.4 \mathrm{E}-03$ & $4.4 \mathrm{E}-01$ & $\begin{array}{c}\text { Filters + } \\
14.4 \mathrm{~L}\end{array}$ & $5.0 \mathrm{E}-03$ & $5.0 \mathrm{E}-01$ \\
\hline
\end{tabular}

\section{B3.2.4.2.2 Toxicological Consequences}

In the case of toxicological exposures, the maximum concentration at the receptor is the operative parameter so that the 1-hr $\chi / \mathrm{Q}^{\prime}$, as shown in Table B-2 is used. The release rate $\mathrm{Q}^{\prime}$ is given in terms of liters of dried waste released per second averaged over a 15 -min release time. In evaluating Equation B-2, the release rate must be divided by $1,000 \mathrm{~L} / \mathrm{m}^{3}$ to make the units compatible with the $\chi / \mathrm{Q}^{\prime}$. The resulting SOFs for the continuous unfiltered release are shown in Table B-5.

Consistent with previous filtration failure analyses for tank farms facilities, it is assumed that the release from the filter in the high temperature failure scenario requires at least $15 \mathrm{~min}$ so the release is averaged over $900 \mathrm{~s}(15 \mathrm{~min})$. The resulting release rate and SOFs for the filter release are shown in Table B-8. The combined case with both the filter release and the unfiltered release from the off-gas system is also shown. It is assumed that both releases occur concurrently and are thus additive.

The onsite toxicological consequences are determined by Equation B-2:

$$
\text { Onsite Consequence }=(Q / t)\left(\chi / Q_{\text {onsite }}^{\prime}\right)(\text { SOF Multiplier })
$$

where:

$$
\begin{aligned}
\text { Consequence } & =\text { final sum of fractions value, unitless } \\
Q / t & =\text { rate of release to the environment } \\
& =(5.2 \mathrm{~L})(1 \mathrm{E}-04) /(900 \mathrm{~s})\left(1,000 \mathrm{~L} / \mathrm{m}^{3}\right)=5.8 \mathrm{E}-10 \mathrm{~m}^{3} / \mathrm{s} \\
& =\text { onsite } 1-\mathrm{hr} \text { atmospheric dispersion coefficient } \\
& =3.28 \mathrm{E}-02 \mathrm{~s} / \mathrm{m}^{3}
\end{aligned}
$$

SOF Multiplier $=$ sum-of-fractions multiplier, unitless.

The onsite moderate toxicological consequence, based on the TEEL-2 SOF multiplier from Table B-1, is:

$$
\text { Onsite Consequence }(\text { moderate })=\left(5.8 \mathrm{E}-10 \mathrm{~m}^{3} / \mathrm{s}\right)\left(3.28 \mathrm{E}-02 \mathrm{~s} / \mathrm{m}^{3}\right)(9.7 \mathrm{E}+07)=1.9 \mathrm{E}-03
$$

where:

$$
\text { 9.7 E+07= TEEL-2 SOF multiplier }
$$


The offsite toxicological consequences are determined similarly:

$$
\text { Consequence }=(Q / t)\left(\chi / Q^{\prime}\right)(\text { SOF Multiplier })
$$

where:

$$
\begin{array}{ll}
\text { Consequence } & =\text { final sum of fractions value, unitless } \\
Q / t & =\text { rate of release to the environment, } 5.8 \mathrm{E}-10 \mathrm{~m}^{3} / \mathrm{s} \\
& =\text { offsite } 1-\mathrm{hr} \text { atmospheric dispersion coefficient } \\
\chi / Q^{\prime} & =2.22 \mathrm{E}-05 \mathrm{~s} / \mathrm{m}^{3} \\
\text { SOF Multiplier } & =\text { sum-of-fractions multiplier, unitless. }
\end{array}
$$

The offsite moderate toxicological consequence, based on the TEEL-1 SOF multiplier from Table B-1, is:

$$
\text { Offsite Consequence }(\text { moderate })=\left(5.8 \mathrm{E}-10 \mathrm{~m}^{3} / \mathrm{s}\right)\left(2.22 \mathrm{E}-05 \mathrm{~s} / \mathrm{m}^{3}\right)(6.5 \mathrm{E}+08)=8.4 \mathrm{E}-06
$$

where:

$$
6.5 \mathrm{E}+08=\text { TEEL-1 SOF multiplier }
$$

Table B-8. Toxicological Sum of Fractions Relative to the Threshold For Moderate Consequence Class for High Temperature Filter Failure Release Scenario.

\begin{tabular}{|c|c|c|c|c|}
\hline \multirow{2}{*}{ Receptor } & \multicolumn{2}{|c|}{ Release from Filter Only } & \multicolumn{2}{c|}{ With Unfiltered Release } \\
\cline { 2 - 3 } & Release Rate (L/s) & SOF & Release Rate (L/s) & SOF \\
\hline \multirow{2}{*}{ Onsite } & \multirow{3}{*}{$5.8 \mathrm{E}-07$} & $1.9 \mathrm{E}-03$ & $5.8 \mathrm{E}-07$ & 1.6 (moderate) \\
\cline { 5 - 5 } & & $1.2 \mathrm{E}-04$ & + & 0.10 (high) \\
\hline \multirow{2}{*}{ Offsite } & & $8.4 \mathrm{E}-06$ & $5.0 \mathrm{E}-04$ & 7.2 E-03 (moderate) \\
\hline
\end{tabular}

Note:

SOF $=$ sum of fractions.

\section{B3.2.4.3 HEPA FILTER FAILURE DUE TO HIGH PRESSURE}

The filter release fraction for the high pressure failure scenario is assumed to be 2 E- 06 based on recommendations in Section 5.4.2.1 of DOE-HDBK-3010-94. This release fraction is assumed to also apply to the prefilter and the material in the upstream filtration system.

\section{B3.2.4.3.1 Onsite Radiological Consequences}

The onsite dose for the release from the filter due to high pressure is found using the methodology in RPP-13482 and is given by Equation B-1: 


$$
D=(Q, \text { released })\left(\chi / Q^{\prime}\right)(B R)(U L D)
$$

where:

$$
\begin{aligned}
Q, \text { released } & =\text { liters of respirable material released to the environment }(\mathrm{L}) \\
& =M A R \times D R \times A R F \times R F \\
& =(5.2 \mathrm{~L})(1)(2 \mathrm{E}-06)(1) \\
& =1.0 \mathrm{E}-05 \mathrm{~L} \\
& =\text { onsite } 1-\mathrm{hr} \text { atmospheric dispersion coefficient } \\
& =3.28 \mathrm{E}-02 \mathrm{~s}^{3} \\
& =\text { breathing rate } \\
& =3.33 \mathrm{E}-04 \mathrm{~m}^{3} / \mathrm{s} \\
B R & =\text { onsite } \mathrm{ULD}, \text { from Table B-1 } \\
U L D \quad & 23.0 \mathrm{~Sv} / \mathrm{L} .
\end{aligned}
$$

\begin{tabular}{|c|c|c|c|c|c|c|}
\hline \multirow{3}{*}{ Receptor } & \multicolumn{3}{|c|}{ Initial Release from Filters Only } & \multicolumn{3}{|c|}{ With 8-hr Unfiltered Release } \\
\hline & \multirow{2}{*}{$\begin{array}{c}\text { Release } \\
\text { (L) }\end{array}$} & \multicolumn{2}{|c|}{ Dose } & \multirow{2}{*}{$\begin{array}{c}\text { Release } \\
\text { (L) }\end{array}$} & \multicolumn{2}{|c|}{ Dose } \\
\hline & & (Sv) & (rem) & & (Sv) & (rem) \\
\hline Onsite & $1.0 \mathrm{E}-05$ & $2.5 \mathrm{E}-09$ & $2.5 \mathrm{E}-07$ & $\begin{array}{c}1.0 \mathrm{E}-05 \\
+14.4\end{array}$ & $6.2 \mathrm{E}-04$ & $6.2 \mathrm{E}-02$ \\
\hline
\end{tabular}

$$
=1.0 \mathrm{E}-05 \mathrm{~L} \times 3.28 \mathrm{E}-02 \mathrm{~s} / \mathrm{m}^{3} \times 3.33 \mathrm{E}-04 \mathrm{~m}^{3} / \mathrm{s} \times 23.0 \mathrm{~Sv} / \mathrm{L} \times 100 \mathrm{rem} / \mathrm{Sv}=2.5 \mathrm{E}-07 \mathrm{rem}
$$

Radiological doses due to high pressure filter failure are shown in Table B-9. Doses are shown for the initial filter failure and for the combined case that includes the $8 \mathrm{hr}$ of unfiltered release from the system through the failed filter.

Table B-9. Radiological Doses Due to Filtration Failure Due to High Pressure.

\section{B3.2.4.3.2 Toxicological Consequences}

Consistent with previous filtration failure analyses for tank farms facilities, it is assumed that the release from the filter in the high pressure failure scenario requires less than $1 \mathrm{~min}$ so the release is averaged over $60 \mathrm{~s}(1 \mathrm{~min})$. The resulting release rate and SOFs for the filter release are shown in Table B-10. The combined case with both the filter release and the unfiltered release from the off-gas system is also shown. It is assumed that both releases occur concurrently and are thus additive.

The onsite toxicological consequences are determined by Equation B-2:

Onsite Consequence $=(Q / t)\left(\chi / Q^{\prime}{ }_{\text {onsite }}\right)(S O F$ Multiplier $)$ 


\section{RPP-20725 REV 2}

where:

$$
\begin{aligned}
\text { Consequence } & =\text { final sum of fractions value, unitless } \\
& =\text { rate of release to the environment } \\
& =(5.2 \mathrm{~L})(2 \mathrm{E}-06) /(60 \mathrm{~s})\left(1,000 \mathrm{~L} / \mathrm{m}^{3}\right)=1.7 \mathrm{E}-10 \mathrm{~m}^{3} / \mathrm{s} \\
& =\text { onsite } 1-\mathrm{hr} \text { atmospheric dispersion coefficient } \\
& =3.28 \mathrm{E}-02 \mathrm{~s} / \mathrm{m}^{3} \\
\text { SOF Multiplier } & =\text { sum-of-fractions multiplier, unitless. }
\end{aligned}
$$

The onsite moderate toxicological consequence, based on the TEEL-2 SOF multiplier from Table B-1, is:

$$
\text { Onsite Consequence }(\text { moderate })=\left(1.7 \mathrm{E}-10 \mathrm{~m}^{3} / \mathrm{s}\right)\left(3.28 \mathrm{E}-02 \mathrm{~s} / \mathrm{m}^{3}\right)(9.7 \mathrm{E}+07)=5.4 \mathrm{E}-04
$$

where:

$$
9.7 \mathrm{E}+07=\text { TEEL-2 SOF multiplier }
$$

The offsite toxicological consequences are determined similarly:

$$
\text { Consequence }=(Q / t)\left(\chi / Q^{\prime}\right)(S O F \text { Multiplier })
$$

where:

$$
\begin{array}{ll}
\text { Consequence } & =\text { final sum of fractions value, unitless } \\
Q^{\prime / t} & =\text { rate of release to the environment, } 1.7 \mathrm{E}-10 \mathrm{~m}^{3} / \mathrm{s} \\
\chi^{\prime} Q^{\prime} & =\text { offsite } 1-\mathrm{hr} \text { atmospheric dispersion coefficient } \\
& =2.22 \mathrm{E}-05 \mathrm{~s} / \mathrm{m}^{3} \\
\text { SOF Multiplier } & =\text { sum-of-fractions multiplier, unitless. }
\end{array}
$$

The offsite moderate toxicological consequence, based on the TEEL-1 SOF multiplier from Table B-1, is:

Offsite Consequence $($ moderate $)=\left(1.7 \mathrm{E}-10 \mathrm{~m}^{3} / \mathrm{s}\right)\left(2.22 \mathrm{E}-05 \mathrm{~s} / \mathrm{m}^{3}\right)(6.5 \mathrm{E}+08)=2.5 \mathrm{E}+06$ where:

$$
6.5 \mathrm{E}+08=\text { TEEL-1 SOF multiplier }
$$


Table B-10. Toxicological Sum of Fractions Relative to the Threshold for Moderate Consequence Class for High Pressure Filter Failure Release Scenario.

\begin{tabular}{|c|c|c|c|c|}
\hline \multirow{2}{*}{ Receptor } & \multicolumn{2}{|c|}{ Release from Filter Only } & \multicolumn{2}{|c|}{ With Unfiltered Release } \\
\hline & Release Rate $(\mathrm{L} / \mathrm{s})$ & SOF & Release Rate (L/s) & SOF \\
\hline \multirow{2}{*}{ Onsite } & \multirow{4}{*}{$1.7 \mathrm{E}-07$} & $5.4 \mathrm{E}-04$ & \multirow{4}{*}{$\begin{array}{c}1.7 \text { E-07 } \\
+ \\
5.2 \text { E-04 }\end{array}$} & 1.6 (moderate) \\
\hline & & $3.5 \mathrm{E}-05$ & & 0.010 (high) \\
\hline \multirow{2}{*}{ Offsite } & & $2.5 \mathrm{E}-06$ & & $7.2 \mathrm{E}-03$ (moderate) \\
\hline & & -- & & -- \\
\hline
\end{tabular}

Note:

SOF $=$ sum of fractions.

\section{B4.0 RESULTS}

Table B-11 compares the accident consequences with the onsite radiological risk evaluation guidelines. Reviewing the consequences shows that the release of dried radioactive waste representative accident is below the onsite radiological guideline for moderate consequences for the pneumatic case, spill from the top of the dried waste receiver, spill of less than $3 \mathrm{~m}$.

Table B-11. Summary of Onsite Radiological Consequences Without Controls for the Release of Dried Radioactive Waste During Demonstration Bulk Vitrification System Operations.

\begin{tabular}{|l|c|c|c|}
\hline \multirow{2}{*}{ Case } & \multicolumn{3}{|c|}{ Onsite radiological consequences } \\
\cline { 2 - 4 } & $\begin{array}{c}\text { Calculated dose } \\
\text { (rem) }\end{array}$ & $\begin{array}{c}\text { Moderate } \\
\text { consequence } \\
\text { guideline } \\
\text { (rem) }\end{array}$ & $\begin{array}{c}\text { High consequence } \\
\text { guideline } \\
\text { (rem) }\end{array}$ \\
\hline $\begin{array}{l}\text { Release of pneumatically } \\
\text { transported dried radioactive waste }\end{array}$ & 3.4 & 25 & 100 \\
\hline $\begin{array}{l}\text { Spills and falls of dried radioactive } \\
\text { waste from beneath the waste } \\
\text { dryer outlet }(\sim 11 \mathrm{ft} / 3.4 \mathrm{~m})\end{array}$ & 0.73 & 25 & 100 \\
\hline $\begin{array}{l}\text { Release of dried radioactive waste } \\
\text { from the ICV container after } \\
\text { relocation from melt area after } \\
\text { interrupted melt }\end{array}$ & $3.2 \mathrm{E}-02$ & 25 & 100 \\
\hline $\begin{array}{l}\text { Filtration failure leading to } \\
\text { unfiltered release (high } \\
\text { temperature) }\end{array}$ & $5.0 \mathrm{E}-01$ & 25 & 100 \\
\hline
\end{tabular}

Note:

ICV $=$ In-Container Vitrification. 
Table B-12 compares the accident consequences with the toxicological risk evaluation guidelines. Reviewing the consequences shows that the release of dried radioactive waste representative accident is above the onsite toxicological guideline for "high" consequences for the pneumatic, dryer outlet, and ICV release cases. For filtration failures, the onsite "moderate" consequence guideline is exceeded. For offsite consequences, the consequences are below the "moderate" consequence guideline for all cases.

Table B-12. Summary of Toxicological Consequences Without Controls for the Release of Dried Radioactive Waste Representative Accident.

\begin{tabular}{|c|c|c|c|c|c|c|c|c|}
\hline \multirow{4}{*}{ Case } & \multicolumn{8}{|c|}{ Toxicological consequences } \\
\hline & \multicolumn{4}{|c|}{ Onsite } & \multicolumn{4}{|c|}{ Offsite } \\
\hline & \multicolumn{2}{|c|}{$\begin{array}{c}\text { Moderate } \\
\text { consequence }\end{array}$} & \multicolumn{2}{|c|}{ High consequence } & \multicolumn{2}{|c|}{$\begin{array}{c}\text { Moderate } \\
\text { consequence }\end{array}$} & \multicolumn{2}{|c|}{ High consequence } \\
\hline & SOF & Guideline & SOF & Guideline & SOF & Guideline & SOF & Guideline \\
\hline $\begin{array}{l}\text { Release of } \\
\text { pneumatically } \\
\text { transported dried } \\
\text { radioactive waste }\end{array}$ & 284 & 1 & 18.1 & 1 & 0.56 & 1 & -- & 1 \\
\hline $\begin{array}{l}\text { Spills and falls of } \\
\text { dried radioactive waste } \\
\text { from beneath the waste } \\
\text { dryer outlet }(\sim 11 \mathrm{ft} / 3.4 \\
\mathrm{m})\end{array}$ & 152 & 1 & 9.7 & 1 & 0.69 & 1 & -- & 1 \\
\hline $\begin{array}{l}\text { Release of dried } \\
\text { radioactive waste from } \\
\text { ICV container after } \\
\text { interrupted melt }\end{array}$ & 144 & 1 & 9.2 & 1 & 0.65 & 1 & -- & 1 \\
\hline $\begin{array}{l}\text { Filtration failure } \\
\text { leading to unfiltered } \\
\text { release (High } \\
\text { Temperature) }\end{array}$ & 1.6 & 1 & 0.10 & 1 & $7.2 \mathrm{E}-03$ & 1 & -- & 1 \\
\hline
\end{tabular}

Note:

ICV $=$ In-Container Vitrification.

$\mathrm{SOF}=$ sum of fractions.

The results show that, even with no credit for the DBVS OGTS, the direct release of the dust generated by the vitrification container fill operation results in low consequence radiological doses for all scenarios. The toxicological consequences rise to the moderate level only for the onsite receptor. It is also evident that the consequences from the failure of the exhaust filters are negligible compared to the consequences due to direct dust release from the fill operation over an 8-hr period.

The control for mitigating the consequences of the filtration failure includes ensuring that the release occurs through the exhaust stack at $155 \mathrm{ft}$ high. The onsite $\chi / \mathrm{Q}^{\prime}$ for the elevated release is 4.77 E-05 s/m $\mathrm{m}^{3}$ (RPP-23572, Technical Basis Document for Release of Process Off-Gas with Toxic Components). When this dispersion coefficient is applied to the onsite toxicological 
RPP-20725 REV 2

consequences, the SOF becomes $2.3 \mathrm{E}-03$. Thus the consequences for all receptors for the mitigated accident are in the "low" consequence bin.

\section{B5.0 REFERENCES}

DOE-HDBK-3010-94, 2000, Airborne Release Fractions/Rates and Respirable Fractions for Nonreactor Nuclear Facilities, Change Notice No. 1, U.S. Department of Energy, Washington, D.C.

ICRP-68, 1994, Dose Coefficients for Intakes of Radionuclides by Workers - Replacement of ICRP Publication 61, ICRP Publication 68, Annals of the ICRP, Vol. 24, Number 4, Elsevier Science, Tarrytown, New York.

RPP-13482, 2006, Atmospheric Dispersion Coefficients and Radiological and Toxicological Exposure Methodology for Use in Tank Farms, Rev. 6, CH2M HILL Hanford Group, Inc., Richland, Washington.

RPP-20528, 2006, Demonstration Bulk Vitrification System Flowsheet, Rev. 1, CH2M HILL Hanford Group, Inc., Richland, Washington.

RPP-23572, 2007, Technical Basis Document for Release of Process Off-Gas with Toxic Components, Rev. 1, CH2M HILL Hanford Group, Inc., Richland, Washington.

RPP-CALC-30596, 2006, Demonstration Bulk Vitrification System Accident Analysis Source Terms, Rev. 0, CH2M HILL Hanford Group, Inc., Richland, Washington 
RPP-20725 REV 2

APPENDIX C

PEER REVIEW CHECKLISTS

FOR THE DEMONSTRATION BULK VITRIFICATION SYSTEM

C-i 


\section{RPP-20725 REV 2}

This page intentionally left blank. 


\title{
APPENDIX C \\ PEER REVIEW CHECKLISTS \\ FOR THE DEMONSTRATION BULK VITRIFICATION SYSTEM
}

\section{CHECKLIST FOR TECHNICAL PEER REVIEW}

\author{
Document Reviewed: RPP-20725, Release of Dried Radioactive Waste Materials Technical \\ Basis Document, Rev. 2
}

Scope of Review (e.g., document section or portion of calculation): Revision 2 changes only. Yes No NA*

[X ] [ [ ] 1. Previous reviews are complete and cover the analysis, up to the scope of this review, with no gaps.

[X] [ ] [ ] 2. Problem is completely defined.

[X] [ ] [ ] 3. Accident scenarios are developed in a clear and logical manner.

[X] [ ] [] 4. Analytical and technical approaches and results are reasonable and appropriate. (ORP QAPP criterion 2.8)

[X] [ ] [ ] 5. Necessary assumptions are reasonable, explicitly stated, and supported. (ORP QAPP criterion 2.2)

[ ] [] $[\mathrm{X}]$ 6. Computer codes and data files are documented.

[X] [] [ ] 7. Data used in calculations are explicitly stated.

[X] [] [ ] 8. Bases for calculations, including assumptions and data, are consistent with the supported safety basis document (e.g., the Tank Farms Final Safety Analysis Report).

[X] [] [ ] 9. Data were checked for consistency with original source information as applicable. (ORP QAPP criterion 2.9)

[X] [ ] [ ] 10. For both qualitative and quantitative data, uncertainties are recognized and discussed, as appropriate. (ORP QAPP criterion 2.17)

[X] [ ] [ ] 11. Mathematical derivations were checked including dimensional consistency of results. (ORP QAPP criterion 2.16)

[X] [ ] [ ] 12. Models are appropriate and were used within their established range of validity or adequate justification was provided for use outside their established range of validity.

[] [ ] [X] 13. Spreadsheet results and all hand calculations were verified.

[X] [ ] [ ] 14. Calculations are sufficiently detailed such that a technically qualified person can understand the analysis without requiring outside information. (ORP $Q A P P$ criterion 2.5)

[ ] [ ] [X] 15. Software input is correct and consistent with the document reviewed.

[] [] [X] 16. Software output is consistent with the input and with the results reported in the document reviewed.

[ ] [ ] [X] 17. Software verification and validation are addressed adequately. (ORP QAPP criterion 2.6)

[X] [ ] [ ] 18. Limits/criteria/guidelines applied to the analysis results are appropriate and referenced. Limits/criteria/guidelines were checked against references. (ORP QAPP criterion 2.9)

[X] [] [ ] 19. Safety margins are consistent with good engineering practices.

[X] [ ] [ ] 20. Conclusions are consistent with analytical results and applicable limits.

[X] [ ] [ ] 21. Results and conclusions address all points in the purpose. (ORP QAPP criterion 2.3)

[X] [ ] [ ] 22. All references cited in the text, figures, and tables are contained in the reference list.

[X] [ ] [ ] 23. Reference citations (e.g., title and number) are consistent between the text callout and the reference list.

[X] [ ] [ ] 24. Only released (i.e., not draft) references are cited. (ORP QAPP criterion 2.1) 


\section{RPP-20725 REV 2}

[X] [ ] [ ] 25. Referenced documents are retrievable or otherwise available.

[X] [ ] [ ] 26. The most recent version of each reference is cited, as appropriate. (ORP QAPP criterion 2.I)

[X] [ ] [ ] 27. There are no duplicate citations in the reference list.

[X] [ ] [] 28. Referenced documents are spelled out (title and number) the first time they are cited.

[X] [ ] [ ] 29. All acronyms are spelled out the first time they are used.

[X] [] [] 30. The Table of Contents is correct.

[X] [] [] 31. All figure, table, and section callouts are correct.

[X] [ ] [ ] 32. Unit conversions are correct and consistent.

[X] [] [ ] 33. The number of significant digits is appropriate and consistent.

[ ] [] [X] 34. Chemical reactions are correct and balanced.

[X] [ ] [ ] 35. All tables are formatted consistently and are free of blank cells.

[X] [] [] 36. The document is complete (pages, attachments, and appendices) and in the proper order.

[X] [] [ ] 37. The document is free of typographical errors.

[X] [] [] 38. The tables are internally consistent.

[X] [] [] 39. The document was prepared in accordance with HNF-2353, Section 4.3, Attachment B, "Calculation Note Format and Preparation Instructions".

[X] [] [ ] 40. Impacted documents are appropriately identified in Blocks 7 and 25 of the Engineering Change Notice (form A-6003-563.1).

[ ] [ ] [X] 41. If more than one Technical Peer Reviewer was designated for this document, an overall review of the entire document was performed after resolution of all Technical Peer Review comments and confirmed that the document is selfconsistent and complete.

\section{[X] [ ] [I Concurrence}

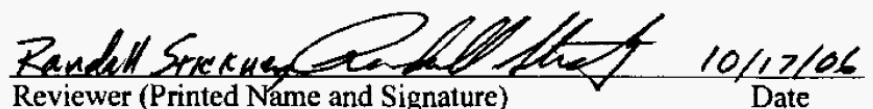

- If No or NA is chosen, provide an explanation on this form.

- Computer codes not used for this analysis.

- No chemical reactions are included in this analysis. 
RPP-20725 REV 2

\section{CHECKLIST FOR TECHNICAL PEER REVIEW}

Document Reviewed: RPP-20725, Release of Dried Radioactive Waste Materials Technical Basis Document, Rev. 2

Scope of Review (e.g., document section or portion of calculation): Technical edit

Yes No NA*

[ ] [ ] [x] 1. Previous reviews are complete and cover the analysis, up to the scope of this review, with no gaps.

[ ] [ ] [x] 2. Problem is completely defined.

[] [] [x] 3. Accident scenarios are developed in a clear and logical manner.

[] [] [x] 4. Analytical and technical approaches and results are reasonable and appropriate. (ORP QAPP criterion 2.8)

[ ] [ ] [x] 5. Necessary assumptions are reasonable, explicitly stated, and supported. (ORP QAPP criterion 2.2)

[] [ ] [x] 6. Computer codes and data files are documented.

[] [ ] [x] 7. Data used in calculations are explicitly stated.

[] [] [x] 8. Bases for calculations, including assumptions and data, are consistent with the supported safety basis document (e.g., the Tank Farms Documented Safety Analysis).

[ ] [ ] [ $\mathrm{x}$ ] 9. Data were checked for consistency with original source information as applicable. (ORP QAPP criterion 2.9)

[ ] [ ] [x] 10. For both qualitative and quantitative data, uncertainties are recognized and discussed, as appropriate. (ORP $Q A P P$ criterion 2.17)

[ ] [ ] [x] 11. Mathematical derivations were checked including dimensional consistency of results. (ORP QAPP criterion 2.16)

[] [] [x] 12. Models are appropriate and were used within their established range of validity or adequate justification was provided for use outside their established range of validity.

[ ] [ ] [x] 13. Spreadsheet results and all hand calculations were verified.

[ ] [] [x] 14. Calculations are sufficiently detailed such that a technically qualified person can understand the analysis without requiring outside information. (ORP QAPP criterion 2.5)

[ ] [ ] [x] 15. Software input is correct and consistent with the document reviewed.

[] [ ] [x] 16. Software output is consistent with the input and with the results reported in the document reviewed.

[ ] [ ] [x] 17. Software verification and validation are addressed adequately. (ORP QAPP criterion 2.6)

[] [ ] [x] 18. Limits/criteria/guidelines applied to the analysis results are appropriate and referenced. Limits/criteria/guidelines were checked against references. (ORP QAPP criterion 2.9)

[ ] [ ] [X] 19. Safety margins are consistent with good engineering practices.

[] [] [x] 20. Conclusions are consistent with analytical results and applicable limits.

$$
v_{10}^{m^{h}} k-\infty
$$




\section{CHECKLIST FOR TECHNICAL PEER REVIEW}

[ ] [ ] [x] 21. Results and conclusions address all points in the purpose. (ORP QAPP criterion 2.3)

[x] [ ] [ ] 22. All references cited in the text, figures, and tables are contained in the reference list.

[x] [ ] [ ] 23. Reference citations (e.g., title and number) are consistent between the text callout and the reference list.

[x] [] [ ] 24. Only released (i.e., not draft) references are cited. (ORP QAPP criterion 2.I)

[x] [ ] [] 25. Referenced documents are retrievable or otherwise available.

[x] [] [ ] 26. The most recent version of each reference is cited, as appropriate. (ORP QAPP criterion 2.I)

[x] [ ] [ ] 27. There are no duplicate citations in the reference list.

[x] [ ] [ ] 28. Referenced documents are spelled out (title and number) the first time they are cited.

[x] [ ] [ ] 29. All acronyms are spelled out the first time they are used.

[x] [] [ ] 30. The Table of Contents is correct.

[x] [] [ ] 31. All figure, table, and section callouts are correct.

[x] [ ] [ ] 32. Unit conversions are correct and consistent.

[x] [ ] [ ] 33. The number of significant digits is appropriate and consistent.

[ ] [ ] [x] 34. Chemical reactions are correct and balanced.

[x] [ ] [ ] 35. All tables are formatted consistently and are free of blank cells.

[x] [] [] 36. The document is complete (pages, attachments, and appendices) and in the proper order.

[x] [ ] [ ] 37. The document is free of typographical errors.

[x] [ ] [ ] 38. The tables are internally consistent.

[x] [ ] [ ] 39. The document was prepared in accordance with HNF-2353, Section 4.3, Attachment B, "Calculation Note Format and Preparation Instructions".

[ ] [] [x] 40. Impacted documents are appropriately identified in Blocks 7 and 25 of the Engineering Change Notice (form A-6003-563.1).

[x] [ ] [ ] 41. If more than one Technical Peer Reviewer was designated for this document, an overall review of the entire document was performed after resolution of all Technical Peer Review comments and confirmed that the document is selfconsistent and complete.

[x] [ [ ] [ []

Concurrence

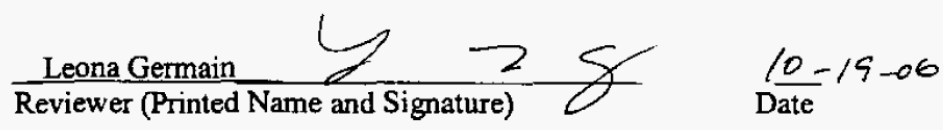

* If No or NA is chosen, provide an explanation on this form.

Technical Edit 


\section{NS\&L CHECKLIST FOR TECHNICAL PEER REVIEW}

Document Reviewed: RPP-20725, Release of Dried Radioactive Waste Materials Technical Basis Document

Scope of Review (e.g., document section or portion of calculation): Changes made to document on $10 / 10 / 06$ as a result of prior pecr reviews.

\footnotetext{
Yes No* NA

1. Previous reviews are complete and cover the analysis, up to the scope of this review, with no gaps. "Explanation:

2. Problem is completely defined. *Explanation:

3. Accident scenarios are developed in a clear and logical manner.

4. Analytical and technical approaches and results are reasonable and appropriate. (ORP QAPP criterion 2.8) *Explanation:

5. Necessary assumptions are reasonable, explicitly stated, and supported. (ORP $Q A P P$ criterion 2.2) *Explanation:

6. Computer codes and data files are documented. "Explanation:

7. Data used in calculations are explicitly stated.

Explanation:

8. Bases for calculations, including assumptions and data, are consistent with the supported safety basis document (e.g., the Tank Farms Documented Safety Analysis). *Explanation:

9. Data were checked for consistency with original source information as applicable. (ORP QAPP criterion 2.9) *Explanation:

10. For both qualitative and quantitative data, uncertainties are recognized and discussed, as appropriate. (ORP $Q A P P$ criterion 2.17)

$\bigotimes \square \square \quad \begin{gathered}\text { 11. Mathematical derivations were check } \\ \text { results. (ORP QAPP criterion 2.16) } \\ \text { *Explantion: }\end{gathered}$

$\bigotimes \square \square \quad$ 12. Models are appropriate and were used within their established range of validity or adequate justification was provided for use outside their established range of validity. "Explanation:

$\otimes \quad$ 13. Spreadsheet results and all hand calculations were verified. *Explanation:

14. Calculations are sufficiently detailed such that a technically qualified person can understand the analysis without requiring outside information. (ORP $Q A P P$ criterion 2.5) "Explanation:

$\otimes \quad$ 15. Software input is correct and consistent with the document reviewed.

16. Sotplanation:
16. Software output is consistent with the input and with the results reported in the document reviewed. "Explanation:

$\otimes \quad$ 17. Software verification and validation are addressed adequately. (ORP QAPP criterion 2.6) "Explanation:

18. Limits/criteria/guidelines applied to the analysis results are appropriate and referenced. Limits/criteria/guidelines were checked against references. (ORP QAPP criterion 2.9) *Explanatton:

$\triangle \square \square \quad$ 19. Safety margins are consistent with good engineering practices.

$\triangle \square \square \quad 20$. Conclusions are consistent with analytical results and applicable limits.

$\triangle 1$ "Explanation:

1. Resplanation:
2.3) *Exptanotion:

$\triangle 2.3$ * Explanotion:

$\bigotimes \quad$ 22. All references cited in the text, figures, and tables are contained in the reference list. "Explanation:
}

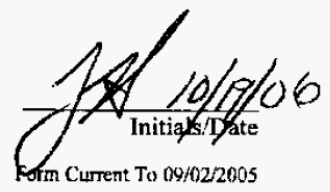




\section{NS\&L CHECKLIST FOR TECHNICAL PEER REVIEW}

Yes No* NA

$\frac{\mathrm{Yes}}{\mathrm{X}}$

$\square \square$

$\square \square$

$\square \square \otimes$

$\square \square \otimes$

$\square \square$ Q

$\square \square$ Q

$\square \square$

$\square \square \otimes$

$\square \square \otimes$

$\square \square \otimes$

$\square \square \otimes$

$\square \square \otimes$

$凶 \square \square$

$凶 \square \square$

$\otimes$

$\square \square \otimes$

$\otimes \square \square$

$\otimes \square \square \quad \begin{gathered}\text { consistent } \\ \text { Concurrence }\end{gathered}$

John P. Harris, III

Reviewer (Printed tame and Signature) and the reference list.

23. Reference citations (e.g., title and number) are consistent between the text callout

24. Only released (i.e., not draft) references are cited. (ORP QAPP criterion 2.1)

"Explanatlon:

25. Referenced documents are retrievable or otherwise available. Explanation:

26. The most recent version of each reference is cited, as appropriate. (ORP QAPP criterion 2.1) *Explamation:

27. There are no duplicate citations in the reference list.

"Explanation:

28. Referenced documents are spelled out (title and number) the first time they are cited. "Explanafion:

29. All acronyms are spelled out the first time they are used. *Explanation:

30. The Table of Contents is correct. *Explanation:

31. All figure, table, and section callouts are correct.

"Explanution:

2. Unit conversions are correct and consistent.

33. The number of significant digits is appropriate and consistent.

34. Chemical reactions are correct and balanced.

tanation:

35. All tables are formatted consistently and are free of blank cells.

"Explanation:

36. The document is complete (pages, attachments, and appendices) and in the proper der. "Explanation:

37. The document is free of typographical errors. Only the section(s) being reviewed was checked for typographical errors. "Explanation:

38. The tables are internally consistent. *Explanation:

39. The document was prepared in accordance with HNF-2353, Section 4.3, Attachment B, "Calculation Note Format and Preparation Instructions." Explanation:

40. Impacted documents are appropriately identified in Blocks 7 and 25 of the Engineering Change Notice (form A-6003-563.1).

41. If more than one Technical Peer Reviewer was designated for this document, an overall review of the entire document was performed after resolution of all Technical Peer Review comments and confipmed that the document is selfent and complete.*Explanation:

, an explantiop/must be provided on this form.

* If No is chosen, an explanqtiop must be provided on this form.

Additional explanation: Only changes made to the document from previous peer review was included within the scope of this review. 
RPP-20725 REV 2

APPENDIX D

CONTACT-HANDLED TRANSURANIC MIXED WASTE PACKAGING UNIT FACILITY ANALYSIS 


\section{RPP-20725 REV 2}

This page intentionally left blank.

D-ii 
RPP-20725 REV 2

\section{APPENDIX D}

\section{CONTACT-HANDLED TRANSURANIC MIXED WASTE PACKAGING UNIT FACILITY ANALYSIS}

\section{D1.0 BACKGROUND}

\section{D1.1 OVERVIEW}

The Contact-Handled Transuranic Mixed (CH-TRUM) Waste Packaging Unit (WPU) is a supplemental technology developed by CH2M HILL to receive, dry, and package CH-TRUM waste from tank farm single-shell tank (SST) systems.

Waste from the 241-B and 241-T Tank Farm tanks will be retrieved using the SST waste retrieval system (WRS) (vacuum retrieval) and transferred to the CH-TRUM WPU for receipt, drying, packaging, and temporary storage prior to being shipped to the Waste Isolation Pilot Plant (WIPP). The dried waste will be packaged in 55-gal drums and moved via forklift to a temporary storage facility where it will be kept prior to shipment to the Hanford Central Waste Complex (CWC).

\section{D1.2 SYSTEM DESCRIPTION}

The CH-TRUM WPU is a modular, portable, nuclear processing system designed to receive and package waste retrieved from 11 SSTs located in the 200 East and 200 West Areas. The 11 tanks are 241-B-201, 241-B-202, 241-B-203, 241-B-204, 241-T-201, 241-T-202, 241-T-203, 241-T-204, 241-T-104, 241-T-110, and 241-T-111. The WPU will be set up and operated initially at the 241-B Tank Farm in the 200 East Area. Upon completion of processing at the 241-B Tank Farm, the WPU will be relocated to the 241-T Tank Farm in the 200 West Area.

The WPU is sized to process 1.4 million gal of undiluted waste retrieved from 11 SSTs. The mission is to complete the packaging of the SST waste in approximately $1 \mathrm{yr}$, including a 30-day transfer of the WPU from the 241-B Tank Farm to the 241-T Tank Farm. The operational throughput capacity of the system will be 10,000 gal/day of diluted (nominal 1:1 dilution) tank waste although the system will be designed to handle 12,000 gal/day. Additives will be used, as necessary, to control the properties of the dried product and insure a flowable material that can be transported in the conveyance chute.

The slurry is dried to a target weight percent water in the waste dryer. A batch of the dried material, enough to fill a 55-gal drum to $85 \%$ capacity, is fed through the spherical cone valve at the waste dryer discharge and metered by a rotary valve into the hopper. Once the requisite amount of dried waste has been fed to the hopper, the cone valve is closed and the rotary valve 


\section{RPP-20725 REV 2}

stopped. Subsequently, another cone valve and rotary valve pair at the outlet to the hopper meter the dried waste into the drum.

The hopper and the lower part of the discharge chute, including the lower cone and rotary valves, are contained in a ventilated space with gloved ports for installing and deinstalling the connection of the bag to the discharge chute. The drum is sealed to the bottom of this confinement box prior to connecting the bag to the discharge chute. Once the drum is installed, it becomes part of the secondary confinement during filling operations.

After the requisite amount of dried waste has been delivered into the bag, the operators cut the bag below the discharge chute, close off the top, fold the top into the drum and swipe the outside of the bag for spreadable contamination. The drum is then decoupled from the confinement box and lowered onto a wheeled dolly. The steel lid is replaced on the bottom of the confinement box to close off the hole. The drum on the dolly is then rolled out into the lidding area, the lid and ring are installed and the ring tightened, and the drum is given a final swipe for spreadable contamination.

An estimated 7,550 55-gal drums (RPP-20499, System Design Description for the ContactHandled Transuranic Mixed Waste Packaging Unit and Support Equipment Project) will be filled for final disposal at the WIPP. The condensate resulting from the dryer operation will be sent to the Effluent Treatment Facility by tanker truck or returned to the WRS. The operating mission is expected to be completed in approximately $1 \mathrm{yr}$ after startup.

\section{D1.3 REPRESENTATIVE ACCIDENTS}

Hazardous conditions were identified that potentially could not be represented by an established representative accident (RPP-23479, Preliminary Documented Safety Analysis for the ContactHandled Transuranic Mixed (CH-TRUM) Waste Facility). These hazardous conditions were all related to postulated dry material releases from the Dewatering System (DWS), the Waste Packaging System (WPS) or the Off-Gas Treatment System (OGTS). The release of dried radioactive waste materials representative accident qualitatively considered in this technical basis document is a failure of the dried material conveyance system, which results in the release of dried waste to the atmosphere. This condition was selected since the potential drop heights from the DWS bound those of the WPS.

\section{D1.3.1 Associated Hazardous Conditions}

In addition to the hazardous conditions that define the representative accident, the hazard evaluation database lists other hazardous conditions that are characterized by the representative accident. The conditions include release of dried solids from the WPS, release of dried solids from the waste dryer, release of dried solids from the containment box due to a failed or missing seal to the 55-gal drum, release of dried solids due to drum spill before the lid is installed, spill of waste from the waste dryer through the waste conveyance system to the WPU floor (drum not present and waste conveyance valves not present or not closed), release of dried waste from the 
WPS due to a failed or missing seal to the 55-gal drum, release of dried waste from the WPS due to the drum not being in place (operator error), a small fire (e.g., resulting from a vehicle impact or a hydraulic system leak) that causes weakening and failure of the waste dryer steel superstructure resulting in a fall of dried waste from greater than $3 \mathrm{~m}$, and release of dried solids from the OGTS due to filtration failure.

\section{D2.0 RISK BINNING EVALUATION}

During meetings conducted January 27, 2005, and February 16, 2005, consensus was obtained on the assignment of frequencies, consequences, and controls. The meeting attendees represented a wide range of expertise in the areas of engineering, licensing, and operations. Appendix $\mathrm{E}$ lists the meeting attendees. The risk binning results for scenarios considered in this document are shown in Table D2-1.

\section{D2.1 REPRESENTATIVE ACCIDENT: FAILURE OF WASTE DRYER OR DRIED WASTE CONVEYANCE SYSTEM WITH FALL HEIGHT GREATER THAN 3 M}

\section{Accident Scenario}

As part of the CH-TRUM WPU, waste will be dried and packaged in 55-gal drums for disposal at the WIPP. Dried waste is transferred from the dryer to the WPS via the waste conveyance system. Each dryer is mounted on a steel superstructure directly over its respective WPS with the bottom of the dryer approximately $18 \mathrm{ft}$ above grade level. In the accident scenario, solids are released to drop on the ground from a failure in the waste conveyance system. The release could occur at any point between the dryer and the 55-gal drum. The result is release of the dried material to the atmosphere. It is conservatively assumed that there is no confinement and the solids move as a free-flowing powder.

\section{Frequency Determination}

Failure of the dried material conveyance system could be the result of one of several possible causes, including vehicle impacts, a seismic event, manufacturing defects, small fire, or installation errors. The design basis earthquake has a return period that puts it in the "unlikely" frequency range. Failures due to manufacturing defects or installation errors are judged to be "unlikely" because the equipment will be new, and the facility has a limited operating life. Additionally, all systems will be tested during startup prior to operating with the tank waste. Even though vehicle accidents are considered anticipated events, the dried material conveyance system is in a location that is relatively inaccessible by vehicle traffic. Therefore, the event was assigned a frequency bin of "unlikely." 


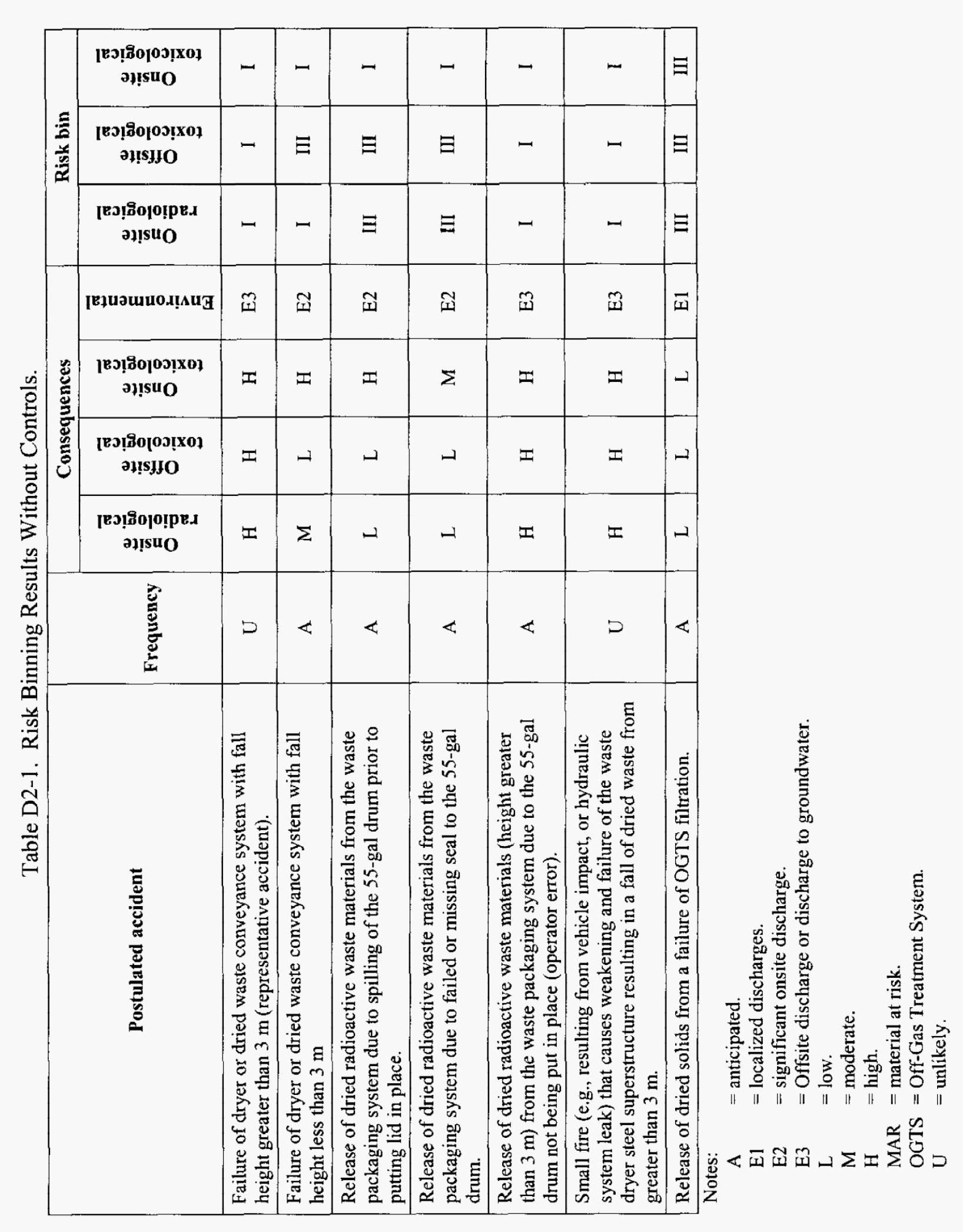

RPP-20725 REV 2

RPP-20725 REV 2

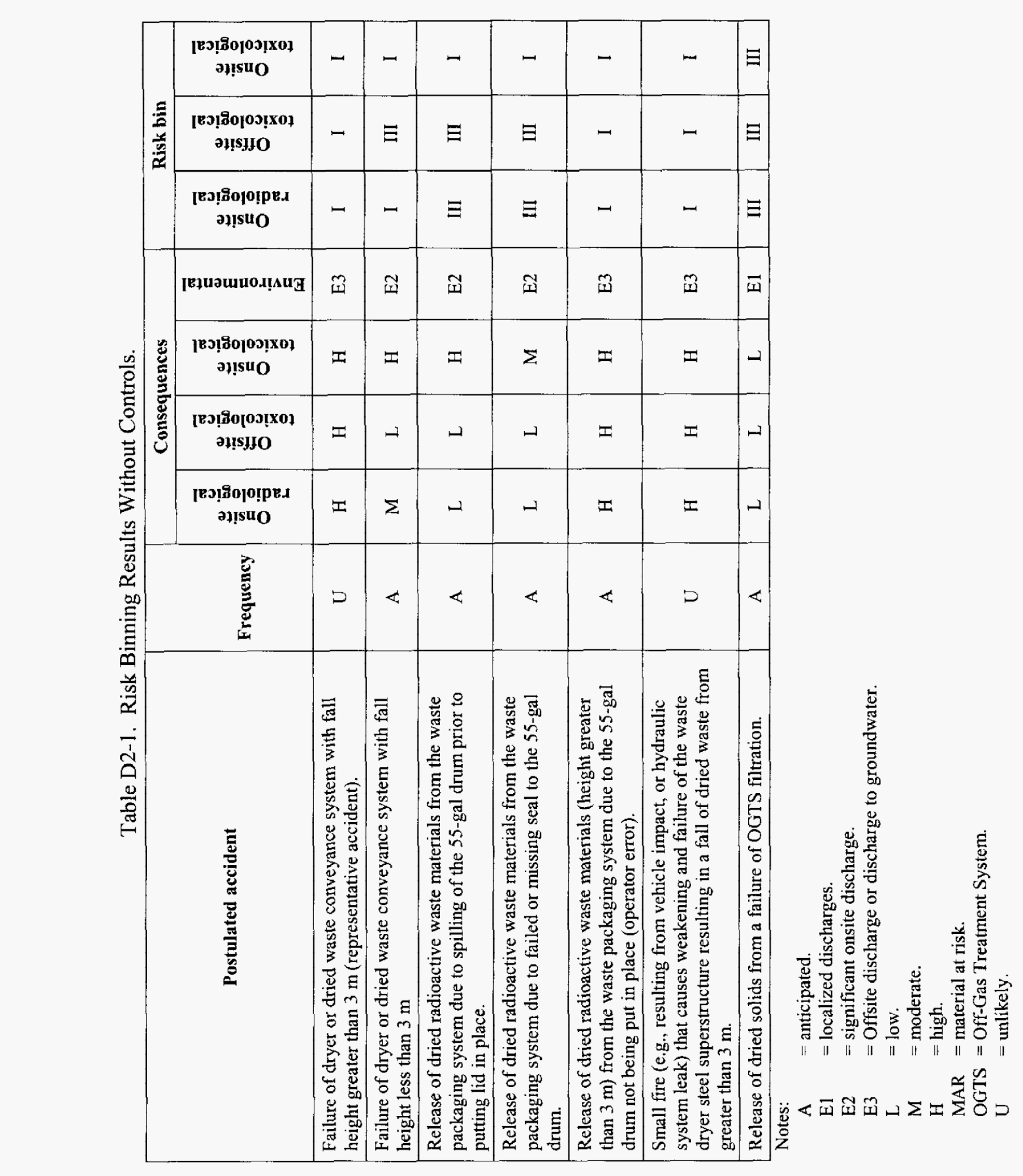




\section{Consequence Determination}

To provide an estimate of the radiological and toxicological consequences, scoping calculations were performed that are documented in Appendix F. The accident scenario, without controls, assumes failure of the dried material conveyance system that is used to transport the dried waste from the DWS to the plastic liner of a 55-gal drum. The waste is spilled from the dried material conveyance system to a hard, unyielding surface open to ambient conditions.

The spill is assumed to contain a complete dryer batch $(6,120 \mathrm{~L})$ of dried sludge from the bounding $\mathrm{CH}-\mathrm{TRUM}$ tank. The waste is assumed to be dried to $0 \mathrm{wt} \%$ water instead of the planned 3-20 wt \% water. This assumption maximizes the unit-liter dose (ULD) for the dried waste.

The radiological ULDs for the CH-TRUM tank waste were taken from RPP-5924, Radiological Source Terms for Tank Farms Safety Analysis, and the toxicological sum of fraction (SOF) multipliers were taken from RPP-8369, Chemical Source Terms for Tank Farms Safety Analyses. The atmospheric dispersion factors are from RPP-13482, Atmospheric Dispersion Coefficients and Radiological and Toxicological Exposure Methodology for Use in Tank Farms, and the airborne release fraction, respirable fraction, and airborne release rate are from DOE-HDBK-3010-94, Airborne Release Fractions/Rates and Respirable Fractions for Nonreactor Nuclear Facilities.

A complete list of the analysis assumptions, the potential effect of changes in the assumption, and the need to evaluate or protect the assumptions are presented in Table D2-2.

\section{Assignment of Consequence Bins}

Although the evaluation of consequences was intended to be qualitative, the radiological and toxicological characteristics of the CH-TRUM material at risk (MAR) are significantly different from those of previous analyses of releases of dried radioactive waste powder. Therefore, the previous analyses did not provide a frame of reference for the qualitative judgment. Therefore, the consequences were estimated based on scoping calculations shown in Appendix F.

Tables D2-3 and D2-4 compare the calculated consequences of the representative accident to the radiological and toxicological risk evaluation guidelines. The onsite radiological consequences were above both the $25 \mathrm{rem}$ guideline and the $100 \mathrm{rem}$ guideline; therefore, they were assigned to a consequence bin of "high." Both, the onsite and offsite toxicological consequences were shown to be above both the "moderate" and the "high" guidelines and were assigned to a consequence bin of "high." 
RPP-20725 REV 2

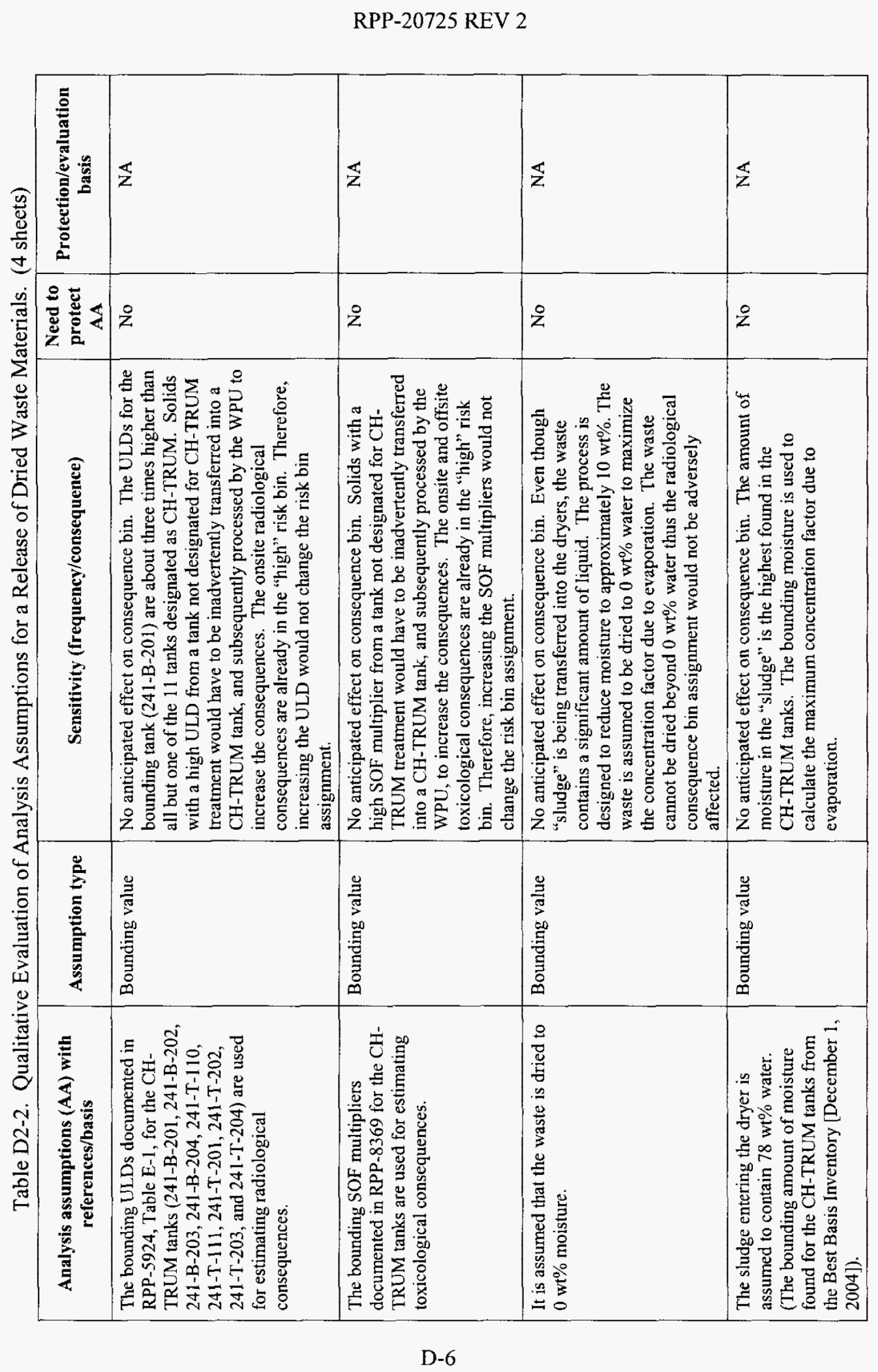




\section{RPP-20725 REV 2}

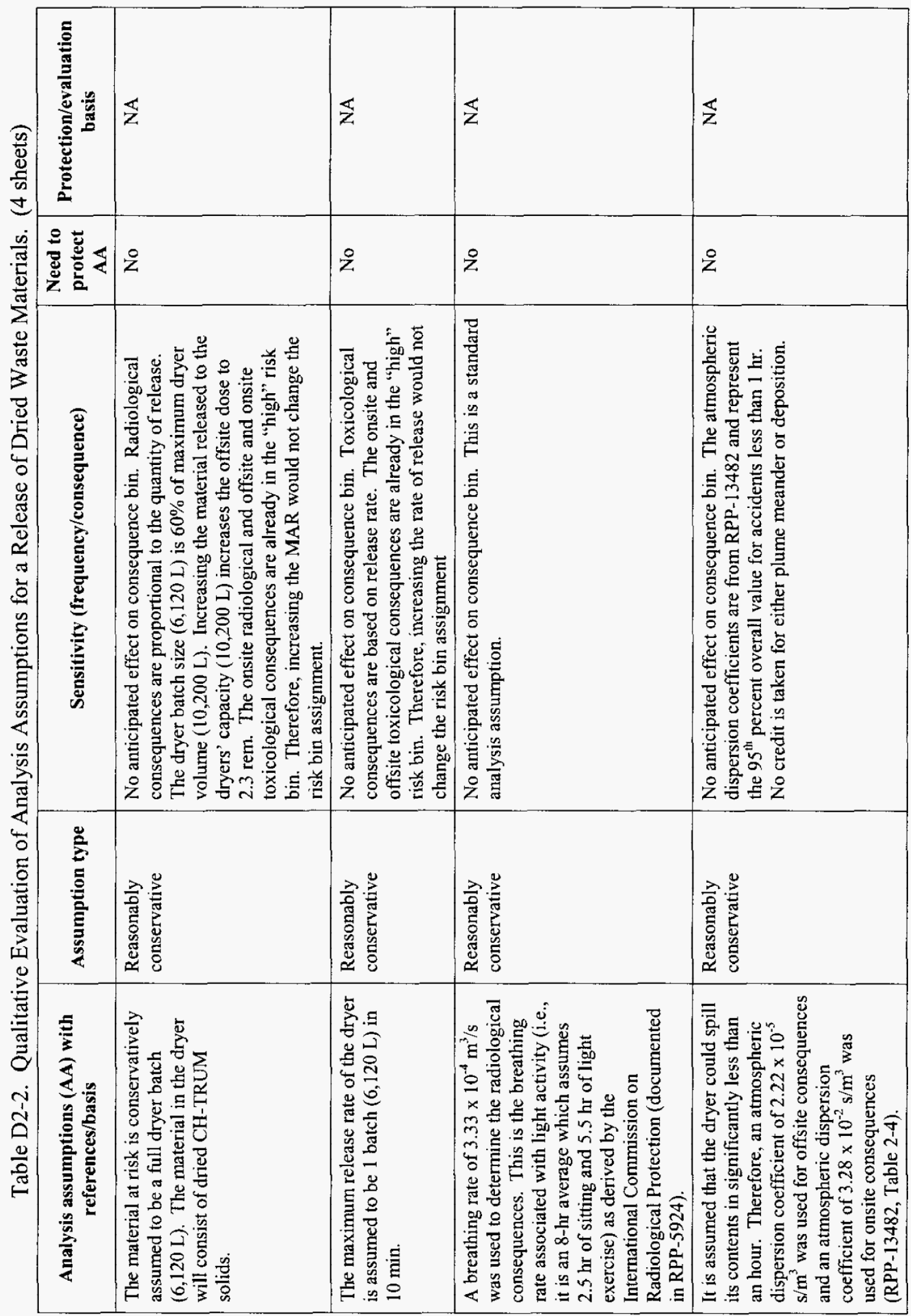

D-7 
RPP-20725 REV 2

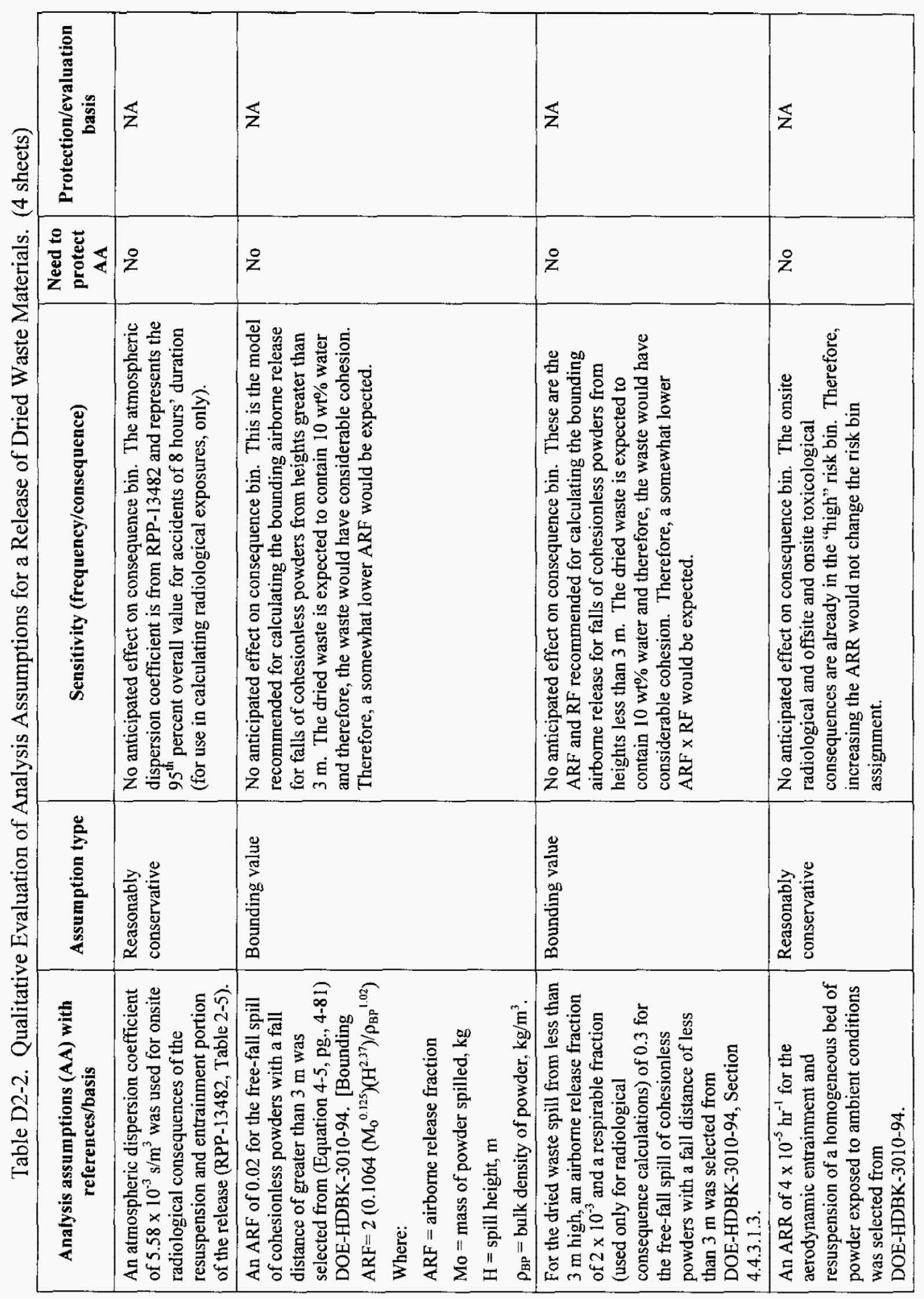

D-8 
RPP-20725 REV 2

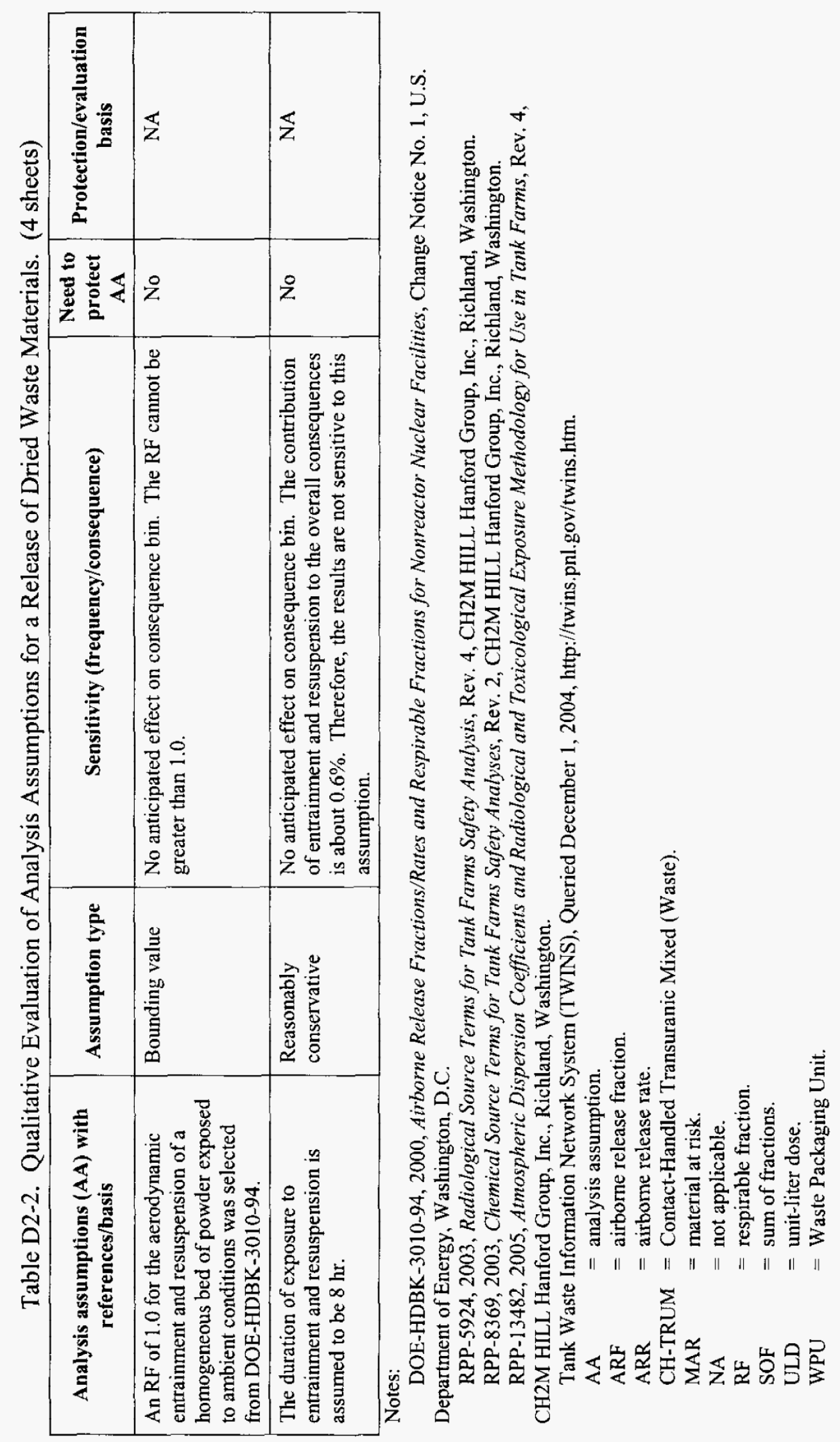

D-9 
Table D2-3. Summary of Onsite Radiological Consequences Without Controls for the Release of Dried Radioactive Waste Materials Representative Accident.

\begin{tabular}{|l|c|c|c|}
\hline \multirow{2}{*}{ Case } & \multicolumn{3}{|c|}{ Onsite radiological consequences } \\
\cline { 2 - 4 } & $\begin{array}{c}\text { Calculated dose } \\
\text { (rem) }\end{array}$ & $\begin{array}{c}\text { Moderate } \\
\text { consequence } \\
\text { guideline } \\
\text { (rem) }\end{array}$ & $\begin{array}{c}\text { High consequence } \\
\text { guideline } \\
\text { (rem) }\end{array}$ \\
\hline $\begin{array}{l}\text { Release of dried radioactive waste } \\
\text { materials }\end{array}$ & 1,300 & 25 & 100 \\
\hline
\end{tabular}

Table D2-4. Summary of Toxicological Consequences Without Controls for the Release of Dried Radioactive Waste Materials Representative Accident.

\begin{tabular}{|c|c|c|c|c|c|c|c|c|}
\hline \multirow{4}{*}{ Case } & \multicolumn{8}{|c|}{ Toxicological Consequences } \\
\hline & \multicolumn{4}{|c|}{ Onsite } & \multicolumn{4}{|c|}{ Offsite } \\
\hline & \multicolumn{2}{|c|}{$\begin{array}{c}\text { Moderate } \\
\text { consequence }\end{array}$} & \multicolumn{2}{|c|}{ High consequence } & \multicolumn{2}{|c|}{ Moderate consequence } & \multicolumn{2}{|c|}{ High consequence } \\
\hline & SOF & Guideline & SOF & Guideline & SOF & Guideline & SOF & Guideline \\
\hline $\begin{array}{l}\text { Release of } \\
\text { dried radio- } \\
\text { active waste } \\
\text { materials }\end{array}$ & 3,800 & 1 & 2,300 & 1 & 7.9 & 1 & 2.6 & 1 \\
\hline
\end{tabular}

Note:

SOF $=$ sum of fractions.

\section{Assignment of Environmental Consequences}

An environmental consequence of $\mathrm{E} 3$ was assigned since a discharge of $6,120 \mathrm{~L}$ of powder was shown to have the potential for offsite discharge.

\section{Assignment of Risk Bins without Controls}

Table D2-1 summarizes the frequency, consequence, and risk bin assignments for the release of dried radioactive waste materials representative accident. The assignment of risk bins is derived from the consequences and estimated frequency of the accident. The risk bin for the offsite toxicological receptor is I because the consequence is "high" and the estimated frequency is "unlikely." The risk bin for the onsite toxicological receptor is I because the consequence is "high" and the estimated frequency is "unlikely." The onsite radiological risk bin is I due to the "high" consequences and "unlikely" frequency. 


\section{RPP-20725 REV 2}

\section{D2.2 RELEASE OF DRIED RADIOACTIVE WASTE MATERIALS ASSOCIATED HAZARDOUS CONDITIONS}

The results of the risk binning process for the hazardous conditions covered by the representative accident in this document are contained within the hazard evaluation database. The hazard evaluation database includes the basis for each consequence and frequency. Consensus was reached by the risk binning team that all the represented hazardous conditions were bounded with respect to consequences by the representative accident. However, the frequencies of the represented hazardous conditions were generally higher.

In addition to the hazardous conditions that define the representative accident, the hazard evaluation database lists other hazardous conditions that are characterized by the representative accident. These conditions include:

- Release of dried waste from the dried waste conveyance system or WPS (less than $3 \mathrm{~m}$ )

- Release of dried waste due to spilling a drum prior to installing the lid (less than $3 \mathrm{~m}$ )

- Release of dried waste from the waste dryer through the dried waste conveyance system to the WPS floor due to the drum not being in place (assumes the waste conveyance valves are not present or are not closed) (greater than $3 \mathrm{~m}$ ) (operator error)

- Release of dried waste from the WPS due to a failed or missing seal to the 55-gal drum (less than $3 \mathrm{~m}$ )

- A small fire (e.g., resulting from vehicle impact or hydraulic system leak) that causes weakening and failure of the waste dryer steel superstructure and release of dried waste (greater than $3 \mathrm{~m}$ )

- Release of dried solids from the OGTS due to filtration failure.

The risk binning team considered the process design as well as the conservatisms in the analysis when assigning consequence and frequency bins to the other represented hazardous conditions. The results are presented with the representative accident in Table D-1, and are discussed below.

\section{D2.2.1 Failure of Waste Dryer or Dried Waste Conveyance System with Fall Height Less than $3 \mathrm{~m}$}

\section{Scenario}

This condition can occur when a breach occurs in the dried waste conveyance system or WPS at a location where the spill height of dried waste material is restricted by the presence of a solid surface less than $3 \mathrm{~m}$ below the breach. The event could be caused by a number of initiators, including vehicle impact, a seismic or other natural phenomena hazard event, material defects or mechanical failures. The waste would drop from the dried waste conveyance system to the solid 


\section{RPP-20725 REV 2}

surface resulting in the generation of radioactive "dust" as well as a small amount of entrainment and resuspension due to air movement.

\section{Frequency Determination}

Failure of the dried waste conveyance system or WPS (e.g., dried waste hopper, dried waste hopper secondary confinement box) could be the result of one of several possible causes, including vehicle impacts, a seismic event, manufacturing defects, or installation errors. The design basis earthquake has a return period that puts it in the "unlikely" frequency range. Failures due to manufacturing defects or installation errors are judged to be "unlikely" because the equipment will be new, and the facility has a limited operating life. However, vehicle accidents are considered anticipated events because this portion of the conveyance system is accessible to vehicle traffic and is subject to spills less than $3 \mathrm{~m}$ above grade (e.g., dried waste hopper, WPS). Therefore, the event was assigned a frequency of "anticipated."

\section{Consequence Determination}

Scoping calculations, shown in Appendix F, give a conservative estimate of the consequences for this scenario. The onsite radiological consequences were estimated to be "moderate." The offsite toxicological consequences were estimated to be "low." The onsite toxicological consequences were estimated to be "high."

\section{Assignment of Risk Bins Without Controls}

Table D2-1 summarizes the frequency, consequences, and risk bin without controls for this postulated dried waste release accident scenario.

An "anticipated" frequency and "moderate" consequence results in this scenario being categorized as Risk Bin I for onsite radiological consequences. An "anticipated" frequency and "high" consequence results in this scenario being categorized as Risk Bin I for onsite toxicological consequences. An "anticipated" frequency and "low" consequence results in this scenario being categorized as Risk Bin III for offsite toxicological consequences.

\section{D2.2.2 Release of Dried Waste from the Waste Packaging System Due to a Drum Spill}

In this scenario a release of dried waste results from tipping over a drum before the lid is installed. The failure is due to operator error. The material in the drum would drop to the floor of the International Organization for Standardization (ISO) container releasing a fraction of the spill into the air.

\section{Frequency Determination}

The frequency for a drum spill that results in the release of dried radioactive waste materials could be caused by human error. Therefore, the spill was judged to be "anticipated." 


\section{Consequence Determination}

This scenario is similar to the spill of dried waste from the conveyance system at a height of less than $3 \mathrm{~m}$ from the spill surface. The MAR in this case is the contents of a single 55 -gal drum. It is conservatively assumed that the drum was erroneously filled beyond the $85 \%$ full operating limit to its full capacity ( $55 \mathrm{gal}$ ). The onsite radiological consequence was estimated to be "low." The onsite toxicological consequence was estimated as "high," and the offsite toxicological consequence was estimated as "low."

\section{Assignment of Risk Bins Without Controls}

Table D2-1 summarizes the frequency, consequences, and risk bin without controls for this postulated dried waste release accident scenario.

An "anticipated" frequency and "high" consequence results in this scenario being categorized as Risk Bin I for onsite toxicological consequences. An "anticipated" frequency and "low" consequence results in this scenario being categorized as Risk Bin III for onsite radiological and offsite toxicological consequences.

\section{D2.2.3 Release of Dried Waste from the Waste Packaging System Due to Failed or Missing Seal to the 55-Gal Drum}

\section{Scenario}

This scenario postulates that dried waste material could leak into the WPS container during processing if operators were to attempt to initiate waste transfer with a failed seal between the drum and the WPS secondary confinement box.

\section{Frequency Determination}

This condition would likely be due to human error. Therefore, a frequency bin of "anticipated" was assigned.

\section{Consequence Determination}

No quantification of consequences of this scenario was made. Leakage, if any, from the gap between the drum and WPS secondary confinement box is expected to be bounded by the spill from the dried material conveyance system or the WPS (less than $3 \mathrm{~m}$ ) scenario (Section D2.2.1.) The consequence bins were qualitatively assigned to be lower than those assigned for the spills and falls of dried waste from heights of less than $3 \mathrm{~m}$ because the seal leak scenario is postulated to result in a smaller release of dried material. The onsite radiological and the offsite toxicological bins are "low." The onsite toxicological risk bin is qualitatively assigned to be "moderate." 


\section{Assignment of Risk Bins Without Controls}

Table D2-1 summarizes the frequency, consequences, and risk bin without controls for this postulated dried waste release accident.

An "anticipated" frequency and "moderate" consequence results in this scenario being categorized as Risk Bin I for onsite toxicological consequences. An "anticipated" frequency and "low" consequence results in this scenario being categorized as Risk Bin III for onsite radiological and offsite toxicological consequences.

\section{D2.2.4 Release of Dried Radioactive Waste from the Waste Packaging System Due to the Drum not in Place}

\section{Scenario}

In this scenario a release of dried waste results from a failure to have the plastic drum liner and drum connected to the conveyance chute before commencing dried waste transfer. The bounding assumption for this scenario is that the spill could be from the dryer, down an unobstructed pathway through the conveyance system to the floor of the ISO container. The bounding result is the same as for the spill of dried waste from a height greater than $3 \mathrm{~m}$.

\section{Frequency Determination}

The frequency without controls for a failure to ensure the liner and drum are in place before commencing waste conveyance operations is judged to be "anticipated" because it would be caused by human error.

\section{Consequence Determination}

The consequences for this scenario were conservatively estimated to be the same as for the representative accident. The onsite radiological, and onsite and offsite toxicological consequences were estimated to be "high."

\section{Assignment of Risk Bins Without Controls}

Table D2-1 summarizes the frequency, consequences, and risk bin without controls for this postulated dried waste release accident scenario.

An "anticipated" frequency and "high" consequence results in this scenario being categorized as Risk Bin I for onsite toxicological consequences. An "anticipated" frequency and "high" consequence results in this scenario being categorized as Risk Bin I for onsite radiological and offsite toxicological consequences. 


\section{D2.2.5 Release of Dried Waste (Height Greater than \\ $3 \mathrm{~m}$ ) Due to Small Fire-Induced Dryer Superstructure Failure and Subsequent Waste Dryer Collapse}

\section{Scenario}

In this scenario, a small fire (e.g., resulting from a vehicle impact or a hydraulic system leak) causes weakening and failure of the steel superstructure supporting the waste dryer resulting in a collapse of the waste dryer and a subsequent fall of dried waste from greater than $3 \mathrm{~m}$.

\section{Frequency Determination}

Based on operational experience, fires involving vehicles have occurred in the past, but were not of the type that directly involved waste or waste containers such as those described by the postulated representative accident. In addition, RPP-24217, Technical Basis Report for Large Fire Accidents Involving Aboveground Tanks/Vessels, judges leaks from the CH-TRUM hydraulic system to be "unlikely." Thus, the tank waste container fire scenario is judged to be less than anticipated and the accident is qualitatively assigned a frequency of "unlikely."

\section{Consequence Determination}

The consequences for this scenario were conservatively estimated to be the same as for the representative accident. The onsite radiological consequences were estimated to be "high." The onsite and offsite toxicological consequences were estimated to be "high."

\section{Risk Bin Results Without Controls}

Table D2-1 summarizes the frequency, consequences, and risk bin without controls for this postulated dried waste release accident. An "unlikely" frequency and "high" consequence results in this scenario being categorized as Risk Bin I for onsite radiological and onsite and offsite toxicological consequences.

\section{D2.2.6 Release of Dried Waste from the Off-Gas Treatment System Due to Filtration Failure}

\section{Scenario}

In this scenario the OGTS high-efficiency particulate air (HEPA) filters (and prefilters) fail due to high temperature or high pressure, causing a partial release of the maximum waste loading on the filters. This is followed by an 8-hr unfiltered release from the CH-TRUM WPU at the maximum exhauster flow rate. 
An 8-hr unfiltered release could also occur at the maximum exhauster flow rate due to an error during filter maintenance, gross leakage around a misaligned filter, or damage to the ductwork. This release is also included in the first two scenarios, but in this third scenario there is no release from the filters.

\section{Frequency Determination}

The HEPA over-temperature accident may occur as a result of a ventilation system heater failure or an external fire. The HEPA over pressure accident is similar to an event believed to have occurred in the past when a filter became saturated with moisture and was subsequently damaged when the ventilation fans were activated. The unfiltered release path could occur from several causes, including human error during filter maintenance. Therefore, the event is assigned a frequency of "anticipated."

\section{Consequence Determination}

The consequences of the two filter failure scenarios (high temperature and high pressure) are dominated by the portion of the consequences that come from the 8 -hr unfiltered release following the filter failure event. Therefore, the consequences of $8 \mathrm{hr}$ of leakage around the filter are essentially the same as the consequences of the filter failure scenarios. The onsite radiological and the onsite and offsite toxicological consequences are estimated to be in the "low" consequence bin.

\section{Risk Bin Results Without Controls}

Table 2-1 summarizes the frequency, consequences, and risk bin without controls for this postulated dried waste release accident. An "anticipated" frequency and "low" consequence results in this scenario being categorized as Risk Bin III for onsite radiological and onsite and offsite toxicological consequences.

\section{D3.0 CONTROL SELECTION}

Control selection was accomplished in formal risk binning and control selection meetings held on April 2, 2004, January 27, 2005, and February 16, 2005, and in an email sent March 3, 2005, to the control selection group by Nuclear Safety and Licensing in which additional control recommendations were made. Meeting attendees represented an appropriate range of expertise and relevant experience in the areas of transportation, waste handling, licensing, and operations.

The results of scoping calculations used to develop the accident analysis documented herein were available to the control decision meeting attendees to assist in the decision process. The meeting attendees and their respective organizational affiliation are listed in Appendix $\mathrm{E}$. The email sent to the control decision group is also included in Appendix E. Risk binning and control decision results were documented in meeting minutes. The specific risk binning results are discussed in Section D2.0, and the specific control selection results are discussed in the following sections. 


\section{D3.1 PROPOSED CONTROLS FOR THE RELEASE OF DRIED RADIOACTIVE WASTE MATERIALS REPRESENTATIVE ACCIDENT}

A summary of the consequence analysis of the representative accident and associated hazardous conditions, as well as a discussion of the risk binning results, was presented to the control selection team. The group then proposed and discussed potential controls for the representative accident and the associated hazardous conditions. The discussion focused on two potential controls schemes.

The first control strategy considered was referred to as "active confinement." It consisted of secondary confinement of the dried waste streams coupled with active ventilation to provide negative pressure within the confinement thus preventing leaks outside of the confinement. The ventilation would exhaust through a HEPA filter to remove any suspended waste.

The second control strategy was referred to as "passive confinement." This strategy also uses secondary confinement, but does not rely on active ventilation. In this strategy, the secondary confinement would be tested for bypass leakage to ensure that any spill within the confinement would not be released to the environment through a non-filtered path.

The third and final (selected) control strategy considered involves the use of active secondary confinement in the DWS ISO freight container provided by a single safety-significant OGTS exhauster, with safe shutdown of the waste dryer upon loss of negative differential pressure. Although safe shutdown of the waste dryer is required on a loss of active secondary confinement, a significant amount of waste will necessarily remain in the dryer. Therefore, an additional level of protection is provided by the use of passive secondary confinement, comprising the DWS ISO freight container and inlet HEPA filter.

\section{D3.2 SELECTED CONTROLS FOR THE RELEASE OF DRIED RADIOACTIVE WASTE MATERIALS REPRESENTATIVE ACCIDENT}

\section{D3.2.1 Control Selection}

The proposed controls were discussed and evaluated by the group. Control decision criteria are established in:

- Title 10, Code of Federal Regulations, Part 830, "Nuclear Safety Management" Subpart B, (10 CFR 830) 
- DOE-STD-3009-94, Preparation Guide for U.S. Department of Energy Nonreactor Nuclear Facility Documented Safety Analyses

- DOE G 421.1-2, Implementation Guide for Use in Developing Documented Safety Analyses to Meet Subpart B of 10 CFR 830

- DOE G 423.1-1, Implementation Guide for Use in Developing Safety Requirements

- Klein and Schepens 2003, "Replacement of Previous Guidance Provided by RL and ORP".

The control decision preference can be summarized as follows:

1. Preventive controls over mitigative

2. Passive controls over active control

3. Engineering controls over administrative controls

4. Controls with the highest reliability

5. Controls closest to the hazard

6. Controls with the lowest implementation and maintenance costs.

\section{D3.2.2 Selected Control Strategy}

Credited Design Features for this strategy prevent dried waste releases directly to the atmosphere. The dryers and connecting lines to the conveyor that are within the ISO freight container (a waste transfer-associated structure) shall maintain their confinement for anticipated environmental and operating conditions. The waste conveyance system primary confinement must contain the dried waste and the secondary confinement must confine dried waste releases from primary confinement failures. The secondary conveyance system confinement is relied on to mitigate a dried waste release from the primary confinement.

The safety structures, systems, and components (SSC), technical safety requirement (TSR) controls, and design features selected for preventing or mitigating dried waste release accidents during CH-TRUM WPU operations are summarized below. For each safety SSC and TSR, the safety function is described.

\section{Safety Significant SSCs}

Safety-significant SSCs for the representative accident, failure of the waste dryer or dried waste conveyance system resulting in a dried waste spill from a height greater than $3 \mathrm{~m}$, include:

- Waste dryer confinement.

- Dried waste conveyance system between the waste dryer and the plastic liner of the drum (includes piping, valves and the hopper).

- Dried waste hopper secondary confinement box. 


\section{RPP-20725 REV 2}

- WPS secondary confinement box system.

- Interlock to close valve(s) to stop dried waste flow on loss of vacuum in the hopper secondary confinement box and WPS confinement box/drum system, thus limiting the release. This interlock system will meet single-failure criteria. This control would also be used to mitigate the hazard of initiating waste transfer when a drum is not in place.

- DWS ISO freight container.

- Dried waste hopper/WPS secondary confinement vacuum interlock system.

- DWS ISO freight container ventilation system.

- DWS ISO freight container negative pressure monitoring and alarm system.

- DWS ISO freight container inlet HEPA filter.

- DWS ISO freight container OGTS HEPA filter.

- Waste dryer discharge valve.

- Dried waste hopper discharge valve.

- Vehicle barriers.

Because the accident could be initiated by a seismic event or other natural phenomena hazards, the designation of the waste dryer, the conveyance system, the hopper secondary confinement box, the WPS confinement box system, the DWS ISO freight container, the DWS ISO freight container ventilation system and the DWS ISO freight container HEPA filters are designed to performance category-2 (PC-2) natural phenomenon hazard requirements.

The safety function of the waste dryer and the dried waste conveyance system including the hopper, piping and valves, is to maintain primary confinement of the dried waste under postulated accident conditions, thus decreasing the frequency of a dried waste accident.

The safety function of the DWS ISO freight container, the DWS ISO container ventilation system, the dried waste hopper secondary confinement box, and the WPS secondary confinement box system, the DWS ISO freight container inlet HEPA filter and the DWS ISO freight container OGTS filter is to provide secondary confinement of the dried waste in the event of a primary system breach, thus decreasing the consequences of a dried waste accident.

The safety function of the DWS ISO freight container ventilation system is to maintain a negative pressure in the DWS ISO freight container, thus decreasing the consequences of a release of dried waste accident. The safety function of the DWS ISO freight container inlet and OGTS HEPA filters is to provide HEPA filtration, thus decreasing the consequences of a release of a dried waste accident. HEPA filters shall provide a minimum $99.95 \%$ efficiency. The DWS ISO freight container negative pressure monitoring and alarm system will provide an alarm signal to initiate operator response and safe shutdown of the waste dryer unless the pressure in 


\section{RPP-20725 REV 2}

the DWS ISO freight container is negative with respect to atmosphere, thus decreasing the frequency of a dried waste accident.

The safety function of the dried waste hopper/WPS secondary confinement vacuum interlock system is to prevent the release by closing off the flow path from the waste dryer to the conveyance system in the event of a loss of negative pressure differential with respect to atmosphere in the hopper/WPS secondary confinement boxes, thus decreasing the frequency of a dried waste accident. If operators were to attempt to initiate waste transfer without the drum in place or with a failed seal between the drum and the WPS confinement box, the interlock would prevent the release.

The safety function of the waste dryer discharge valve and the dried waste hopper discharge valve is to close, and to fail closed, when a loss of negative pressure signal is received from the dried waste hopper/WPS secondary confinement vacuum interlock system, thus decreasing the frequency of a dried waste accident.

The safety function of aboveground transfer vehicle barriers is to prevent dried waste releases from the waste dryers, the dried waste conveyance system, or an open drum caused by vehicle collision, thus decreasing the frequency of a dried waste accident.

\section{Technical Safety Requirements}

The TSR controls include new limiting condition for operation (LCO):

1. Dried waste hopper/WPS secondary confinement vacuum interlock system.

The safety function of this LCO is to ensure the operability of the dried waste hopper confinement/WPS secondary confinement vacuum interlock system, thus decreasing the frequency of a dried waste accident. The monitoring and interlock system is required to be operable when the dried waste material is being conveyed from the waste dryer into the plastic-lined drum. It will prevent or mitigate release of dried waste into the WPS ISO freight container by ensuring that waste transfer will stop, or will not be started, if the pressure in the dried waste hopper confinement or the in the WPS secondary confinement box is greater than the pressure in the WPS ISO container.

2. DWS ISO freight container ventilation system.

The safety function of this LCO is to ensure the DWS ISO freight container ventilation system is operable, thus decreasing the consequences of a dried waste accident. The ventilation system must operate to maintain the pressure in the DWS ISO freight container negative with respect to atmosphere whenever the waste dryer is operating.

3. DWS ISO freight container negative pressure monitoring and alarm system.

The safety function of this LCO is to ensure the operability of the DWS ISO freight container negative pressure monitoring and alarm system, thus decreasing the consequences of a dried waste accident. This system will alarm and alert operators to a 


\section{RPP-20725 REV 2}

condition of loss of negative pressure in the DWS ISO freight container, thus initiating operator response to safely shut down the waste dryer.

Additional TSR controls include the following administrative controls:

CH-TRUM WPU Controls:

- DWS ISO freight container inlet and OGTS HEPA filters efficiency testing

- DWS ISO freight container bypass leakage rate

- Waste dryer openings and seals

- DWS ISO freight container doors

- Vehicle impact barriers at all locations where a vehicle impact could lead to a spill of the dried waste material

Safety Management Programs:

- Hoisting and rigging safety management program

- Fire protection safety management program

- Emergency Preparedness Program.

Design Features include the following:

- Plastic liners for drums

- Drums

- Drum stabilizer.

\section{D3.2.3 Risk Bin Results With Controls}

Table D3-1 summarizes the frequency, consequences, and risk bin with controls for each postulated dried waste release accident scenario. The risk bin results with controls for each scenario are discussed below.

Failure of Waste Dryer or Dried Waste Conveyance System with Fall Height Greater than $3 \mathbf{m}$. Application of the stated controls is qualitatively judged to reduce the onsite and offsite toxicological consequences and the onsite radiological consequences of the dried waste release accident from the waste dryer or dried waste conveyance system to the "moderate" consequence category. In addition, the application of the controls is qualitatively evaluated to reduce the frequency of the dried waste release accident from greater than $3 \mathrm{~m}$, from "unlikely" to "extremely unlikely." Equipment built to PC-2 seismic design criteria should withstand the design basis earthquake which falls in the "unlikely" frequency range. Therefore, an earthquake of greater magnitude than the design basis earthquake would be an "extremely unlikely" occurrence. The accident scenario involving a spill from greater than $3 \mathrm{~m}$ high is thus reduced to Risk Bin III for offsite and onsite toxicological exposures and onsite radiological exposure. 


\title{
RPP-20725 REV 2
}

\begin{abstract}
Failure of Waste Dryer or Dried Waste Conveyance System with Fall Height Less than $3 \mathbf{m}$. Application of the stated controls is qualitatively judged to reduce the onsite radiological consequence to the "low" consequence category and the onsite toxicological consequence of the dried waste release accident from the waste dryer or dried waste conveyance system to the "moderate" consequence category. In addition, the application of the controls is qualitatively judged to reduce the frequency of the dried waste release accident for spills less than $3 \mathrm{~m}$, from "anticipated" to "unlikely." The accident scenario involving a spill from less than $3 \mathrm{~m}$ high is thus reduced to Risk Bin III for onsite radiological releases and Risk Bin II for onsite toxicological exposures.
\end{abstract}

Release of Dried Waste from the WPS Due to a Drum Spill. To address the dried waste release due to the tipping over of a full waste drum before the lid is in place, a drum stabilizer is provided as a design feature to prevent the accident. After filling, the 55-gal drum is pulled out from under the fill station containment box to a shielded area for reinstallation of the lid and where surveying and decontamination is performed if necessary. The "tip-resistant" design enhances the stainless steel shielding barrier so that it also provides drum stabilization to prevent tipping. In addition, the enhanced design also provides a broader wheel base on the dolly so that the drum cannot tip over as the result of an earthquake, or by being impacted by a vehicle. An earthquake of greater magnitude than the design basis earthquake would be required to tip over the drum. This earthquake has an "extremely unlikely" frequency of occurrence. The drum stabilizer design feature is therefore judged to reduce the accident frequency to "extremely unlikely," which combined with "high" onsite toxicological consequences, results in Risk Bin II.

Release of Dried Waste from the WPS Due to Failed or Missing Seal to the 55-Gal Drum. The controls selected for the representative dried waste release accident also work to prevent or mitigate the hazardous conditions associated with this scenario. Safety SSCs and TSRs for the waste dryer or dried waste conveyance system (greater than $3 \mathrm{~m}$ fall height) failure scenario are discussed in Section D3.2.2. The safety function of the dried waste hopper/WPS secondary confinement vacuum interlock system is to prevent the release by closing off the flow path from the waste dryer to the conveyance system in the event of a loss of negative pressure differential with respect to atmosphere in the hopper/WPS secondary confinement boxes, thus decreasing the frequency of a dried waste accident. If operators were to attempt to initiate waste transfer with a failed seal between the drum and the WPS confinement box, the interlock would prevent the release. An "unlikely" frequency and "low" consequences results in this scenario being categorized as Risk Bin III for onsite radiological and onsite and offsite toxicological consequences.

Release of Dried Radioactive Waste from the WPS Due to the Drum not in Place. The controls selected for the representative dried waste release accident also work to prevent or mitigate the hazardous conditions associated with the both of these scenarios. Safety SSCs and TSRs for the waste dryer or dried waste conveyance system (greater than $3 \mathrm{~m}$ fall height) failure scenario are discussed in Section D3.2.2. The safety function of the dried waste hopper/WPS secondary confinement vacuum interlock system is to prevent the release by closing off the flowpath from the waste dryer to the conveyance system in the event of a loss of negative pressure differential with respect to atmosphere in the hopper/WPS secondary confinement boxes, thus decreasing the frequency of a dried waste accident. If operators were to attempt to initiate waste transfer without the drum in place, the interlock would prevent the release. An 
"unlikely" frequency and "moderate" consequences results in this scenario being categorized as Risk Bin II for onsite radiological and onsite and offsite toxicological consequences.

\section{Release of Dried Waste (Height Greater than 3 m) Due to Small Fire-Induced Dryer} Superstructure Failure and Waste Dryer Collapse. The safety function of the fire protection safety management program is to prevent collapse of the steel superstructure supporting the waste dryer caused by a fire, thus decreasing the frequency of a release of dried waste accident. A fire resistant coating with a 2-hr fire rating on the waste dryer steel superstructure would satisfy the safety function. Application of the fire protection safety management program control is qualitatively judged to reduce the frequency of the fire-initiated dryer failure scenario from "unlikely" to "extremely unlikely," which combined with "high" consequences, results in Risk Bin II for onsite radiological and onsite and offsite toxicological exposures. 
RPP-20725 REV 2

\begin{tabular}{|c|c|c|c|c|c|c|c|c|}
\hline \multirow{3}{*}{ 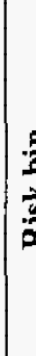 } & 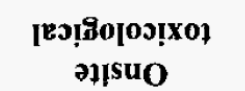 & 目 & $\approx$ & $\Xi$ & $\Xi$ & ヨ & $=$ & \\
\hline & 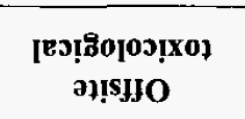 & 目 & $\Xi$ & $\Xi$ & 目 & $\Xi$ & $\Xi$ & \\
\hline & 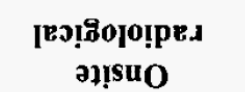 & 目 & $\Xi$ & $\Xi$ & 三 & $\Xi$ & $\Xi$ & \\
\hline \multirow{6}{*}{ 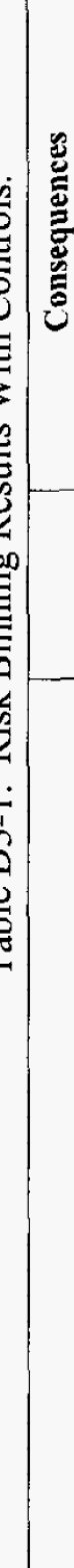 } & 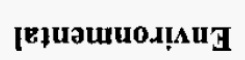 & $\Theta$ & $\widetilde{\Xi}$ & $\widetilde{I}$ & 포 & 琾 & 고 & \\
\hline & 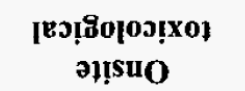 & $\Sigma$ & $\Sigma$ & 工 & ユ & $\Sigma$ & $\boldsymbol{I}$ & \\
\hline & 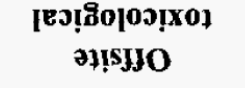 & $\Sigma$ & صـ & ન & ユ & $\Sigma$ & 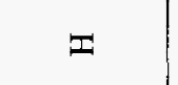 & \\
\hline & 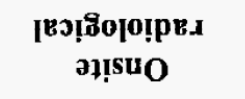 & $\Sigma$ & 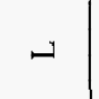 & 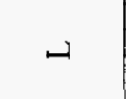 & - & $\Sigma$ & 工I & \\
\hline & 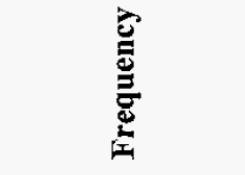 & 로 & $\supset$ & 茎 & $\supset$ & 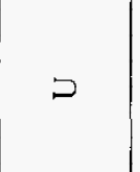 & ? & \\
\hline & 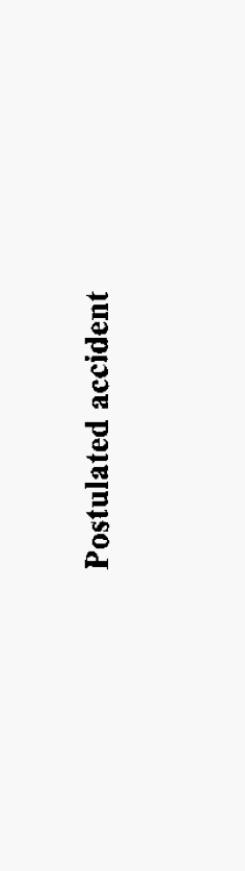 & 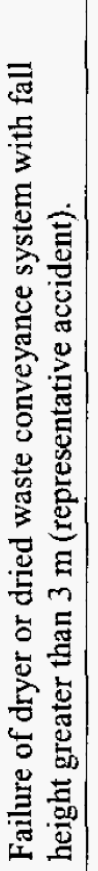 & 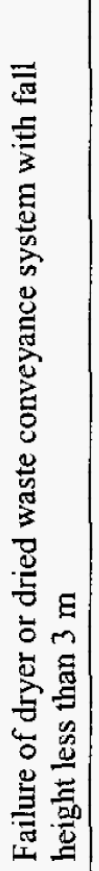 & 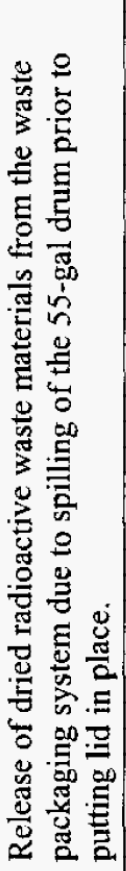 & 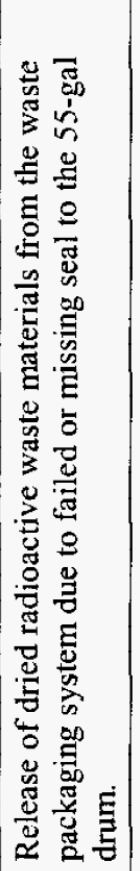 & 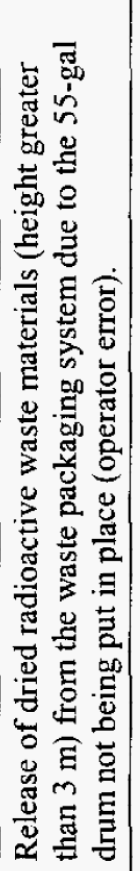 & 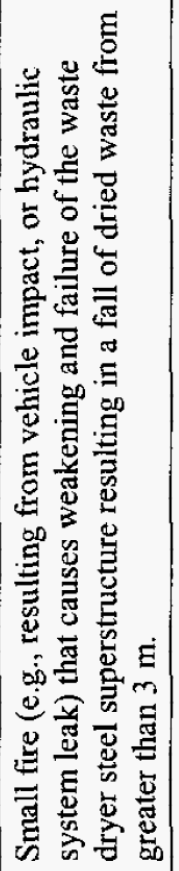 & 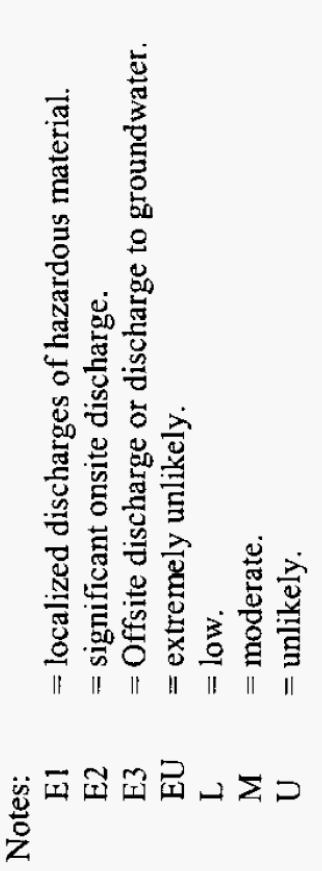 \\
\hline
\end{tabular}

RPP-2072 
RPP-20725 REV 2

\section{D4.0 REFERENCES}

10 CFR 830, "Nuclear Safety Management," Code of Federal Regulations, as amended.

DOE G 421.1-2, 2001, Implementation Guide For Use in Developing Documented Safety Analyses To Meet Subpart B of 10 CFR 830, U.S. Department of Energy, Washington, D.C.

DOE G 423.1-1, 2001, Implementation Guide For Use In Developing Technical Safety Requirements, U.S. Department of Energy, Washington, D.C.

DOE-HDBK-3010-94, 2000, Airborne Release Fractions/Rates and Respirable Fractions for Nonreactor Nuclear Facilities, Change Notice No. 1, U.S. Department of Energy, Washington, D.C.

DOE-STD-3009-94, 2002, Preparation Guide for U.S. Department of Energy Nonreactor Nuclear Facility Documented Safety Analyses, Change Notice No. 2, U.S. Department of Energy, Washington, D.C.

Klein, K. A., and R. J. Schepens, 2003, "Replacement of Previous Guidance Provided by RL and ORP," (letter 03-ABD-0047/0300462 to E. K. Thomson, Fluor Hanford Inc., and E. S. Aromi, CH2M HILL Hanford Group, Inc., February 4), U.S. Department of Energy, Richland Operations Office, Richland, Washington.

RPP-5924, 2005, Radiological Source Terms for Tank Farms Safety Analysis, Rev. 4A, CH2M HILL Hanford Group, Inc., Richland, Washington.

RPP-8369, 2003, Chemical Source Terms for Tank Farms Safety Analyses, Rev. 2, CH2M HILL Hanford Group, Inc., Richland, Washington.

RPP-13482, 2005, Atmospheric Dispersion Coefficients and Radiological and Toxicological Exposure Methodology for Use in Tank Farms, Rev. 5, CH2M HILL Hanford Group, Inc., Richland, Washington.

RPP-20499, System Design Description for the Contact-Handled Transuranic Mixed Waste Packaging Unit and Support Equipment Project, Rev. 0A, CH2M HILL Hanford Group, Inc., Richland, Washington.

RPP-23479, 2005, Preliminary Documented Safety Analysis for the Contact-Handled Transuranic Mixed (CH-TRUM) Waste Facility, Rev. 0, CH2M HILL Hanford Group, Inc., Richland, Washington.

RPP-24217, 2005, Technical Basis Report for Large Fire Accidents Involving Aboveground Tanks/Vessels, Rev. 1, CH2M HILL Hanford Group, Inc., Richland, Washington. 


\section{RPP-20725 REV 2}

This page intentionally left blank. 
RPP-20725 REV 2

\section{APPENDIX E}

CONTACT-HANDLED TRANSURANIC MIXED WASTE RISK BINNING/CONTROL ALLOCATION MEETING ATTENDEES 
RPP-20725 REV 2

This page intentionally left blank.

E-ii 
RPP-20725 REV 2

\title{
APPENDIX E
}

\section{CONTACT-HANDLED TRANSURANIC MIXED WASTE RISK BINNING/CONTROL ALLOCATION MEETING ATTENDEES}

CH-TRUM Control Decision Meeting Attendance Sheet

\begin{abstract}
Meeting Subject: Release of Dry Materials Accident
Date: April 2, 2004
\end{abstract}

\begin{tabular}{|c|c|c|}
\hline Name & Company/Organization & Phone \\
\hline Laweruke VI Keines & SAOM HIL $/$ NSWC & $37 \leq-106$ \\
\hline S. D. Kozbowsk & 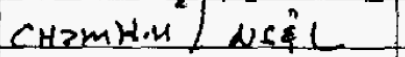 & $323-1360$ \\
\hline K. R. Sandgren & CHamHil/_NseL & 372.0374 \\
\hline$m=5$ Tensings & $\varepsilon H \geq m u$ ul & $372-1502$ \\
\hline IA wed & clt2m ctill Evvireorufs & $3>2-16 \mid>$ \\
\hline W.E. Bryan & CHzM 1kIRL/Eng. & $373-9740$ \\
\hline Deck whekehurst & DMIM $/ \varepsilon_{N}$ & 375.2883 \\
\hline Cempe tronceck & ctz $/$ Bo Att. & $376-2225$ \\
\hline$\in$ Reichmonth & CH2 $2 \mathrm{P}^{2}$ & $376-4796$ \\
\hline Mark Sautman & DNFSB site Rep & $373-0101$ \\
\hline Bick teatlo & $\mathrm{CH}_{2} \mathrm{MH}$ HII Foy & $376-3152$ \\
\hline & & \\
\hline & & \\
\hline & & \\
\hline & & \\
\hline & & \\
\hline & & \\
\hline & & \\
\hline & & \\
\hline & & \\
\hline & & \\
\hline & & \\
\hline & & \\
\hline & & \\
\hline & & \\
\hline & & \\
\hline & & \\
\hline
\end{tabular}

E-1 
RPP-20725 REV 2

\section{CONTROL DECISION MEETING ATTENDANCE}

Meeting Subject: $\mathrm{CH}$-TRUM Dried Waste Release

Meeting Date: 1/27/05

\begin{tabular}{|c|c|c|}
\hline Name & Organization & Telephone \\
\hline Steve Kozlowski & $\mathrm{CH} 2 \mathrm{M} / \mathrm{NS} \& \mathrm{~L}$ & $373-1360$ \\
\hline Jeni Cowin & $\mathrm{CH} 2 \mathrm{M} /$ Process Eng. & $372-1119$ \\
\hline Roger Nelson & $\mathrm{CH} 2 \mathrm{M} / \mathrm{TSC} / \mathrm{Op}$. Readiness & $539-5419$ \\
\hline Mike Sutey & CH2M/Eng Support & $373-2408$ \\
\hline Matt Landon & $\mathrm{CH} 2 \mathrm{M} /$ Engineering & $373-1379$ \\
\hline Jim Hoffman & $\mathrm{CH} 2 \mathrm{M} / \mathrm{Ops}$ & $373-9859$ \\
\hline Lawrence J. Kripps & $\overline{\mathrm{CH}} 2 \mathrm{M} / \mathrm{NS} \& \mathrm{~L}$ & $376-1061$ \\
\hline Wes Bryan & $\mathrm{CH} 2 \mathrm{M}$ & $373-9740$ \\
\hline Shawn Hailey & DMJM & $375-7868$ \\
\hline Dave King & DMJM/Tech Lead & $375-7855$ \\
\hline Dick Whitehurst & DMJM & $375-7883$ \\
\hline Maryanne Kummerer & CH2M/TRS/ NS\&L & $372-9586$ \\
\hline Melissa Holm & $\mathrm{CH} 2 \mathrm{M} / \mathrm{Eng}$ & $373-1098$ \\
\hline Mark VanderZanden & DMJM & $375-7885$ \\
\hline Rick Tedeschi & CH2M Hill & $373-6018$ \\
\hline Mark Sautman & DNFSB & $373-\overline{0101}$ \\
\hline Curt Reichmuth & $\mathrm{CH} 2 \mathrm{M} / \mathrm{Ops}$ & $376-4796$ \\
\hline Dennis Carson & CH2M/QAE & $372-8875$ \\
\hline Rick Heath & $\mathrm{CH} 2 \mathrm{M} /$ Systems Eng & $376-3152$ \\
\hline Mike Grigsby & $\mathrm{CH} 2 \mathrm{M} / \mathrm{NS} \& \mathrm{~L}$ & $372-1907$ \\
\hline
\end{tabular}


RPP-20725 REV 2

\section{CH-TRUM Control Decision Meeting Attendance Sheet}

Meeting Subject: Dried Waste Release Accident Date: February 16, 2005

\begin{tabular}{|c|c|c|}
\hline Name & Company/Organization & Phone \\
\hline Steve Ko zlonisk1 & CITZM / NSEL & $373-1360$ \\
\hline Meruanne Kuwwnerer & 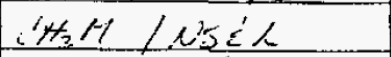 & $372-9.586$ \\
\hline waiter Scott & ORP & $376-0756$ \\
\hline Melissa Nolm & CHzm Pro Ene & $373-1098$ \\
\hline Cunt Reichmuth & cut $2 \mathrm{~m} /$ ops 8 & $376-4796$ \\
\hline Wes Bryen & $\begin{array}{l}C H 2 M / \text { Prej Engr } \\
\text { DNFSB Sitekep }\end{array}$ & $\begin{array}{l}373-9740 \\
373-0101\end{array}$ \\
\hline Robert Qyirk & DNFSB StaA & $202-694-7 k 4 y$ \\
\hline Lufer $N E / \sin$ & CHLM /TES & $673-3704$ \\
\hline Dana Bryson & ORP & $372-094 \%$ \\
\hline Rlax TEDESote it & cottem & $373-6018$ \\
\hline Ceeage Vtonicek & $C H Z M$ & $376-22 \pi$ \\
\hline LAWRENOET KRIM & cltim & $376-1061$ \\
\hline MIxE Gx,gsSy & C42m & $372-1907$ \\
\hline SHAVIN L. HAMEY & DMIM & $375-7868$ \\
\hline Hefir Vanizazariden: & =11 TM & $275.783 \%$ \\
\hline & & \\
\hline & & \\
\hline & & \\
\hline & & \\
\hline & & \\
\hline & & \\
\hline & & \\
\hline & & \\
\hline & & \\
\hline
\end{tabular}


From: Kozlowski, Stephen

Sent: Wednesday, March 02, 2005 1:59 PM

To: Scott, Walter B; Bryson, Dana C; Nelson, Roger; Janicek, George P; Kripps, Lawrence J; Bryan, Wesley E (Wes); 'shawn.hailey@dmjm.com'; Kummerer, Maryanne; Holm, Melissa J;

'Mark.VanderZanden@dmjm.com'; Tedeschi, Allan R (Rick); Sautman, Mark; Reichmuth, Curtis R; Grigsby, J M (Mike); 'sam.baker@dmjm.com'; Willingham, Grady A; Landon, Matthew R; Heath, Richard E; Jennings, Michael J; Blackford, Leonard T (TY)

Cc: Danna, Marc; Higuera, Maurice J; Goetz, Thomas G (Tom); Marchese, Andrew R

Subject: Additional Control [Decisions for the Release of Dried Waste and Waste Container Storage and Handling Accidents]

Additional control decisions are required for two new accident scenarios that were identified by Nick Barilo during preparation of RPP-21599, Prefiminary Fire Hazand's Analysis for the Contact-Handted Transuranic Mixed Waste Packaging and Temporasy Storage Facilthes (drant). The CH-TRUM PFHA is currently being prepared in support of the CH-TRUM PDSA. [Note: A Word version of this email is attached.]

The first scenario identified during preparation of the $\mathrm{CH}$-TRUM PFHA involves a new initiator to the dried waste release accident that was previously analyzed in RPP-20275, Release of Dried Radioactive Waste Materials Technical Basis Document, Rev. 1 (drant). The scenario involves a small fire that occurs in the WPS ISO contalner, DWS iso container, or exterior to those facilities, but in the vicinity of the dryer support superstructure. The fire does not progress into a large fire, but burns for suficient time to weaken and subsequently fail the dryer's steel superstructure causing the dryer to collapse. The accident results in a release of dried waste from a spill from a height of $18 \mathrm{f}(5.5 \mathrm{~m})$. This is the bounding dried release scenario with a radiological dose of $1.4 \mathrm{rem}$ offiste and "high" offsite toxicological consequences that was discussed in the control decision meetings held for that accident on January 27, 2005 and February 16, 2005 (ref. meeting minutes). Additional controls are required because the controls for that accident do not prevent or mitigate a small fire initlator to the dried waste accident.

The fire does not result in a release from the fire since, as postulated, it does not reach sufficient size or energy to breach the dryer. The large fire scenario, whlch does analyze the release due to a fire, is analyzed in RPP-24217, Technicel Rasis Report for Lange Fine Accidents InvoNing Aboveground TanksNessels, Rev. 1 (draft) in support of the CH-TRUM PDSA.

While, several potential control options were discussed internally within NS\&L and with Nick Barilo, it was agreed that only one option addresses all causes of the fire (e.g., vehicle fuel fires, range fires, hydraulic oll fire,

electrical/combustlble material fires, etc.) and is consistent with the approach taken in the tank farms DSA.

The control option recommended by NS\&L is the fire protection safety management program, a TSR-level control in the tank farms DSA (AC 5.7, Safety Management Programs). The fire protection program would recommend how to meet this requirement (e.g., fire resistant coating that meels UL classification for a 2-hr fire). The fire protection program would also specify or approve the specific coating used, and how and where it needs to be applied. If the control decision team concurs with this NS\&L recommendatlon, the following will be added to Table 3.3.2.4.7-3 (Summary of Technical Safety Requirements for the Release of Dried Waste Accident) in chapter 3 of the PDSA:

\begin{tabular}{|l|l|l|}
\hline Technical safety requirement & Safety function & Comments \\
\hline $\begin{array}{l}\text { Safety Management Programs: } \\
\text { - Fire protection }\end{array}$ & $\begin{array}{l}\text { To prevent collapse of the waste } \\
\text { dryer superstructure caused by a } \\
\text { fire, thus decreasing the frequency } \\
\text { of a release of dried waste accident }\end{array}$ & $\begin{array}{l}\text { A fire resistant coaling with a } \\
\text { 2-hour fire rating on the waste } \\
\text { dryer superstructure would satisfy } \\
\text { the safety function }\end{array}$ \\
\hline
\end{tabular}




\section{RPP-20725 REV 2}

The second scenario identlfed during preparation of the $\mathrm{CH}$-TRUM PFHA involves a varlation of the existing transportation-related storage and handling mechanical impact and vehicle fuel fire representative accident scenarios that have been previously analyzed.

The transportation-related storage and handling accidents have been updated since the previous control decision meeting (due to the recent change from SWBs to 55-gallon drums as the primary waste container, increased understanding in how operations will be conducted in and between the interim storage facility (ISF) and waste packaging system (WPS), and as a result of discussions between myself and Nick regarding these scenerios). However, the overall results as well as controls selected by the control decision team, did not change. The original scenarios that were discussed in the July 15th meeting were postulated to involve a vehicle fire engulfing SWBs staged outside the ISF, impact/drop scenarios involving SWBs stored inside the facility, and a flammable gas deflagration inside an SWB. The risk binning results (risk bin I for onsite toxicological releases) indicated that TSRlevel controls were required and the following controls were selected in the July 15th meeting:

In summary, TSR-level safety management program controls that were selected for operation of the CH-TRUM facility are as follows:

- Waste management program - to ensure compllance to waste packaging requirements (e.g., DOr, Type A compliant configuration of PSSD-compliant containers, thus reducing the frequency of transportation-related storage and handling accidents.

- Fire protection program - to prevent or mitigale fires involving CH-TRUM dried waste drums and SWBs, thus reducing the frequency or consequences of transportation-related storage and handling accidents.

As updated, the transportation-related storage and handling accident addresses large vehicle fuel fire, large vehicle mechanical impact, small vehicle impact/drop, and flammable gas deflagration accidents involving 55 -gallon drums in and near the ISF. The updated scenarlos as developed to support the CH-TRUM PDSA and as they currently exist in RPP-13978, Technical Basis for the Transpostetion-Related Handling Representative Accidents and Associated Hazandous Condtions, Rev. 2 (draft), are outlined in the following excerpt from RPP-13978, Appendix C. [excerpt omitted]

\section{"C1.3Representatlve Accidents}

The transportation accident scenarlos are described in detail in Section 2.1.1 of the main document. The $\mathrm{CH}$ TRUM representatlve accidents are summarized in this section.

The CH-TRUM transportation representative accident postulates that containers (1.e., 55-gallon drums or SWBs) filled with $\mathrm{CH}$-TRUM waste are involved in a transportation-related storage/handling accident. Without controls, this scenario is postulated to cause an uncontrolled release of radiological and toxicological dried waste. Each scenario is discussed below.

SWBs and 55-gallon steel drums are both approved packages for dried CH-TRUM waste. Each 55-gallon drum $(2.08 \mathrm{E}+02 \mathrm{~L})$ is loaded to $85 \%$ of capacity $(1.77 \mathrm{E}+02 \mathrm{~L})$ to allow room for horse-talling of plastic liners. 55-gallon drums can be packaged in SWBs (four drums per SWB) or stored on pallets (four drums per palle!). SWBs are used for packaging of non-compliant 55-gallon drums, but are expected to make up less than $1 \%$ of the total number of conlainers handled and stored in the ISF. Therefore, only 55-gallon drums are considered. 


\section{RPP-20725 REV 2}

Representative large vehicle fire accident. Hazardous conditions involving fires (e.g., vehicle fires, range fires) engulfing waste containers were postulated. The representative fire accident postulates that a transport vehicle or some other large vehicie collides into the facility passing through the wall, and impacting up to 128 55-gallon drums (or an equivalent amount of waste stored in similar containers) stored on pallels (stacked two high) inside the ISF. The impact ruptures the vehicle fuel tank spilling fuel. The presence of an ignition source is assumed and a fire occurs. The fire engulfs the waste drums resulting in a dried waste release into the atmosphere. The scenario MAR is $2.27 \mathrm{E}+04 \mathrm{~L}$.

Represented fire hazardous conditions. Several additional associated hazardous conditions that are represented and bounded by the fire representative accident were identified, some with different causes. These include, vehicle fuel/combustible material fires involving one or more (but less than 128) waste containers in CH-TRUM WPU or ISF facilities (e.g., containers stored Inside, or staged adjacent to, the ISF; containers inside the WPS ISO container that are open during drum filling operations or those that are stored/staged inside that structure, etc.). Also included, are vehicle fuel fire scenarios that occur subsequent to impact accidents during loading, unloading, and movement of drums from the WPS to the ISF, and from the ISF to the WPS in the event that drums/SWBs require repackaging.

Representative large vehicle mechanical impact accident. Hazardous conditions imvolving mechanical impact (e.g., vehicle collision, handling. drop, crane accidents) to waste containers were postulated. The mechanical impact representative accident assumes radiological and toxicological releases as the result of a transport vehicle or other large vehicle colliding Into the facility, and impacting containers stored on pallets (slacked two high) inside the ISF. Up to 128 waste drums (or an equivalent amount of waste in similar containers) are assumed to be involved in the postulated accident. Two of the 128 drums are assumed to overfilled to drum capacity $(2.08 \mathrm{E}+02 \mathrm{~L})$ due to operator error. The remaining drums are assumed to be filled to $85 \%$ of capacity $(1.77 \mathrm{E}+03 \mathrm{~L})$ in accordance with planned operations.

A damage ratio (DR) of 0.1 was assumed as established in SARAH (HNF-8739) for mechanical release trom low and high speed vehicle impact involving more than 29 drums. This value was developed based on test data. Since only PSSD-compliant containers, which are DOT Type A containers that are approved for use during cross-site transfers, are allowed to be moved from the WPS and placed in the ISF, assuming that $10 \%$ (damage ratio $=0.1$ ) of the waste in the containers will be released during the impact is conservative. The accident is assumed to cause a dried waste release into the atmosphere. The scenario MAR is $2.27 E+04 \mathrm{~L}$.

Represented impact hazardous conditions. Several additional associated hazardous condition that are represented and bounded by the representative mechanical impact accident were identlfied, some with different causes. These include impact/drop involving one or more (but less than 128) containers stored inside, or staged adjacent to, the ISF. Also included, are impact/drop scenarios during loading, unloading, and movement of drums from the WPS to the ISF, and from the ISF to the WPS in the event that drums/SWBs require repackaging.

Representatlve flammable gas accident. The flammable gas deflagration scenarlo postulates that a deflagration inside a single 55-galion occurs. The deflagration releases the contents one drum assumed to be $85 \%$ filled. The container contents are dispersed to the atmosphere. The scenerio MAR is $1.77 \mathrm{E}+02 \mathrm{~L}$.

Small vehicle dropfimpact accident. A hazardous condition involving mechanical impact or drop to one 55-gal drum during storage and handling activities (e.g., forklift or other small vehicle) in or near the ISF or during movement of a drum from the WPU to the ISF, or from the ISF to the WPS in the event that drums require repackaging, was postulated. The drum is assumed to be overfilled to $100 \%$ of capacity due to operator error. A damage ratio of 1 is assumed. The accident is assumed to result in a release of dried waste to the atmosphere. The scenario MAR is $2.08 \mathrm{E}+02 \mathrm{~L}$."

The results of the frequency determination, consequence category selection, and risk bin assignments for the representative accldents and bounding associated hazardous conditions are summarized in Table C1 of RPP-13978 (included below). 


\section{RPP-20725 REV 2}

Table C1. Summary of Results for CH-TRUM Transportation-Related Storage and Handling Accident Representative Scenarios.

\begin{tabular}{|l|l|l|l|l|l|l|l|}
\hline & & & & \multicolumn{2}{|c|}{ Risk binsequences } \\
\hline
\end{tabular}

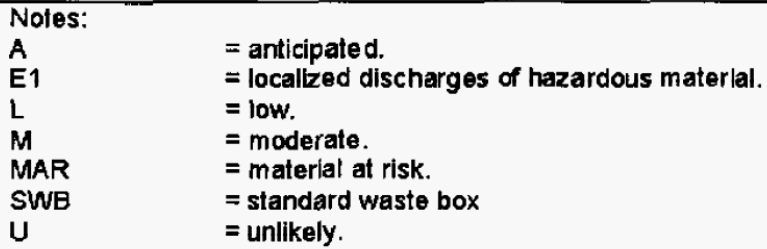

The risk binning results obtained for the updated scenarios (risk bin I for onsite toxicological releases) indicated that TSR-level controls are requlred. Since the updated scenarios were not substantially different that those presented at the July 15 th control decision meeting, the controls selected at that meeting were considered applicable to those scenarios.

The new scenario identified by Nick Barilo involves a vehicie fuel fire that causes weakening and subsequent failure of the structural supports for the ISF and collapse of the roof and supporting steel components. The result is a combined vehtcle fuel / mechanical impact scenario that engulfs 128 drums in a vehicle fuel fire the 128 drum fire scenario is unchanged), causes the roof to collapse, and impacts the remaining drums stored in the facility. The impact scenario uses the same assumptions as the $128 \mathrm{drum}$ impact scenario, except that it is assumed to involve the total number of drums (6650) of waste estimated to be retrleved from the T-Farm SSTs and processed through the $\mathrm{CH}$-TRUM facilty less the 128 drums involved in the fire scenario. The total consequences for all receptors consists of the sum of the fire and impact scenario consequences. The scenario MAR is $5.79 E+05 \mathrm{~L}$. 
RPP-20725 REV 2

\begin{tabular}{|c|c|c|c|c|c|}
\hline \multicolumn{5}{|c|}{$\begin{array}{c}\text { Estimated Consequences of Combined Vehicle Fuel Fire } \\
\text { Dnum Impact from Structural Collapse Scenarlo }\end{array}$} \\
\hline & \multicolumn{2}{|c|}{$\begin{array}{c}\text { Radiological } \\
\text { Consequences }\end{array}$} & \multicolumn{2}{|c|}{ Toxicological Sum of Fractions (SOF) } \\
\hline & Onsite & Onsite & Onsite & Onsite & Ofisite \\
\hline & (rem) & (rem) & $\begin{array}{c}\text { "High" TEEL- } \\
3\end{array}$ & $\begin{array}{c}\text { "Moderate" } \\
\text { TEEL-1 }\end{array}$ & $\begin{array}{c}\text { High" } \\
\text { TEEL-2 }\end{array}$ \\
\hline & $1.27 \mathrm{E}-02$ & $9.43 \mathrm{E}-04$ & $2.78 \mathrm{E}+00$ & $6.55 \mathrm{E}-01$ & $2.15 \mathrm{E}-01$ \\
\hline Fire & $6.15 \mathrm{E}+01$ & $6.24 \mathrm{E}-02$ & $1.74 \mathrm{E}+04$ & $4.75 \mathrm{E}-01$ & $1.64 \mathrm{E}-01$ \\
\hline Impact & 6.04 & $1.74 \mathrm{E}+04$ & $1.13 \mathrm{E}+00$ & $3.79 \mathrm{E}-01$ \\
\hline Total & $6.15 \mathrm{E}+01$ & $6.34 \mathrm{E}-02$ & & &
\end{tabular}

Tolal

8

(1)

\begin{abstract}
The preliminary results of consequence calculations performed to assist in the assignment of consequences and in risk binning (shown in the following table) indicate that onsite radiological consequences are moderate (25 - 100 rem), offsite radiological consequences are well below 1 rem, and offsite toxicological consequences are "moderate"
$(S O F>1)$. Note that the individual fire and impact scenarios separately have "low" offsite toxicological consequences, rem), offsite radiological consequences are well below 1 rem, and offsite toxicological consequences are "moderate"
$(\mathrm{SOF}>1$ ). Note that the individual fire and impact scenarios separately have "low" offsite toxicological consequences, but when summed, are "moderate."
\end{abstract} .

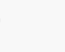

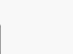

.

(1)




\section{RPP-20725 REV 2}

Updated risk binning results including those for the new representative scenarlo are shown in the following table (from RPP-13978, Appendix C).

Table C1. Summary of Results for CH-TRUM Transportation-Related Storage and Handling Accident Representative Scenarios.

\begin{tabular}{|c|c|c|c|c|c|c|c|c|}
\hline \multirow[b]{2}{*}{ Postulated accident/hazardous condition } & \multirow[b]{2}{*}{ Frequency } & \multicolumn{4}{|c|}{ Consequences } & \multicolumn{3}{|c|}{ Risk bln } \\
\hline & & 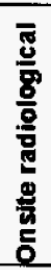 & 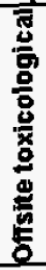 & 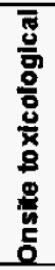 & 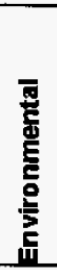 & 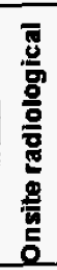 & 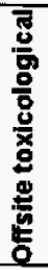 & 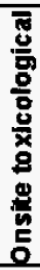 \\
\hline $\begin{array}{l}\text { Representative combined large vehicle fire / mechanical } \\
\text { Impact accldent. Release of dried waste due to combined } \\
\text { large vehicle fuel fire / mechanical impact due to fire-initiated } \\
\text { structural weakening and roof collapse impacting } 665055 \text {-gal } \\
\text { drums stored inside the ISF. MAR }=5.79 E+05 \mathrm{~L} \text {. }\end{array}$ & $\mathbf{U}$ & $\mathbf{L}$ & $M$ & $\mathrm{H}$ & E1 & III & ॥ & I \\
\hline $\begin{array}{l}\text { Representative fiammable gas accident. Release of dried } \\
\text { waste due to flammable gas accumulation and deflagration } \\
\text { inside a } 55 \text {-gallon drum. } \\
\text { MAR }=1.77 \mathrm{E}+02 \mathrm{~L} \text {. }\end{array}$ & A & $\mathbf{L}$ & $L$ & $\mathrm{H}$ & E1 & III & III & 1 \\
\hline $\begin{array}{l}\text { Release of dried waste due to large vehicle fuel fire engulfing } \\
128 \text { drums stored inside the ISF. } \\
\text { MAR }=2.27 E+04 L \text {. }\end{array}$ & $u$ & L & L & $H$ & E1 & III & III & 1 \\
\hline $\begin{array}{l}\text { Release of dried waste due to large vehicle impacting } 128 \\
\text { drums at the ISF. } \\
M A R=2.27 E+04 L \text {. }\end{array}$ & A & $\mathbf{L}$ & L & $\mathrm{H}$ & E1 & III & III & I \\
\hline $\begin{array}{l}\text { Release of dried waste due to forkllf or other small vehicle } \\
\text { impact or drop accident involving one } 55-\text { gal drum during } \\
\text { storage and handling activities in or near the ISF or during } \\
\text { movement of a drum from the WPU to the ISF. } \\
\text { MAR }=2.08 E+02 \mathrm{~L} \text {. }\end{array}$ & A & $L$ & $L$ & $H$ & E1 & III & III & 1 \\
\hline
\end{tabular}

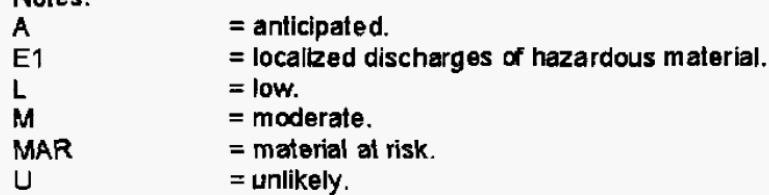

The risk binning results for the new scenario (risk bin I for onsite toxicological releases and risk bin II for offsite toxicological releases) and existing scenarios (risk bin I for onsite toxicological releases) indicate that TSR-level controls are required. As before, these scenarios are similar to those presented in the July 15, 2004 control decision meeting. The results obtained previously and upon which the control decisions were prevlously made indicate that TSR-level controls are required. 


\section{RPP-20725 REV 2}

For the combined large vehicle fire / mechanical impact scenario, as well as the remaining scenarios that were updated since the previous control decision meeting, NS\&L recommends the controls that were previously selected in the July 15, 2004 control decision meeting (i.e., AC 5.7, Safety Management Program - wasle management program and fire protection program) for operation of the $\mathrm{CH}$-TRUM facility.

If there are any questions or comments on either of these recommendations, or if anyone receiving this message feels that additional control decision meetings are necessary to finalize these results, please let me know and a meeting will be scheduled. Unless such a request is received. the recommended controls will be added to the $\mathrm{CH}-$ TRUM PDSA currently being prepared.

Thank you,

Steve Kozlowski

CH2M HILL

Nuclear Safety \& Licensing

(509) $373-1360$

Note 1: The above email discusses RPP-13978. However, subsequent to sending this email, a decision was reached by NS\&L to develop a new technical basis document (RPP-25148) for the CH-TRUM transportation accident. Also note that the title of the accident was changed in the new technical basis document from "transportation-related shipping and handling accidents" to "waste container storage and handling accidents.

Note 2: The consequence calculation and risk binning results shown in the above email underwent minor changes during NS\&L internal and peer reviews, and as a result, do not exactly match the results shown in RPP-25148. However, the results in this document (RPP-25148) are the final, technically verified results. 
RPP-20725 REV 2

\section{APPENDIX F}

SUPPORTING CALCULATIONS FOR THE DRIED WASTE RELEASE ACCIDENT AT THE CONTACT-HANDLED TRANSURANIC MIXED WASTE PACKAGING UNIT 
RPP-20725 REV 2

This page intentionally left blank.

F-ii

This page intentionally left blank.

-

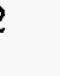

.

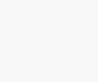




\section{APPENDIX F}

\section{SUPPORTING CALCULATIONS FOR THE DRIED WASTE RELEASE ACCIDENT AT THE CONTACT-HANDLED TRANSURANIC MIXED WASTE PACKAGING UNIT}

\section{F1.0 INTRODUCTION}

The purpose of this appendix is to provide a basis for the qualitative assessment of consequences assigned during the risk binning meetings. Consequences are calculated for the radiological and toxicological exposures resulting from a release of dry radioactive waste materials during Contact-Handled Transuranic Mixed (CH-TRUM) Waste Packaging Unit (WPU) operations.

The calculations for four basic scenarios are presented in this appendix. The scenarios involve a spill of the waste dryer contents from a height greater than $3 \mathrm{~m}$, a spill of the waste dryer contents from a height less than $3 \mathrm{~m}$, a spill of one 55-gal drum, and a failure of filtration. The bounding consequences of other dried waste release scenarios discussed in the main body of Appendix D, including the spill resulting from failure to have the drum in place and the failure caused by the fire collapsing the steel structure supporting the dryer, are the same as those for the spill from greater than $3 \mathrm{~m}$.

\section{F2.0 ASSUMPTIONS}

In the accident scenario, solids are released to drop on the ground from a failure in the waste conveyance system. The release could occur at any point between the dryer and the 55-gal drum. The result is release of the dried material to the atmosphere. It is conservatively assumed that there is no confinement and the solids move as a free-flowing powder.

Dried waste from the spill would become airborne by two mechanisms. The first is the material suspended in the airstream as the spill is occurring. The second is material that is picked up by air flowing over the heap of powder for some time following the spill (entrainment and resuspension).

The following assumptions were incorporated into the consequence analysis calculation:

1. The bounding unit liter doses (ULD) documented in RPP-5924, Radiological Source Terms for Tank Farms Safety Analysis, Table E-1, for the CH-TRUM tanks are used for estimating radiological consequences. The $11 \mathrm{CH}$-TRUM tanks are listed in Table 2-1, along with the offsite ULD values for their waste. 
Table F2-1. Unit Liter Doses for ContactHandled Transuranic Mixed Waste Tanks from RPP-5924, Rev. 4.

\begin{tabular}{|c|c|}
\hline Waste Tank & Onsite ULD (Sv/L) \\
\hline $241-\mathrm{B}-201$ & $\mathbf{1 , 2 0 0}$ \\
\hline $241-\mathrm{B}-202$ & 310 \\
\hline $241-\mathrm{B}-203$ & 310 \\
\hline $241-\mathrm{B}-204$ & 380 \\
\hline $241-\mathrm{T}-201$ & 1,200 \\
\hline $241-\mathrm{T}-202$ & 310 \\
\hline $241-\mathrm{T}-203$ & 280 \\
\hline $241-\mathrm{T}-204$ & 200 \\
\hline $241-\mathrm{T}-110$ & 110 \\
\hline $241-\mathrm{T}-111$ & 270 \\
\hline $241-\mathrm{T}-104$ & 250 \\
\hline
\end{tabular}

Note:

RPP-5924, 2003, Radiological Source Terms for

Tank Farms Safety Analysis, Rev. 4, CH2M HILL

Hanford Group, Inc., Richland, Washington.

2. It is assumed that the waste is dried to $0 \mathrm{wt} \%$ water. This is a conservative assumption since the process is designed to reduce moisture to approximately $10 \mathrm{wt} \%$. As the moisture decreases the dried material becomes less granular and begins to plug up the system. Even though "sludge" is being transferred into the dryers, the waste contains a significant amount of liquid. The waste is assumed to be dried to $0 \%$ moisture to maximize the concentration factor due to evaporation.

3. The sludge entering the dryer is assumed to contain $78 \mathrm{wt} \%$ water. This is the bounding amount of moisture found for the CH-TRUM tanks from the Best Basis Inventory (BBI) (TWINS Database queried December 1, 2004). The bounding moisture is used to calculate the maximum concentration factor due to evaporation, as follows:

Basis $=100 \mathrm{~g}$ of CH-TRUM waste solids at $78 \mathrm{wt} \%$ water

This is the equivalent to $22 \mathrm{~g}$ dry solids and $78 \mathrm{~g}$ water.

By volume:

$(78 \mathrm{~g}$ water $) /(0.998 \mathrm{~g} / \mathrm{ml}$ water $)=78 \mathrm{ml}$ water

$(22 \mathrm{~g}$ solids $) /(2.0 \mathrm{~g} / \mathrm{ml}$ solids $)=11 \mathrm{ml}$ solids

where:

$0.998 \mathrm{~g} / \mathrm{ml}$ water is the density of water at $20^{\circ} \mathrm{C}$ (Weast $1981, C R C$ Handbook of Chemistry and Physics) 


\section{RPP-20725 REV 2}

$2.0 \mathrm{~g} / \mathrm{ml}$ is the bounding density of all solids (BBI queried February 12, 2004).

Total volume before evaporation $=78 \mathrm{ml}+11 \mathrm{ml}=89 \mathrm{ml}$

Total volume after evaporation $=11 \mathrm{ml}$

$$
\text { Concentration factor }=89 \mathrm{ml} / 11 \mathrm{ml}=8.1
$$

4. The material at risk is conservatively assumed to be a full dryer batch $(6,120 \mathrm{~L})$. The material in the dryer will consist of dried CH-TRUM solids. The dryer batch size is $60 \%$ of the maximum waste dryer volume $(10,200 \mathrm{~L})$.

5. The maximum release rate of the dryer is assumed to be one batch in $10 \mathrm{~min}$. The duration of exposure for toxicological releases is $1 \mathrm{~min}$.

6. The duration of exposure to entrainment and resuspension is assumed to be $8 \mathrm{hr}$.

Additional assumptions that apply to the filtration failure analysis are:

7. The release rate due to the continuous unfiltered release following filtration failure is assumed to be proportional to the ventilation rate.

8. The design ventilation system throughputs for the nominal exhaust rate of $1,950 \mathrm{ft}^{3} / \mathrm{min}$ are given in terms of kilograms per hour of dried material for the various modules in the system are shown below. The volumetric equivalents assuming the $2 \mathrm{~g} / \mathrm{ml}$ (or $\mathrm{kg} / \mathrm{L}$ ) density for the dried material are also shown.

Table F2-2. Ventilation System Design Throughputs.

\begin{tabular}{|l|c|c|}
\hline \multirow{2}{*}{\multicolumn{1}{|c|}{ Source Stream }} & \multicolumn{2}{c|}{ Nominal Throughput } \\
\cline { 2 - 3 } & $\mathbf{k g} / \mathbf{h}$ & Dry $\mathbf{L} / \mathbf{h}$ \\
\hline Waste Receipt Tanks Ventilation & $6.52 \times 10^{-5}$ & $3.26 \times 10^{-5}$ \\
\hline Condenser Off-Gas & $4.52 \times 10^{-7}$ & $2.26 \times 10^{-7}$ \\
\hline Dryer Module Ventilation & 0 & 0 \\
\hline Packaging Module Ventilation & $4.10 \times 10^{-3}$ & $2.05 \times 10^{-3}$ \\
\hline Total & $4.10 \times 10^{-3}$ & $2.08 \times 10^{-3}$ \\
\hline
\end{tabular}

9. For purposes of this analysis a maximum exhauster flow rate of $2,000 \mathrm{ft}^{3} / \mathrm{min}$ was assumed and the throughputs were increased proportionally.

10. The maximum loading on each HEPA filter is assumed to be $1 \mathrm{~L}$ of solids based on filter plugging (i.e. high $\triangle \mathrm{P}$ and low flow rate). Studies of $2 \mathrm{ft}$ by $2 \mathrm{ft}$ standard HEPA filters under very high loading conditions (Response of HEPA Filters to Simulated Accident Conditions [Gregory et al. 1982]) showed that plugging (defined to be a $50 \%$ flow rate reduction) occurred at loadings of less than $500 \mathrm{~g}$ (corresponding to about 
$0.5 \mathrm{~L}$ ) of dry polystyrene-latex aerosol. Using a stearic acid aerosol, plugging occurred at a loading of $550 \mathrm{~g}$ corresponding to $0.56 \mathrm{~L}$ of dry solids. The $50 \%$ flow reduction corresponded to a filter $\Delta \mathrm{P}$ of about $12 \mathrm{in.} \mathrm{w.g.} \mathrm{A} \mathrm{filter} \Delta \mathrm{P}$ of $10 \mathrm{in}$. w.g. was obtained at a lower loading of $400 \mathrm{~g}(0.41 \mathrm{~L})$ of dry solids. Manufacturers generally do not guarantee the integrity of their filters above $10 \mathrm{in.} \mathrm{w.g.} \mathrm{For} \mathrm{this} \mathrm{reason,} \mathrm{operating}$ HEPA filters are never allowed to approach a $\Delta \mathrm{P}$ of $10 \mathrm{in.}$ w.g., but are limited to much less (i.e., 5 to 6 in. w.g.). The assumed $1 \mathrm{~L}$ filter loading is therefore considered to be highly conservative.

11. The total load of waste within the filter system (two prefilters, four HEPA filters, and one duct) subject to release is therefore assumed to be $5.2 \mathrm{HEPA}$ loads or $5.2 \mathrm{~L}$ of dried solids equivalent to $42.2 \mathrm{~L}$ of reference wet sludge.

\section{F3.0 METHODOLOGY}

\section{F3.1 APPROACH TO ANALYSIS}

Radiological dose exposure consequences are calculated consistent with the methodology documented in RPP-13482, Atmospheric Dispersion Coefficients and Radiological and Toxicological Exposure Methodology for Use in Tank Farms. The onsite dose (Equation F-1) is given by:

$$
\text { Dose }=(Q, \text { released })\left(\chi / Q^{\prime}\right)(B R)(U L D, \text { onsite })
$$

where:

$$
\begin{array}{ll}
\text { Dose } & =\text { inhalation dose to the onsite receptor, } \mathrm{Sv} \\
Q, \text { released } & =\text { liters of respirable material released to the environment, } \mathrm{L} \\
\chi / Q^{\prime} & =\text { atmospheric dispersion coefficient, } \mathrm{s} / \mathrm{m}^{3} \\
B R & =\text { breathing rate, } \mathrm{m}^{3} / \mathrm{s} \\
U L D, \text { onsite } & =\text { dose per unit liter of material inhaled as aerosols, } \mathrm{Sv} / \mathrm{L} .
\end{array}
$$

The toxicological consequences were calculated per the methodology established in RPP-13482 for toxicological releases. Toxicological consequences are calculated either with a puff release model or a continuous release model depending on the duration of the release. The puff release model is used for onsite releases with durations $<3.7 \mathrm{sec}$, and for offsite releases with durations $<439 \mathrm{sec}$ (RPP-13482). The events considered in this appendix are modeled as continuous releases. For a continuous release, the toxicological consequence (Equation F-2) is given by:

$$
\text { Consequence }=(Q / t)\left(\chi / Q^{\prime}\right)(\text { SOF Multiplier })
$$




\section{RPP-20725 REV 2}

where:

$$
\begin{array}{ll}
\text { Consequence } & =\text { final sum of fractions value, unitless } \\
Q & =\text { release to the environment, } \mathrm{m}^{3} \\
t & =\text { release time, sec } \\
\chi / Q^{\prime} & =\text { atmospheric dispersion coefficient, } \mathrm{s} / \mathrm{m}^{3} \\
\text { SOF Multiplier } & =\text { sum of fractions multiplier, unitless. }
\end{array}
$$

Determining the quantity of respirable material released to the environment requires knowledge of the volume that is affected and is provided in Equation F-3:

$$
\text { Source Term }(Q)=(M A R)(D R)(A R F)(R F)
$$

where:

$$
\begin{array}{ll}
Q & =\text { source term, } \mathrm{L} \\
M A R & =\text { material at risk, } \mathrm{L} \\
D R & =\text { damage ratio }=1^{*} \\
A R F & =\text { airborne release fraction } \\
R F & =\text { respirable fraction (not applicable to toxicological consequences). }
\end{array}
$$

*Note: The damage ratio is not used for the scenarios in this appendix so a value of 1 is applied.

\section{F3.2 VERIFICATION AND VALIDATION}

No computer codes have been used to develop the accident analysis results documented in this appendix; therefore, software verification and validation is not required or provided. 


\section{RPP-20725 REV 2}

\section{F4.0 INPUT DATA}

The input data used are as follows:

1. The onsite ULD that bounds the tanks to be processed by the WPU is taken from RPP-5924:

$\begin{array}{lccc}\text { Waste Type } & \underline{\text { ULD }(\mathrm{Sv} / \mathrm{L})} & \underline{\text { Basis Tank }} & \text { Waste Type } \\ \text { SST Solid } & 1200 & 241-\mathrm{B}-201 & \text { Sludge }\end{array}$

2. Sum of fractions (SOF) multipliers that bound the tanks to be processed by the WPU are taken from RPP-8369, Chemical Source Terms for Tank Farms Safety Analyses:

$\begin{array}{ccccccc}\text { Waste Type } & \text { TEEL-1 } & \text { Basis Tank } & \text { TEEL-2 } & \text { Basis Tank } & \text { TEEL-3 } & \text { Basis Tank } \\ \text { SST Solid } & 1.71 \times 10^{9} & \text { 241-B-203 } & 5.60 \times 10^{8} & \text { 241-B-203 } & 3.39 \times 10^{8} & \text { 241-T-202 }\end{array}$

3. The breathing rate is $3.33 \times 10^{-4} \mathrm{~m}^{3} / \mathrm{sec}$ (RPP-5924).

4. The bounding airborne release fraction (ARF) for spills of cohesionless powders from heights greater than $3 \mathrm{~m}$.

$$
A R F_{B}=\frac{2 \times 0.1064 \times M_{0}^{0.125} \times H^{2.37}}{\rho_{B P}{ }^{1.02}}
$$

where:

$$
\begin{array}{ll}
\mathrm{ARF}_{\mathrm{B}} & =\text { bounding airborne release fraction } \\
\mathrm{M}_{0} & =\text { mass of powder spilled, } \mathrm{kg} \\
\mathrm{H} & =\text { spill height, } \mathrm{m} \\
\rho_{\mathrm{BP}} & =\text { bulk density of powder, } \mathrm{kg} / \mathrm{m}^{3} .
\end{array}
$$

This ARF is to be compared to the ARF $x$ RF (respirable fraction) combination of $2 \times 10^{-3} \times 0.3\left(6 \times 10^{-4}\right)$ given in DOE-HDBK-3010-94, Airborne Release

Fractions/Rates and Respirable Fractions for Nonreactor Nuclear Facilities, for spills of cohesionless powders from heights of less than $3 \mathrm{~m}$. The greater of the two values should be used.

The DOE handbook does not indicate a RF value to be used with the ARF calculated above. Therefore, it is assumed that the RF for this case is 1.0 , because the comparison the handbook asks for is against an ARF $x$ RF combination.

5. The ARF is $2 \times 10^{-3}$ for free-fall spill of cohesionless powders with a fall distance of less than $3 \mathrm{~m}$ (DOE-HDBK-3010-94). 


\section{RPP-20725 REV 2}

6. The RF (used only for calculating radiological consequences) is 0.3 for a free-fall spill of a cohesionless powder with a fall distance of less than $3 \mathrm{~m}$ (DOE-HDBK-3010-94).

7. The airborne release rate (ARR) for aerodynamic entrainment and resuspension of a homogeneous bed of powder exposed to ambient conditions is $4 \times 10^{-5} \mathrm{hr}^{-1}$ (DOE-HDBK-3010-94).

8. The RF (used only for radiological consequences) is 1.0 for aerodynamic entrainment and resuspension of a homogeneous bed of powder exposed to ambient conditions (DOE-HDBK-3010-94).

9. The integrated atmospheric dispersion coefficients for the initial spill are $3.28 \times 10^{-2} \mathrm{~s} / \mathrm{m}^{3}$ and $2.22 \times 10^{-5} \mathrm{~s} / \mathrm{m}^{3}$ for the onsite and offsite receptors, respectively. These are the 1-hr $95^{\text {th }}$ percentile overall $\chi / Q$ 's provided in RPP-13482, Tables 2-4 and 2-5. The appropriate $\chi / \mathrm{Q}^{\prime}$ s for use with the resuspension and entrainment portion of the release are the $8-\mathrm{hr}$ $95^{\text {th }}$ percentile overall $\chi / \mathrm{Q}$ 's, $5.58 \times 10^{-3} \mathrm{~s} / \mathrm{m}^{3}$ for the onsite receptor, and $7.90 \times 10^{-6} \mathrm{~s} / \mathrm{m}^{3}$ for the offsite receptor. The assumptions, input parameters, and derivation of these values are documented in RPP-13482.

\section{F5.0 CALCULATIONS}

\section{F5.1 DRIED WASTE SPILL FROM GREATER THAN 3 M}

\section{F5.1.1 Calculation of Airborne Release Fraction}

As stated in Section B4.0, Item 4, the bounding ARF for a spill of a cohesionless powder from a height greater than $3 \mathrm{~m}$ is a function of the mass spilled and the spill height. A breach of the dryer could occur at any height above its bottom. However, as the breach gets higher, there will be less dried waste above the breach available to leak out. A parametric calculation was performed to assess the height at which the maximum airborne release would be expected.

The waste dryer is a horizontal cylinder. To calculate the volume above a breach as a function of the height of the breach above the dryer bottom, the cross-sectional area of the waste dryer that is above the breach is multiplied by the length, $5.1 \mathrm{~m}$, of the waste dryer.

When the breach is above the middle of the tank, the formula for the cross-sectional area above it is the formula for a circular segment:

$$
A=r^{2} \cos ^{-1}\left(\frac{r-x}{r}\right)-(r-x) \sqrt{2 r x-x^{2}}
$$

For: $\mathrm{x} \leq \mathrm{r}$ 


\section{RPP-20725 REV 2}

When the breach is below the midpoint of the tank, the formula for the waste above the breach is:

$$
A=\pi r^{2}-\left[r^{2} \cos ^{-1}\left(\frac{r-x^{\prime}}{r}\right)-\left(r-x^{\prime}\right) \sqrt{2 r x^{\prime}-x^{\prime 2}}\right]
$$

and

$$
x^{\prime}=2 r-x
$$

For: $\mathrm{x}>\mathrm{r}$

where:

$\mathrm{r}=$ the radius of the dryer cross section, $0.8 \mathrm{~m}$

$\mathrm{x}=$ the vertical distance from the dryer top to the plane of the breach, $\mathrm{m}$

$x^{\prime}=$ the vertical distance from the dryer bottom to the plane of the breach, $m$.

The fill level for the dryer when it is $60 \%$ full $(6,120 \mathrm{~L})$ is $0.93 \mathrm{~m}$ above the bottom of the tank. Therefore, a breach above that level will not result in a release of dried material. Table F5-1 shows the results of calculating the volume and mass of waste above a series of assumed breach heights, the ARF, and the resulting volume of airborne dried waste released.

Table F5-1. Evaluation of Maximum Airborne Release as a

\begin{tabular}{|c|c|c|c|c|}
\hline $\begin{array}{c}\text { Spill } \\
\text { Height } \\
\text { (H in m) }\end{array}$ & $\begin{array}{c}\text { Material at Risk } \\
\text { (Spill Volume in L) }\end{array}$ & $\begin{array}{c}\text { Material at Risk } \\
\qquad\left(M_{0} \text { in } \mathrm{kg}\right)\end{array}$ & $\mathbf{A R F _ { B }}$ & $\begin{array}{c}\text { Airborne Release } \\
\text { (L) }\end{array}$ \\
\hline 6.426 & 0 & 0 & 0 & 0 \\
\hline 6.4 & 209 & 334 & 0.019 & 4.00 \\
\hline 6.3 & 1,018 & 1,630 & 0.023 & 23 \\
\hline 6.2 & 1,828 & 2,925 & 0.0233 & 43 \\
\hline 6.1 & 2,625 & 4,200 & 0.024 & 62 \\
\hline 6 & 3,395 & 5,432 & 0.023 & 80 \\
\hline 5.9 & 4,124 & 6,599 & 0.023 & 95 \\
\hline 5.8 & 4,795 & 7,671 & 0.023 & 108 \\
\hline 5.7 & 5,383 & 8,612 & 0.022 & 119 \\
\hline 5.6 & 5,853 & 9,365 & 0.021 & 125 \\
\hline 5.5 & 6,118 & 9,790 & 0.020 & 126 \\
\hline
\end{tabular}
Function of Powder Spill Height.

Notes:

The bottom of the CH-TRUM dryer is at $5.5 \mathrm{~m}$ above grade; the fill height of $6,120 \mathrm{~L}$ is at $6.4 \mathrm{~m}$ above grade.

Assumes a perfect horizontal cylinder dryer shape and dried waste bulk density, $\rho_{\mathrm{BP}}$, of $1.6 \mathrm{~kg} / \mathrm{L}$ or $1,600 \mathrm{~kg} / \mathrm{m}^{3}$.
ARF $\quad=$ airborne release fraction.
$\mathrm{CH}-\mathrm{TRUM}=$ Contact-Handled Transuranic Mixed (Waste). 


\section{RPP-20725 REV 2}

As shown in Table F5-1, the maximum airborne release would be $126 \mathrm{~L}$ of dried waste spilled from a breach at the bottom of the waste dryer.

\section{F5.1.2 Onsite Radiological Consequences}

As stated in Section F3.1, the onsite dose for a free-fall spill of cohesionless powder is found using the methodology in RPP-13482. The onsite dose is given by Equation F-1:

$$
D_{\text {spill }}=(Q, \text { released })\left(\chi / Q^{\prime}\right)(B R)(U L D)
$$

where:

$$
\begin{aligned}
Q, \text { released } & =\text { liters of respirable material released to the environment }(\mathrm{L}) \\
& =M A R \times D R \times A R F \times R F \\
& =(6,120 \mathrm{~L})(1)(0.020)(1.0) \\
& =126 \mathrm{~L} \\
& =\text { onsite atmospheric dispersion coefficient } \\
& =3.28 \times 10^{-2} \mathrm{~s} / \mathrm{m}^{3} \\
& =\text { Breathing rate } \\
& =3.33 \times 10^{-4} \mathrm{~m}^{3} / \mathrm{s} \\
B R & =(\text { onsite } \mathrm{ULD} \text { before drying) (concentration factor) } \\
U L D \quad & (1,200 \mathrm{~Sv} / \mathrm{L})(8.1) \\
& =9,720 \mathrm{~Sv} / \mathrm{L} .
\end{aligned}
$$

The onsite dose for free-fall spills is:

$$
D_{\text {spill }}=(126 \mathrm{~L})\left(3.28 \times 10^{-2} \mathrm{~s} / \mathrm{m}^{3}\right)\left(3.33 \times 10^{-4} \mathrm{~m}^{3} / \mathrm{s}\right)(9,720 \mathrm{~Sv} / \mathrm{L})=13 \mathrm{~Sv}
$$

The onsite dose for entrainment and resuspension can be found similarly using the ARR:

$$
D_{\text {entrainment }}=(Q, \text { released })\left(\chi / Q^{\prime}\right)(B R)(U L D)
$$

where:

$$
\begin{aligned}
Q, \text { released } & =\text { liters of respirable material released to the environment }(\mathrm{L}) \\
& =M A R \times D R \times A R R \times R F \times \text { release time } \\
& =(6,120 \mathrm{~L})(1)\left(4 \times 10^{-5} \mathrm{~h}^{-1}\right)(1.0)(8 \mathrm{~h}) \\
& =1.96 \mathrm{~L} \\
& =\text { onsite atmospheric dispersion coefficient } \\
& =5.58 \times 10^{-3} \mathrm{~s}^{3} \\
& =\text { Breathing rate } \\
& =3.33 \times 10^{-4} \mathrm{~m}^{3} / \mathrm{s} \\
B R & =(\text { onsite } \mathrm{ULD} \mathrm{before} \mathrm{drying}) \text { (concentration factor) } \\
U L D \quad & (1,200 \mathrm{~Sv} / \mathrm{L})(8.1) \\
& =9,720 \mathrm{~Sv} / \mathrm{L} .
\end{aligned}
$$




\section{RPP-20725 REV 2}

The onsite dose due to entrainment is:

$$
D_{\text {entrainment }}=(1.96 \mathrm{~L})\left(5.58 \times 10^{-3} \mathrm{~s} / \mathrm{m}^{3}\right)\left(3.33 \times 10^{-4} \mathrm{~m}^{3} / \mathrm{s}\right)(9,720 \mathrm{~Sv} / \mathrm{L})=0.035 \mathrm{~Sv}
$$

The total onsite dose is the sum of the dose due to the free-fall spill and the entrainment from the unconfined powder:

$$
\begin{gathered}
\text { Dose }=D_{\text {spill }}+D_{\text {entrainment }} \\
\text { Dose }=13 \mathrm{~Sv}+0.035 \mathrm{~Sv}=13=1,300 \mathrm{rem}
\end{gathered}
$$

\section{F5.1.3 Toxicological Consequences}

\section{F5.1.3.1 Onsite Toxicological Consequences}

As stated in Section F3.1 the toxicological consequences for a free-fall spill of cohesionless powder are calculated per the methodology established in RPP-13482. The onsite toxicological consequences are determined by Equation F-2:

$$
\text { Consequence }_{\text {spill }}=(Q / t)\left(\chi / Q^{\prime}\right)(\text { SOF Multiplier })
$$

where:

$$
\begin{aligned}
\text { Consequence } & =\text { final sum of fractions value, unitless } \\
Q / t & =\text { rate of release to the environment }\left(\mathrm{m}^{3} / \mathrm{s}\right) \\
& =(M A R \times D R \times A R F) / t \\
& =(6,120 \mathrm{~L})(1)(0.020) / 600 \mathrm{~s} \\
& =0.20 \mathrm{~L} / \mathrm{s}\left(1 \mathrm{~m}^{3} / 1 \times 10^{3} \mathrm{~L}\right)=2.0 \times 10^{-4} \mathrm{~m}^{3} / \mathrm{s} \\
& =\text { onsite atmospheric dispersion coefficient } \\
& =3.28 \times 10^{-2} \mathrm{~s} / \mathrm{m}^{3} \\
\chi / Q^{\prime} & \text { sum-of-fractions multiplier, unitless } \\
\text { SOF Multiplier } & =(\text { TEEL-2 SOF })=5.60 \times 10^{8} \\
& =(\text { TEEL-3 SOF })=3.39 \times 10^{8} .
\end{aligned}
$$

The onsite moderate toxicological consequence for a spill (based on TEEL-2) is:

$$
\text { Consequence }=\left(2.0 \times 10^{-4} \mathrm{~m}^{3} / \mathrm{s}\right)\left(3.28 \times 10^{-2} \mathrm{~s} / \mathrm{m}^{3}\right)\left(5.60 \times 10^{8}\right)=3,800
$$

The onsite high toxicological consequence for a spill (based on TEEL-3) is:

$$
\text { Consequence }=\left(2.0 \times 10^{-4} \mathrm{~m}^{3} / \mathrm{s}\right)\left(3.28 \times 10^{-2} \mathrm{~s} / \mathrm{m}^{3}\right)\left(3.39 \times 10^{8}\right)=2,300
$$

The onsite consequence for entrainment and resuspension can be found similarly using the ARR:

$$
\text { Consequence }_{\text {entrainment }}=(Q / t)\left(\chi / Q^{\prime}\right)(\text { SOF Multiplier })
$$




\section{RPP-20725 REV 2}

where:

$$
\begin{aligned}
& \text { Consequence }=\text { final sum of fractions value, unitless } \\
& Q / t \quad=\text { rate of release to the environment }\left(\mathrm{m}^{3} / \mathrm{s}\right) \\
& =M A R \times D R \times A R R \times \text { conversion factor } \\
& =(6,120 \mathrm{~L})(1)\left(4 \times 10^{-5} \mathrm{hr}^{-1}\right)(1 \mathrm{hr} / 3,600 \mathrm{~s}) \\
& =6.8 \times 10^{-5} \mathrm{~L} / \mathrm{s}=6.8 \times 10^{-8} \mathrm{~m}^{3} / \mathrm{s} \\
& \chi / Q^{\prime} \quad=\text { onsite atmospheric dispersion coefficient } \\
& =3.28 \times 10^{-2} \mathrm{~s} / \mathrm{m}^{3} \\
& \text { SOF Multiplier }=\text { sum-of-fractions multiplier, unitless } \\
& =(\text { TEEL-2 SOF })=5.60 \times 10^{8} \\
& =(\text { TEEL-3 SOF })=3.39 \times 10^{8} \text {. }
\end{aligned}
$$

The onsite moderate toxicological consequence for entrainment (based on TEEL-2) is:

$$
\text { Consequence }=\left(6.8 \times 10^{-8} \mathrm{~m}^{3} / \mathrm{s}\right)\left(3.28 \times 10^{-2} \mathrm{~s} / \mathrm{m}^{3}\right)\left(5.60 \times 10^{8}\right)=1.25
$$

The onsite high toxicological consequence for entrainment (based on TEEL-3) is:

$$
\text { Consequence }=\left(6.8 \times 10^{-8} \mathrm{~m}^{3} / \mathrm{s}\right)\left(3.28 \times 10^{-2} \mathrm{~s} / \mathrm{m}^{3}\right)\left(3.39 \times 10^{8}\right)=0.076
$$

The overall onsite toxicological consequences can be found by summing the contribution of the free-fall spill with the subsequent entrainment and resuspension.

The total onsite moderate toxicological consequence (based on TEEL-2) is:

$$
\text { Consequence }=3,800+1.25=3,800
$$

The total onsite high toxicological consequence (based on TEEL-3) is:

$$
\text { Consequence }=2,300+0.076=2,300 \text {. }
$$

\section{F5.1.3.2 Offsite Toxicological Consequences}

The offsite toxicological consequences are determined similarly:

$$
\text { Consequence }=(Q / t)\left(\chi / Q^{\prime}\right)(S O F \text { Multiplier })
$$

where:

$$
\begin{aligned}
\text { Consequence } & =\text { final sum of fractions value, unitless } \\
Q / t & =\text { rate of release to the environment }\left(\mathrm{m}^{3} / \mathrm{s}\right) \\
& =(M A R \times D R \times A R F) / t \\
& =(6,120 \mathrm{~L})(1)(0.020) / 600 \mathrm{~s} \\
& =0.20 \mathrm{~L} / \mathrm{s}=2.0 \times 10^{-4} \mathrm{~m}^{3} / \mathrm{s} \\
& =\text { offsite atmospheric dispersion coefficient } \\
& =2.22 \times 10^{-5} \mathrm{~s}^{3}
\end{aligned}
$$




\section{RPP-20725 REV 2}

$$
\begin{aligned}
\text { SOF Multiplier } & =\text { sum-of-fractions multiplier, unitless } \\
& =(\text { TEEL-1 SOF })=1.71 \times 10^{9} \\
& =(\text { TEEL-2 SOF })=5.60 \times 10^{8} .
\end{aligned}
$$

The offsite moderate toxicological consequence for a spill (based on TEEL-1) is:

$$
\text { Consequence }=\left(2.0 \times 10^{-4} \mathrm{~m}^{3} / \mathrm{s}\right)\left(2.22 \times 10^{-5} \mathrm{~s} / \mathrm{m}^{3}\right)\left(1.71 \times 10^{9}\right)=7.9
$$

The offsite high toxicological consequence for a spill (based on TEEL-2) is:

$$
\text { Consequence }=\left(2.0 \times 10^{-4} \mathrm{~m}^{3} / \mathrm{s}\right)\left(2.22 \times 10^{-5} \mathrm{~s} / \mathrm{m}^{3}\right)\left(5.60 \times 10^{8}\right)=2.6
$$

The offsite consequence for entrainment and resuspension can be found similarly using the ARR:

$$
\text { Consequence }_{\text {entrainment }}=(Q / t)\left(\chi / Q^{\prime}\right)(\text { SOF Multiplier })
$$

where:

$$
\begin{aligned}
\text { Consequence } & =\text { final sum of fractions value, unitless } \\
& =\text { release to the environment }\left(\mathrm{m}^{3} / \mathrm{s}\right) \\
& =\text { MAR } \times \text { DR } \times \text { ARR } \times \text { conversion factor } \\
& =(6,120 \mathrm{~L})(1)\left(4 \times 10^{-5} \mathrm{hr}^{-1}\right)(1 \mathrm{hr} / 3,600 \mathrm{~s}) \\
& =6.8 \times 10^{-5} \mathrm{~L} / \mathrm{s}=6.8 \times 10^{-8} \mathrm{~m}^{3} / \mathrm{s} \\
& =\text { offsite atmospheric dispersion coefficient } \\
& =2.22 \times 10^{-5} \mathrm{~s}^{3} \mathrm{~m}^{3} \\
\chi^{\prime} Q^{\prime} & \\
\text { SOF Multiplier } & =\text { sum-of-fractions multiplier, unitless } \\
& =(\text { TEEL-1 SOF })=1.71 \times 10^{9} \\
& =(\text { TEEL-2 SOF })=5.60 \times 10^{8} .
\end{aligned}
$$

The offsite moderate toxicological consequence for entrainment (based on TEEL-1) is:

$$
\text { Consequence }=\left(6.8 \times 10^{-8} \mathrm{~m}^{3} / \mathrm{s}\right)\left(2.22 \times 10^{-5} \mathrm{~s} / \mathrm{m}^{3}\right)\left(1.71 \times 10^{9}\right)=2.6 \times 10^{-3}
$$

The offsite high toxicological consequence for entrainment (based on TEEL-2) is:

$$
\text { Consequence }=\left(6.8 \times 10^{-8} \mathrm{~m}^{3} / \mathrm{s}\right)\left(2.22 \times 10^{-5} \mathrm{~s} / \mathrm{m}^{3}\right)\left(5.60 \times 10^{8}\right)=8.4 \times 10^{-4}
$$

The overall offsite toxicological consequences can be found by summing the contribution of the free-fall spill with the subsequent entrainment and resuspension.

The total offsite moderate toxicological consequence (based on TEEL-1) is:

$$
\text { Consequence }=7.9+2.6 \times 10^{-3}=7.9
$$

The total offsite high toxicological consequence (based on TEEL-2) is:

$$
\text { Consequence }=2.6+8.4 \times 10^{-4}=2.6
$$


The consequences are also presented in Section F6.0, Tables F6-1 and F6-2.

\section{F5.2 SPILL FROM LESS THAN 3 M}

\section{F5.2.1 Onsite Radiological Consequences}

As stated in Section F3.1, the onsite dose for a free-fall spill of cohesionless powder is found using the methodology in RPP-13482. The onsite dose is given by Equation F-1:

$$
D_{\text {spill }}=(Q, \text { released })\left(\chi / Q^{\prime}\right)(B R)(U L D)
$$

where:

$$
\begin{aligned}
Q, \text { released } & =\text { liters of respirable material released to the environment (L) } \\
& =M A R \times D R \times A R F \times R F \\
& =(6,120 \mathrm{~L})(1)\left(2 \times 10^{-3}\right)(0.3) \\
& =3.7 \mathrm{~L} \\
& =\text { onsite atmospheric dispersion coefficient } \\
& =3.28 \times 10^{-2} \mathrm{~s} / \mathrm{m}^{3} \\
& =\text { breathing rate } \\
& =3.33 \times 10^{-4} \mathrm{~m}^{3} / \mathrm{s} \\
B R \quad & =(\text { onsite } \mathrm{ULD} \text { before drying) (concentration factor) } \\
U L D \quad & (1,200 \mathrm{~Sv} / \mathrm{L})(8.1) \\
& =9,720 \mathrm{~Sv} / \mathrm{L} .
\end{aligned}
$$

The onsite dose for free-fall spills is:

$$
D_{\text {spill }}=(3.7 \mathrm{~L})\left(3.28 \times 10^{-2} \mathrm{~s} / \mathrm{m}^{3}\right)\left(3.33 \times 10^{-4} \mathrm{~m}^{3} / \mathrm{s}\right)(9,720 \mathrm{~Sv} / \mathrm{L})=0.39 \mathrm{~Sv}
$$

The onsite dose for entrainment and resuspension is $0.035 \mathrm{~Sv}$, as calculated in Section F5.1.2.

The total onsite dose is the sum of the dose due to the free-fall spill and the entrainment from the unconfined powder:

$$
\begin{gathered}
\text { Dose }=D_{\text {spill }}+D_{\text {entrainment }} \\
\text { Dose }=0.39 \mathrm{~Sv}+0.035 \mathrm{~Sv}=0.42=42 \mathrm{rem}
\end{gathered}
$$

\section{F5.2.2 Toxicological Consequences}

\section{F5.2.2.1 Onsite Toxicological Consequences}

As stated in Section 3.1 the toxicological consequences for a free-fall spill of cohesionless powder are calculated per the methodology established in RPP-13482. The onsite toxicological consequences are determined by Equation F-2:

$$
\text { Consequence }_{\text {spill }}=(Q / t)\left(\chi / Q^{\prime}\right)(S O F \text { Multiplier })
$$




\section{RPP-20725 REV 2}

where:

$$
\begin{aligned}
\text { Consequence } & =\text { final sum of fractions value, unitless } \\
Q / t & =\text { rate of release to the environment }\left(\mathrm{m}^{3} / \mathrm{s}\right) \\
& =(M A R \times D R \times A R F) / t \\
& =(6,120 \mathrm{~L})(1)\left(2 \times 10^{-3}\right) / 600 \mathrm{~s} \\
& =2.0 \times 10^{-2} \mathrm{~L} / \mathrm{s}=2.0 \times 10^{-5} \mathrm{~m}^{3} / \mathrm{s} \\
& =\text { onsite atmospheric dispersion coefficient } \\
& =3.28 \times 10^{-2} \mathrm{~s} / \mathrm{m}^{3} \\
\chi / Q^{\prime} & \\
\text { SOF Multiplier } & =\text { sum-of-fractions multiplier, unitless } \\
& =(\text { TEEL-2 SOF })=5.60 \times 10^{8} \\
& =(\text { TEEL-3 SOF })=3.39 \times 10^{8} .
\end{aligned}
$$

The onsite moderate toxicological consequence for a spill (based on TEEL-2) is:

$$
\text { Consequence }=\left(2.0 \times 10^{-5} \mathrm{~m}^{3} / \mathrm{s}\right)\left(3.28 \times 10^{-2} \mathrm{~s} / \mathrm{m}^{3}\right)\left(5.60 \times 10^{8}\right)=380
$$

The onsite high toxicological consequence for a spill (based on TEEL-3) is:

$$
\text { Consequence }=\left(2.0 \times 10^{-5} \mathrm{~m}^{3} / \mathrm{s}\right)\left(3.28 \times 10^{-2} \mathrm{~s} / \mathrm{m}^{3}\right)\left(3.39 \times 10^{8}\right)=230
$$

The onsite toxicological consequence for entrainment and resuspension was calculated in Section F5 1.3.1. The onsite moderate toxicological consequence for entrainment (based on TEEL-2) is 1.25. The onsite high toxicological consequence for entrainment (based on TEEL-3) is 0.076 .

The overall onsite toxicological consequences can be found by summing the contribution of the free-fall spill with the subsequent entrainment and resuspension.

The total onsite moderate toxicological consequence (based on TEEL-2) is:

$$
\text { Consequence }=380+1.25=380
$$

The total onsite high toxicological consequence (based on TEEL-3) is:

$$
\text { Consequence }=230+0.076=230
$$

\section{F5.2.2.2 Offsite Toxicological Consequences}

The offsite toxicological consequences are determined similarly:

$$
\text { Consequence }=\left(Q^{\prime} t\right)\left(\chi / Q^{\prime}\right)(\text { SOF Multiplier })
$$


where:

$$
\begin{aligned}
\text { Consequence } & =\text { final sum of fractions value, unitless } \\
Q / t & =\text { rate of release to the environment }\left(\mathrm{m}^{3} / \mathrm{s}\right) \\
& =(\text { MAR } \times \text { DR } \times A R F) / t \\
& =(6,120 \mathrm{~L})(1)\left(2 \times 10^{-3}\right) / 600 \mathrm{~s} \\
& =2.0 \times 10^{-2} \mathrm{~L} / \mathrm{s}=2.0 \times 10^{-5} \mathrm{~m}^{3} / \mathrm{s} \\
& =\text { offsite atmospheric dispersion coefficient } \\
& =2.22 \times 10^{-5} \mathrm{~s}^{3} \\
\chi / \mathrm{m}^{\prime} & \\
\text { SOF Multiplier } & =\text { sum-of-fractions multiplier, unitless } \\
& =(\text { TEEL-1 SOF })=1.71 \times 10^{9} \\
& =(\text { TEEL-2 SOF })=5.60 \times 10^{8} .
\end{aligned}
$$

The offsite moderate toxicological consequence for a spill (based on TEEL-1) is:

$$
\text { Consequence }=\left(2.0 \times 10^{-5} \mathrm{~m}^{3} / \mathrm{s}\right)\left(2.22 \times 10^{-5} \mathrm{~s} / \mathrm{m}^{3}\right)\left(1.71 \times 10^{9}\right)=0.77
$$

The offsite high toxicological consequence for a spill (based on TEEL-2) is:

$$
\text { Consequence }=\left(2.0 \times 10^{-5} \mathrm{~m}^{3} / \mathrm{s}\right)\left(2.22 \times 10^{-5} \mathrm{~s} / \mathrm{m}^{3}\right)\left(5.60 \times 10^{8}\right)=0.25
$$

The offsite consequence for entrainment and resuspension were calculated in Section F5.1.3.2. The offsite moderate toxicological consequence for entrainment (based on TEEL-1) is $2.6 \times 10^{-3}$. The offsite high toxicological consequence for entrainment (based on TEEL-2) is $8.4 \times 10^{-4}$.

The overall offsite toxicological consequences can be found by summing the contribution of the free-fall spill with the subsequent entrainment and resuspension.

The total offsite moderate toxicological consequence (based on TEEL-1) is:

$$
\text { Consequence }=0.77+2.6 \times 10^{-3}=0.78
$$

The total offsite high toxicological consequence (based on TEEL-2) is:

$$
\text { Consequence }=0.25+8.4 \times 10^{-4}=0.26
$$

\section{F5.3 SPILL OF A SINGLE DRUM}

\section{F5.3.1 Onsite Radiological Consequences}

As stated in Section F3.1, the onsite dose for a free-fall spill of cohesionless powder is found using the methodology in RPP-13482. The onsite dose is given by Equation F-1:

$$
D_{\text {spill }}=(Q, \text { released })\left(\chi / Q^{\prime}\right)(B R)(U L D)
$$




\section{RPP-20725 REV 2}

where:

$Q$, released $=$ liters of respirable material released to the environment $(\mathrm{L})$

$=M A R \times D R \times A R F \times R F$

$=(208 \mathrm{~L})(1)\left(2 \times 10^{-3}\right)(0.3)$

$=0.125 \mathrm{~L}$

$\chi / Q^{\prime} \quad=$ onsite atmospheric dispersion coefficient

$=3.28 \times 10^{-2} \mathrm{~s} / \mathrm{m}^{3}$

$B R \quad=$ breathing rate

$=3.33 \times 10^{-4} \mathrm{~m}^{3} / \mathrm{s}$

$U L D=$ (onsite ULD before drying) (concentration factor)

$=(1,200 \mathrm{~Sv} / \mathrm{L})(8.1)$

$=9,720 \mathrm{~Sv} / \mathrm{L}$.

The onsite dose for free-fall spills is:

$$
D_{\text {spill }}=(0.125 \mathrm{~L})\left(3.28 \times 10^{-2} \mathrm{~s} / \mathrm{m}^{3}\right)\left(3.33 \times 10^{-4} \mathrm{~m}^{3} / \mathrm{s}\right)(9,720 \mathrm{~Sv} / \mathrm{L})=0.013 \mathrm{~Sv}
$$

The onsite dose for entrainment and resuspension can be found similarly using the ARR:

$$
D_{\text {entrainment }}=(Q, \text { released })\left(\chi / Q^{\prime}\right)(B R)(U L D)
$$

where:

$$
\begin{aligned}
Q, \text { released } & =\text { liters of respirable material released to the environment }(\mathrm{L}) \\
& =\text { MAR } \times \text { DR } \times \text { ARR } \times R F \times \text { release time } \\
& =(208 \mathrm{~L})(1)\left(4 \times 10^{-5} \mathrm{~h}^{-1}\right)(1.0)(8 \mathrm{~h}) \\
& =0.066 \mathrm{~L} \\
& =\text { onsite atmospheric dispersion coefficient } \\
& =5.58 \times 10^{-3} \mathrm{~s}^{3} \\
& =\text { breathing } \mathrm{rate}^{3} \\
B R & =3.33 \times 10^{-4} \mathrm{~m}^{3} / \mathrm{s} \\
& =(\text { onsite } \mathrm{ULD} \text { before drying) (concentration factor) } \\
& =(1,200 \mathrm{~Sv} / \mathrm{L})(8.1) \\
& =9,720 \mathrm{~Sv} / \mathrm{L} .
\end{aligned}
$$

The onsite dose due to entrainment is:

$$
D_{\text {entrainment }}=(0.066 \mathrm{~L})\left(5.58 \times 10^{-3} \mathrm{~s} / \mathrm{m}^{3}\right)\left(3.33 \times 10^{-4} \mathrm{~m}^{3} / \mathrm{s}\right)(9,720 \mathrm{~Sv} / \mathrm{L})=1.2 \times 10^{-3} \mathrm{~Sv}
$$

The total onsite dose is the sum of the dose due to the free-fall spill and the entrainment from the unconfined powder:

$$
\begin{gathered}
\text { Dose }=D_{\text {spill }}+D_{\text {entrainment }} \\
\text { Dose }=0.013 \mathrm{~Sv}+1.2 \times 10^{-3} \mathrm{~Sv}=0.014=1.4 \mathrm{rem}
\end{gathered}
$$




\section{RPP-20725 REV 2}

\section{F5.3.2 Toxicological Consequences}

\section{F5.3.2.1 Onsite Toxicological Consequences}

As stated in Section F3.1 the toxicological consequences for a free-fall spill of cohesionless powder are calculated per the methodology established in RPP-13482. The onsite toxicological consequences are determined by Equation F-2:

$$
\text { Consequence }_{\text {spill }}=\left(Q^{\prime} t\right)\left(\chi / Q^{\prime}\right)(\text { SOF Multiplier })
$$

where:

$$
\begin{aligned}
\text { Consequence } & =\text { final sum of fractions value, unitless } \\
Q / t & =\text { rate of release to the environment }\left(\mathrm{m}^{3} / \mathrm{s}\right) \\
& =(M A R \times D R \times A R F) / t \\
& =(208 \mathrm{~L})(1)\left(2 \times 10^{-3}\right) / 60 \mathrm{~s} \\
& =6.9 \times 10^{-3} \mathrm{~L} / \mathrm{s}=6.9 \times 10^{-6} \mathrm{~m}^{3} / \mathrm{s} \\
& =\text { onsite atmospheric dispersion coefficient } \\
& =3.28 \times 10^{-2} \mathrm{~s}^{3} \mathrm{~m}^{3} \\
\chi / Q^{\prime} & \text { sum-of-fractions multiplier, unitless } \\
\text { SOF Multiplier } & =\text { (TEEL-2 SOF })=5.60 \times 10^{8} \\
& =(\text { TEEL-3 SOF })=3.39 \times 10^{8} .
\end{aligned}
$$

The onsite moderate toxicological consequence for a spill (based on TEEL-2) is:

$$
\text { Consequence }=\left(6.9 \times 10^{-6} \mathrm{~m}^{3} / \mathrm{s}\right)\left(3.28 \times 10^{-2} \mathrm{~s} / \mathrm{m}^{3}\right)\left(5.60 \times 10^{8}\right)=130
$$

The onsite high toxicological consequence for a spill (based on TEEL-3) is:

$$
\text { Consequence }=\left(6.9 \times 10^{-6} \mathrm{~m}^{3} / \mathrm{s}\right)\left(3.28 \times 10^{-2} \mathrm{~s} / \mathrm{m}^{3}\right)\left(3.39 \times 10^{8}\right)=77
$$

The onsite consequence for entrainment and resuspension can be found similarly using the ARR:

$$
\text { Consequence }_{\text {entrainment }}=(Q / t)\left(\chi / Q^{\prime}\right)(\text { SOF Multiplier })
$$

where:

$$
\begin{aligned}
& \text { Consequence }=\text { final sum of fractions value, unitless } \\
& Q / t \quad=\text { rate of release to the environment }\left(\mathrm{m}^{3} / \mathrm{s}\right) \\
& =M A R \times D R \times A R R \times \text { conversion factor } \\
& =(208 \mathrm{~L})(1)\left(4 \times 10^{-5} \mathrm{hr}^{-1}\right)(1 \mathrm{hr} / 3,600 \mathrm{~s}) \\
& =2.3 \times 10^{-6} \mathrm{~L} / \mathrm{s}=2.3 \times 10^{-9} \mathrm{~m}^{3} / \mathrm{s} \\
& \chi / Q^{\prime} \quad=\text { onsite atmospheric dispersion coefficient } \\
& =3.28 \times 10^{-2} \mathrm{~s} / \mathrm{m}^{3} \\
& \text { SOF Multiplier }=\text { sum-of-fractions multiplier, unitless } \\
& =(\text { TEEL-2 SOF })=5.60 \times 10^{8} \\
& =(\text { TEEL-3 SOF })=3.39 \times 10^{8} \text {. }
\end{aligned}
$$




\section{RPP-20725 REV 2}

The onsite moderate toxicological consequence for entrainment (based on TEEL-2) is:

$$
\text { Consequence }=\left(2.3 \times 10^{-9} \mathrm{~m}^{3} / \mathrm{s}\right)\left(3.28 \times 10^{-2} \mathrm{~s} / \mathrm{m}^{3}\right)\left(5.60 \times 10^{8}\right)=0.042
$$

The onsite high toxicological consequence for entrainment (based on TEEL-3) is:

$$
\text { Consequence }=\left(2.3 \times 10^{-9} \mathrm{~m}^{3} / \mathrm{s}\right)\left(3.28 \times 10^{-2} \mathrm{~s} / \mathrm{m}^{3}\right)\left(3.39 \times 10^{8}\right)=0.026
$$

The overall onsite toxicological consequences can be found by summing the contribution of the free-fall spill with the subsequent entrainment and resuspension.

The total onsite moderate toxicological consequence (based on TEEL-2) is:

$$
\text { Consequence }=130+0.042=130
$$

The total onsite high toxicological consequence (based on TEEL-3) is:

$$
\text { Consequence }=77+0.026=77
$$

\section{F5.3.2.2 Offsite Toxicological Consequences}

The offsite toxicological consequences are determined similarly:

$$
\text { Consequence }=(Q / t)\left(\chi / Q^{\prime}\right)(S O F \text { Multiplier })
$$

where:

$$
\begin{aligned}
\text { Consequence } & =\text { final sum of fractions value, unitless } \\
Q / t & =\text { rate of release to the environment }\left(\mathrm{m}^{3} / \mathrm{s}\right) \\
& =(M A R \times D R \times A R F) / t \\
& =(208 \mathrm{~L})(1)\left(2 \times 10^{-3}\right) / 60 \mathrm{~s} \\
& =6.9 \times 10^{-3} \mathrm{~L} / \mathrm{s}=6.9 \times 10^{-6} \mathrm{~m}^{3} / \mathrm{s} \\
& =\text { offsite atmospheric dispersion coefficient } \\
& =2.22 \times 10^{-5} \mathrm{~s} / \mathrm{m}^{3} \\
\chi / Q^{\prime} & \\
\text { SOF Multiplier } & =\text { sum-of-fractions multiplier, unitless } \\
& =(\text { TEEL-1 SOF })=1.71 \times 10^{9} \\
& =(\text { TEEL-2 SOF })=5.60 \times 10^{8} .
\end{aligned}
$$

The offsite moderate toxicological consequence for a spill (based on TEEL-1) is:

$$
\text { Consequence }=\left(6.9 \times 10^{-6} \mathrm{~m}^{3} / \mathrm{s}\right)\left(2.22 \times 10^{-5} \mathrm{~s} / \mathrm{m}^{3}\right)\left(1.71 \times 10^{9}\right)=0.26
$$

The offsite consequence for entrainment and resuspension can be found similarly using the ARR:

$$
\text { Consequence }_{\text {entrainment }}=(Q / t)\left(\chi / Q^{\prime}\right)(S O F \text { Multiplier })
$$




\section{RPP-20725 REV 2}

where:

$$
\begin{aligned}
\text { Consequence } & =\text { final sum of fractions value, unitless } \\
Q / t & =\text { release to the environment }\left(\mathrm{m}^{3} / \mathrm{s}\right) \\
& =\text { MAR } \times \text { DR } \times \text { ARR } \times \text { conversion factor } \\
& =(208 \mathrm{~L})(1)\left(4 \times 10^{-5} \mathrm{hr}^{-1}\right)(1 \mathrm{hr} / 3,600 \mathrm{~s}) \\
& =2.3 \times 10^{-6} \mathrm{~L} / \mathrm{s}=2.3 \times 10^{-9} \mathrm{~m}^{3} / \mathrm{s} \\
& =\text { offsite atmospheric dispersion coefficient } \\
& =2.22 \times 10^{-5} \mathrm{~s} / \mathrm{m}^{3} \\
\chi / Q^{\prime} & \text { sum-of-fractions multiplier, unitless } \\
\text { SOF Multiplier } & =(\text { TEEL-1 SOF })=1.71 \times 10^{9} \\
& =(\text { TEEL-2 SOF })=5.60 \times 10^{8} .
\end{aligned}
$$

The offsite moderate toxicological consequence for entrainment (based on TEEL-1) is:

$$
\text { Consequence }=\left(2.3 \times 10^{-9} \mathrm{~m}^{3} / \mathrm{s}\right)\left(2.22 \times 10^{-5} \mathrm{~s} / \mathrm{m}^{3}\right)\left(1.71 \times 10^{9}\right)=8.8 \times 10^{-5}
$$

The overall offsite toxicological consequences can be found by summing the contribution of the free-fall spill with the subsequent entrainment and resuspension.

The total offsite moderate toxicological consequence (based on TEEL-1) is:

$$
\text { Consequence }=0.26+8.8 \times 10^{-5}=0.26
$$

\section{F5.4 Filtration Failures}

Filtration failure scenarios considered are:

- High-efficiency particulate air (HEPA) filter failure due to high temperature

- HEPA filter failure due to high pressure

- Leakage around HEPA filters due to maintenance failure, misaligned filter, or damage to ductwork.

The following assumptions and input data apply to the filter failure scenarios:

- The exhaust HEPA filter loading for the CH-TRUM Off-Gas Treatment System (OGTS) is $1 \mathrm{~L}$ of dried waste based on filter plugging data. Prefilters are assumed to be loaded with $10 \%$ of the maximum waste on a HEPA filter.

- Both first and second stage HEPA filters, prefilters, and the activated carbon filter are assumed to have a high waste loading and are assumed to be involved in a filter failure accident. 


\section{RPP-20725 REV 2}

- For purposes of estimating toxicological release rates, the filter releases from the over pressure event are assumed to be complete in less than $1 \mathrm{~min}$.

- For purposes of estimating toxicological release rates, the filter releases from the over temperature event are assumed to occur over a period of $15 \mathrm{~min}$.

- Release fractions from HEPA filters failed by over pressure or high temperature events are $2 \times 10^{-6}$ and $1 \times 10^{-4}$, respectively as recommended in DOE-HDBK-3010-94.

\section{F5.4.1 Eight-Hour Unfiltered Release}

The dust generated by the process is assumed to be equal to the nominal throughput rate given as $4.2 \times 10^{-3} \mathrm{~kg} / \mathrm{h}$ of dried sludge with a bulk density of $2.0 \mathrm{~kg} / \mathrm{L}$. On a volumetric basis the dust flow rate is then $0.0021 \mathrm{~L} / \mathrm{h}$ or $5.8 \times 10^{-10} \mathrm{~m}^{3} / \mathrm{s}$. The 8 -hr release would then be $0.017 \mathrm{~L}$. For purposes of this analysis it is assumed that the dust flow rate into the filters is proportional to the air flow rate.

\section{F5.4.1.1 Onsite Radiological Consequences}

The resulting radiological dose due to the 8-hr continuous releases from the OGTS with no filtration is shown below.

The onsite dose is found using the methodology in RPP-13482.

$$
D_{\text {onsite }}=(Q, \text { released })\left(\chi / Q_{\text {onsite }}^{\prime}\right)(B R)\left(U L D_{\text {onsite }}\right)
$$

where:

$$
\begin{aligned}
Q, \text { released } & =\text { liters of respirable material released to the environment }(\mathrm{L}) \\
& =0.017 \mathrm{~L} \\
\chi / Q^{\prime}{ }_{\text {onsite }} & =\text { onsite } 8-\mathrm{hr} \text { atmospheric dispersion coefficient } \\
& =5.58 \times 10^{-3} \mathrm{~s} / \mathrm{m}^{3} \\
B R & =\text { breathing rate } \\
& =3.33 \times 10^{-4} \mathrm{~m}^{3} / \mathrm{s} \\
U L D_{\text {onsite }} & =\text { onsite ULD } \\
& =(1,200 \times 8.1) \mathrm{Sv} / \mathrm{L} .
\end{aligned}
$$

The dose is calculated as follows:

$$
0.017 L \times \frac{5.58 \times 10^{-3} s}{m^{3}} \times \frac{3.33 \times 10^{-4} \mathrm{~m}^{3}}{s} \times \frac{1200 \mathrm{~Sv}}{L} \times 8.1 \times \frac{100 \mathrm{rem}}{\mathrm{Sv}}=0.031 \mathrm{rem}
$$


RPP-20725 REV 2

Table F5-3. Radiological Doses Due to 8-Hr Continuous Unfiltered Release.

\begin{tabular}{|c|c|c|c|}
\hline \multirow{3}{*}{ Receptor } & \multicolumn{3}{|c|}{ 8-Hr Release } \\
\hline & \multirow{2}{*}{$\begin{array}{c}\text { Release } \\
\text { (L) }\end{array}$} & \multicolumn{2}{|c|}{ Dose } \\
\hline & & (Sv) & (rem) \\
\hline Onsite & 0.017 & $3.1 \times 10^{-4}$ & 0.031 \\
\hline
\end{tabular}

\section{F5.4.1.2 Toxicological Consequences}

The toxicological consequences are calculated per the methodology established in RPP-13482.

Onsite Consequence $=(Q / t)\left(\chi / Q_{\text {onsite }}^{\prime}\right)($ SOF Multiplier $)$

where:

$$
\begin{aligned}
& \text { Consequence }=\text { final sum of fractions value, unitless } \\
& Q / t \quad=\text { rate of release to the environment, } 5.8 \times 10^{-10} \mathrm{~m}^{3} / \mathrm{s} \\
& \chi / Q^{\prime} \quad=\text { onsite } 1 \text {-hr atmospheric dispersion coefficient } \\
& =3.28 \times 10^{-2} \mathrm{~s} / \mathrm{m}^{3}
\end{aligned}
$$

The onsite moderate toxicological consequence, based on the TEEL-2 SOF multiplier is:

Onsite Consequence $($ moderate $)=\left(5.8 \times 10^{-10} \mathrm{~m}^{3} / \mathrm{s}\right)\left(3.28 \times 10^{-2} \mathrm{~s} / \mathrm{m}^{3}\right)\left(5.6 \times 10^{8}\right)=0.011$ where:

$$
5.6 \times 10^{8}=\text { TEEL-2 SOF multiplier }
$$

The offsite toxicological consequences are determined similarly:

$$
\text { Consequence }=\left(Q^{\prime} t\right)\left(\chi / Q^{\prime}\right)(S O F \text { Multiplier })
$$

where:

$$
\begin{aligned}
& \text { Consequence } \\
& \begin{aligned}
Q / t & \text { final sum of fractions value, unitless } \\
\chi / Q^{\prime} & =\text { rate of release to the environment, } 5.8 \times 10^{-10} \mathrm{~m}^{3} / \mathrm{s} \\
& =2.22 \times 10^{-5} \mathrm{~s} / \mathrm{m}^{3} \\
\text { SOF Multiplier } & =\text { sum-of-fractions multiplier, unitless. }
\end{aligned}
\end{aligned}
$$

The offsite moderate toxicological consequence, based on the TEEL-1 SOF multiplier calculated in Section F6.1, is:

Offsite Consequence $($ moderate $)=\left(5.8 \times 10^{-10} \mathrm{~m}^{3} / \mathrm{s}\right)\left(2.22 \times 10^{-5} \mathrm{~s} / \mathrm{m}^{3}\right)\left(1.7 \times 10^{9}\right)=2.2 \times 10^{-5}$ where: 
$1.7 \times 10^{9}=$ TEEL-1 SOF multiplier

The resulting SOFs for the continuous unfiltered release are shown in Table F5-4.

Table F5-4. Toxicological Sum of Fractions Relative to the Consequence Class Thresholds for a Continuous Unfiltered Release.

\begin{tabular}{|c|c|c|}
\hline Receptor & Release Rate (L/s) & Sum of Fractions \\
\hline Onsite & & 0.011 (moderate) \\
\hline \multirow{2}{*}{ Offsite } & $5.8 \times 10^{-7}$ & $\cdots$ (high) \\
\hline & & $2.2 \times 10^{-5}$ (moderate) \\
\hline
\end{tabular}

\section{F5.4.2 HEPA Filter Failure Due to High Temperature}

The HEPA filter release fraction for the high temperature filter failure scenario is assumed to be $1 \times 10^{-4}$ based on recommendations in Section 5.4.1 of DOE-HDBK-3010-94. This release fraction is assumed to also apply to the prefilter and the material in the upstream filtration system.

\section{F5.4.2.1 Onsite Radiological Consequences}

The onsite dose for the release from the filter due to high temperature is found using the methodology in RPP-13482:

$$
D=(Q, \text { released })\left(\chi^{\prime} Q^{\prime}\right)(B R)(U L D)
$$

where:

$$
\begin{aligned}
Q, \text { released } & =\text { liters of respirable material released to the environment }(\mathrm{L}) \\
& =M A R \times D R \times A R F \times R F \\
& =(5.2 \mathrm{~L})(1)\left(1 \times 10^{-4}\right)(1) \\
& =5.2 \times 10^{-4} \mathrm{~L} \\
& =\text { onsite } 1-\mathrm{hr} \text { atmospheric dispersion coefficient } \\
& =3.28 \times 10^{-2} \mathrm{~s}^{3} \\
& =\text { breathing rate } \\
& =3.33 \times 10^{-4} \mathrm{~m}^{3} / \mathrm{s} \\
& =\text { onsite ULD } \\
& =\text { Sludge ULD } x \text { Concentration Factor } \\
& =(1200 \mathrm{~Sv} / \mathrm{L})(8.1) . \\
U L D \quad & \\
& \\
5.2 \times 10^{-4} L \times & \frac{3.28 \times 10^{-2} s}{m^{3}} \times \frac{3.33 \times 10^{-4} \mathrm{~m}^{3}}{s} \times \frac{1200 \mathrm{~Sv}}{L} \times 8.1 \times \frac{100 \mathrm{rem}}{\mathrm{Sv}}=5.5 \times 10^{-3} \mathrm{rem}
\end{aligned}
$$




\section{RPP-20725 REV 2}

The scenario includes 8-hr unfiltered release through the failed filters. Table F5-3 shows the radiological doses due to the 8 -hr continuous release from the OGTS with no filtration. The total consequence for the filter failure due to high temperature is the sum of the release from the filters and the 8-hr continuous unfiltered release.

$$
D_{\text {total }}=0.031 \mathrm{rem}+5.5 \times 10^{-3} \mathrm{rem}=0.36 \mathrm{rem}
$$

\section{F5.4.2.2 Toxicological Consequences}

In the case of toxicological exposures, the maximum concentration at the receptor is the operative parameter so that the 1-hr $\chi / Q^{\prime}$ (i.e., without plume meander) is used. The release rate $Q^{\prime}$ is given in terms of liters of dried waste released per second averaged over a 15-min release time. The release rate must be divided by $1,000 \mathrm{~L} / \mathrm{m}^{3}$ to make the units compatible with the $\chi / \mathrm{Q}^{\prime}$.

Consistent with previous filtration failure analyses for tank farms facilities, it is assumed that the release from the filter in the high temperature failure scenario requires at least $15 \mathrm{~min}$ so the release is averaged over $900 \mathrm{~s}(15 \mathrm{~min})$. The combined case with both the filter release and the unfiltered release from the OGTS is also shown. It is assumed that both releases occur concurrently and are thus additive.

The onsite toxicological consequences are determined:

$$
\text { Onsite Consequence }=(Q / t)\left(\chi / Q_{\text {onsite }}^{\prime}\right)(S O F \text { Multiplier })
$$

where:

$$
\begin{aligned}
& \text { Consequence }=\text { final sum of fractions value, unitless } \\
& Q / t \quad=\text { rate of release to the environment } \\
& =(5.2 \mathrm{~L})\left(1 \times 10^{-4}\right) /(900 \mathrm{~s})\left(1,000 \mathrm{~L} / \mathrm{m}^{3}\right)=5.8 \times 10^{-10} \mathrm{~m}^{3} / \mathrm{s} \\
& \chi / Q^{\prime} \quad=\text { Onsite } 1-\mathrm{hr} \text { atmospheric dispersion coefficient } \\
& =3.28 \times 10^{-2} \mathrm{~s} / \mathrm{m}^{3}
\end{aligned}
$$

The onsite moderate toxicological consequence, based on the TEEL-2 SOF multiplier is:

$$
\text { Onsite Consequence }(\text { moderate })=\left(5.8 \times 10^{-10} \mathrm{~m}^{3} / \mathrm{s}\right)\left(3.28 \times 10^{-2} \mathrm{~s} / \mathrm{m}^{3}\right)\left(5.6 \times 10^{8}\right)=0.011
$$

where:

$$
5.6 \times 10^{8}=\text { TEEL-2 SOF multiplier }
$$

It is assumed that both releases occur concurrently and are thus additive. The combined onsite moderate toxicological consequence, based on the TEEL-2 SOF multiplier, from the hightemperature filter failure and the 8 -hr continuous unfiltered release is:

$$
\text { Combined Onsite Consequence }(\text { moderate })=0.011+0.011=0.022
$$


The offsite toxicological consequences are determined similarly:

$$
\text { Consequence }=(Q / t)\left(\chi / Q^{\prime}\right)(S O F \text { Multiplier })
$$

where:

$$
\begin{aligned}
& \text { Consequence }=\text { final sum of fractions value, unitless } \\
& Q / t=\text { rate of release to the environment, } 5.8 \times 10^{-10} \mathrm{~m}^{3} / \mathrm{s} \\
& \chi^{\prime} Q^{\prime} \quad=\text { offsite } 1-\mathrm{hr} \text { atmospheric dispersion coefficient } \\
& =2.22 \times 10^{-5} \mathrm{~s} / \mathrm{m}^{3}
\end{aligned}
$$

The offsite moderate toxicological consequence, based on the TEEL-1 SOF multiplier is:

Offsite Consequence $($ moderate $)=\left(5.8 \times 10^{-10} \mathrm{~m}^{3} / \mathrm{s}\right)\left(2.22 \times 10^{-5} \mathrm{~s} / \mathrm{m}^{3}\right)\left(1.7 \times 10^{9}\right)=2.2 \times 10^{-5}$

where:

$$
1.7 \times 10^{9}=\text { TEEL-1 SOF multiplier }
$$

It is assumed that both releases occur concurrently and are thus additive. The combined onsite moderate toxicological consequence, based on the TEEL-2 SOF multiplier, from the hightemperature filter failure and the 8-hr continuous unfiltered release is:

$$
\text { Combined Offsite Consequence }(\text { moderate })=2.2 \times 10^{-5}+2.2 \times 10^{-5}=4.4 \times 10^{-5}
$$

\section{F5.4.3 HEPA Filter Failure Due to High Pressure}

The filter release fraction for the high pressure failure scenario is assumed to be $2 \times 10^{-6}$ based on recommendations in Section 5.4.2.1 of DOE-HDBK-3010-94. This release fraction is assumed to also apply to the prefilter and the material in the upstream filtration system.

\section{F5.4.3.1 Onsite Radiological Consequences}

The onsite dose for the release from the filter due to high pressure is found using the methodology in RPP-13482:

$$
D=(Q, \text { released })\left(\chi / Q^{\prime}\right)(B R)(U L D)
$$

where:

$$
\begin{aligned}
Q, \text { released } & =\text { liters of respirable material released to the environment }(\mathrm{L}) \\
& =M A R \times D R \times A R F \times R F \\
& =(5.2 \mathrm{~L})(1)\left(2 \times 10^{-6}\right)(1) \\
& =1.0 \times 10^{-5} \mathrm{~L} \\
& =\text { onsite } 1-\mathrm{hr} \text { atmospheric dispersion coefficient } \\
& =3.28 \times 10^{-2} \mathrm{~s} / \mathrm{m}^{3} \\
& =\text { breathing rate } \\
& =3.33 \times 10^{-4} \mathrm{~m}^{3} / \mathrm{s} \\
B R \quad &
\end{aligned}
$$




\section{RPP-20725 REV 2}

$$
\begin{aligned}
& U L D=\text { onsite ULD } \\
&=\text { Sludge ULD } x \text { Concentration factor } \\
&=(1,200 \mathrm{~Sv} / \mathrm{L})(8.1) . \\
& 1.0 \times 10^{-5} L \times \frac{3.28 \times 10^{-2} s}{\mathrm{~m}^{3}} \times \frac{3.33 \times 10^{-4} \mathrm{~m}^{3}}{s} \times \frac{1200 \mathrm{~Sv}}{L} \times 8.1 \times \frac{100 \mathrm{rem}}{\mathrm{Sv}}=1.1 \times 10^{-4} \mathrm{rem}
\end{aligned}
$$

The scenario includes $8 \mathrm{hr}$ unfiltered release through the failed filters. Table F5-3 shows the radiological doses due to the 8 -hr continuous release from the OGTS with no filtration. The total consequence for the filter failure due to high temperature is the sum of the release from the filters and the 8-hr continuous unfiltered release.

$$
\mathrm{D}_{\text {total }}=0.031 \mathrm{rem}+1.1 \times 10^{-4} \mathrm{rem}=0.031 \mathrm{rem}
$$

\section{F5.4.3.2 Toxicological Consequences}

Consistent with previous filtration failure analyses for tank farms facilities, it is assumed that the release from the filter in the high pressure failure scenario requires less than 1 min so the release is averaged over $60 \mathrm{~s}(1 \mathrm{~min})$. It is assumed that the release from the filters and the $8-\mathrm{hr}$ unfiltered release occur concurrently and are thus additive.

The onsite toxicological consequences are determined:

$$
\text { Onsite Consequence }=\left(Q^{\prime} t\right)\left(\chi^{\prime} Q_{\text {onsite }}^{\prime}\right)(\text { SOF Multiplier })
$$

where:

$$
\begin{aligned}
& \text { Consequence }=\text { final sum of fractions value, unitless } \\
& Q / t \quad=\text { rate of release to the environment } \\
& =(5.2 \mathrm{~L})\left(2 \times 10^{-6}\right) /(60 \mathrm{~s})\left(1,000 \mathrm{~L} / \mathrm{m}^{3}\right)=1.7 \times 10^{-10} \mathrm{~m}^{3} / \mathrm{s} \\
& \chi / Q^{\prime} \quad=\text { onsite } 1-\mathrm{hr} \text { atmospheric dispersion coefficient } \\
& =3.28 \times 10^{-2} \mathrm{~s} / \mathrm{m}^{3} \\
& \text { SOF Multiplier }=\text { sum-of-fractions multiplier, unitless. }
\end{aligned}
$$

The onsite moderate toxicological consequence, based on the TEEL-2 SOF multiplier is:

$$
\text { Onsite Consequence }(\text { moderate })=\left(1.7 \times 10^{-10} \mathrm{~m}^{3} / \mathrm{s}\right)\left(3.28 \times 10^{-2} \mathrm{~s} / \mathrm{m}^{3}\right)\left(5.6 \times 10^{8}\right)=3.1 \times 10^{-3}
$$

where:

$$
5.6 \times 10^{8}=\text { TEEL-2 SOF multiplier }
$$

It is assumed that both releases occur concurrently and are thus additive. The combined onsite moderate toxicological consequence, based on the TEEL-2 SOF multiplier, from the highpressure filter failure and the 8-hr continuous unfiltered release is:

$$
\text { Combined Onsite Consequence(moderate })=0.011+3.1 \times 10^{-3}=0.014
$$


The offsite toxicological consequences are determined similarly:

$$
\text { Consequence }=(Q / t)\left(\chi / Q^{\prime}\right)(\text { SOF Multiplier })
$$

where:

$$
\begin{array}{ll}
\text { Consequence } & =\text { final sum of fractions value, unitless } \\
Q^{/ t} & =\text { rate of release to the environment, } 1.7 \times 10^{-10} \mathrm{~m}^{3} / \mathrm{s} \\
\chi / Q^{\prime} & =\text { offsite } 1-\mathrm{hr} \text { atmospheric dispersion coefficient } \\
& =2.22 \times 10^{-5} \mathrm{~s} / \mathrm{m}^{3}
\end{array}
$$

SOF Multiplier $=$ sum-of-fractions multiplier, unitless.

The offsite moderate toxicological consequence, based on the TEEL-1 SOF multiplier is:

Offsite Consequence $($ moderate $)=\left(1.7 \times 10^{-10} \mathrm{~m}^{3} / \mathrm{s}\right)\left(2.22 \times 10^{-5} \mathrm{~s} / \mathrm{m}^{3}\right)\left(1.7 \times 10^{9}\right)=6.4 \times 10^{-6}$

where:

$$
1.1 \times 10^{9}=\text { TEEL-1 SOF multiplier }
$$

It is assumed that both releases occur concurrently and are thus additive. The combined onsite moderate toxicological consequence, based on the TEEL-2 SOF multiplier, from the highpressure filter failure and the 8-hr continuous unfiltered release is:

$$
\text { Combined Offsite Consequence }(\text { moderate })=2.2 \times 10^{-5}+6.4 \times 10^{-6}=2.8 \times 10^{-5}
$$

\section{F6.0 RESULTS}

Tables F6-1 and F6-2 compare the accident consequences with the risk evaluation guidelines. Reviewing the consequences shows that the release of dry radioactive waste materials representative accident is above the onsite radiological guidelines for high consequences. Both onsite and offsite toxicological consequences are also above their respective high consequence guideline.

Table F6-1. Summary of Onsite Radiological Consequences Without Controls for the Release of Dry Radioactive Waste Materials Accidents.

\begin{tabular}{|l|c|c|c|}
\hline \multirow{2}{*}{ Case } & \multicolumn{2}{|c|}{ Onsite radiological consequences } \\
\cline { 2 - 4 } & $\begin{array}{c}\text { Calculated dose } \\
\text { (rem) }\end{array}$ & $\begin{array}{c}\text { Moderate } \\
\text { consequence } \\
\text { guideline } \\
\text { (rem) }\end{array}$ & $\begin{array}{c}\text { High consequence } \\
\text { guideline } \\
\text { (rem) }\end{array}$ \\
\hline $\begin{array}{l}\text { Dried waste spill from greater than } \\
3 \mathrm{~m}\end{array}$ & 1,300 & 25 & 100 \\
\hline $\begin{array}{l}\text { Dried waste spill from less than } \\
3 \mathrm{~m} \text { (dryer contents) }\end{array}$ & 42 & 25 & 100 \\
\hline Spill of a single drum & 1.4 & 25 & 100 \\
\hline
\end{tabular}


Table F6-2. Summary of Toxicological Consequences Without Controls for the Release of Dry Radioactive Waste Materials Accidents.

\begin{tabular}{|c|c|c|c|c|c|c|c|c|}
\hline \multirow{4}{*}{ Case } & \multicolumn{8}{|c|}{ Toxicological consequences } \\
\hline & \multicolumn{4}{|c|}{ Onsite } & \multicolumn{4}{|c|}{ Offsite } \\
\hline & \multicolumn{2}{|c|}{$\begin{array}{l}\text { Moderate } \\
\text { consequence }\end{array}$} & \multicolumn{2}{|c|}{$\begin{array}{c}\text { High } \\
\text { consequence }\end{array}$} & \multicolumn{2}{|c|}{$\begin{array}{l}\text { Moderate } \\
\text { consequence }\end{array}$} & \multicolumn{2}{|c|}{$\begin{array}{c}\text { High } \\
\text { consequence }\end{array}$} \\
\hline & SOF & Guideline & SOF & Guideline & SOF & Guideline & SOF & Guideline \\
\hline $\begin{array}{l}\text { Dried waste spill from } \\
\text { greater than } 3 \mathrm{~m}\end{array}$ & 3,800 & 1 & 2,300 & 1 & 7.9 & 1 & 2.6 & 1 \\
\hline $\begin{array}{l}\text { Dried waste spill from } \\
\text { less than } 3 \mathrm{~m} \text { (dryer } \\
\text { contents) }\end{array}$ & 380 & 1 & 230 & 1 & 0.78 & 1 & $\cdots$ & 1 \\
\hline Spill of a single drum & 130 & 1 & 77 & 1 & 0.26 & 1 & --- & 1 \\
\hline
\end{tabular}

Note:

SOF $=$ sum of fractions.

The applicable consequences of the filtration system failure scenarios for the CH-TRUM WPU with no credit for the OGTS are summarized in Table F6-3.

Table F6-3. Summary of Consequences of Ventilation System Failure Accidents for the Contact-Handled Transuranic Mixed Waste Packaging Unit.

\begin{tabular}{|c|c|c|c|}
\hline Scenario & Exposure Type & Onsite Receptor & Offsite Receptor \\
\hline \multirow{3}{*}{$\begin{array}{l}\text { High Temperature Filter } \\
\text { failure (including } \\
\text { unfiltered release) }\end{array}$} & Radiological Dose (rem) & 0.037 & $\mathrm{NA}$ \\
\hline & $\begin{array}{c}\text { Toxicological SOF } \\
\text { (moderate) }\end{array}$ & 0.022 & $4.4 \times 10^{-5}$ \\
\hline & $\begin{array}{c}\text { Toxicological SOF } \\
\text { (high) }\end{array}$ & --- & $\cdots$ \\
\hline \multirow{3}{*}{$\begin{array}{l}\text { High Pressure Filter } \\
\text { Failure (including } \\
\text { unfiltered release) }\end{array}$} & Radiological Dose (rem) & 0.031 & NA \\
\hline & $\begin{array}{c}\text { Toxicological SOF } \\
\text { (moderate) }\end{array}$ & 0.014 & $2.8 \times 10^{-5}$ \\
\hline & $\begin{array}{c}\text { Toxicological SOF } \\
\text { (high) }\end{array}$ & --- & --- \\
\hline \multirow{3}{*}{$\begin{array}{l}\text { Continuous Unfiltered } \\
\text { Release (no filter failure) }\end{array}$} & Radiological Dose (rem) & 0.031 & NA \\
\hline & $\begin{array}{c}\text { Toxicological SOF } \\
\text { (moderate) }\end{array}$ & 0.011 & $2.2 \times 10^{-5}$ \\
\hline & $\begin{array}{c}\text { Toxicological SOF } \\
\text { (high) }\end{array}$ & -- & -- \\
\hline
\end{tabular}

Notes:

NA = not applicable for this analysis.

SOF $=$ sum of fractions relative to moderate consequences.

The results in Table F6-3 show that the OGTS filtration failure scenarios result in low consequence radiological and toxicological exposure for all scenarios and all receptors. 


\section{F7.0 REFERENCES}

DOE-HDBK-3010-94, 2000, Airborne Release Fractions/Rates and Respirable Fractions for Nonreactor Nuclear Facilities, Change Notice No. 1, U.S. Department of Energy, Washington, D.C.

Gregory, W. S., R. A. Martin, T. R. Smith and D. E. Fenton, 1982, Response of HEPA Filters to Simulated Accident Conditions, Proceedings of the $17^{\text {th }}$ DOE Nuclear Air Cleaning Conference held in Denver, Colorado, 2-5 August 1982, CONF-820833, Volume 2.

RPP-5924, 2005, Radiological Source Terms for Tank Farms Safety Analysis, Rev. 4, CH2M HILL Hanford Group, Inc., Richland, Washington.

RPP-8369, 2003, Chemical Source Terms for Tank Farms Safety Analyses, Rev. 2, CH2M HILL Hanford Group, Inc., Richland, Washington.

RPP-13482, 2005, Atmospheric Dispersion Coefficients and Radiological/Toxicological Exposure Methodology for Use in Tank Farms, Rev. 4, CH2M HILL Hanford Group, Inc., Richland, Washington.

Weast, R. C., 1981, CRC Handbook of Chemistry and Physics, $61^{\text {st }}$ Ed., CRC Press, Inc., Boca Raton, Florida. 
RPP-20725 REV 2

APPENDIX G

HUMAN FACTORS EVALUATION AND PEER REVIEW CHECKLISTS FOR THE CONTACT-HANDLED TRANSURANIC MIXED WASTE PACKAGING UNIT 
RPP-20725 REV 2

This page intentionally left blank.

G-ii 


\section{APPENDIX G}

\section{HUMAN FACTORS EVALUATION AND PEER REVIEW CHECKLISTS FOR THE CONTACT-HANDLED TRANSURANIC MIXED WASTE PACKAGING UNIT}

Human Factors Evahuation Checklist.

Hazard Analysis Title:

Documented Safety Analysis Section Number:
CH-TRUM Accidents

Chapter 3 of the Contact-Handled Transuranic Mixed Waste Processing Unit Preliminary Documented Safety Analysis

\begin{tabular}{|c|c|c|}
\hline $\begin{array}{l}\text { Item } \\
\text { No. }\end{array}$ & Issue & $\begin{array}{l}\text { Yes, No, } \\
\text { Unknown }\end{array}$ \\
\hline 1 & $\begin{array}{l}\text { Does the activity/event being planned/analyzed require human interaction to } \\
\text { successfully complete the activity or mitigate consequences of the event? } \\
\text { If the answer is No, go to Item No. 23. Otherwise continue with Item No. } 2 \text {. }\end{array}$ & No ${ }^{1}$ \\
\hline 2 & Are procedures/instructions available to the individuals responsible for the action? & \\
\hline 3 & Are procedures/instructions complete, accurate, and validated? & \\
\hline 4 & Are the individuals responsible for the action also responsible for collateral duties? & \\
\hline 5 & Are staffing levels adequate to perform the activity? & \\
\hline 6 & $\begin{array}{l}\text { Are the individuals responsible for the action adequately trained, qualified, and } \\
\text { experienced to perform the actions? }\end{array}$ & \\
\hline 7 & $\begin{array}{l}\text { Have the required actions been walked down in the field to verify execution within the } \\
\text { time constraints identified in the hazard analysis? }\end{array}$ & \\
\hline 8 & $\begin{array}{l}\text { Have physical obstacles that could prevent successful completion of the activity been } \\
\text { removed or accounted for? }\end{array}$ & \\
\hline 9 & Have work area environmental concerns been identified and accounted for? & \\
\hline 10 & Has PPE been dedicated and is available, if required? & \\
\hline 11 & Have the appropriate tools been dedicated and are available, if required? & \\
\hline 12 & Does workstation configuration facilitate completion of the actions? & \\
\hline 13 & Are instruments, valves, switches, or other devices accessible? & \\
\hline 14 & Are instruments, valves, switches, or other devices properly tagged or labeled? & \\
\hline 15 & Is communication equipment operable, dedicated, and available, if necessary? & \\
\hline 16 & Is adequate fixed lighting in place? & \\
\hline 17 & Is portable lighting dedicated, functional, and available, if necessary? & \\
\hline 18 & Are confined space restrictions adequately addressed? & \\
\hline 19 & $\begin{array}{l}\text { Is temperanure, humidity, radiological, and toxicological conditions acceptable for } \\
\text { human occupancy? }\end{array}$ & \\
\hline 20 & $\begin{array}{l}\text { Is hazard material or radiological monitoring equipment dedicated, functional, and } \\
\text { available, if needed? }\end{array}$ & \\
\hline 21 & Are access controls identified and keys available? & \\
\hline 22 & Can activities be completed within the time prescribed in the hazard analysis? & \\
\hline \multicolumn{3}{|c|}{$\begin{array}{l}\text { If any answer for Items } 2 \text { through } 22 \text { is No or Unknown, corrective actions may be required to ensure } \\
\text { successful completion of the activity as described in the hazard analysis. Complete and document corrective } \\
\text { actions on Documented Safety Analysis Implementation Checklist and go to ftem No. } 23 \text {. }\end{array}$} \\
\hline \multirow{3}{*}{23} & Evaluator: $\frac{\text { Marvanne Kummerer }}{\text { Print }}$ & $\frac{-5-05}{\text { Date }}$ \\
\hline & Peer Reviewer: & \\
\hline & Print & Date \\
\hline
\end{tabular}

'No new or specific Technical Safety Requirements (excluding Safety Management Programs) have been allocated for the activities being analyzed. In other words, no specific operator actions are credited in the control allocation. Required activities and necessary training and qualification requirements will be defined by the Safery Management Programs. 
NS\&L CHECKLIST FOR TECHNICAL PEER REVIEW

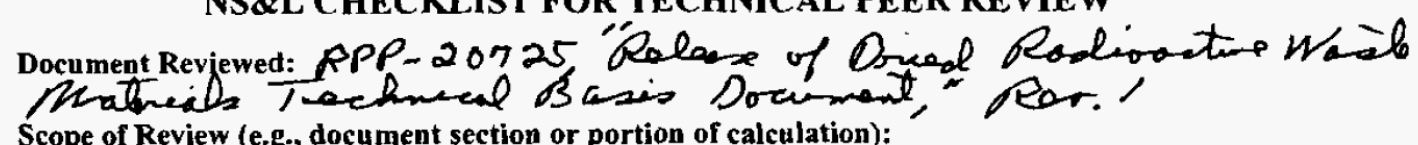

Scope of Review (e.g., document section or portion of calculation):

\section{Yes No NA}

प $\square \square$

Q $\square \square$ 3. Accident scen

Q $\square \square$ 4. Analytical and technical approaches and results are reasonable and appropriate.

(ORP OAPP criterion 2.8) *Explanation:

$\bigotimes \square \square 5$. Necessary assumptions are reasonable, explicitly stated, and supported. (ORP QAPP criterion 2.2) "Explanation:

A $\square \square$ 6. Computer codes and data files are documented.

7. Explanation:

X $\square \square$ 7. Data used in calculations are explicitly stated.

8. Explonoton:

W $\square \square \quad$ 8. Bases for calculations, including assumptions and data, are consistent with the supported safety basis document (e.g., the Tank Farms Documented Safety Analysis). "Explanation:

X $\square \square$ 9. Data were checked for consistency with original source information as applicable. (ORP QAPP criterion 2.9) *Explanation:

$\square \square \square$ 10. For both qualitative and quantitative data, uncertainties are recognized and discussed, as appropriate. (ORP QAPP criterion 2.17)

囚 $\square \square$ 11. Mathematical derivations were checked including dimensional consistency of results. (ORP QAPP criterion 2.16)

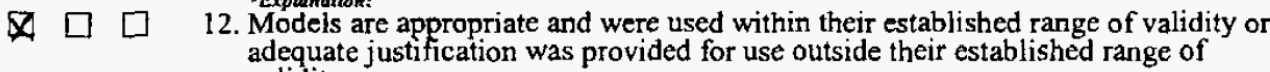
validity. "Explanation:

\ $\square \square \quad$ 13. Spreadsheet results and all hand calculations were verified.

14. Explanation:

(4) $\square \square$ 14. Calculations are sufficiently detailed such that a technically qualified person can understand the analysis without requiring outside information. (ORP OAPP criterion 2.5) *Expianation:

Q $\square \square$ 15. Software input is correct and consistent with the document reviewed.

"Explanation:

$\varnothing \square \square$

Software output is consistent with the input and with the results reported in the document reviewed. "Explanation:

17. Software verification and validation are addressed adequately. (ORP QAPP criterion 2.6) Explanation:

区

18. Limits/criteria/guideline referenced. Limits/criteria/guidelines were checked against references. $(O R P$ QAPP criterion 2.9) *Explanation:

X]

19. Safety margins are consistent with good engineering practices. Explanation:

\ $\square \square \quad 20$. Conclusions are consistent with analytical results and applicable limits. Explanation:

$\forall \square \square \quad 21$. Results and conclusions address all points in the purpose. (ORP QAPP criterion

(8) $\square \square] 22$. All references cited in the text, figures, and tables are contained in the reference list. *Explanation:

$\square \square$ 23. Reference citations (e.g., title and number) are consistent between the text callout and the reference list.

*Explanation:

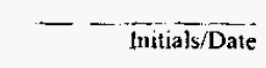

Form Current fo $12 / 0 \times / 2004$ 


\section{RPP-20725 REV 2}

\section{NS\&L CHECKUIST FOR TECHNICAL PEER REVIEW}

Yes $\mathrm{No}^{*} \mathrm{NA}^{*}$

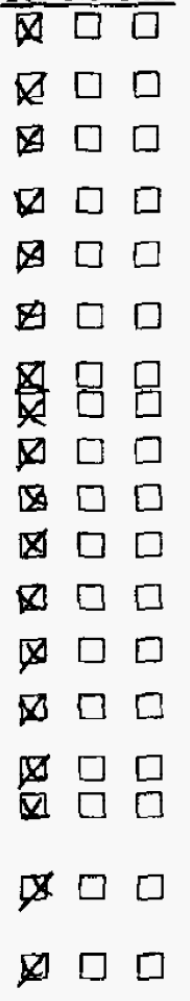

$\$$

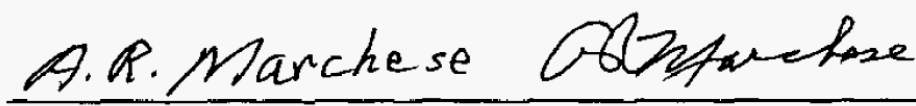

Reviewer (Printed Name and Signature)

Explanation:

25. Referenced documents are retrievable or otherwise available.

Explamation: criterion 2.1) Explanation:

27. There are no duplicate citations in the reference list.

Explanation: cited. "Explanation:

29. All acronyms are spelled out the first time they are used. Explanation:

30. The Table of Contents is correct. *Explanation:

31. All figure, table, and section callouts are correct.

Explanation:

32. Unit conversions are correct and consistent.

33. The number of significant digits is appropriate and consistent.

34. Chemical reactions are correct and balanced. "Explanation:

35. All tables are formatted consistently and are free of blank cells. Explanation: order. *Explanation: was checked for typographical errors. *Explanation:

38. The tables are internally consistent. Explanation:

39. The document was prepared in accordance with HNF-2353, Section 4.3 Attachment B, "Calculation Note Format and Preparation Instructions." *Explanation: Engineering Change Notice (form A-6003-563.1). consistent and complete. Explanation:

Concurrence

24. Only released (i.e., not draft) references are cited. (ORP QAPP criterion 2.1)

The most recent version of each reference is cited, as appropriate. (ORP QAPP

8. Referenced documents are spelled out (title and number) the first time they are

36. The document is complete (pages, attachments, and appendices) and in the proper

37. The document is free of typographical errors. Only the section(s) being reviewed

40. Impacted documents are appropriately identified in Blocks 7 and 25 of the

41. If more than one Technical Peer Reviewer was designated for this document, an overall review of the entire document was performed after resolution of all Technical Peer Review comments and confirmed that the document is self-

, an explanation must be provided on this form.

If No is chosen, an explanation: 


\section{RPP-20725 REV 2}

This page intentionally left blank.

G-4 